\title{
SIMULAÇÃO DE SELEÇÃO RECORRENTE ASSISTIDA POR MARCADORES MOLECULARES EM ESPÉCIES AUTÓGAMAS
}

\section{EDUARDO BEARZOTI}

\author{
Engenheiro Agrônomo
}

Orientador: Prof. Dr. ROLAND VENCOVSKY

Tese apresentada à Escola Superior de Agricultura "Luiz de Queiroz", Universidade de São Paulo, para obtenção do título de Doutor em Agronomia, Área de Concentraçāo: Genética e Melhoramento de Plantas

\author{
PIRACICABA \\ Estado de São Paulo - Brasil \\ Outubro - 1997
}


Dados Intemacionais de Catalogação na Publicação (CIP)

DIVISĀO DE BIBLIOTECA E DOCUMENTAÇĀO - Campus "Luiz de Queiroz"/USP

\section{Bearzoti, Eduardo}

Simulação de seleção recorrente assistida por marcadores moleculares em espécies autógamas / Eduardo Bearzoti. - - Piracicaba, 1997

230p. : il

Tese (doutorado) - Escola Superior de Agricultura Luiz de Queiroz, 1997

Bibliografia.

1. Marcador molecular 2. Melhoramento genético vegetal 3. Seleção recorrente 4. Simulação l. Titulo 
ERRATA

Pg. Expressão

Correção

30

30

(2.6)

30

30

73

(4.20)

74

74

(4.23)

76

(4.28) $J=\frac{1}{(z-1)^{2}}\left[s-\frac{(t-1) x}{t(r-1)}\right]$

77

(4.29)$$
D F_{3}=\frac{1-3 r+2 r^{2}}{4}
$$

$$
f(A B)_{F 3}=\frac{4-7 r+8 r^{2}-4 r^{3}}{8}
$$

$$
D_{F 4}=\frac{2-7 r+8 r^{2}-4 r^{3}}{8}
$$

$$
\sigma_{M}^{2}=\frac{\beta^{\prime} Z^{\prime}\left(I-1_{n} 1_{n}^{+}\right) Z \beta}{r(t-1)}
$$

$$
f(A B)_{F 2}=\frac{2-3 r+2 r^{2}}{4}
$$

$$
\begin{aligned}
& E[S S P]=\operatorname{Tr}\left[\left(P-P_{1}\right) \mathbf{V}\right]+\beta^{\prime} Z^{\prime}\left(P-P_{1}\right) Z \beta=(t-1)\left(\sigma^{2}+r \sigma_{h}^{2}\right)+\beta^{\prime} Z^{\prime}\left(1-1_{n} 1_{n}^{+}\right) Z \beta \\
& E[S S R]=\operatorname{Tr}\left[\left(P_{R}-P_{1}\right) \mathbf{V}\right]+\beta^{\prime} Z^{\prime}\left(P_{R^{-}} P_{1}\right) Z \beta=k\left(\sigma^{2}+r \sigma_{h}^{2}\right)+\beta^{\prime} Z^{\prime}\left(1-1_{n} 1_{n}^{+}\right) Z \beta \\
& E[S S D]=\operatorname{Tr}\left(\left(P-P_{R}\right) V\right]+\beta^{\prime} Z^{\prime}\left(P-P_{R}\right) Z \beta=(t-k-1)\left(\sigma^{2}+r \sigma_{h}^{2}\right)
\end{aligned}
$$

$$
\sigma_{G}^{2}=\sigma_{h}^{2}+\frac{\beta^{\prime} Z^{\prime}\left(I-1_{n} 1_{n}^{+}\right) Z \beta}{r(t-1)}
$$

$$
\begin{aligned}
& f_{z, s, x}(z, s, x)=\frac{\left\{\frac{z}{z-1}\left[\frac{(t-1)}{t(r-1)} x-s\right]-\frac{k}{(t-k-1)} s\right\}^{\frac{k}{2}-1}}{2^{\frac{t r-1}{2}} \Gamma\left[\frac{t(r-1)}{2}\right] \Gamma\left[\frac{t-k-1}{2}\right] \Gamma\left[\frac{k}{2}\right]} \times \\
& x \frac{(z-1)^{-2} s^{\frac{t-k-1}{2}-1} x^{\frac{t(r-1)}{2}} t}{\sigma^{t(r-1)}\left(\sigma^{2}+r \sigma_{h}^{2}\right)^{\frac{t-k-1}{2}}\left(\sigma^{2}+r \sigma_{h}^{2}+\frac{r(t-1)}{k} \sigma_{M}^{2}\right)^{\frac{k}{2}}}\left[s-\frac{(t-1)}{t(r-1)} x\right] \mid x \\
& x \exp \cdot\left[\frac{z}{(z-1)\left[\frac{(t-1)}{t(r-1)} x-s\right]-\frac{k}{(t-k-1)} s}-\frac{s}{2\left(\sigma^{2}+r \sigma_{h}^{2}\right)}-\frac{x}{2 \sigma^{2}}\right]
\end{aligned}
$$




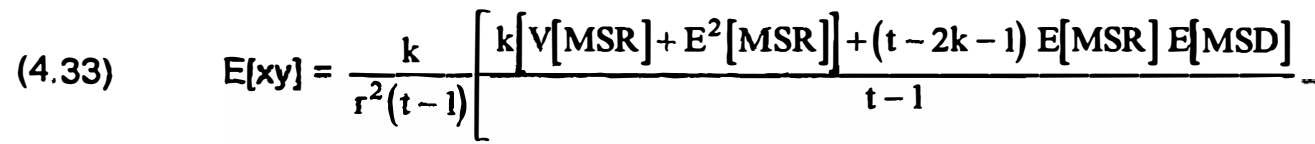

80

$$
\left.\frac{(t-k-1)\left[V[M S D]+E^{2}[M S D]\right.}{(t-1)}-E[M S R] E[M S E]+E[M S D] E[M S E]\right]
$$

84

(4.42)

$$
V[\hat{p}] \cong \frac{2}{\sigma_{G}^{8}}\left[\frac{k^{2} \sigma_{G}^{4}}{r^{2}(t-1)^{2}}\left[\frac{\left(\sigma^{2}+r \sigma_{h}^{2}+\frac{r(t-1)}{k} \sigma_{M}^{2}\right)^{2}}{k}+\frac{\left(\sigma^{2}+r \sigma_{h}^{2}\right)^{2}}{t-k-1}\right]+\right.
$$$$
\left.+\frac{\sigma_{M}^{4}}{r^{2}}\left[\frac{\left[\sigma^{2}+r \sigma_{G}^{2}\right]^{2}}{t-1}+\frac{\sigma^{4}}{t(r-1)}\right]-\frac{2 \sigma_{M}^{4}}{k r(t-1)} \sigma_{G}^{2}\left[2 k \sigma^{2}+2 k r \sigma_{h}^{2}+r(t-1) \sigma_{M}^{2}\right]\right]
$$$$
f_{R^{2}}(z)=\frac{\left(\sigma^{2}+r \sigma_{h}^{2}+\frac{r(t-1)}{k} \sigma_{M}^{2}\right)^{\frac{t-k-1}{2}}\left(\sigma^{2}+r \sigma_{h}^{2}\right)^{\frac{k}{2}}}{B\left[\frac{k}{2}, \frac{t-k-1}{2}\right]\left[\sigma^{2}+r \sigma_{b}^{2}+\frac{r(t-1)(1-z)}{k} \sigma_{M}^{2}\right]^{\frac{t-1}{2}} z^{\frac{k}{2}-1}(1-z)^{\frac{t-k-1}{2}-1}}
$$

87

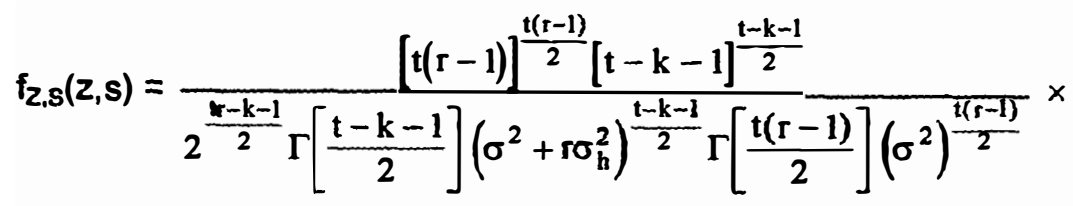

$\times \frac{(1+z)^{\frac{t-k-1}{2}-1} s^{\frac{t r-k-1}{2}-1}}{z^{\frac{t-k-1}{2}+1}} \exp \left\{-s \frac{(t-k-1)(1+z)}{2 z\left(\sigma^{2}+r \sigma_{h}^{2}\right)}\right\} \exp \left\{-\frac{t(r-1)}{2 \sigma^{2}} s\right\}$

(4.47)

$f_{\hat{b}_{M}}(z)=\frac{[t-k-1]^{\frac{t-k-1}{2}}[t(r-1)]^{\frac{t(r-1)}{2}}\left[\sigma^{2}+r \sigma_{h}^{2}\right]^{\frac{t(t-1)}{2}} \sigma^{t-k-1}}{B\left[\frac{t-k-1, t(r-1)}{2,} 2\right]} \times$

$\times \frac{(1+z)^{\frac{t-k-1}{2}-1} z^{\frac{t(r-1)}{2}-1}}{\left[t(r-1) z\left(\sigma^{2}+r \sigma_{h}^{2}\right)+(t-k-1)(1+z) \sigma^{2}\right]^{\frac{t-k-1 /(r-1)}{2}}}$

Tabela 6 Onde se lê, na quarta coluna, $0,0260,0,0580,0,1020,0,1640$ e 0,2036, leia-se, respectivamente: 0,0280, 0,064, 0,111, 0,172 e 0,2087. 


\section{SIMULAÇÃO DE SELEÇÃO RECORRENTE ASSISTIDA POR MARCADORES MOLECULARES EM ESPÉCIES AUTÓGAMAS}

EDUARDO BEARZOTI

Aprovada em : 02.12.1997

Comissão julgadora:

Prof. Dr. Roland Vencovsky

ESALQ/USP

Prof. Dr. Natal Antonio Vello

ESALQ/USP

Prof. Dr. Claudio Lopes de Souza Júnior ESALQ/USP

Prof. Dr. Daniel Furtado Ferreira

UFLA

Prof. Dr. João Bosco dos Santos

UFLA

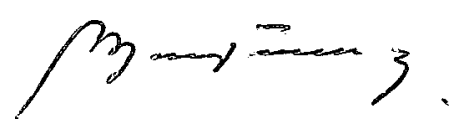

Prof. Dr. ROLAND VENCOVSKY

Orientador 
Dedico este trabalho à memória do

Prof. Paulo Sodero Martins, de quem tive o privilégio de ter sido aluno. 


\section{AGRADECIMENTOS}

Seria impossivel mencionar todos aqueles que contribuíram para que eu tivesse êxito na condução deste trabalho. No entanto, gostaria de expressar meus sinceros agradecimentos à pessoa do Prof. Roland Vencovsky, pelo privilégio de sua orientação competente e amizade, e sua valiosa contribuição em meu amadurecimento científico. Também sou grato à Escola Superior de Agricultura "Luiz de Queiroz" pela oportunidade de treinamento, em especial aos professores e funcionários do Departamento de Genética e de Matemática, bem como aos colegas de curso. Agradeço ainda ao CNPq pelo apoio financeiro.

Devo ressaltar ainda o apoio que recebi de meus colegas de trabalho da Universidade Federal de Lavras, e agradecer a minha esposa Giovana, pelo seu companheirismo e paciência em todo esse período árduo que caracteriza um curso de Doutorado. 


\section{SUMÁRIO}

Página

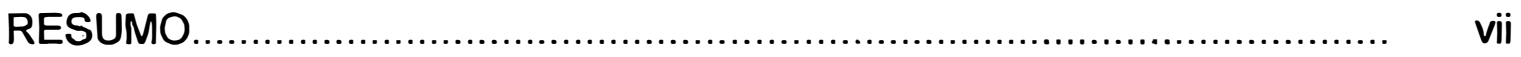

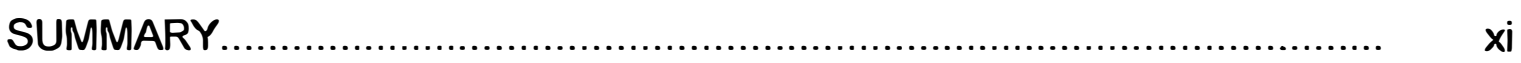

1 INTRODUÇÃO

2 REVISÃO DE LITERATURA .............................................................

2.1 Seleção recorrente em plantas autógamas........................................... 4

2.2 Detecção de poligenes através de marcadores moleculares................ 16

2.3 Desequilíbrio de ligação em plantas autógamas................................ 28

2.4 Seleção assistida por marcadores.................................................... 30

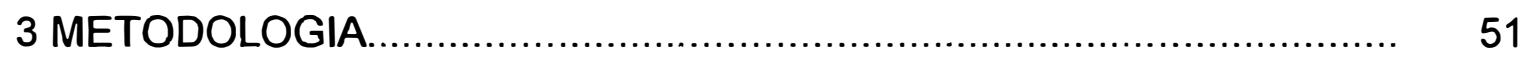

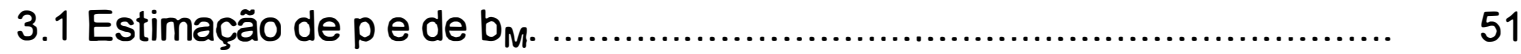

3.2 Avaliação da SAM em espécies autógamas...................................... 53

3.2.1 Simulação do genoma e da gametogênese..................................... 53

3.2.2 Esquema de seleção recorrente utilizado........................................ 56

3.2.3 Simulação da variância ambiental entre e dentro de parcelas.......... 62

3.2.4 Utilização de marcadores na simulação........................................... 65

3.2.5 Avaliação da eficiência da SAM..................................................... 67

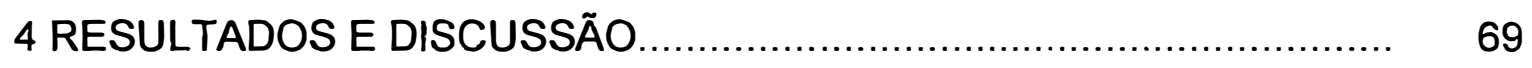

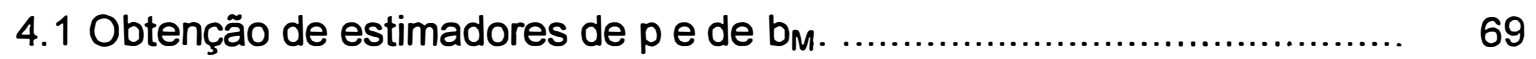




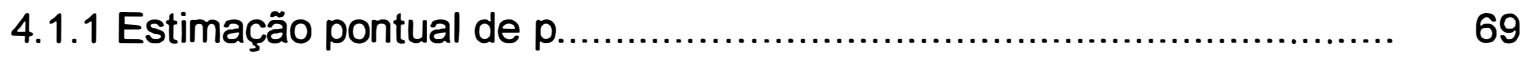

4.1.2 Distribuição de amostragem de $\hat{\mathrm{p}}$................................................... 75

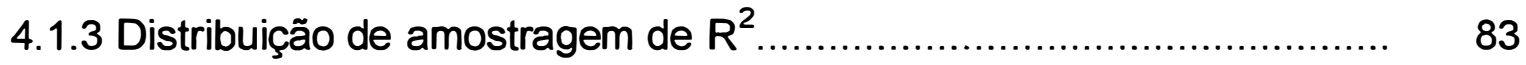

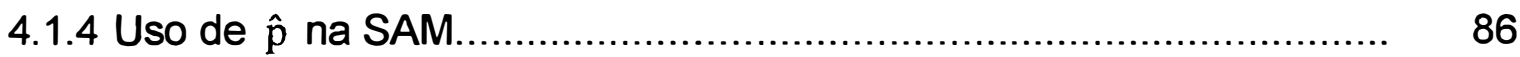

4.2 Avaliação da SAM em espécies autógamas....................................... 88

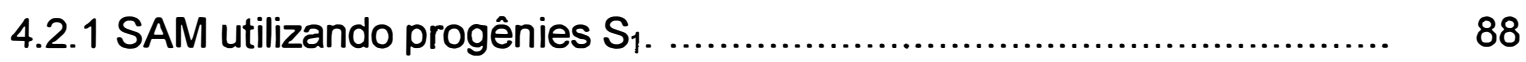

4.2.2 Efeito de $h^{2}$ na eficiência da SAM.............................................. 94

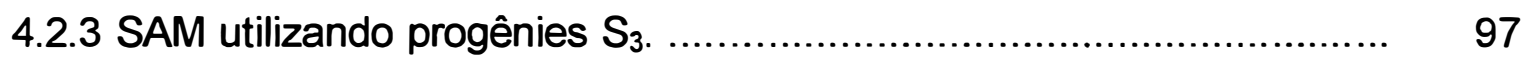

4.2.4 Efeito do tamanho da população na eficiência da SAM.................... 99

4.2.5 SAM em presença de dominância completa.................................. 102

4.2.6 Efeito da proporção de progênies selecionadas na SAM.................. 104

4.2.7 Efeito da heterogeneidade do solo na SAM................................. 110

4.2.8 Efeito do número de marcadores na SAM.................................... 113

4.2.9 Efeito do tamanho efetivo na SAM................................................ 116

4.2.10 Considerações finais.......................................................... 118

5 CONCLUSÕES................................................................. 121

REFERÊNCIAS BIBLIOGRÁFICAS.................................................. 124

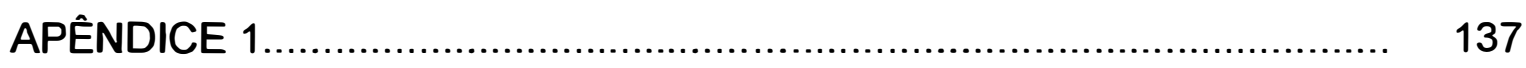

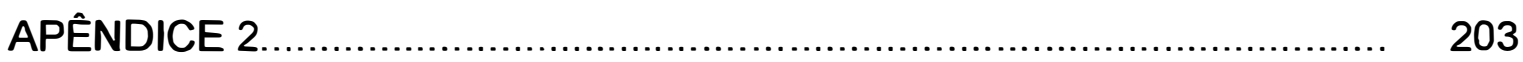




\section{SIMULAÇÃO DE SELEÇÃO RECORRENTE ASSISTIDA POR \\ MARCADORES MOLECULARES EM ESPÉCIES AUTÓGAMAS}

Autor: EDUARDO BEARZOTI

Orientador: PROF. DR. ROLAND VENCOVSKY

\section{RESUMO}

A seleção recorrente em espécies autógamas consiste em um procedimento que pode aumentar a probabilidade de combinações genotípicas superiores, em virtude do aumento da frequência de alelos favoráveis. Entretanto, trata-se de uma prática de difícil execução, principalmente devido ao fato de a etapa de recombinação quase sempre ter de ser manual. Suas dificuldades inerentes demandam a busca por metodologias que aumentem sua eficiência. A seleção assistida por marcadores moleculares pode contribuir nesse sentido, uma vez que quase sempre algum desequilíbrio de ligação é restabelecido em cada ciclo seletivo, em decorrência do uso frequente de unidades de seleção com algum grau de endogamia.

Para tanto, é fundamental a estimação da proporção da variância genética explicada por marcadores moleculares $(p)$, se um índice de seleção for utilizado, combinando as informações fenotípica e molecular. Embora o coeficiente de determinação $\left(R^{2}\right)$ seja por vezes empregado para esse fim, não é claro sob quais circunstâncias esta estatística é adequada, e se não haveria outros estimadores mais apropriados.

Face aos aspectos levantados, este trabalho teve por objetivos: a) a obtenção de um estimador da proporção da variância genética explicada por marcadores moleculares, e a avaliação de algumas de suas 
propriedades e de sua utilização na seleção assistida por marcadores; e b) a avaliação da seleção assistida por marcadores moleculares em espécies autógamas, mediante simulação em computador, sob diferentes valores de parâmetros genéticos e de outros fatores.

Um estimador da proporção $p$ da variância genética explicada por marcadores moleculares foi obtido considerando situações em que modelos de regressão múltipla são utilizados, tendo o número de cópias de um dos alelos de vários locos marcadores como variáveis regressoras. Também considerou-se como variável dependente a média fenotípica de progênies avaliadas em experimentos com repetições.

Para a avaliação da seleção assistida por marcadores em plantas autógamas, linhagens endogâmicas foram simuladas, em número de 5 (na maioria das situações), cada qual participando de dois cruzamentos mediante um esquema de dialelo circulante, formando assim uma populaçãobase composta por 5 subpopulações. Em cada uma destas, 400 plantas $S_{0}$ ou $\mathrm{S}_{2}$ eram classificadas quanto ao genótipo de 130 locos marcadores codominantes, ao longo de um genoma fictício de 10 Morgans. Neste genoma, 50 QTL's foram dispostos aleatoriamente, apresentando efeito diferenciado. As progênies obtidas daquelas plantas $S_{0}$ ou $S_{2}$ eram dispostas em 2 repetições. Os descendentes obtidos por autofecundação das progênies selecionadas formavam novas 5 subpopulações em um ciclo seletivo seguinte. Ao todo, 6 ciclos de seleção foram simulados em 10 repetições, para cada conjunto de valores para parâmetros possivelmente influentes. A seleção assistida por marcadores foi praticada mediante o índice de seleção de Lande \& Thompson (1990), e avaliada comparando-a com a seleção baseada apenas nas médias fenotípicas das progênies. Para quantificar o nivel de desequilíbrio de ligação em um dado ciclo seletivo, foram considerados todos os pares de locos marcadores distanciados de 16,67 cM apresentando polimorfismo, tomando-se o valor médio do desequilíbrio. 
Quando o número de progênies é pequeno (da ordem de 10), tanto o estimador proposto da proporção da variância genética explicada por marcadores moleculares, como o coeficiente de determinação, mostraramse insatisfatórios, devido à sua tendenciosidade ou baixa precisão. Por outro lado, se a herdabilidade da característica for alta, ou tanto este parâmetro como $p$ forem altos, o coeficiente de determinação $R^{2}$ mostrou-se mais apropriado. Se o número de progênies avaliadas for alto (algumas centenas), o estimador proposto tem um vício consideravelmente menor que o de $\mathrm{R}^{2}$, e com um nível de precisão tolerável. Nesses casos, intervalos de confiança para $p$ podem ser construídos utilizando a aproximação normal.

Os resultados de uma forma geral não atestaram a seleção assistida por marcadores como eficiente, por mais de um único ciclo seletivo, em todas as situações consideradas. A razão principal dessa falta de eficiência foi tida principalmente pelo fato de que, ao contrário de estudos anteriores, nos quais foram consideradas populações-base formadas a partir do cruzamento de duas linhagens endogâmicas apenas, nesse estudo optou-se pela simulação de uma população-base formada a partir de várias linhagens. Isto fez com que ocorressem misturas de diferentes fases de ligação entre locos marcadores e aqueles controladores da característica em questão, diminuindo o nível de desequilíbrio de ligação ao longo dos ciclos seletivos, apesar do uso de unidades de recombinação endogâmicas.

Quando considerada por apenas um ciclo seletivo, a seleção assistida por marcadores mostrou-se eficiente, especialmente se praticada em gerações precoces de autofecundação, e quando a característica apresentou baixa herdabilidade. O tamanho das subpopulações nas quais a metodologia foi aplicada afetou sobremaneira sua eficiência, demandando a avaliação de algumas centenas de progênies por cruzamento. A técnica mostrou-se promissora no primeiro ciclo seletivo, mesmo em presença de dominância positiva completa. O uso de 200 locos marcadores, ao invés de 130, 
propiciou melhorias apenas modestas de eficiência. Baixos valores do coeficiente de heterogeneidade de solo de Smith (1938), com consequentes reduções na herdabilidade, também não aumentaram sobremaneira a eficiência do uso de marcadores moleculares.

Para que a seleção assistida por marcadores se mantivesse eficiente por mais de um ciclo seletivo, testou-se o uso de seleção de apenas uma progênie por cruzamento ( $e$, consequentemente, apenas duas progênies para compor subpopulações, em ciclos seguintes). Este procedimento de fato aumentou o desequilíbrio de ligação gerado na etapa de recombinação, mas mostrou-se inadequado a longo prazo, devido à ocorrência de alta deriva genética, tanto em QTL's como em locos marcadores, reduzindo o nível de polimorfismo. $\mathrm{O}$ uso de um alto tamanho efetivo populacional, pelo uso de $\mathbf{2 0}$ linhagens para compor a população-base, não foi suficiente para contornar o problema da deriva genética, evidenciando a dificuldade de se estabelecer um programa de melhoramento em espécies autógamas com características tais que a seleção assistida por marcadores se justifique. 


\title{
SIMULATION OF MARKER-ASSISTED RECURRENT SELECTION \\ IN AUTOGAMOUS SPECIES
}

\author{
Author: EDUARDO BEARZOTI \\ Adviser: PROF. DR. ROLAND VENCOVSKY
}

\section{SUMMARY}

Recurrent selection in cultivated autogamous species is a procedure that can enlarge the probability of obtaining superior genotypes, by increasing the frequencies of favorable genes. However, the practice is difficult to be carried out mainly because recombination generally needs to be made manually. These inherent difficulties require the search for methodologies to enhance its efficiency. This can be partly achieved through marker-assisted selection, since almost certainly some level of linkage disequilibrium will be restored, at every cycle of selection, when inbred lines are used as selection units.

In marker-assisted selection, the estimation of the proportion of the genetic variance explained by molecular markers $(p)$ is imperative, when a selection index, combining both phenotypic and molecular information, is used. The coefficient of determination $\left(R^{2}\right)$ is sometimes taken for this purpose, but it is not clear under which circumstances this statistic is suitable, and whether there are better estimators.

Considering these points, the main objectives of this work were: a) to obtain an estimator of the proportion of the genetic variance explained by molecular markers, and to evaluate its properties and its use in marker-assisted selection; b) to evaluate marker-assisted selection in 
autogamous species through computer simulation, assuming different genetic and non-genetic parameters conditions.

An estimator of the proportion of genetic variance explained by molecular markers was obtained considering a multiple regression model, in which the numbers of one of the alleles, at several marker loci, are the regressor variables. The dependent variable was the phenotypic mean of progenies evaluated in replicated trials.

The evaluation of marker-assisted selection in autogamous species was performed by simulating 5 inbred lines (in most of the situations considered), each crossed with two others, in a circulant diallel scheme, such that a base population of 5 crosses was formed. Within each cross, $400 \mathrm{~S}_{0}$ or $\mathrm{S}_{2}$ plants were genotyped in relation to 130 marker loci, spread over a genome of 10 Morgans. In this genome, 50 QTL of different effects were located randomly. Progenies derived from those $S_{0}$ or $S_{2}$ plants were replicated twice, and evaluated with respect to the simulated trait. The descendants of the selected progenies formed 5 new subpopulations in a next selective cycle. For each situation, 6 cycles were simulated in 10 replications. The index proposed by Lande \& Thompson (1990) was applied for marker-assisted selection and its efficiency measured by comparing the average progress attained with that found assuming selection based solely on phenotypic progeny means, for the simulated trait. The level of linkage disequilibrium in a given cycle was quantified by the average value observed in all pairs of polimorfic marker loci, $16.67 \mathrm{~cm}$ distant of one another.

The proposed estimator of the proportion of genetic variance explained by molecular markers, and the coefficient of determination, were both unsatisfactory with small numbers of progenies (about 10), due to strong bias and/or low precision. However, if heritability of the trait is high, or both heritability and $p$ are high, then the coefficient of determination $R^{2}$ showed to be more suitable. If the number of evaluated progenies is large (as a few hundreds), the 
proposed estimator was less biased than $\mathrm{R}^{2}$, and had an acceptable precision. Under these circumstances, confidence intervals for $p$ can be constructed based on approximations to the normal distribution.

Results in general showed that marker-assisted selection is not efficient, after the first cycle of selection, for all situations considered. These results are not in agreement with previous reports on computer simulation of marker assisted selection. The reason for this contrast must have been that, while in most of other works the base population was constructed by crossing only two inbred lines, in this study the base population was formed by intercrossing several inbred lines. This caused a mixture of different gametic phases between marker loci and quantitative trait loci, thus reducing the amount of linkage disequilibrium, in advanced cycles, despite the use of inbred selection units.

When considering a single cycle of selection, markerassisted selection showed to be efficient, specially if practiced in early generations of inbreeding, and under low heritability. The size of the population strongly affects its efficiency, requiring the evaluation of some hundreds of progenies. The technique was promising in a single cycle of selection even in the presence of complete positive dominance. The use of 200 marker loci yielded only slight improvement in efficiency, in relation to 130 marker loci. Low values of the coefficient of soil heterogeneity of Smith (1938), which lowered heritability, did not markedly increase the efficiency of marker-assisted selection, either.

In order to search for situations in which marker-assisted selection could be effective in subsequent cycles, the selection of a single progeny per cross was also simulated. This led to the formation of subpopulations consisting of only two inbred lines, in all cycles, and a consequent increase of linkage disequilibrium in the recombination process. In spite of this, the effectiveness of marker-assisted selection was not improved in a long term basis, mainly due to genetic drift that was detected not only for 
QTL's but for marker loci as well, thus reducing the degree of polymorphism. Increasing effective population size through a large number $(20)$ of inbred lines to form the base population was not sufficient for reducing the effect of drift. These results clearly showed that finding the ideal situations for marker-assisted selection to be effective in autogamous species is a difficult task. 


\section{INTRODUÇÃO}

O melhoramento de plantas autógamas relativo a características de natureza quantitativa tem sido tradicionalmente praticado pelo uso de populações obtidas a partir do cruzamento de dois genitores, seguido do avanço de gerações de autofecundação, mediante diferentes métodos. Dentre estes, destacam-se o massal e o genealógico, embora diversas variações sejam usadas, como o de descendentes de uma única semente e o massal dentro de famílias.

Embora este sistema básico tenha sido responsável por grande parte dos resultados obtidos no melhoramento de diversas culturas, ele apresenta algumas características que podem limitar o ganho com a seleção. A utilização, em geral, de apenas dois genitores para compor a população-base a ser melhorada, bem como o sistema reprodutivo de autofecundação, limitam o tamanho efetivo da população, e consequentemente a probabilidade de fixação de alelos favoráveis. Em vista disso, a seleção recorrente foi proposta como uma alternativa para o melhoramento de plantas autógamas (Khadr \& Frey, 1965). Este sistema permite a condução de populações de maior tamanho efetivo, em vários ciclos seletivos, pela utilização de mais de duas linhagens para iniciar o programa de melhoramento e pelo uso de gerações de recombinação. Dessa maneira, a probabilidade de obtenção de combinações genotípicas favoráveis seria aumentada, em relação ao sistema tradicional. 
Apesar das vantagens previstas em teoria, a seleção recorrente em plantas autógamas, em relação àquela em alógamas, tem sido relativamente pouco utilizada, basicamente em virtude da dificuldade de promover a recombinação, pois os cruzamentos em geral têm de ser feitos manualmente. Nesse sentido, sempre que possivel, devem ser buscadas metodologias que facilitem a prática da seleção recorrente em tais culturas, bem como aumentar o ganho esperado com a seleção, em virtude do tempo e recursos demandados, e das dificuldades apontadas.

O uso da seleção assistida por marcadores (por exemplo, Lande \& Thompson, 1990) poderia aumentar a eficiência do processo seletivo em plantas autógamas, pela deteç̧ão de locos controladores da característica quantitativa em questão (QTL's), e utilização dessa informação na identificação dos melhores indivíduos ou progênies. Especialmente nos últimos anos, técnicas de marcação molecular altamente eficientes têm sido desenvolvidas, como a do polimorfismo de comprimento de fragmentos amplificados (AFLP) e a da amplificação de segmentos de DNA de sequência repetida (SSR).

No contexto específico da seleção recorrente de plantas autógamas, o uso de marcadores é potencialmente vantajoso, pois autofecundações são comumente realizadas ao longo dos ciclos seletivos, e assim a geração de desequilíbrio de ligação é facilitado pelo cruzamento de materiais endogâmicos. No entanto, para a utilização efetiva da técnica, é necessária uma avaliação de sua eficiência potencial sob diferentes condições. Para tanto, o uso de simulaçảo em computador corresponde a uma ferramenta poderosa, pois permite avaliar seu desempenho ao longo de vários ciclos seletivos (o que em uma situação real demandaria muitos anos), variando parâmetros importantes, como a herdabilidade da característica, o grau de dominância, a intensidade de seleção, dentre outros.

$\mathrm{Na}$ prática da seleção assistida por marcadores moleculares, é de fundamental importância a estimação da proporção da 
variância genética explicada pelos marcadores, pois ela permite a utilização de índices de seleção, além da previsão do ganho esperado çom a técnica. Embora o coeficiente de determinação $\left(R^{2}\right)$ seja por vezes empregado para esse fim, fazem-se necessários estudos para verificar sob quais circunstâncias esta estatística é adequada, e se não haveria outros estimadores mais apropriados.

Face às considerações levantadas, este estudo teve por objetivos:

a) A obtenção de um estimador da proporção da variância genética explicada por marcadores moleculares, e a avaliação de algumas de suas propriedades e de sua utilização na seleção assistida por marcadores;

b) A avaliação do uso de marcadores moleculares na seleção recorrente em espécies autógamas, mediante a simulação de programas de melhoramento em computador, sob diferentes valores de parâmetros genéticos e de outros fatores. 


\section{REVISÃO DE LITERATURA}

\subsection{Seleção Recorrente em Plantas Autógamas}

A seleção recorrente consiste em um método de melhoramento originalmente proposto para plantas alógamas (Jenkins, 1940; Hull, 1945), com o objetivo de aumentar a frequência de alelos favoráveis na população em questão, com relação à característica de interesse. Com o desenvolvimento da genética quantitativa, ao longo da segunda metade desse século, tornou-se possível quantificar o ganho esperado com a seleção recorrente. Isso contribuiu para que a técnica fosse popularizada e otimizada, pela escolha de unidades de seleção e de recombinação de maneira a maximizar sua eficiência. A utilização da seleção recorrente em plantas alógamas, notadamente na cultura do milho, tem sido de importância notória para a obtenção de populações melhoradas, tanto para uso "per se", como para a extração de linhagens superiores, visando a produção de híbridos (Schnicker \& Lamkey, 1993).

Sua utilização em plantas autógamas, embora sugerida há algumas décadas (Khadr \& Frey, 1965; Matzinger \& Wernsman, 1968; Compton, 1969), teve uma aceitação mais tardia e em menor grau, em relação àquela em plantas alógamas, tendo ganhado impulso relevante somente a partir do final da década de 1970 (Fehr \& Ortiz, 1975; McNeal et al., 1978; Miller \& Fehr, 1979; Brim \& Burton, 1979; Kenworthy \& Brim, 1979). 
McFerson \& Frey (1991) apontam as seguintes razões para essa menor utilização: dificuldade de intercruzamento dos genótipos superiores, limitação na disponibilidade de sementes para a instalação de ensaios com repetições, em mais de um local, e o tempo necessário para completar um ciclo seletivo. $O$ fato de a recombinação ter de ser (em geral) manual é uma limitação enfatizada por diferentes autores (Compton, 1969; Khadr \& Frey, 1965; Pomeranke \& Stuthman, 1992), embora a duração do ciclo seletivo seja um aspecto que também contrasta significativamente com a seleção recorrente praticada em plantas alógamas. Isso se deve à necessidade frequente de condução de gerações adicionais de autofecundação.

Basicamente, a seleção recorrente é um processo cíclico de melhoramento populacional, que envolve as seguintes etapas, que se sucedem continuamente: amostragem de indivíduos ou progênies da população em questão, avaliação destes com relação à característica de interesse, seleção dos superiores, e cruzamento destes entre si. Este último processo é denominado de recombinação, e origina a população que passará por estas mesmas etapas em um novo ciclo seletivo. Geraldi (1995) resume as principais vantagens da seleção recorrente em plantas nas seguintes:

a) obtenção de maior variabilidade genética pelo intercruzamento de múltiplos genitores;

b) maior oportunidade de recombinação genética, devido aos cruzamentos ao longo dos ciclos;

c) aumento cumulativo da frequência de alelos favoráveis;

d) maior facilidade de incorporação de germoplasma exótico naquele adaptado.

A vantagem (c) apontada acima é particularmente importante para as espécies autógamas, uma vez que a maior parte dos programas de melhoramento objetiva a obtenção de linhagens endogâmicas 
superiores. A probabilidade de reunir em uma única linhagem alelos favoráveis relativos a diversos locos corresponde ao produtório das frequências, alélicas na população. Se estas são iguais a $\mathrm{p}_{\mathrm{f}}$ para todos os locos, então o número de locos com alelos favoráveis fixados tem distribuição binomiail com probabilidade de sucesso $p_{f}$. A Tabela 1 apresenta a frequência esperada de linhagens endogâmicas contendo pelo menos a metade dos locos com alelos favoráveis, para alguns números de genes e de $p_{f}$. Observa-se, por exemplo, que, independentemente do número de locos, a frequência dessas linhagens aumenta consideravelmente se $p_{f}$ aumentar de 0,3 para 0,5 .

No planejamento de um programa de melhoramento envolvendo seleção recorrente, deve-se levar em conta que se trata de um processo dinâmico, no sentido de que, em cada ciclo, os genótipos superiores podem ser liberados (obtenção de cultivares), bem como utilizados para dar início a um novo ciclo seletivo (Geraldi, 1995). Assim, o processo de seleção recorrente em uma população pode ser comparado a um tronco principal, dotado de ramificações secundárias, correspondentes a programas paralelos de obtenção de cultivares. Ainda segundo Geraldi (1995), um programa de melhoramento de plantas autógamas completo poderia compreender as seguintes etapas:

a) cruzamento entre múltiplos genitores, incluindo materiais exóticos;

b) prática da seleção recorrente;

c) obtenção de linhagens da população melhorada;

d) seleção das linhagens superiores.

A obtenção e seleção de linhagens em uma população melhorada envolve a condução de gerações de autofecundação, a qual pode ser feita pelos métodos clássicos utilizados posteriormente a cruzamentos biparentais. Dentre estes métodos, destacam-se o massal e o genealógico, e 
suas variações: descendentes de uma única semente e massal dentro de familias (Ramalho et al., 1993). Fouilloux \& Bannerot (1988) apresentaram uma ampla discussão sobre a comparação entre esses diferentes métodos. Segundo estes autores, o método genealógico é o mais frequentemente empregado. Apesar de mais laborioso, ele permite a utilização da informação da genealogia para melhor estimar o valor genético de linhagens, além de permitir inferir sobre o controle genético da característica. Em relação a este método, contudo, Fouilloux \& Bannerot (1988) salientaram uma série de vantagens do método de descendentes de uma única semente, tais como a obtenção de uma população de linhagens que de fato representam a variabilidade do cruzamento, uma vez que não há seleção em gerações anteriores; o fato de a perda de variabilidade só ser função do tamanho da população; e, finalmente, a rapidez no avanço das gerações de autofecundação, em condições de clima temperado. Quanto ao método massal, os autores apontaram que, embora uma perda substancial no número de linhagens possíveis possa ocorrer, em relação ao método anterior, a perda de variabilidade é muito pequena. Assim, em virtude de sua maior facilidade de condução, o método é tido por eles como o mais eficiente.

Estes autores também demonstraram que pouca vantagem existe na avaliação de um número excessivo de linhagens para a seleção da superior, independente do método de condução das gerações de autofecundação. Este aspecto foi ilustrado para o caso de se utilizar descendentes de uma única semente. Seja $\mathrm{N}$ o número de linhagens obtidas por esse método, a partir de uma geração $F_{2}$, na qual $n$ locos apresentavam segregação para um alelo favorável e outro desfavorável. Baseado na distribuição binomial, o número médio de locos com alelos favoráveis nessas linhagens é $n / 2$, com variância $n / 4$. Considerando a aproximação normal como satisfatória, então o valor esperado da melhor linhagem é:

$$
L_{1}=\frac{n}{2}+i_{N} \sqrt{\frac{n}{4}}
$$


em que în é o desvio esperado do melhor indivíduo, em relação à média, em uma amostra de tamanho $\mathbf{N}$ de uma população normal padronizada.

A Tabela 2 mostra o cálculo dessa expressão para diferentes números de locos polimórficos e de tamanhos de população. Conforme se observa, se $\mathrm{n}$ for, diga-se, igual a 40, então o fato de se dobrar o número de linhagens (ou seja, dobrar o custo de sua avaliação) acarreta o aumento de apenas um loco com o alelo favorável fixado, em média.

Utilizando um enfoque semelhante ao utilizado no estudo do tamanho da população, Fouilloux \& Bannerot (1988) mostraram que, na prática da seleção recorrente em plantas autógamas, também não se justifica a avaliação de um número elevado de progênies. Paralelamente, apresentaram uma argumentação bastante convincente dos benefícios da seleção recorrente. Foram consideradas as duas melhores linhagens $L_{11}$ e $L_{21}$, em um primeiro ciclo seletivo, com $r_{1}$ e $r_{2}$ locos com alelos favoráveis, respectivamente, do total de $n$ genes. Com o cruzamento dessas linhagens, considerou-se a formação de uma nova população, da qual a melhor linhagem $\left(L_{12}\right)$ seria por sua vez selecionada, perfazendo assim um segundo ciclo seletivo. A Tabela 3 mostra o número médio de locos com alelos favoráveis fixados em $L_{11}, L_{21}$, e em $L_{12}$, com diferentes tamanhos de população, em ambos os ciclos, para $n=40$ locos. Novamente nota-se que, sendo dobrado o número de linhagens avaliadas, ocorre o ganho médio aproximado de apenas um loco com o alelo favorável fixado.

A Tabela 4 apresenta os tamanhos de população $N_{1}$ que seriam necessários para se obter, em um único ciclo seletivo, o mesmo número médio de locos com o alelo favorável fixado em 2 ciclos de seleção recorrente, bem como a razão entre os custos envolvidos em ambos os sistemas. Nota-se que os números de linhagens avaliadas, para se obter os mesmos resultados com a seleção recorrente, são surpreendentemente maiores, com um custo total de dezenas a centenas de vezes maior. Estas considerações ilustram claramente os benefícios da seleção recorrente em plantas autógamas. 
Conforme se observou anteriormente, uma das dificuldades da seleção recorrente em plantas autógamas é a recombinação, que em geral tem de ser manual. Contudo, em certas espécies, a existência de mecanismos relativamente estáveis de machoesterilidade permite contornar esse problema, ao menos em parte, pela utilização de esquemas de seleção apropriados. Tal é o caso da cultura do arroz. No Brasil, tem-se utilizado como fonte de machoesterilidade um mutante da cultivar IR 36 , através do alelo ms. Quando as plantas se encontram em homozigose, seus grãos de pólen são inviáveis. Rangel \& Neves (1995a) propuseram um esquema para utilização em arroz irrigado, denominado Método de Seleção Recorrente em Famílias $S_{0: 2}$. $O$ primeiro passo consiste na obtenção da população base, através de retrocruzamentos com a fonte de machoesterilidade. As etapas posteriores podem ser resumidas da seguinte forma:

1) no ano 1 (safra) é plantada a população $S_{0}$ do ciclo 0 , contendo $50 \%$ de plantas machoférteis (Msms) e $50 \%$ de machoestéreis (msms). São colhidas sementes nas primeiras, sendo que uma parte é armazenada;

2) plantio de progênies $S_{0: 1}$ na entressafra, colhendo-se as machoférteis;

3) avaliação de progênies $S_{0: 2}$ na safra do ano 2 , em diversos locais;

4) recombinação utilizando as sementes remanescentes $S_{0: 1}$ (entressafra). São colhidas sementes nas plantas machoestéreis;

5) na safra do ano 3, a população do ciclo 1 é plantada. Ao todo, são dispendidos dois anos para completar um ciclo seletivo.

Este é o sistema básico do programa de seleção recorrente de arroz irrigado, coordenado pelo Centro Nacional de Pesquisa de Arroz e Feijão (CNPAF-EMBRAPA), conforme Rangel \& Neves (1995b). O programa é 
talvez o de maior monta praticado em uma espécie autógama no país, contando com 0 apoio de outros centros de pesquisa da EMBRAPA e outros órgãos (EPAGRI, EPAMIG), permitindo a avaliação das linhagens $S_{0: 2}$ em diversos estados do país. Uma das desvantagens do sistema acima é a da ocorrência de plantas machoestéreis nas progênies avaliadas $S_{0: 2}$ (etapa 3 ), as quais sabidamente dificultam a estimação do valor genotípico das progênies.

Outros autores têm sugerido e feito uso do fenômeno da machoesterilidade, notadamente na cultura da soja (Brim \& Stuber, 1973; Burton et al., 1990). Werner \& Wilcox (1990) construíram uma população-base misturando sementes de uma linhagem comercial com as de duas populações $F_{2}$, segregantes para um gene que confere machoesterilidade no genótipo homozigoto recessivo. Colhendo sementes apenas nas plantas machoestéreis, obtiveram plantas $S_{0}$, as quais foram avaliadas com relação à produtividade de grãos. Dentre as selecionadas, foram tomadas 15 sementes. Na geração seguinte, novamente foram colhidas apenas as plantas machoestéreis, e assim sucessivamente por 3 ciclos seletivos.

Além do uso de machoesterilidade, McFerson \& Frey (1991) apontaram como principais estratégias utilizadas para aumentar a eficiência da seleção recorrente em espécies autógamas: uso de técnicas de cruzamento mais eficientes, avaliação precoce, uso de microparcelas e utilização de casas de vegetação no inverno.

Desde os resultados obtidos por Frey (1965), o uso de microparcelas, ou parcelas em cova, tem sido extensivo no melhoramento de soja. Este autor encontrou uma alta correlação genética entre valores observados em unidades experimentais maiores e os de parcelas em cova, para caracteristicas de importância econômica.

Pomeranke \& Stuthman (1992) avaliaram materiais selecionados em cada um de 5 ciclos de um programa de seleção recorrente 
para produção de grãos em aveia, totalizando 126 genótipos. A avaliação foi feita tanto em parcelas em covas de 30 sementes, como em linhas de 3 metros, sendo que para cada caso uma análise de regressão foi feita, da média dos genótipos em função do ciclo seletivo. Os coeficientes de regressão foram estatisticamente diferentes de 0 , e iguais entre si, evidenciando a eficiência do uso de parcelas menores.

Ao longo dos anos, tem-se observado resultados experimentais evidenciando resposta à seleção recorrente em plantas autógamas. Khadr \& Frey (1965), em um dos trabalhos pioneiros que a utilizaram, observaram ganhos estatisticamente significativos no peso de 100 sementes em aveia, nas 4 populações com as quais trabalharam, em um ciclo de seleção. Matzinger \& Wernsman (1968) utilizaram seleção massal em Nicotiana tabacum por 4 ciclos de seleção, tendo obtido um ganho médio em cada ciclo de $44 \mathrm{~g}$ de folhas verdes por planta. Os autores justificaram o sucesso da seleção massal em parte devido a ela poder ter sido praticada antes do florescimento, e assim o controle parental compreendeu ambos os sexos.

McNeal et al. (1978) promoveram seleção recorrente para o aumento no teor de proteína em trigo em 2 ciclos de seleção, tendo obtido um ganho médio final correspondente a $2,5 \%$. Com relação a essa mesma característica, o melhoramento da cultura da soja também tem sido eficaz mediante seleção recorrente (Miller \& Fehr, 1979; Brim \& Burton, 1979).

Kenworthy \& Brim (1979), em 3 ciclos de seleção para a produtividade de grãos em soja, registraram um ganho de $134 \mathrm{~kg} / \mathrm{ha}$ por ciclo. Os autores ressaltaram a necessidade de se buscar procedimentos para diminuir o tempo e os recursos em ciclos de seleção recorrente, tais como o uso da machoesterilidade e de parcelas experimentais pequenas. Garland \& Fehr (1981), utilizando parcelas convencionais e de menor tamanho, obtiveram ganhos, respectivamente, de 5,1 e $7,6 \mathrm{~kg} / \mathrm{ha}$ por ano. A principal vantagem do 
uso de unidades experimentais reduzidas decorreu do menor número de gerações para multiplicação de sementes.

Busch \& Kofoid (1982) promoveram seleção recorrente para o peso de grãos em trigo. A partir da avaliação simultânea de amostras de plantas $S_{1}$ de cada um dos 4 ciclos seletivos praticados, observaram um ganho médio de $7 \%$ em cada um. Sumarno \& Fehr (1982), com 3 ciclos de seleção recorrente em 3 populações de soja diferentes quanto à maturidade, registraram ganhos expressivos na produtividade, especialmente na população precoce (120 kg/ha por ciclo). Payne et al. (1986), trabalhando com aveia, obtiveram um ganho na produtividade de grãos da ordem de $12 \%$ em 3 ciclos de seleção.

O esquema de seleção adotado por Werner \& Wilcox (1990), fazendo uso da machoesterilidade, foi efetivo para a obtenção de ganhos com a seleção, atingindo até $5,4 \mathrm{~g} /$ planta/ciclo. Os autores ressaltaram como vantagens a facilidade de identificação das plantas machoestéreis, e a utilização de seleção precoce.

Outras características de interesse agronômico têm sido submetidas à seleção recorrente em plantas autógamas. Prohasca \& Fehr (1981) promoveram seleção em progênies de soja para tolerância à deficiência de ferro em solos de horizonte cálcico, tendo obtido um ganho médio de $9 \%$ por ano em 2 ciclos seletivos, com relação ao escore de clorose. Avey et al. (1982) praticaram 3 ciclos de seleção para redução do período de início da formação de grãos em trigo. Observaram um ganho superior no primeiro ciclo, seguido de ganhos menores nos ciclos subseqüentes, sugerindo que a característica seria governada predominantemente por genes de efeito maior.

McFerson \& Frey (1990), bem como McFerson \& Frey (1991) relataram a eficiência da seleção recorrente para aumento do teor de proteína em aveia em 3 ciclos seletivos. A população base foi formada a partir de 27 cruzamentos entre 14 genótipos, sendo que famílias obtidas de plantas $F_{2}$ 
eram utilizadas como unidades de seleção em cada cruzamento. Em cada ciclo, familias $S_{1}$ eram selecionadas e intercruzadas em um dialelo parcial $10 \times 10$. Foram utilizadas microparcelas de 20 sementes. Os autores registraram ganhos variando de 21 a $27 \mathrm{~kg}$ de proteína por hectare.

XU \& Wilcox (1992), objetivando o aumento no teor de proteína e na maturidade em soja, construíram uma população base pela mistura de sementes de uma linhagem de alto desempenho com as de duas populações $F_{2}$ nas quais um gene de machoesterilidade estava segregando, de maneira semelhante à praticada por Werner \& Wilcox (1990). Da mesma forma que estes autores, durante 4 ciclos seletivos plantas $S_{0}$ eram avaliadas e selecionadas, sendo utilizadas plantas $S_{1}$ machoestéreis como unidades de recombinação. Foram obtidos ganhos significativos em ambas as características, de 2,7 dias e de 0,8 ponto porcentual, por ciclo, respectivamente.

Todos os programas de seleção mencionados variaram bastante quanto à maneira de escolha das linhagens para formação da população-base, à unidade de seleção utilizada, e ao processo de recombinação dos materiais superiores. Um resumo dessas informações está apresentado na Tabela 5.

Pode-se observar na Tabela 5 que o número de genitores para a formação do ciclo 0 variou muito, de 2 (Brim \& Burton, 1979) a 40 (Sumarno \& Fehr, 1982), embora em geral o número se concentre em torno de 10 a 20. Matzinger \& Wernsman (1968) valeram-se de uma variedade sintética de Nicotiana tabacum, composta por 8 linhagens vindas de 4 origens diversas. Nota-se em geral uma preocupação na reunião de materiais de diferentes procedências ou países (McNeal et al., 1978; Kenworthy \& Brim, 1979; Brim \& Burton, 1979; Garland \& Fehr, 1981; Prohasca \& Fehr, 1981; Payne et al., 1986). Beaver \& Kelly (1994), em um programa de melhoramento de feijão, 
formaram a população-base através de 18 cruzamentos entre genótipos pertencentes aos diferentes centros de domesticação, 0 andino e 0 mesoamericano.

Em outros casos, a formação da população de ciclo 0 teve por principal critério o uso de cultivares ou linhagens disponiveis de alto desempenho quanto à(s) característica(s) desejada(s) (Miller \& Fehr, 1979; Busch \& Kofoid, 1982; Sumarno \& Fehr, 1982; XU \& Wilcox, 1992). Alguns autores, como Payne et al. (1986), procuraram claramente reunir ambos os critérios.

Também a maneira de intercruzar os materiais para compor a população base tem variado entre autores. Alguns têm feito uso de cruzamentos dialélicos (Khadr \& Frey, 1965; Busch \& Kofoid, 1982; Payne et al., 1986), sendo que a maioria parece ter limitado o número de cruzamentos possíveis entre os genitores, devido à sua dificuldade inerente (Miller \& Fehr, 1979; McNeal et al., 1978; Kenworthy \& Brim, 1979; Brim \& Burton, 1979; Garland \& Fehr, 1981). Tanto Miller \& Fehr (1979) quanto Sumarno \& Fehr (1982) optaram por 3 gerações de intercruzamento, sem seleção, para a formação da população base.

Guimarães \& Fehr (1989) estudaram dois outros fatores de importância no delineamento de programas de seleção recorrente em plantas autógamas, quais sejam, o número de ensaios para avaliação das linhagens antes da seleção, e o grau de recombinação praticado entre os materiais superiores. Através da comparação de diferentes estratégias em experimentos de campo, nos quais foi avaliada a produtividade de grãos em soja, observaram que a avaliação em duas épocas (em relação a uma apenas) propiciou ganhos superiores, por ciclo e por ano. Dentre as causas para tanto, os autores destacaram o fato de que, em uma segunda época, é possivel um número maior de ensaios, com parcelas experimentais maiores, possibilitados pelo aumento na disponibilidade de sementes, com o avanço das gerações. Por outro lado, 
não se justificou o uso de mais de uma geração de recombinação, por não ter aumentado a frequência de linhagens superiores.

A unidade de seleção utilizada variou nos trabalhos citados, mas houve um predomínio quanto ao uso de progênies $S_{1}$ derivadas de plantas So (McNeal et al., 1978; Miller \& Fehr, 1979; Kenworthy \& Brim, 1979; Brim \& Burton, 1979; Prohasca \& Fehr, 1981; McFerson \& Frey, 1991). Sumarno \& Fehr (1982), por sua vez, utilizaram predominantemente progênies derivadas de plantas $\mathrm{F}_{4}$, tendo tomado seus descendentes como unidades de recombinação. Payne et al. (1986) também valeram-se de linhas altamente endogâmicas para avaliação e seleção em cada ciclo seletivo, sendo que as gerações de autofecundação foram conduzidas pelo método de descendente de uma única semente até a geração $F_{4}$ e massal dentro de famílias a partir de então. Pomeranke \& Stuthman (1992) reportaram a utilização de progênies $F_{6}$, sendo sua avaliação feita em parcelas em cova.

Em associação com o uso de machoesterilidade, Werner \& Wilcox (1990) e Xu \& Wilcox (1992) utilizaram plantas $S_{0}$ como unidades de seleção.

Beaver \& Kelly (1994) compararam a eficiência entre diferentes niveis de endogamia em unidades de seleção recorrente, no melhoramento de feijão, para características de produção. Foram utilizadas familias $F_{2}$ ou $F_{5}$, em 3 e 2 ciclos seletivos, respectivamente. Em ambos os casos, microparcelas de 10 sementes foram utilizadas. Embora os dois sistemas tenham propiciado ganhos com a seleção significativos, a utilização de famílias $F_{5}$ gerou um número maior de materiais de desempenho superior às testemunhas, apesar de o número de ciclos seletivos ter sido menor. A correlação de Spearman referente ao ordenamento dos materiais selecionados em ambos os sistemas foi baixa. Os autores concluíram assim que o uso de familias $F_{5}$ foi mais eficiente. 
Um número maior de gerações de autofecundação, se por um lado aumenta a duração do ciclo seletivo, por outro aumenta a variância genética aditiva disponivel, e consequentemente o ganho esperado com a seleção (Ramalho \& Venkovsky, 1978; Souza Junior, 1989). O uso de autofecundações é frequentemente justificado pela necessidade de aumentar a quantidade de sementes, permitindo uma avaliação mais extensiva. Pode-se dizer que o número de gerações de autofecundação depende dos objetivos do programa, da característica envolvida e dos recursos disponiveis.

\subsection{Detecção de Poligenes Através de Marcadores Moleculares}

A utilização de marcadores genéticos no estudo de características de natureza quantitativa remonta ao início do século, com o trabalho de Sax (1923). Este autor detectou a associação entre o tamanho e a coloração (cuja herança é qualitativa) em grãos de feijão. Posteriormente, Thoday (1961) apontou suas potencialidades também para a localização de poligenes no mapa genético. Esse tipo de utilização era, no entanto, limitada pelo restrito número de marcadores genéticos disponiveis (em geral de natureza morfológica), além da dificuldade de manutenção de estoques apropriados de materiais genéticos para esse fim.

Os marcadores de natureza molecular ampliaram as possibilidades de detecção e manuseio de poligenes, devido à facilidade relativa de identificação de um maior grau de polimorfismo. Dentre as técnicas de marcação molecular, a de visualização de padrões de eletroforese de isoenzimas em gel de amido foi a pioneira. As isoenzimas correspondem a formas moleculares diferentes de uma mesma enzima e que, embora desempenhando a mesma função catalítica, podem apresentar propriedades 
cinéticas distintas, podendo ser diferenciadas por métodos bioquímicos (Ferreira \& Grattapaglia, 1996). O princípio básico da marcação genética é a de que diferenças na sequência de aminoácidos resultam de diferenças ao nível do DNA que codifica tais sequências. Dessa forma, genes ligados a esses segmentos de DNA podem ser indiretamente identificados.

Tanksley \& Rick (1980) evidenciaram o grande potencial do uso de mapas de ligação de locos isoenzimáticos no melhoramento do tomateiro e de outras culturas em geral. A técnica de visualização de padrões de eletroforese de isoenzimas, ainda que originada na década de 1950, não havia, até então, sido utilizada para marcação genética em larga escala. Os autores apontaram como principais vantagens da técnica (em relação aos marcadores morfológicos) a herança codominante, a ausência de epistasia e o número muito maior de marcas potencialmente segregando simultaneamente em uma população.

Tanksley et al. (1981) detectaram correlações significativas entre variações em características quantitativas e aquelas em genótipos de locos isoenzimáticos, em tomate. A técnica mostrou potencial maior que o uso de marcadores morfológicos para reduzir 0 número de gerações de retrocruzamento. $O$ uso de isoenzimas permitiu um amplo estudo sobre a natureza de diversas características de natureza contínua em milho (Edwards et al., 1987), em particular aquelas componentes da produtividade de grãos (Stuber et al., 1987). Estes trabalhos possibilitaram a identificação de aspectos detalhados sobre o controle genético dessas características, como diferentes magnitudes quanto ao efeito dos poligenes detectados e ao seu grau de dominância, o que antes era pouco viável pelos métodos clássicos de genética quantitativa.

Weller et al. (1988), trabalhando com uma geração $F_{2}$ de um cruzamento interespecífico em tomate, detectaram ligações entre locos isoenzimáticos e genes controladores de 18 características quantitativas. Em 
média, os efeitos detectados foram da ordem de $6 \%$ da média geral observada de cada característica.

Outro marcador molecular, que veio a se tomar um dos mais largamente empregados no fitomelhoramento, é o que se baseia em fragmentos de DNA polimórficos quanto ao comprimento, obtidos a partir de enzimas de restrição, Esta metodologia, mais conhecida por sua sigla em inglês, RFLP, foi originalmente empregada na espécie humana (Botstein et al., 1980). O princípio envolvido nesta técnica é o de que indivíduos apresentando diferenças quanto à sequência de bases em seu DNA possuem sítios de restrição em pontos distintos do genoma. Dessa forma, a digestão de seu material genético com enzimas de restrição provoca o aparecimento de fragmentos de DNA com diferenças em seu comprimento. Para discriminá-las, é preciso submeter o produto digerido à eletroforese em gel em agarose. Posteriormente, o DNA é transferido para uma membrana de "nylon" ou nitrocelulose, por uma técnica denominada de "Southern Blot", que mantem constante o posicionamento dos fragmentos separados pela eletroforese. Finalmente, estes fragmentos sofrem uma hibridação com sondas, que nada mais são do que pequenas sequências de c-DNA, homólogas àquelas dos fragmentos. As sondas possuem nucleotídeos modificados (com fósforo radioativo, ou com digoxigenina ou biotina), permitindo a visualização do padrão ocorrido na eletroforese. Com a metodologia de RFLP, portanto, a detecção do polimorfismo é resultante da combinação entre diferentes enzimas de restrição com diferentes sondas.

Beckman \& Soller (1986) traçaram considerações acerca das potencialidades dessa técnica para a manipulação de características quantitativas, pelo uso de eventuais ligações genéticas existentes entre os locos marcadores e aqueles controladores da característica em questão (em inglês, QTL). A detecção de tais ligações, segundo estes autores, pode ser feita mediante a observação de diferenças significativas entre as médias fenotípicas 
de grupos de indivíduos apresentando diferentes genótipos quanto aos locos marcadores. Dentre as utilizações no melhoramento vegetal, destacaram ainda - monitoramento da introgressão de variabilidade exótica em cultivares comerciais, a seleção precoce na descendência oriunda do cruzamento entre duas linhagens endogâmicas, o estudo da heterose e o melhoramento de linhagens para produção de híbridos, bem como a clonagem de QTL's.

No tocante a espécies autógamas em geral, deve-se salientar que o uso do RFLP tem se deparado com algumas dificuldades, em virtude da base genética mais estreita dessas culturas. Este aspecto é consequência de seu sistema de reprodução, de particularidades do processo de domesticação e, em certos casos, do tipo de melhoramento praticado, utilizando um número limitado de ancestrais. Isso fez com que o nivel de polimorfismo com o RFLP estivesse por vezes aquém do desejado, para fins de melhoramento. Frequentemente, os melhoristas têm sido levados a promover cruzamentos interespecificos, para diminuir esse problema. Esse aspecto é particularmente importante na cultura da soja. Apuya et al. (1988) encontraram um baixo nivel de polimorfismo com RFLP, ao trabalhar exclusivamente com a espécie Glycine max. Em virtude disso, Keim et al. (1990) optaram pelo cruzamento dessa espécie com $\mathrm{G}$. soja, para a obtenção de um maior número de marcas polimórficas. Também na cultura do tomate tem havido preferência pelo uso de cruzamentos interespecíficos para a detecção de locos polimórficos de RFLP. Na realidade, nessas culturas, é comum mesmo haver uma aparente contradição entre a variabilidade morfológica (em geral alta) e a de origem molecular. Halward et al. (1994) apontaram que a razão para tal seria o número relativemente pequeno de locos controladores de características morfológicas. Estes autores, para o uso do RFLP em amendoim, também lançaram mão de cruzamentos interespecíficos (Arachis stenosperma $\times A$. cardenasii; $A$. duranensis $\times$ A. diogoi). 
Até mesmo na cultura do sorgo, na qual a sintenia com o milho permite a utilização de várias marcas já estabelecidas, Bennetzen \& Melake-Berhan (1994) reportaram a necessidade do cruzamento de raças bem contrastantes (de origem africana e chinesa), para obtenção de um nível mínimo de polimorfismo, para a construção de um mapa de ligação.

A cultura do arroz no Brasil também apresenta, segundo Rangel \& Neves (1995b), uma base genética estreita. Segundo esses autores, a grande maioria das cultivares remonta a sete ancestrais. Este aspecto pode limitar a utilização extensiva do RFLP nesta cultura, no país.

Apesar das considerações levantadas, deve-se salientar que o RFLP ainda é a técnica de marcação molecular mais utilizada em espécies autógamas, de uma maneira geral. A partir da década de 1990, no entanto, novas técnicas de marcação molecular têm se mostrado promissoras para uso extensivo nessas culturas, pela maior facilidade de geração ou pelo maior polimorfismo. Estas novas metodologias fazem uso da reação em cadeia da enzima polimerase (processo esse abreviado por PCR), que é um dos principais fatores da simplicidade dessas técnicas. Isso se deu graças à descoberta de uma forma variante dessa enzima, encontrada em bactérias termófilas, e que tolera altas temperaturas (Ferreira \& Grattapaglia, 1996). Com isso, pela alternância de diferentes temperaturas, ciclos de desnaturação, anelamento e extensão do DNA, é possível a geração de milhões de cópias de segmentos específicos, os quais podem ser facilmente visualizados por eletroforese. Burr (1994), em relação ao RFLP, aponta as seguintes vantagens dos métodos baseados em PCR:

a) evita o uso de radioisótopos, pois os produtos de amplificação são discriminados diretamente por eletroforese;

b) não há necessidade do uso de "Southern Blot". 
c) a manutenção e distribuição de sondas, processo oneroso e tido como fonte de eventuais falhas do método, não são necessárias;

d) a divulgação de marcas conseguidas é feita tão-somente pela publicação das sequências dos "primers", de tal maneira que os laboratórios podem sintetizar suas próprias sequências de nucleotídeos.

Dentre os marcadores que fazem uso de PCR, o mais utilizado em plantas, atualmente, é o RAPD, que corresponde à geração de polimorfismo com a amplificação de segmentos de DNA a partir de "primers" de sequência aleatória (Williams et al., 1990). Trata-se de "primers" relativamente pequenos, facilitando a possibilidade de homologia em diferentes pontos do genoma. Se esta homologia (sítio de iniciação) ocorrer duas vezes em um mesmo segmento de DNA, em direções opostas, então a cada ciclo da PCR são amplificadas cópias desse segmento, exponencialmente, cujo padrão pode ser visto em eletroforese. O polimorfismo pode ser resultante da alteração da sequência de bases de um dos sítios, fazendo com que o segmento não seja amplificado. Outras fontes possiveis de polimorfismo são a inserção ou deleção de segmentos dentro dos fragmentos amplificados. Na maioria das vezes, contudo, o polimorfismo é identificado pela ocorrência ou não da amplificação e, em virtude disso, diz-se que a herança associada ao marcador é dominante.

A técnica de RAPD tem mostrado um nivel de polimorfismo maior que o do RFLP, embora Kochert (1994) tenha apontado que esta última técnica apresenta potencial de identificar polimorfismo em um maior espectro quanto ao tamanho dos fragmentos, de até $20 \mathrm{~kb}$. Este autor comentou que uma maneira de aumentar o polimorfismo na RAPD, embora não muito utilizada, seria a de digestão de produtos amplificados por PCR, monomórficos, utilizando enzimas de restrição. Diferenças na sequência de bases em sítios de restrição poderiam assim ser detectadas. 
Indubitavelmente, além da herança dominante, um dos fatores mais limitantes da técnica de RAPD é sua alta sensitividade às condições de reação, fazendo por vezes com que o polimorfismo não seja superior ao do RFLP (Michelmore et al., 1994). Essa baixa repetibilidade faz com que a técnica seja mais adequada a estudos de filogenia e de diversidade, do que propriamente à detecção de poligenes. Michelmore et al. (1994) relataram a viabilidade da técnica de SCAR (do inglês "Sequence Characterized Amplified Region") para diminuir esse problema em alface. Este método, a partir da obtenção e sequenciamento de fragmentos amplificados, utiliza "primers" maiores (24 mers) fazendo com que um único loco seja amplificado, com alta repetibilidade, e por vezes levando a um padrão codominante de herança.

Uma técnica mais recente de marcação molecular, bastante promissora no melhoramento vegetal, particularmente em espécies autógamas de base genética estreita, é a do polimorfismo em comprimento de fragmentos amplificados (AFLP) (Zabeau, 1993). A técnica é detalhadamente descrita por Ferreira \& Grattapaglia (1995), è é realizada basicamente em 4 etapas:

1) digestão do DNA com duas enzimas de restrição, sendo uma relativa a um sítio de restrição de ocorrência rara, e outra a um sítio frequente;

2) ligação de adaptadores específicos de cada enzima de restrição aos terminais dos fragmentos obtidos. Estes adaptadores contêm sequências complementares a "primers" conhecidos;

3) amplificação dos fragmentos;

4) separação dos fragmentos amplificados em gel de alta resolução (de acrilamida, por exemplo).

Os "primers" utilizados possuem de 1 a 3 bases arbitrárias na extremidade 3', fazendo com que só sejam amplificados aqueles fragmentos onde houver homologia. Além disso, somente os "primers" relativos à enzima de 
restrição de corte raro têm marcação radioativa. Dessa forma, apenas os fragmentos de tamanho intermediário (com um sítio raro em uma extremidade e um frequente na outra), os quais promovem uma boa resolução, são detectados, evitando um número excessivo de bandas. Os fragmentos com sítio raro em ambas as extremidades migram muito pouco no gel.

O polimorfismo com o AFLP tem como origem diferenças quanto aos sítios de restrição e quanto à complementariedade da sequência arbitrária das bases adicionais nos "primers" a regiões do DNA. Variando estas bases (em número e sequência), e variando as enzimas de restrição, um alto nível de diferenciação molecular é possível. Espera-se que mesmo em espécies de baixa variabilidade, como a soja, um grau satisfatório de polimorfismo seja alcançado. Contudo, os estudos envolvendo a técnica ainda são relativamente escassos. Uma desvantagem sua é a da herança dominante, que impossibilita a detecção de indivíduos heterozigóticos em gerações $F_{2}$ ou retrocruzamentos. Por outro lado, se os materiais sob estudo encontram-se altamente endogâmicos, como é o caso quando se faz uso de linhagens recombinantes (Bailey, 1971; Ellis, 1986), este aspecto é irrelevante. Além disso, se com o tempo a técnica tiver seu protocolo simplicado e barateado, o uso de testes de progênies, obtidas por autofecundação, pode contornar esse problema.

A PCR também pode ser utilizada de maneira a gerar padrões de herança codominante, pela utilização de "primers" flanqueando sequências de DNA repetitivo em tandem (Kochert, 1994). Estas sequências são comuns em organismos eucariotos, e geram polimorfismo pelo diferente número de vezes em que a sequência é repetida. Segundo Kochert (1994), as primeiras sequências identificadas continham de 15 a 75 ntp, e apresentavam um pico de contraste no processo de centrifugação equivalente ao encontrado em regiões de satélites. Assim, essa técnica de marcação passou a ser conhecida como "minisatélites", ainda que a centrifugação nem seja utilizada. Posteriormente, sequências ainda menores foram identificadas, tais como $(G T)_{n}$ 
ou $(C A C)_{n}$, sendo assim denominadas "microsatélites". Uma vez que nem sempre existe uma clara distinção entre ambos, é proposto o termo geral VNTR, cuja sigla em inglês significa "número variável de sequências repetidas em tandem", ou ainda SSR, significando "sequências simples repetidas".

Ferreira \& Grattapaglia (1995) relataram que a visualização dos produtos amplificados deve ser feita em gel de alta resolução, para discriminação de fragmentos contendo diferenças pequenas quanto ao número de cópias repetidas. A técnica vem sendo utilizada já há algum tempo em mamiferos (Julier et al., 1990), mas ainda existem poucos resultados em plantas. No entanto, já há evidências promissoras na cultura da soja (Akkaya et al., 1992), quanto ao polimorfismo e à segregação codominante. Burr (1994) observa que, além do alto nivel de polimorfismo, os marcadores de microsatélites têm se mostrado surpreendentemente estáveis, com uma taxa de mutação estimada em $4,5 \times 10^{-5} \mathrm{em}$ camundongos.

A maior dificuldade do uso de microsatélites é a de obtenção dos "primers" flanqueando as sequências repetidas, a qual necessita de técnicas de sequenciamento. Apesar disso, segundo Burr (1994), o custo desta é dissipado, em virtude do longo prazo em que os "primers" são posteriormente utilizados.

Os marcadores moleculares do tipo SSR apresentam ambas as vantagens de alto polimorfismo e herança codominante, sendo portanto aparentemente adequados para espécies autógamas cultivadas onde há pequena variabilidade, e sob qualquer nivel de endogamia durante um programa de melhoramento genético.

Um aspecto crucial da detecção de QTL's através de marcadores genéticos é a necessidade de que a população sob estudo esteja em desequilíbrio de ligação, caso contrário os alelos dos locos marcadores e dos poligenes terão segregação independente, e estes últimos não serão 
detectados. Tanksley (1993) comenta que em virtude disso é necessária a geração de populações especiais, como retrocruzamentos, $F_{2}, F_{3}$, etc. Sendo disponíveis várias marcas codominantes, ainda segundo este autor, é possível elaborar contrastes entre o heterozigoto (com relação ao loco marcador) e um dos homozigotos, para cada marca em separado. Este enfoque, denominado análise por ponto, permite estimar o efeito de QTL's eventualmente ligados às marcas, caso os contrastes sejam estatisticamente significativos. Edwards et al. (1987) propuseram particionar a variação entre genótipos de uma mesma marca em dois contrastes ortogonais. Um deles, entre a média fenotípica dos dois homozigotos, estimaria o dobro do efeito aditivo associado ao QTL; enquanto que o restante, entre o heterozigoto e a média dos homozigotos, estimaria o efeito de dominância. Na realidade, o primeiro contraste é equivalente a testar o ajustamento a um modelo de regressão linear simples, sendo que a estimativa do coeficiente de regressão na realidade estima o efeito médio de um dos alelos (Falconer \& MacKay, 1996) do QTL.

Uma desvantagem da análise por ponto é a de que ela tende a subestimar os efeitos aditivo e de dominância, devido à ocorrência de recombinação entre o QTL em questão e a marca a ele ligado. Lander \& Botstein (1989) propuseram uma metodologia, chamada de análise por intervalo, que, ao levar em conta todas as marcas simultaneamente, evita o viés gerado pela recombinação. Utilizando uma função de verossimilhança que pressupõe distribuição normal para os efeitos ambientais dentro de cada classe genotípica, e que leva em conta a probabilidade de que um dado indivíduo apresente determinado número de um dos alelos do loco marcador, os autores mostraram ser possível estimar os efeitos associados a cada QTL, bem como sua posição no mapa genético, pelo uso do método da máxima verossimilhança. Haley \& Knott (1992) também propuseram um método de mapeamento de QTL's, baseado em modelos de regressão, e recentemente outros autores têm 
refinado essas técnicas, levando em conta diferentes características simultaneamente (Jiang \& Zeng, 1995).

Atualmente já são disponiveis numerosos mapas genéticos contendo marcadores moleculares em diversas espécies autógamas. A maior parte desses mapas são relativos a marcas do tipo RFLP, em virtude da maior utilização dessa técnica até o momento. Na cultura da cevada, os atuais mapas são principalmente baseados em quatro populações segregantes, sendo que três deles constituídos de linhagens haplóides duplicadas e uma de indivíduos $F_{2}$ (Kleinhofs \& Kilian, 1994). Levando em conta que tais mapas muitas vezes identificam os mesmos locos, esses autores acreditam que contenham ao todo 581 marcadores distintos, e que esse número vem crescendo continuamente.

Na cultura da alface, Michelmore et al. (1994) reportaram que isoenzimas não são utilizadas extensivamente. Existem 42 sistemas enzimáticos relatados, com cerca de 70 locos putativos, mas que dos quais somente se observou polimorfismo em 22. Quanto ao RFLP, o uso de 1900 clones aleatórios de c-DNA propiciaram a deteç̧ão de 143 locos, enquanto que 400 clones genômicos identificaram 9 adicionais, totalizando 152. Os autores ressaltaram ainda a disponibilidade de 130 locos de RAPD.

Em amendoim, Halward et al. (1994) apontam que o mapa de RFLP disponivel atualmente cobre um comprimento total de $140 \mathrm{cM}$, com uma distância média de $20 \mathrm{cM}$ entre marcas, espalhadas em 12 grupos de ligação. Futuramente, é esperado que esse valor diminua para 10 , o qual corresponde ao número básico de cromossomos do genoma da espécie (4x = 40).

Quanto à cultura do feijão, o mapa disponivel compreende 227 locos de RFLP, e foi baseado em um retrocruzamento de um material meso-americano com outro de origem andina, sendo o primeiro o genitor recorrente (Vallejos, 1994). Nodari et al. (1993) apresentaram, também para o 
feijão, um mapa construído a partir da geração $F_{2}$ derivada do cruzamento entre uma cultivar brasileira e uma linhagem desenvolvida no CIAT, cobrindo $827 \mathrm{cM}$, e contendo 143 marcadores, em 15 grupos de ligação, envolvendo locos de RFLP, RAPD, isoenzimáticos e marcadores morfológicos e de resistência a doenças.

A Universidade de Comell, nos Estados Unidos, é um dos principais centros envolvidos na elaboração de mapas moleculares para a cultura do arroz (Tanksley, 1994). Atualmente dispõe-se de cerca de 600 locos, espalhados em 1222cM. Este autor observou que um problema frequente na construção de tais mapas é a subestimação da taxa de recombinação, em virtude do uso de cruzamentos interespecíficos (no caso, Oryza sativa $\times 0$. longistaminata), a qual pode corresponder a apenas $70 \%$ daquela no material adaptado. Assim, estima-se que tal mapa cubra na realidade $1750 \mathrm{cM}$ no germoplasma cultivado.

Estudos preliminares com a soja mostraram um baixo nível de polimorfismo quanto a sítios de restrição (Apuya et al., 1988). Isso fez com que Keim et al. (1990) laçassem mão de um cruzamento interespecífico para diminuir esse problema. A partir de uma população $F_{2}$ obtida de um cruzamento envolvendo Glycine max e G. soja, foi possível identificar 26 grupos de ligação, totalizando cerca de $1200 \mathrm{cM}$. Shoemaker (1994) apresentou um mapa integrado, contendo, além de locos de RFLP, locos isoenzimáticos e marcadores genéticos clássicos, com 24 grupos de ligação, cobrindo cerca de $2900 \mathrm{cM}$. No caso específico do RFLP, Keim et al. (1990) reportaram ainda que cerca de $10 \%$ dos locos marcadores apresentaram um padrão de herança dominante, possivelmente em virtude de adições ou deleções de bases em um dos genitores.

Dentre as espécies autógamas, o tomate é talvez a que tem sofrido um mais extensivo mapeamento molecular, sendo o uso de cruzamentos 
interespecíficos frequente. Tanksley (1994) apresentou a disponibilidade de mais de 1000 locos marcadores, cobrindo um total de $1276 \mathrm{cM}$.

Para a cultura do trigo, Hart (1994) ressaltou que um catálogo completo sobre locos marcadores conhecidos é publicado a cada 5 anos no Proceedings of the International Wheat Genetics Symposium, sendo que um suplemento é publicado anualmente. $O$ autor comentou que os mapas atuais contêm cerca de uma marca a cada $20 \mathrm{cM}$, cobrindo cerca de $3000 \mathrm{cM}$, e que este valor parece estar ainda consideravelmente aquém do tamanho total do genoma que se estima em trigo.

A identificação de locos marcadores em poliplóides, como é o caso do trigo ou da aveia, traz dificuldades adicionais, em virtude do tamanho do genoma e da maior complexidade da herança. Esse aspecto contribui para a procura de espécies selvagens diplóides. Em aveia, O'Donoughe et al. (1994) relataram o uso dos cruzamentos Avena atlantica $\times A$. hirtula, e $A$. strigosa $\times A$. wiestii. Segundo este mesmo autor, mesmo espécies selvagens hexaplóides têm sido utilizadas, como no cruzamento $A$. byzantina $\times A$. sativa. Nesse caso, é comum usar aneuplóides para o mapeamento, como nulissômicos $(2 n-2=40)$, que permitem detectar marcadores em cromossomos específicos, e ditelossômicos $(2 \mathrm{n}-\mathrm{tt}=40+\mathrm{tt})$, que permitem identificar o braço cromossômico que contem o loco marcador em questão.

\subsection{Desequilíbrio de Ligação em Autógamas}

Como mencionado anteriormente, para que os marcadores moleculares possam contribuir em estudos de herança e no melhoramento, é necessário que a população esteja em desequilíbrio de ligação, caso contrário a 
probabilidade de ocorrência de determinada classe de marcador seria independente da segregação dos alelos para a característica de interesse.

Falconer \& MacKay (1996) apresentaram um critério para a quantificação do desequilíbrio de ligação, baseado na diferença dos produtos das frequências dos gametas com os locos em associação e repulsão, gametas esses dos genitores que deram origem à geração atual. Assim, o desequilíbrio em uma população constituída a partir da mistura de uma população com frequências para certos alelos $A$ e $B$ iguais a $100 \%$, com outra, com frequências alélicas para os alelos a e b iguais a $100 \%$, poderia ser dado por:

$$
D=f(A B) f(a b)-f(A b) f(a B)
$$

em que f denota a frequência do gameta correspondente contendo os alelos $A$, a, $B$ e b. $O$ desequilíbrio de ligação também pode ser mensurado da seguinte forma:

$$
D=f(A B)-f(A) f(B)
$$

$f(A)$ e $f(B)$ correspondendo às frequências dos alelos $A$ e $B$, respectivamente.

Em plantas autógamas, quando a frequência de recombinação é de $50 \%$ entre 2 locos (independência), o desequilíbrio de ligação será sempre nulo nas geraçōes de autofecundação a partir do cruzamento entre duas linhagens contrastantes. No entanto, quando os locos estão ligados, ocorrerá desequilíbrio de ligação, e este diminuirá em uma taxa inferior àquela observada em plantas alógamas, em virtude do sistema de reprodução. $\mathrm{O}$ desequilíbrio de ligação em $\mathrm{F}_{2}$ é dado por:

$$
D_{F 2}=0,25(1-2 r)
$$

em que $r$ é a frequência de recombinação entre dois locos quaisquer $A$ e $B$. $A$ frequência de gametas de plantas $F_{2}$ do tipo $(A B)$, vindas de um cruzamento 
entre linhagens em fase de associação para os locos A e B, conforme Bearzoti ${ }^{1}$, é dada por:

$$
f(A B)_{F 2}=\frac{(1-2 r)}{2}-r\left[\frac{(1-r)}{2}\right]^{2}+r\left[\frac{r}{2}\right]^{2}
$$

e assim o desequilíbrio de ligação em $F_{3}$ é dado por:

$$
D_{F 3}=f(A B)_{F 2}-0,25
$$

Já a frequência de gametas do tipo $(A B)$ em plantas $F_{3}$ é dada por:

$$
\begin{aligned}
& f(A B)_{F 3}=f(A B)_{F 2}-4 r\left\{\left[\frac{(1-r)}{2}\right]^{4}+\left[\frac{r}{2}\right]^{4}\right\}+ \\
& +8 r\left[\frac{(1-r)}{2}\right]^{2}\left[\frac{r}{2}\right]^{2}
\end{aligned}
$$

e o desequilíbrio em $F_{4}$ :

$$
D_{F 4}=f(A B)_{F 3}-0,25
$$

A Tabela 6 ilustra o comportamento do desequilíbrio de ligação com o avanço dessas geraçōes, em diferentes frequências de recombinação. Nota-se que, uma vez que haja ligação, o desequilíbrio de ligação dissipa-se com uma taxa lenta, tendo um limite diferente de zero. Este aspecto pode se constituir em uma vantagem no tocante à utilização de marcadores moleculares no melhoramento de plantas autógamas.

\subsection{Seleção Assistida Por Marcadores}

As técnicas de marcação molecular, além de aprimorar o estudo da natureza genética de características quantitativas pela detecção,

\footnotetext{
${ }^{1}$ BEARZOTI, E. Dados não publicados, 1995.
} 
quantificação de efeitos e mapeamento de QTL's, podem ser utilizadas para assistir programas de seleção recorrente.

Um dos primeiros relatos sobre a prática de seleção baseada na frequência de locos marcadores foi o de Stuber et al. (1982). Estes autores dispunham de uma população de milho, obtida de uma cultivar de polinização aberta, e uma outra, resultante da prática de 10 ciclos seletivos na primeira população, para produtividade de grãos. Eles tinham conhecimento de alterações significativas na frequência de alelos de 8 locos aloenzimáticos, na população melhorada. Para verificar se a seleção baseada exclusivamente na informação molecular seria eficiente, os autores selecionaram plantas da primeira população, de maneira a gerar frequências virtualmente idênticas àquelas da população submetida aos 10 ciclos de seleção, e compararam as três mediante um delineamento experimental, com relação à produtividade. Foi verificado que de fato a seleção baseada em locos aloenzimáticos possibilitou o incremento tanto na produtividade de grãos, como no número de espigas, e equivalentemente a 1,5 a 2 ciclos de seleção utilizando irmãos germanos. Não houve como estabelecer, contudo, se as alterações ocorridas com tais características foram devidas a ligações com poligenes, ou à participação das aloenzimas em suas rotas metabólicas.

O uso de marcadores moleculares pode ser feito para diminuir o número de gerações de retrocruzamento para a introgressão de alelos de materiais exóticos. Trata-se de um método frequentemente praticado no melhoramento de plantas autógamas e de linhagens visando a obtenção de híbridos. Tanksley et al. (1981), a partir de retrocruzamentos entre um híbrido de Lycopersicon esculentum e Solanum pennellii e o primeiro genitor, construíram um índice de heterozigosidade média com relação a 12 locos isoenzimáticos, previamente testados, e que haviam mostrado polimorfismo entre os genitores. Observaram correlações positivas entre os valores do indice e os de características de natureza contínua dos genitores. Quanto menor a 
heterozigosidade, maior foi a semelhança com Lycopersicon esculentum, o genitor recorrente. Desse modo, os autores apontaram que marcadores moleculares permitiriam a seleção precoce ainda em fase de "seedling", aumentando a eficiência das gerações de retrocruzamento, pela recuperação mais rápida das características do genitor recorrente.

Beckman \& Soller (1986), discutindo métodos pelos quais a seleção assistida por marcadores moleculares poderia ser praticada, apontaram seu potencial na introgressão de QTL's de materiais doadores a cultivares comerciais, monitorada por marcadores, o que contornaria a dificuldade (ou inviabilidade) de identificação dos efeitos isolados dos QTL's. No tocante ao melhoramento de plantas autógamas, esses mesmos autores ressaltaram a possibilidade de otimização do método genealógico, pela seleção de indivíduos ou linhagens em gerações tão precoces como $F_{2}$. Essa seleção seria baseada no número de alelos dos locos marcadores, apresentado pelos indivíduos, mostrando ligações favoráveis com QTL's. O avanço de gerações de autofecundação desses indivíduos superiores permitiria um segundo estágio de seleção, agora baseado na média fenotípica de linhagens, avaliadas com repetições e parcelas experimentais de tamanho satisfatório. Esperar-se-ia, com isso, um aumento no ganho com a seleção, devido à avaliação precoce anterior, a qual, quando baseada tão somente no fenótipo dos indivíduos, não permite uma identificação eficiente daqueles superiores, em presença de dominância e baixa herdabilidade no sentido restrito.

Nienhuis et al. (1987) verificaram associações significativas entre locos de RFLP e locos controladores da síntese de 2-Tridecanona, que confere resistência a insetos em tomate. Para tanto, testaram inicialmente 36 locos de RFLP, espaçados em cerca de 10 a $20 \mathrm{cM}$ ao longo do genoma, em uma geração $F_{2}$ obtida de um cruzamento entre Lycopersicon esculentum e Lycopersicon hirsutum. Contrastes lineares e quadráticos foram feitos entre as três classes genotípicas, nas diferentes marcas, para detectar efeitos de QTL's 
e estudar sua ação gênica. Para aqueles locos significativos, construiu-se um modelo de regressão múltipla, para prever o comportamento com relação à síntese de 2-Tridecanona. Uma vez que a correlação entre valores preditos e observados foi alta $(0,62)$, os autores apontaram que a seleção indireta, baseada nos locos marcadores, seria eficaz.

A seleção assistida por marcadores também tem sido sugerida no melhoramento animal (Smith \& Simpson, 1986). Kashi et al. (1990) apresentaram o potencial do método para a seleção de touros sem a necessidade de testes de progênies. Para tanto, apresentam um esquema baseado na classificação genotípica, quanto a locos marcadores, de um touro sabidamente de elite e de suas filhas. A partir destas, seria possivel detectar QTL's associados à produção de leite, e assim netos do touro-elite poderiam ser selecionados tão-somente a partir de seus genótipos quanto aos locos marcadores. Eventualmente, a técnica poderia ser praticada com os netos ainda em estágio embrionário.

Kashi et al. (1990) desenvolveram expressões para quantificar o número de associações QTL-marcador detectadas no touro que estariam igualmente presentes nos netos, bem como para o ganho com a seleção esperado. Neste desenvolvimento, os autores consideraram QTL's de mesmo efeito, e frequências alélicas intermediárias. Através de avaliações numéricas, concluíram que a seleção assistida por marcadores pode ser efetiva, desde que a natureza dos marcadores seja polialélica, ou com a ocorrência de blocos de ligação contendo marcas dialélicas. Também foi observado que a vantagem da técnica seria consideravelmente maior em condições de baixa herdabilidade. Observou-se que sua eficiência em relação à prática convencional cai aproximadamente pela metade quando as frequências dos QTL's aumentam de um intervalo entre 0,5 a 0,8 para valores em torno de 0,9 .

Talvez um dos trabalhos de maior impacto no desenvolvimento de métodos de seleção assistida por marcadores, para o 
melhoramento de plantas, seja o de Lande \& Thompson (1990). Esses autores propuseram que a técnica fosse aplicada mediante um índice de seleção, que reunisse a informação fenotípica das unidades de seleção com aquela obtida de marcadores moleculares. O método é semelhante ao praticado no melhoramento animal, quando se usa a informação de parentes, aos quais não se atribui nenhum valor econômico para a elaboração do índice (Falconer \& MacKay, 1996).

Um dos fatores cruciais para o sucesso da técnica, segundo Lande \& Thompson (1990), é a ocorrência de um número razoável de marcas polimórficas ao longo do genoma, de maneira a detectar satisfatoriamente os efeitos dos QTL's. Levando em conta fatores que afetam o nivel de desequilíbrio de ligação, como a hibridação e a deriva genética, os autores obtiveram expressões para se determinar um número mínimo de locos marcadores para detectar associações substanciais com QTL's (Tabela 7). Observa-se que, para um genoma de 10 Morgans, um número mínimo de 30 marcadores é necessário para detectar uma fração satisfatória de QTL's, na primeira geração após uma hibridação entre duas linhagens endogâmicas. Após 5 gerações, esse número salta para 110 marcadores em plantas alógamas, e 49 em autógamas. Aparentemente, este seria um fator vantajoso para as espécies autógamas (em relação às alógamas), compensando em parte a menor variabilidade nelas presente, em geral.

O indice proposto por Lande \& Thompson (1990) é dado

por:

$$
l_{i}=b_{Z} Z_{i}+b_{M} M_{i}
$$

em que $Z_{i}$ é o fenótipo da unidade de seleção $i ; M_{i}$ é a soma dos efeitos médios de um dos alelos associados a diferentes marcas, multiplicados pelo número de cópias desses alelos presentes na unidade de seleção i ( $M_{i}$ também é chamado de escore molecular); e $b_{z}$ e $b_{M}$ são os coeficientes ou pesos dados a essas 
características. Os valores relativos conferidos a esses coeficientes, que maximizam o ganho com a seleção, são tais que satisfazem a seguinte relação matricial (Baker, 1986; Lande \& Thompson, 1990):

$$
P \mathbf{b}=\mathbf{G} \mathbf{d}
$$

na qual $\mathbf{P}$ é a matriz de variâncias e covariâncias fenotípicas associadas à característica quantitativa em questão e ao escore molecular, $\mathbf{b}^{\prime}=\left[b_{Z} b_{M}\right]$; $\mathbf{G}$ é a matriz de variâncias e covariâncias genéticas de natureza aditiva e $\mathbf{d}$ é um vetor de pesos econômicos relativos, conferidos aos valores genéticos da característica em questão e ao escore molecular. Como este não tem nenhum valor econômico intrínseco, então:

$$
\mathbf{d}^{\prime}=\left[\begin{array}{ll}
1 & 0
\end{array}\right]
$$

Parametricamente, ao escore molecular $M_{i}$ não estão associados efeitos ambientais, ao contrário do fenótipo $Z_{i}$. Sendo assim, as variâncias fenotípica e genética relativas aos marcadores são idênticas (representadas por $\sigma_{M}^{2}$ ), e correspondem a uma maior ou menor fração da variância genética aditiva da característica. Da mesma forma, a covariância entre o escore e o fenótipo, bem como entre o primeiro e o valor genético dos indivíduos, corresponde a esse componente da variância genética relativo aos marcadores:

$$
V\left(M_{i}\right)=\operatorname{Cov}\left(Z_{i}, M_{i}\right)=\operatorname{Cov}\left(g_{i}, M_{i}\right)=\sigma_{M}^{2}
$$

em que $\mathrm{V}(\cdot)$ e $\operatorname{Cov}(\cdot)$ denotam variância e covariância, respectivamente, e $g_{i}$ corresponde ao valor genético do indivíduo ou da unidade seleção i. Assim:

$$
\begin{aligned}
& \mathbf{P}=\left[\begin{array}{ll}
\sigma_{Z}^{2} & \sigma_{M}^{2} \\
\sigma_{M}^{2} & \sigma_{M}^{2}
\end{array}\right] \\
& \mathbf{G}=\left[\begin{array}{ll}
\sigma_{A}^{2} & \sigma_{M}^{2} \\
\sigma_{M}^{2} & \sigma_{M}^{2}
\end{array}\right]
\end{aligned}
$$


em que $\sigma_{z}^{2}$ é a variância fenotípica associada à característica em questão, e $\sigma_{A}^{2}$ sua variância genética de natureza aditiva. Substituindo (2.12) e as matrizes (2.13) na relação (2.10) tem-se:

$$
\begin{gathered}
{\left[\begin{array}{l}
b_{z} \\
b_{M}
\end{array}\right]=\left[\begin{array}{ll}
\sigma_{z}^{2} & \sigma_{M}^{2} \\
\sigma_{M}^{2} & \sigma_{M}^{2}
\end{array}\right]^{-1}\left[\begin{array}{ll}
\sigma_{A}^{2} & \sigma_{M}^{2} \\
\sigma_{M}^{2} & \sigma_{M}^{2}
\end{array}\right]\left[\begin{array}{l}
1 \\
0
\end{array}\right]=} \\
=\left[\begin{array}{ll}
\sigma_{z}^{2} & \sigma_{M}^{2} \\
\sigma_{M}^{2} & \sigma_{M}^{2}
\end{array}\right]^{-1}\left[\begin{array}{l}
\sigma_{A}^{2} \\
\sigma_{M}^{2}
\end{array}\right]=\frac{1}{\sigma_{Z}^{2} \sigma_{M}^{2}-\sigma_{M}^{4}}\left[\begin{array}{cc}
\sigma_{M}^{2} & -\sigma_{M}^{2} \\
-\sigma_{M}^{2} & \sigma_{Z}^{2}
\end{array}\right]\left[\begin{array}{l}
\sigma_{A}^{2} \\
\sigma_{M}^{2}
\end{array}\right]= \\
=\frac{1}{\sigma_{Z}^{2} \sigma_{M}^{2}-\sigma_{M}^{4}}\left[\begin{array}{c}
\sigma_{M}^{2} \sigma_{A}^{2}-\sigma_{M}^{4} \\
-\sigma_{M}^{2} \sigma_{A}^{2}+\sigma_{Z}^{2} \sigma_{M}^{2}
\end{array}\right]
\end{gathered}
$$

E assim:

$$
\left[\begin{array}{l}
b_{Z} \\
b_{M}
\end{array}\right]=\frac{1}{\sigma_{Z}^{2}-\sigma_{M}^{2}}\left[\begin{array}{l}
\sigma_{A}^{2}-\sigma_{M}^{2} \\
\sigma_{Z}^{2}-\sigma_{A}^{2}
\end{array}\right]
$$

A partir de (2.14), a seguinte relação pode ser obtida:

$$
\frac{b_{M}}{b_{Z}}=\frac{\sigma_{Z}^{2}-\sigma_{A}^{2}}{\sigma_{A}^{2}-\sigma_{M}^{2}}
$$

Multiplicando e dividindo (2.15) por $\sigma_{\mathrm{A}}^{2}$, tem-se:

$$
\frac{b_{M}}{b_{z}}=\frac{\frac{1}{h^{2}}-1}{1-p}
$$

em que $\mathrm{p}$ refere-se à proporção da variância genética aditiva explicada pelos marcadores e $h^{2}$ é a herdabilidade no sentido restrito. Como os coeficientes do indice (2.9) têm apenas um valor relativo entre si, pode-se fazer $b_{z}=1$, como sugerem Gimelfarb \& Lande (1994a), e assim:

$$
b_{M}=\frac{\frac{1}{h^{2}}-1}{1-p}
$$


Conforme se observa pela expressão (2.17), o peso relativo conferido ao escore molecular será tanto maior quanto menor for $\mathrm{h}^{2}$ e/ou maior for $p$. A eficiência do uso do índice (2.9), em relação à utilização somente da informação fenotípica, pode ser quantificada como uma relação entre os ganhos esperados com a seleção utilizando cada um dos dois sistemas. Para tamanhos de amostra muito elevados, Lande \& Thompson (1990) mostraram que essa relação, aqui denotada por Es, corresponde a:

$$
E s=\sqrt{\frac{p}{h^{2}}+\frac{(1-p)^{2}}{1-h^{2} p}}
$$

A Tabela 8 apresenta valores de Es, para diferentes magnitudes de $h^{2}$ e de $p$. Observa-se que Es aumenta com a diminuição de $h^{2}$ e/ou o aumento de p. No melhoramento vegetal de espécies com mapas moleculares saturados, é razoável admitir a ocorrência de valores de $p$ tão altos como 0,8 , por exemplo. Nesses casos, para características de baixa herdabilidade, é esperada uma alta eficiência da seleção assistida por marcadores (com $h^{2}=0,15$, essa eficiência é de 2,32, conforme Tabela 8). Também é possivel mostrar que Es aumenta à medida que $h^{2}$ diminui e/ou $p$ aumenta, pelo cálculo dos seguintes limites:

$$
\begin{gathered}
\lim _{p \rightarrow 1} \sqrt{\frac{p}{h^{2}}+\frac{(1-p)^{2}}{1-h^{2} p}}=\sqrt{\frac{1}{h^{2}}} \\
\lim _{h^{2} \rightarrow 0} \sqrt{\frac{p}{h^{2}}+\frac{(1-p)^{2}}{1-h^{2} p}}=\infty
\end{gathered}
$$

Para uma certa herdabilidade no sentido restrito, a máxima eficiência da seleção assistida por marcadores moleculares consiste portanto na raiz do inverso de seu valor, conforme a primeira expressão em (2.19). Por outro lado, Es diminui à medida que $h^{2}$ aumenta e/ou $p$ diminui: 


$$
\begin{gathered}
\lim _{p \rightarrow 0} \sqrt{\frac{p}{h^{2}}+\frac{(1-p)^{2}}{1-h^{2} p}}=1 \\
h^{2} \rightarrow 1 \sqrt{\frac{p}{h^{2}}+\frac{(1-p)^{2}}{1-h^{2} p}}=1
\end{gathered}
$$

É interessante notar que, a julgar pelas expressões em (2.20), a eficiência da seleção assistida por marcadores não é nunca inferior a 1, ou seja, o uso do índice (2.9) ocasiona um ganho esperado com a seleção nunca inferior àquela praticada baseando-se estritamente na informação fenotípica, pelo menos do ponto de vista teórico. Em uma situação real, no entanto, como $h^{2}$ e $p$ terão de ser estimados, os valores observados para a eficiência relativa serão, em média, sempre inferiores àqueles previstos em (2.18), conforme apontado por Baker (1986). Este autor mostrou que, se os coeficientes de um índice de seleçāo são obtidos a partir de estimativas de componentes de variância e covariância, o ganho esperado com a seleção combinada é sempre menor do que o esperado com o índice ótimo (com valores paramétricos), e esse fato torna-se mais acentuado à medida que o tamanho da amostra para obtenção dessas estimativas diminui. Em virtude disso, a eficiência (realizada) da seleção assistida por marcadores pode ser mesmo inferior a 1.

Baker (1986) apresentou alguns critérios para dimensionar o tamanho de amostras quando se utiliza índices de seleção. $O$ primeiro baseia-se no intervalo de confiança para $\sigma^{2}$, uma vez que estimativas de componentes de variância são necessários para estimar os coeficientes de um índice de seleção. O autor observou que, sob normalidade, são necessários cerca de 400 elementos na amostra para que a variância amostral esteja no intervalo $\sigma^{2} \pm$ $0,1 \sigma^{2}$, com $95 \%$ de probabilidade. Isso sugere a necessidade de se trabalhar com amostras grandes. 
Um segundo critério é o apresentado por Hill \& Thompson (1978), que apontaram que, se as estimativas de variâncias e covariâncias forem suficientemente imprecisas, as correlaçōes (comuns ou parciais) podem assumir valores fora do intervalo $[-1,1]$. Estes autores mostraram que, para uma herdabilidade de 0,125 , este problema só ocorrerá com uma probabilidade suficientemente baixa, na utilização de índices de seleção, com amostras grandes, de cerca de 40 grupos genéticos (progênies, por exemplo), cada qual com 20 indivíduos.

Baker (1986) apresentou ainda um enfoque, originalmente proposto por W. G. Cochran ${ }^{1}$, fornecendo pelo menos dois critérios a mais. Este enfoque baseia-se na correlação existente entre o valor genético dos indivíduos e seus valores para $o$ índice de seleção, utilizando estimativas (aqui representado por $r_{s}$ ) e utilizando valores paramétricos $\left(r_{p}\right)$, caso estes fossem conhecidos. Segundo Baker (1986), Cochran demonstrou que, sob distribuição normal multivariada, para que a diferença $r_{P}-r_{s}$ seja (em módulo) menor que $5 \%$, então a amostra deve conter mais que 45 elementos, considerando uma $r_{P}$ $>0,7$, e 2 características no índice. Utilizando este mesmo enfoque, foi também possivel demonstrar que o ganho médio com o índice de seleção, usando estimativas, não supera nunca aquele utilizando valores paramétricos. Para que a razão entre ambos seja maior que $90 \%$, então os tamanhos de amostra devem ser, no mínimo, conforme apresentados na Tabela 9. São valores relativamente pequenos, e assim pode-se dizer que, a julgar por estes dois últimos critérios, não se justificariam tamanhos de amostra muito elevados quando do uso de índices de seleção.

A seleção assistida por marcadores envolve duas características (a fenotípica e a molecular), mas o número de parâmetros estimados das matrizes (2.13) é menor, em relação a um índice de seleção

\footnotetext{
${ }^{1}$ COCHRAN, W. G. Improvement by means of selection. In: Proceedings of the 2nd Berkeley Sympsium of Mathematics, Statistics and Probability, 1951, p.449.
} 
convencional, em virtude da relação (2.12). Para melhor compreender o significado de $r_{p}$ na seleção assistida por marcadores, é conveniente expressála em termos de parâmetros como $h^{2}, p$ ou $\sigma_{M}^{2}$. Para tanto, tem-se que:

$$
r_{P}=\frac{\operatorname{Cov}\left[I_{i}, g_{i}\right]}{\sqrt{V\left[I_{i}\right] V\left[g_{i}\right]}}
$$

em que $g_{i}$ é o valor genético do indivíduo i. Assim, considerando $b_{z}=1$, tem-se que:

$$
\operatorname{Cov}\left[l_{i}, g_{i}\right]=\operatorname{Cov}\left[b_{M} M_{i}+b_{Z} Z_{i}, g_{i}\right]=b_{M} \sigma_{M}^{2}+\sigma_{A}^{2}
$$

Além disso:

$$
\begin{aligned}
& V\left[l_{i}\right]=b_{M}^{2} \sigma_{M}^{2}+\sigma_{Z}^{2}+2 b_{M} \sigma_{M}^{2}=b_{M} \sigma_{M}^{2}\left(b_{M}+2\right)+\sigma_{Z}^{2} \\
& V\left[g_{i}\right]=\sigma_{A}^{2}
\end{aligned}
$$

Assim, substituindo as expressões (2.22) e (2.23) em (2.21):

$$
r_{p}=\frac{\left[b_{M} \sigma_{M}^{2}+\sigma_{A}^{2}\right]}{\sqrt{\left[b_{M}\left(b_{M}+2\right) \sigma_{M}^{2}+\sigma_{Z}^{2}\right] \sigma_{A}^{2}}}
$$

Dividindo e multiplicando (2.24) por $\sigma_{\mathrm{A}}^{2}$, tem-se:

$$
r_{p}=\frac{\left[b_{M} p+1\right]}{\sqrt{\left[b_{M}\left(b_{M}+2\right) p+\frac{1}{h^{2}}\right]}}
$$

A Tabela 10 apresenta valores de rp para alguns valores de $h^{2}$ e de $p$. Observase que, sob baixa normalidade $\left(h^{2}=0,15\right)$, mesmo com um valor de $p$ tão pequeno como 0,05 , a correlação ip não é baixa (maior que 0,4 ). Com $p=0,20$ esse parâmetro se eleva para 0,547 , com o qual, segundo observado na Tabela 9 , não seriam necessários mais do que algumas poucas dezenas de grupos 
genéticos (progênies, linhagens, etc.) para que a seleção assistida por marcadores tivesse uma eficiência de pelo menos $90 \%$ daquela esperada se os parâmetros fossem conhecidos. O valor desta eficiência, de acordo com a expressão (2.18), seria igual a 1,90. Portanto, mesmo estimando o coeficiente $b_{M}$ do índice (2.9), a seleção assistida por marcadores apresentaria uma eficiência mínima de 1,71 em relação à seleção fenotípica, com um tamanho de amostra reduzido. Trata-se de um resultado que causa surpresa, sugerindo que o critério de Cochran, apresentado por Baker (1986), deva ser submetido à experimentação, para a busca de evidências empíricas que o validem.

Lande \& Thompson (1990) ressaltaram o potencial da seleção assistida por marcadores em situações especiais, como a seleção de indivíduos em estágio juvenil (antes mesmo de manifestar a característica em questão), que poderia preceder outro estágio de seleção utilizando métodos convencionais. Também propuseram a utilização simultânea da informação fenotípica e molecular, entre e dentro de progênies.

No tocante ao potencial da técnica no melhoramento de plantas autógamas, Lande (1992) comentou que se espera pouca eficiência quando a unidade de seleção são linhagens altamente endogâmicas, e com grande número de plantas por linhagem, pois nesse caso a herdabilidade é elevada. Entretanto, o mesmo autor ressaltou que a seleção assistida por marcadores pode ser eficiente, quando praticada em gerações precoces, como $\mathrm{S}_{1}$ e $\mathrm{S}_{2}$, e com um número de plantas por linhagem pequeno, ou mesmo igual a 1. Este aspecto toma-se ainda mais relevante na medida em que a disponibilidade de sementes nas primeiras gerações após um cruzamento entre linhagens endogâmicas, é em geral reduzida. Em plantas alógamas, Lande (1992) também demonstrou que a sua eficiência em programas de seleção recorrente é tanto maior quanto menor for o número de plantas por progênie.

A partir de modelos de regressão de respostas fenotípicas, em função do número de alelos relativos a diferentes marcas, muitos autores 
utilizam o coeficiente de determinação $\left(R^{2}\right)$ para quantificar a fração da variância genética ou fenotípica que é relativa a marcadores moleculares (entre outros, Edwards et al., 1987; Reiter et al., 1992; Gimelfarb \& Lande, 1994a,b). Como visto na expressão (2.16), a proporção $p$ da variância genética aditiva explicada por marcadores é um parâmetro fundamental a ser estimado para a utilização da metodologia proposta por Lande \& Thompson (1990). Como estimador desse parâmetro, o coeficiente de determinação pode não ser o mais indicado, uma vez que as esperanças matemáticas tanto do numerador quanto do denominador do $\mathrm{R}^{2}$ contêm um componente de variância ambiental associado.

A seleção assistida por marcadores tem sido avaliada por alguns autores mediante simulação em computador, a qual é, há muito (Fraser, 1955a,b), reconhecidamente uma ferramenta poderosa para a compreensão de sistemas genéticos. Zhang \& Smith (1992) simularam populações obtidas a partir do cruzamento entre duas linhagens endogâmicas, do qual sucessivas gerações foram avançadas pela troca de gametas ao acaso. Três métodos foram comparados entre si: seleção fenotípica baseada na estimação do valor reprodutivo usando a metodologia de melhor predição linear não-tendenciosa (cuja sigla em inglês é "BLUP") mediante um modelo misto (conhecido como "modelo animal"); uso da informação molecular para estimar o valor reprodutivo conforme sugerido por Goddard (1992); e uma combinação desses dois usando um índice de seleção semelhante ao proposto por Lande \& Thompson (1990). Seus resultados mostraram que esta última metodologia foi a mais eficaz, sendo que o uso isolado da informação molecular (o segundo método) foi menos eficiente que a seleção fenotípica, na maioria das situações.

Edwards \& Page (1994) também utilizaram simulação em computador para avaliar a seleção assistida por marcadores em relação à seleção recorrente fenotípica. Para tanto, um genoma foi simulado com um número variável de QTL's, no qual grupos de ligação eram formados por um QTL por grupo e um ou dois locos marcadores, com frequência de 
recombinação variável. A seleção assistida por marcadores era feita apenas com base no genótipo quanto às marcas. A resposta a ela foi maior quando o número de QTL's era menor, e com uma menor distância entre estes e as marcas. O uso de dois locos marcadores, ao invés de um, também mostrou superioridade no ganho com a seleção e na manutenção do desequilíbrio de ligação. Assumindo que a seleção assistida por marcadores pudesse ser feita também em casa de vegetação, o que permitiria completar 2 ciclos de seleção por ano, os autores observaram uma alta eficiência em relação à seleção recorrente fenotípica, considerando o ganho por ano, especialmente nos primeiros anos, e quando a herdabilidade da característica foi inferior a 0,40.

Gimelfarb \& Lande (1994a) simularam em computador um genoma de 10 Morgans, com 25 QTL's distribuídos ao acaso, de efeitos diferenciados e de natureza aditiva, e avaliaram a seleção assistida por marcadores utilizando o índice de seleção de Lande \& Thompson (1990). Para tanto, consideraram 11 marcas por cromossomo, sendo que 6 delas eram selecionadas em cada ciclo e utilizadas no índice, uma população de 500 indivíduos de cada sexo, herdabilidade inicial igual a 0,1 e $25 \%$ como proporção de indivíduos selecionados. Variações nesses valores foram feitas considerando um parâmetro de cada vez. A população base foi constituída pelo cruzamento de duas linhagens endogâmicas, e as sucessivas gerações foram formadas pela recombinação aleatória dos indivíduos selecionados no ciclo anterior. Para estimar o escore molecular em (2.9), os autores valeram-se da construção de um modelo de regressão múltipla em dois estágios. Uma seleção preliminar de marcas foi feita separadamente por grupo de ligação utilizando o método "forward" (Draper \& Smith, 1991), e em seguida um modelo completo com todas essas marcas selecionadas foi ajustado, mantendo-se porém apenas um número fixo ( 6 na situação padrão) daquelas com maior contribuição ao coeficiente de determinação. 
De uma maneira geral, os resultados encontrados por Gimelfarb \& Lande (1994a) evidenciaram a eficiência da seleção assistida por marcadores. Frequentemente, encontraram valores de ganho maiores que o dobro daquele alcançado com a seleção fenotípica. Um fator que contribuiu para a efetividade do método por vários ciclos seletivos foi o fato de as marcas serem reavaliadas, ou seja, os coeficientes de regressão e do índice de seleção serem reestimados em cada ciclo. $O$ tamanho da população foi tido pelos autores como o principal fator afetando a potencialidade da técnica. Por exemplo, no primeiro ciclo seletivo, ao aumentá-lo de 100 para 3000 indivíduos de cada sexo, a eficiência saltou de 1,18 ou 1,44 para 2,77 ou 2,87 , conforme a fase de ligação entre QTL's tenha sido de total repulsão ou total associação.

Conforme previsto pela segunda expressão em (2.19), os autores reportaram um aumento de eficiência com a diminuição da herdabilidade, tendo se elevado de 1,40 a 2,34, à medida que este parâmetro genético diminuiu de 0,40 para 0,10 .

Uma avaliação da seleção assistida por marcadores em presença de fatores não-aditivos foi feita por Gimelfarb \& Lande (1994b). Tais fatores compreenderam: interação alélica dominante, epistasia e interação de genótipos por ambientes, todos com magnitude variável. O genoma, o conjunto básico de valores de parâmetros sob estudo, a construção da população base, e o método de seleção de marcas foram idênticos àqueles considerados por Gimelfarb \& Lande (1994a). Na maioria das situações onde fatores não-aditivos estavam presentes, Gimelfarb \& Lande (1994b) verificaram altos valores para a eficiência da seleçāo assistida por marcadores. Entretanto, dentre estes fatores, a interação de genótipos por ambientes reduziu sensivelmente a efetividade do método.

Ferreira (1995) avaliou a eficiência da seleção assistida por marcadores em relação à seleção recorrente fenotípica, simulando genomas com 10 ou 100 QTL's, na presença ou ausência de dominância completa. Para 
tanto, considerou dois sistemas de seleção, um baseado apenas na informação molecular, e outro adaptando o índice de seleção de Lande \& Thompson (1990), de maneira semelhante àquela feita por Zhang \& Smith (1992). De uma maneira geral, o uso do índice de seleção mostrou-se como o método mais eficiente, ao se tomar por referência o ganho por ciclo, especialmente com valores de herdabilidade iguais ou menores que 0,25. Estabelecendo pressuposições semelhantes àquelas feitas por Edwards \& Page (1994), de que a seleção baseada apenas nos marcadores poderia completar 2 ciclos seletivos em 1 ano, Ferreira (1995) observou que, dessa forma, o método seria de grande eficiência, tendo o ganho por ano como referência.

Euclydes (1996) apresentou um programa de simulação computacional, denominado de "Genesys" (de "Genetic System"), voltado para a avaliação de esquemas de seleção utilizando marcadores moleculares e sua comparação com métodos clássicos, baseados apenas na informação fenotípica. Embora concebido com particularidades próprias do melhoramento animal, seu uso pode ser estendido, até certo ponto, ao melhoramento vegetal. O sistema permite a simulação da estrutura física de um genoma, variando seu tamanho, número e tamanho dos cromossomos, número e posição de QTL's e marcadores moleculares. Também podem ser especificados ou simulados: frequências alélicas iniciais da população a ser melhorada, número de alelos por loco, efeito dos alelos dos QTL's (conforme as distribuições normal, Poisson ou binomial), efeitos de dominância (variando a distribuição, a natureza e o grau), epistasia (compreendendo interações de forma sequencial ou paralela), e efeitos fixos de ambiente. É ainda possível a simulação de diversas características a um só tempo, com niveis de correlação genética variável, diferentes números de machos e fêmeas, e ainda relações de parentesco entre indivíduos. Trata-se, portanto, de um sistema bastante amplo para a avaliação da seleção assistida por marcadores, sob condições diversas. 
O autor apresentou exemplos de populações-base simuladas, com 200 machos e 200 fêmeas, e um genoma fictício de comprimento total de $3000 \mathrm{cM}$, e 15 cromossomos de tamanhos aleatórios. A cada geração, 500 descendentes eram obtidos pelo cruzamento aleatório de 10 machos com 100 fêmeas. Variou-se o número de marcadores (50 a 200), a herdabilidade $(0,10$ e 0,50$)$ e o número de características (1 e 2), controladas por 500 locos quantitativos. Quando este número era igual a 2, variou-se também a natureza da correlação genética. A ocorrência de efeitos fixos de ambiente também foi simulada.

A partir da simulação dessas populações, foram comparados os seguintes métodos de seleção: a) baseada tão-somente em marcadores moleculares (abreviada pelo autor como MAS); b) individual, baseada no fenótipo (IND); c) individual, associada ao uso de marcadores (IND+MAS); d) índice de seleção, para o caso de 2 características quantitativas (IDX); e) índice de seleção reunindo informação fenotípica e molecular (IDX+MAS); f) melhor predição linear não-viesada, utilizando informações de parentesco na seleção de reprodutores (BLUP), e g) combinação de BLUP com MAS, na qual a informação de parentesco era inferida a partir de dados moleculares. Para a comparação entre esses métodos, foram simuladas 100 gerações, repetidas 5 vezes.

Os resultados obtidos por Euclydes (1996) mostraram que o método MAS, de um modo geral, foi o de pior desempenho, quanto aos ganhos realizados e à fixação de alelos desfavoráveis, independente do número de marcadores. Este método foi no entanto superior aos demais, sob baixa herdabilidade e correlação genética negativa, durante as 10 primeiras gerações. $\mathrm{Na}$ presença de efeitos fixos de ambiente, os métodos BLUP e BLUP+MAS foram superiores em todas as gerações. Os demais métodos utilizando informação molecular tiveram desempenho semelhante, por 10 a 15 gerações. Posteriormente, houve perda de eficiência, atribuída à queda do grau de 
desequilíbrio de ligação. De uma forma geral, foi sugerido que o uso de marcadores moleculares seria válido, nas primeiras gerações, e sob baixa herdabilidade.

A grande maioria dos trabalhos envolvendo simulação de seleção assistida por marcadores utilizaram seleção massal e populações-base compostas a partir de duas linhagens endogâmicas (Gimelfarb \& Lande, 1994a,b; Edwards \& Page, 1994; Ferreira, 1995). Seria interessante avaliar a técnica levando em conta o uso de progênies como unidades de seleção, e populações-base de tamanho efetivo maior do que 1 (que é seu valor quando se utiliza apenas duas linhagens), condições essas mais frequentes no melhoramento vegetal, ao menos em plantas autógamas (Tabela 5).

Não existem na literatura muitos resultados sobre a utilização da seleção assistida por marcadores no melhoramento de características quantitativas em uma situação real. Stromberg et al. (1994) avaliaram o uso de marcadores para o melhoramento de um híbrido comercial de milho, em relação ao uso exclusivo da informação fenotípica. Para tanto, plantas da população conhecida como $\mathrm{BS} 11(\mathrm{FR}) \mathrm{C}_{7}$ foram cruzadas com uma de suas linhagens genitoras. Obtidas plantas $F_{2}$, estas foram classificadas com relação a locos marcadores do tipo RFLP. Em seguida, cruzamentos-teste foram feitos entre estas e a outra linhagem, os quais permitiram a deteç̧ão de QTL's associados a produtividade. Autofecundações foram praticadas, e novos cruzamentos-teste foram realizados utilizando 220 famílias $S_{4}$, obtidas de plantas $F_{2}$. A seleção assistida por marcadores foi praticada através de um índice compreendendo a informação de 8 locos de RFLP, tendo por critérios de ponderação o nivel de significância da detecção QTL-marcador, e o valor fenotípico médio das famílias com um certo genótipo em um dado loco. Nos mesmos cruzamentos-teste, foi também praticada a seleção convencional. As duas populações melhoradas foram avaliadas cada qual em 2 localidades. Em Illinois a seleção assistida por marcadores mostrou-se $3 \%$ superior, enquanto 
que em lowa foi 3,5\% pior. Considerando o resultado conjunto, o desempenho de ambos os métodos de seleção foi semelhante.

Ainda no mesmo estudo, Stromberg et al. (1994) verificaram que o uso de marcadores moleculares também não foi eficiente na seleção dentro de famílias de cruzamento-teste. De uma maneira geral, a correlação entre os valores do índice de seleção e a produtividade de grãos nas famílias foi muito baixa, igual a 0,07 . Nenhum dos sistemas de seleção (fenotípica ou assistida por marcadores) produziu cruzamentos de desempenho superior ao híbrido original.

Freyre \& Douches (1994) ajustaram modelos de regressão múltipla para a seleção de clones de batata, objetivando o melhoramento de populações diplóides, com relação ao peso específico de tubérculos. Procuraram assim basear a seleção em locos marcadores que apresentassem menor interação de genótipos por ambientes, e assim diminuir seu impacto. Foram obtidos 110 genótipos a partir do cruzamento entre dois clones, os quais foram avaliados em 3 locais. Utilizou-se um marcador morfológico, 10 locos isoenzimáticos, 44 do tipo RFLP, e 63 de RAPD. Contrastes entre classes genotípicas em cada loco foram estimados para detectar QTL's, bem como para quantificar interações epistáticas e de genótipos por ambientes. A partir dos locos que apresentaram associações significativas com QTL's, modelos de regressão múltipla (multilocos) foram ajustados em cada local e conjuntamente. Quando isso foi feito em ambientes isoladamente, sensiveis reduçōes no coeficiente de determinação ocorreram. Ajustes superiores foram obtidos utilizando médias dos 3 locais. Freyre \& Douches (1994) concluíram assim que o uso de marcadores apresenta potencial para a seleção precoce nas primeiras gerações clonais, reduzindo o impacto da interação de genótipos por ambientes.

Edwards \& Johnson (1995) reportaram a utilização de marcadores moleculares para o melhoramento de características quantitativas em milho doce. Estes autores trabalharam com populações oriundas do 
cruzamento entre duas linhagens elite, do qual, em cada população, famílias $F_{4}$ foram obtidas pelo método de descendente de uma única semente. Membros dessas familias foram classificados com relação a 61 locos de RFLP distribuidos ao longo do genoma, e o seu desempenho foi avaliado no tocante a várias características, quando em cruzamentos com testadores de interesse para a produção de híbridos. A partir dessa avaliação, contrastes foram feitos objetivando a detecção de QTL's para cada loco marcador. Os autores desenvolveram um índice de seleção para o melhoramento de características de produção e de qualidade, como aceitabilidade e adequação para o processamento. Este índice foi utilizado na seleção baseada somente nos marcadores, e também na seleção fenotípica, em uma das populações, para comparação futura. No primeiro método, as linhagens superiores eram recombinadas, e na geração seguinte a seleção era praticada novamente. A partir de então, cada geração correspondeu a um ciclo seletivo, pois os indivíduos eram classificados quanto aos locos marcadores antes do florescimento, selecionados e depois recombinados. Ao todo, no mesmo período de tempo, foram praticados 4 ciclos de seleção assistida por marcadores, e 1 ciclo de seleção fenotípica, de cujas populações resultantes foram obtidas linhagens e cruzamentos-teste, que permitiram avaliar e comparar os métodos.

Os resultados mostraram ganhos significativos, para a maioria das características, em uma das populações que sofreu seleção assistida por marcadores. Uma outra população apresentou um ganho positivo para características de produção, equivalentemente a quase duas vezes e meia o ganho observado na população onde se utilizou seleção fenotípica. Para as características qualitativas, no entanto, o ganho foi negativo, de desempenho bastante inferior. Os autores justificaram esse resultado pela alta herdabilidade dessas características, o que sabidamente prejudica a eficiência da seleção assistida por marcadores. 
Finalizando, deve-se salientar que, embora a ênfase maior no presente item tenha sido dada à seleção assistida por marcadores referente a características quantitativas, a metodologia tem sido aplicada (em maior escala) para lidar com características de herança simples ou monogênica (por exemplo, Weeden \& Providenti, 1988; Feuerstein et al., 1990; Koebner \& Martin, 1990; Messeguer et al., 1991; Miklas et al., 1996). 


\section{METODOLOGIA}

O presente estudo compreendeu duas etapas distintas, a saber:

1) A obtenção de um estimador da proporção da variância genética explicada por marcadores moleculares, e sua avaliação sob condições variadas e na seleção assistida por marcadores;

2) A avaliação da seleção assistida por marcadores (SAM) enquanto método de melhoramento em espécies autógamas, mediante simulação computacional, e sob diferentes pressuposições quanto a valores de parâmetros genéticos, esquemas de seleção e condições ambientais.

Cada uma dessas etapas será detalhada a seguir.

\subsection{Estimação de $p$ e de $b_{M}$}

Um estimador pontual da proporção da variância genética explicada por marcadores moleculares ( $p$ ) foi obtido, o qual pudesse, por sua vez, ser utilizado na estimação do coeficiente associado ao escore molecular $\left(b_{M}\right)$, no índice de seleção de Lande \& Thompson (1990). Tais estimadores foram importantes, posteriormente, para implementar a avaliação da seleção 
assistida por marcadores em espécies autógamas, mediante simulação em computador. O método de estimação utilizado foi o dos momentos, sendo que os estimadores $\hat{\mathrm{p}}$ e $\hat{b}_{\mathrm{M}}$ foram expressos como funções de quadrados médios. Estes, por sua vez, foram referentes à partição da variação entre grupos genéticos (por exemplo, progênies) em duas fontes, sendo uma relacionada a um modelo de regressão múltipla, associado a marcadores moleculares, e outra referente aos desvios de regressão, conforme apresentado na Tabela 11.

Pressupôs-se distribuição normal aos valores fenotípicos, e assim admitiu-se que as formas quadráticas tivessem distribuições associadas à qui-quadrado, e que fossem independentes entre si. Dessa forma, pôde-se utilizar o teorema da transformação de variáveis aleatórias multidimensionais (Mood et al., 1974), para obter a distribuição de amostragem desses estimadores. No tocante a $\hat{\mathrm{p}}$, esta distribuição também foi gerada mediante simulação de Monte Carlo, sendo que o algoritmo de Best \& Roberts (1975) foi utilizado para calcular as inversas de qui-quadrado necessárias.

Em virtude da inviabilidade de expressar a esperança e a variância de $\hat{\mathrm{p}}$ explicitamente, foram derivadas expressões aproximadas referentes a esses parâmetros, utilizando a expansão em série de Taylor da razão entre 2 variáveis aleatórias, conforme apresentado por Mood et al. (1974). Isso possibilitou a elaboração de aproximações normais para a distribuição de amostragem de $\hat{\mathrm{p}}$, as quais foram comparadas com a distribuição obtida por simulação computacional de Monte Carlo.

As estatísticas $\hat{p}$ e o coeficiente de determinação $\left(R^{2}\right)$ foram comparadas enquanto estimadores da proporção da variância genética explicada por marcadores moleculares. Os critérios de comparação foram principalmente os niveis relativos de tendenciosidade e de precisão. Para tanto, foram consideradas diferentes situações, variando a herdabilidade $(0,2$ e 0,8$)$, o 
valor do parâmetro $p(0,1$ e 0,9$)$, e o número de grupos genéticos avaliados (10 e 400).

A distribuição de amostragem de $\hat{b}_{M}$ foi obtida analiticamente, através do teorema da transformação de variáveis aleatórias multidimensionais, possibilitando o estudo desse estimador, utilizando dois valores para o parâmetro $b_{M}(1$ e 40).

\subsection{Avaliação da SAM em Espécies Autógamas}

A utilização da seleção assistida por marcadores (SAM) no melhoramento de espécies autógamas foi avaliada mediante simulação computacional, conforme descrito nos itens a seguir.

\subsubsection{Simulação do Genoma e da Gametogênese}

A simulação em computador empregada neste trabalho baseou-se em uma espécie vegetal diplóide, apresentando meiose regular, sistema reprodutivo de autofecundação completa, com 10 cromossomos e um mapa genético de comprimento total igual a 10 Morgans. Trata-se de um genoma que pode ser tido como típico em plantas (King, 1974). Cada cromossomo teve um comprimento de 1 Morgan, ou seja, com a ocorrência média de um ponto de permuta genética.

Neste genoma foram distribuidos 50 QTL's aleatoriamente (Figura 1), referentes a uma característica quantitativa fictícia. Seus efeitos, 
também representados na Figura 1, foram diferenciados e de tal maneira que os de menor magnitude eram mais frequentes do que os de maior valor. Para tanto, estes efeitos foram gerados aleatoriamente a partir de uma função densidade de probabilidade $\mathrm{f}(\mathrm{a})$ exponencial, com parâmetro igual a 1 :

$$
f(a)=e^{-a}
$$

em que "a" corresponde à metade da diferença entre os valores dos homozigotos para cada loco, e a constante "e" é o número neperiano. A aparência dessa função, bem como a distribuição de frequência absoluta dos efeitos gerados para os 50 QTL's podem ser visualizados na Figura 2. De acordo com este sistema simulado, os 16 locos de maior efeito seriam responsáveis por $86,1 \%$ da variância genética aditiva em uma população hipotética em equilíbrio de ligação, onde os alelos de todos os 50 locos estivessem segregando com frequência igual a 0,5.

A interação alélica existente foi considerada como sendo a de ausência de dominância na maioria dos casos, mas a ocorrência de dominância positiva completa também foi simulada.

Neste mesmo genoma, 13 locos marcadores foram distribuídos sistematicamente em cada cromossomo, a cada 0,083 Morgan (Figura 1). A sua disposição sistemática (ao invés de, por exemplo, aleatória) justifica-se pelo fato de, em uma situação real, os marcadores serem em geral escolhidos dentre os disponíveis nos mapas de ligação, cobrindo todo o genoma da maneira a mais homogênea possível. Em algumas situações, foi utilizado um número menor de locos marcadores (3 por cromossomo), e em outras um número maior (18 por cromossomo), para estudar o efeito do nível de saturação do mapa molecular.

Foram dispostos centrômeros aleatoriamente no terço mediano dos cromossomos, devido ao fato de estes serem predominantemente 
metacêntricos e submetacêntricos em algumas das mais importantes espécies autógamas cultivadas (Stebbins, 1971; pg. 87).

A simulação da gametogênese foi feita mediante um modelo de permuta genética baseado numa função de mapeamento que considera a presença de interferência entre pontos de permuta, e entre esses e o centrômero. A função de mapeamento utilizada foi aquela apresentada por Owen (1949):

$$
f(u)=4 u e^{-2 u}, \quad u \geq 0
$$

em que u representa uma escala de medida de mapeamento genético. Admitiuse que o valor 0 representa a posição do centrômero ou do último ponto de permuta. A posição do quiasma seguinte era determinada pela distribuição (3.2), que corresponde à de uma variável qui-quadrado com 4 graus de liberdade, dividida por 4. Este modelo implica que o valor de interferência seja igual a 0,5. Dessa forma, foi empregada a teoria de braços cromossômicos longos (Owen, 1949), não tendo se levado em conta o fato de estes serem finitos. Conforme Bailey (1961, pg.189) observou, este enfoque pode ser razoável apesar dessa limitação, dado que a formação de quiasmas possa ser pensada como um processo serial com início no centrômero.

Através da geração de um valor aleatório $u$, conforme (3.2), a posição $x$ da permuta correspondente, expressa em Morgans, pôde ser obtida através de (Owen, 1949):

$$
x(u)=u-\frac{1}{4}+\frac{1}{4} e^{-4 u}
$$

O modelo de recombinação utilizado pode corresponder a uma função de mapeamento genético biologicamente mais realista, uma vez que leva em conta a ocorrência de interferência. Ele foi portanto escolhido, em virtude de o desequilíbrio de ligação (bem como a eficiência da seleção assistida 
por marcadores) ser consequência direta da ocorrência de recombinação. A Figura 3 ilustra a correspondência entre as escalas u e $x$.

\subsubsection{Esquema de Seleção Recorrente Utilizado}

Linhagens totalmente endogâmicas foram simuladas para que, em cruzamento, compusessem uma população base, a partir da qual ciclos seletivos tivessem início. No esquema de seleção recorrente utilizado, alguns parâmetros assumiram valores distintos em diferentes simulações, de maneira a possibilitar o estudo da eficiência da seleção assistida por marcadores em condições variadas. Estes valores estão apresentados na Tabela 12.

O número de linhagens para iniciar o programa de melhoramento simulado foi igual a 5 na maioria das situações, embora também tenha se estudado o efeito de se utilizar 20 linhagens para a composição da população-base. Tomando por base o genoma especificado no item 3.2.1, as linhagens foram tais que apenas $20 \%$ dos 50 locos controladores da característica (totalizando 10) apresentavam alelos favoráveis fixados, ou seja, representando uma cultura em estágio relativamente inicial quanto ao melhoramento genético.

A população base, ou de ciclo $0\left(C_{0}\right)$, foi formada como ilustrado a seguir, para os casos de serem 5 as linhagens iniciais (grande maioria das situações). Cada uma das linhagens foi cruzada com outras duas mediante um esquema de dialelo circulante, totalizando 5 cruzamentos (Figura 4), sendo que estes foram tais que um certo nível de dissimilaridade genética foi mantido constante entre cada par de genitores. Com isso, objetivou-se simular uma situação real, onde em geral o melhorista procura combinar materiais não 
relacionados, com base em informações de genealogia elou quanto à sua origem geográfica (McNeal et al., 1978; Kenworthy \& Brim, 1979; Brim \& Burton, 1979; Garland \& Fehr, 1981; Prohasca \& Fehr, 1981; Payne et al., 1986). Para tanto, a medida de dissimilaridade genética (D) usada foi:

$$
D=\frac{b+c}{a+b+c+d}
$$

em que "b" é o número de locos com alelos favoráveis fixados no primeiro genitor, mas não no segundo; "c" é como b, trocando a ordem dos genitores; " $a$ " é o número de locos com alelos favoráveis fixados em ambos os genitores; e "d" é o número de locos com alelos desfavoráveis fixados nas duas linhagens. A dissimilaridade genética foi fixada em 0,40 em todos os cruzamentos, o que correspondeu à ocorrência de 20 QTL's segregando simultaneamente nos cruzamentos da população do ciclo 0 .

Em cada cruzamento, os indivíduos $F_{1}$ foram autofecundados por um número de vezes que foi igual a 1 ou 3 , obtendo gerações $\mathrm{F}_{2}$ ou $\mathrm{F}_{4}$, respectivamente. Para uniformidade de notação ao longo dos ciclos seletivos, gerações $F_{2}, F_{3}$ e $F_{5}$ foram designadas por $S_{0}, S_{1}$ e $S_{3}$, respectivamente, na Figura 4. A população de referência, na qual a média de valores genotípicos em um dado ciclo seletivo era calculada, foi aquela de indivíduos $\mathrm{S}_{0}$.

O avanço das gerações de autofecundação foi feito pelo método de descendente de uma única semente, e conduzido separadamente em cada cruzamento ou subpopulação. Nestes, o número de indivíduos obtidos foi predominantemente igual a 400 , embora também tenham sido empregadas duas variações: 160 ou 300, conforme apresentado na Tabela 12. Posteriormente, foram obtidas progênies pela autofecundação desses indivíduos, conforme dois sistemas distintos. O primeiro, doravante denominado "precoce", consistiu da geração de progênies $S_{1}$ de plantas $S_{0}$, com 10 
indivíduos em cada uma de 2 repetições. Este sistema reflete uma situação real, na qual a disponibilidade de sementes é geralmente reduzida em gerações precoces de programas de melhoramento de plantas autógamas, demandando o uso de poucas repetições e de parcelas pequenas, como aquelas em cova, utilizadas na cultura da soja (Garland \& Fehr, 1981).

Pelo segundo sistema, denominado "avançado", progênies $S_{3}$ foram obtidas de indivíduos $S_{2}$, com 30 plantas em cada uma de 2 repetições, o que representa o fato de que, com o avanço das gerações de autofecundação, a disponibilidade de sementes aumenta.

Obtidas as progênies, estas foram avaliadas simulando um delineamento inteiramente casualizado (Steel \& Torrie, 1980) com 2 repetições e parcelas de 10 ou 30 plantas, conforme o sistema ter sido precoce ou avançado. Por uma facilidade de programação, esta avaliação foi feita separadamente em cada subpopulação, ainda que em uma situação real uma análise conjunta envolvendo toda a população, incluindo fontes de variação entre e dentro de cruzamentos, poderia ser realizada, a qual teria a vantagem de fornecer uma estimativa do erro experimental mais precisa. O modelo estatístico relativo a essa avaliação foi:

$$
y_{i j l}=\mu+t_{i}+e_{(i) j}+r_{(i j) !}+w_{(i) !}
$$

em que:

$y_{i j k}$ : fenótipo da planta I dentro da progênie i na repetição j;

$\mu$ : efeito de uma constante comum a todas as plantas;

$\mathrm{t}_{\mathrm{i}}$ : efeito genético relativo à progênie $\mathrm{i}$;

$\mathrm{e}_{(i) \mathrm{j})}$ : efeito ambiental correspondente ao erro experimental associado à progênie i na repetição $\mathrm{j}$, com distribuição normal $\mathrm{N}\left(0, \sigma_{\mathrm{e}}^{2}\right)$; 
$r_{(i j) !}$ : efeito genético da planta 1 dentro da progênie $i$, na repetição j;

$\mathrm{w}_{(\mathrm{ij}) \text { ): }}$ efeito ambiental associado à planta I dentro da progênie $\mathrm{i}$, na repetição j, com distribuição normal $\mathrm{N}\left(0, \sigma_{w}^{2}\right)$.

A simulação dos efeitos $e_{(0) j}$ e $w_{(i j) !}$ do modelo (3.5) foi feita como segue. Primeiramente, foram estipulados diferentes valores de herdabilidade $\left(h^{2}\right)$ para a característica, objetivando estudar seu efeito na seleção assistida por marcadores (Tabela 12). Embora a unidade de seleção empregada tivesse sempre sido progênies, a herdabilidade de referência foi aquela entre plantas $S_{0}$, uma vez que, conforme o sistema ter sido precoce ou avançado, o tamanho da parcela e o nivel de endogamia variaram, os quais afetam a herdabilidade ao nível de média de progênies. Representando por $p_{i} 0$ fenótipo da planta i $S_{0}$, tem-se que:

$$
p_{i}=g_{i}+u_{i}
$$

em que $g_{i}$ é o efeito genético associado ao indivíduo $i$, e $u_{i}$ é seu efeito ambiental. A determinação de $g_{i}$ foi feita somando as contribuições associadas a cada um dos QTL's, conforme o conhecimento de seus efeitos (Figura 1) e do genótipo em cada loco. Esse procedimento foi feito sempre que necessário, em qualquer geração ou ciclo seletivo. $O$ termo gi poderia ou não conter efeitos de dominância, conforme o modelo genético adotado. A partir dessa determinação, a variância genética total em cada um dos 5 cruzamentos iniciais foi computada pela geração aleatória de 20.000 indivíduos $S_{0}$. Os valores calculados das variâncias genéticas estão apresentados na Tabela 13 , considerando ou não a presença de dominância. Quando 20 progênies foram utilizadas para compor a população-base, um procedimento idêntico foi empregado.

A variância ambiental $\sigma^{2}$, relativa ao termo $u_{i}$, foi computada usando a relação: 


$$
\sigma^{2}=\frac{\bar{\sigma}_{G}^{2}}{h^{2}}-\bar{\sigma}_{G}^{2}
$$

na qual $\bar{\sigma}_{G}^{2}$ corresponde à variância genética média dos cruzamentos. $O$ termo $\mathrm{u}_{\mathrm{i}}$, por sua vez, foi decomposto nos componentes ambientais entre e dentro de parcela:

$$
u_{i}=e_{i}+w_{i}
$$

que são equivalentes aos do modelo (3.5), com apenas uma simplificação de notação. A pressuposição envolvida é a de que tais componentes afetam o fenótipo das plantas independentemente da geração e do nível de endogamia em que se encontram. A simulação de seus valores foi feita independentemente para cada um, o que implicou que:

$$
\sigma^{2}=\sigma_{e}^{2}+\sigma_{w}^{2}
$$

As magnitudes relativas $\sigma_{e}^{2}$ e $\sigma_{w}^{2}$ foram atribuídas admitindo um solo de heterogeneidade média, o que pôde ser feito especificando um valor de 0,5 ao coeficiente b de heterogeneidade de solo (Smith, 1938). O procedimento pelo qual isso foi feito está descrito no item 3.2.3.

Avaliadas as progênies, as superiores foram selecionadas tendo por critério suas médias fenotípicas, ou utilizando seleção assistida por marcadores, a qual será detalhada no item 3.2.4. Foram simulados programas de melhoramento com diferentes valores quanto à proporção de progênies selecionadas, apresentados na Tabela 12. Não foi feita seleção de cruzamentos ou subpopulações em momento algum, sendo que um número constante de progênies selecionadas foi mantido em cada cruzamento. Em cada progênie selecionada, simulou-se a tomada aleatória de um número fixo de plantas sorteadas. Este número variou de 1 (quando 0 número de progênies selecionadas era maior que 1 ), a 5 , quando apenas uma progênie era selecionada em cada subpopulação. Estas plantas eram autofecundadas, e 
seus descendentes eram cruzados com materiais selecionados em outros cruzamentos (etapa de recombinação), formando a população do ciclo seguinte (Figura 4). Todo esse processo foi repetido durante 6 ciclos de seleçāo recorrente. A título de ilustração, considere-se a situação na qual 20 progênies eram selecionadas por cruzamento. Um descendente era tomado ao acaso em cada uma delas, e cruzado com 20 outros, obtidos de progênies selecionadas em outro cruzamento. Assim, eram gerados 400 indivíduos, cujos descendentes de uma única semente compunham por sua vez a população $S_{0}$ do ciclo seguinte.

A recombinação, ao invés de aleatória, foi praticada de maneira a minimizar o grau de parentesco entre os indivíduos em cruzamento, conforme representado na Figura 4. Não foram nunca intercruzados materiais com linhagens genitoras em comum. Este procedimento sistemático de recombinação foi utilizado em todos os ciclos seletivos, e tem por consequência um aumento no tamanho efetivo da população, e consequentemente uma maior manutenção da variabilidade e dos ganhos com a seleção a médio ou longo prazo.

A simulação de 6 ciclos de seleção recorrente, fenotípica e assistida por marcadores, foi repetida 10 vezes para cada uma, em cada conjunto de valores especificados (Tabela 12) para parâmetros de interesse. Uma vez estabelecidos os programas de computador, em sua forma definitiva, foram necessárias cerca de 250 horas para a geração dos resultados, em processador Pentium, utilizando $150 \mathrm{MH}$. A linguagem de programação empregada foi a Pascal, em sua versão 5.5 para sistema operacional "DOS". 


\subsubsection{Simulação da Variância Ambiental Entre e Dentro de Parcelas}

A variância ambiental $\sigma^{2}$ entre plantas cultivadas em um solo pode ser decomposta em um componente associado à variação dentro de parcelas $\left(\sigma_{\mathrm{w}}^{2}\right)$ e outro associado àquela existente entre parcelas $\left(\sigma_{\mathrm{e}}^{2}\right)$. Para se determinar que fração de $\sigma^{2}$ conferir a um ou a outro componente em uma simulação de um experimento de campo, pode-se utilizar um enfoque baseado no coeficiente de heterogeneidade de solo de Smith (1938). Este coeficiente, simbolizado por $b$, pode variar entre 0 e 1 , e estabelece uma relação entre $a$ variância entre médias de parcelas com $x$ plantas $\left(V_{x}\right)$ com a variância total entre plantas $\left(V_{1}\right)$. Essa relação é dada por (Smith, 1938):

$$
V_{x}=\frac{V_{1}}{x^{b}}
$$

O valor de b é peculiar do solo e da característica em questão. $O$ autor traçou algumas considerações admitindo que o número total de plantas no solo tendesse ao infinito. Denotando por $\left(\mathrm{V}_{\mathrm{r}}\right)_{\mathrm{s}}$ a variância entre médias de $\mathrm{s}$ grupos com r plantas (grupos esses podendo ser parcelas experimentais), e admitindo a validade da relação (3.10) com s tendendo ao infinito, tem-se:

$$
\left(V_{x}\right)_{\infty}=\frac{\left(V_{1}\right)_{\infty}}{x^{b}}
$$

Smith (1938) observou que, se o solo for dividido em $\lambda$ blocos com m parcelas de $x$ plantas, então a decomposição da variação entre e dentro de blocos é como apresentado na Tabela 14. O autor demonstrou que:

$$
\lim _{\lambda \rightarrow \infty}\left(V_{x}\right)_{m}=\frac{m\left(1-m^{-b}\right)}{m-1}\left(V_{x}\right)_{\infty}
$$

O enfoque proposto aqui consiste em fazer $\mathrm{x}$ igual a 1 , e $\mathrm{m}$ igual ao tamanho de parcela desejado. Dessa forma, os "blocos" 
corresponderão na realidade a parcelas com m plantas. Assim, em um solo com um número $\lambda$ consideravelmente grande de parcelas, tem-se que os termos $\left(V_{x}\right)_{\lambda m},\left(V_{x m}\right)_{\lambda}$ e $\left(V_{x}\right)_{m}$, da Tabela 14, podem ser rescritos como:

$$
\begin{aligned}
& \lim _{\lambda \rightarrow \infty}\left(V_{1}\right)_{\lambda m}=\left(V_{1}\right)_{\infty} \\
& \lim _{\lambda \rightarrow \infty}\left(V_{m}\right)_{\lambda}=\left(V_{m}\right)_{\infty} \\
& \lim _{\lambda \rightarrow \infty}\left(V_{x}\right)_{m}=\frac{m\left(1-m^{-b}\right)}{m-1}\left(V_{1}\right)_{\infty}
\end{aligned}
$$

os quais estão apresentados na Tabela 15. A última relação em (3.13) foi obtida a partir da expressão (3.12). O termo $\left(V_{1}\right)_{\infty}$ nada mais é que a variância ambiental total entre plantas em um solo consideravelmente grande. Ou seja, é equivalente ao parâmetro $\sigma^{2}$. Estabelecido um valor para este em uma simulação, a variância entre médias de parcelas com $m$ plantas, $\left(V_{m}\right)_{\infty}$ é obtido por:

$$
\left(V_{m}\right)_{\infty}=\frac{\left(V_{1}\right)_{\infty}}{m^{b}}
$$

conforme expressão (3.11). Finalmente, a variância ambiental entre plantas dentro de parcelas, $\left(V_{1}\right)_{m}$, é obtido através da última relação em (3.13).

A título de ilustração, se for atribuído ao parâmetro $h^{2}$ um valor de 0,025 , e considerada uma magnitude para a variância genética entre plantas igual a 10,4 unidades ao quadrado, tem-se que $\sigma^{2}$ pode ser obtida através de (3.7), ou seja:

$$
\sigma^{2}=\left(V_{1}\right)_{\infty}=\frac{10,4}{0,025}-10,4=405,62
$$


Admitindo um solo com coeficiente de heterogeneidade $b$ igual a 0,5 , então a variância entre médias de parcelas com 10 plantas (conforme o sistema precoce de obtenção de progênies) vale, de acordo com (3.14):

$$
\left(V_{10}\right)_{\infty}=\frac{405,62}{10^{0,5}}=128,27
$$

Portanto, o quadrado médio entre parcelas (QMEP) é, de acordo com a Tabela 15:

$$
\text { QMEP }=10\left(V_{10}\right)_{\infty}=10.128,27=1282,7
$$

E o quadrado médio dentro de parcelas (QMDP) é, conforme a Tabela 15 e a última das expressões em (3.13):

$$
\begin{aligned}
& \text { QMDP }=\left(V_{1}\right)_{\infty}=\frac{10\left(1-10^{-0,5}\right)}{10-1}\left(V_{1}\right)_{\infty}= \\
& =\frac{10\left(1-10^{-0.5}\right)}{10-1} 405,62=308,17
\end{aligned}
$$

Assim, uma vez que (Tabela 15):

$$
\begin{aligned}
& \text { QMEP }=\sigma_{w}^{2}+m \sigma_{e}^{2} \\
& \text { QMDP }=\sigma_{w}^{2}
\end{aligned}
$$

tem-se que:

$$
\begin{aligned}
& \sigma_{w}^{2}=308,17 \\
& \sigma_{e}^{2}=\frac{1282,7-308,17}{10}=97,45
\end{aligned}
$$

tendo-se assim, portanto, feito uma partição da variância ambiental total entre plantas $\sigma^{2}$ em dois componentes, associados à variação entre e dentro de parcelas. Nota-se que, de fato:

$$
\sigma^{2}=\sigma_{w}^{2}+\sigma_{e}^{2}=405,62
$$




\subsubsection{Utilização de Marcadores na Simulação}

Nos cruzamentos ou subpopulações que originaram a população base, manteve-se o mesmo valor de dissimilaridade genética de 0,40 com relação aos locos marcadores apresentados na Figura 1. Ou seja, quando se utilizou 130 marcas (maioria das situações), 52 encontravam-se polimórficas nos cruzamentos iniciais. Evidentemente, esse número poderia aumentar nos ciclos posteriores devido à recombinação. Em cada subpopulação, esses 52 locos eram espaçados de uma distância aproximadamente constante, variando de 0,083 a 0,250 Morgan. A natureza da herança dos marcadores foi considerada codominante, à semelhança do que acontece em geral com locos de RFLP ou SSR. No entanto, levando em conta que o esquema de seleção recorrente aqui considerado (item 3.2.2) utilizou progênies obtidas por autofecundação como unidades de seleção, os resultados obtidos também puderam ser estendidos para o caso de marcadores dominantes, como o AFLP, uma vez que os indivíduos heterozigotos poderiam ser identificados, mediante teste de progênies.

A deteç̧ão de marcas ligadas a QTL's foi feita em cada cruzamento separadamente, uma vez que a fase de ligação entre aqueles poderia variar nas diferentes subpopulações. Em cada ciclo seletivo, o processo de detecção era repetido. Para tanto, as plantas $S_{0}$ ou $S_{2}$ simuladas, cujos descendentes davam origem às progênies, tinham contado o número de cópias de um dos alelos para cada loco marcador, os quais eram utilizados como variáveis independentes na construção de um modelo de regressão múltipla, tomando o desempenho fenotípico médio das progênies como variável dependente. Tal modelo era construído reparametrizando aquele apresentado em (3.5), de maneira que:

$$
\mu+t_{i}=\alpha+\beta_{1} X_{1 i}+\beta_{2} X_{2 i}+\ldots+\beta_{k} X_{k j}+\delta_{i}
$$


em que $\alpha$ é o coeficiente angular do modelo de regressão linear múltipla; $\beta_{m}$ é o coeficiente de regressão associado ao loco marcador $m ; X_{m i}$ é o número de cópias de um dos alelos da marca $m$; e $\delta_{\mathrm{i}}$ é o desvio de regressão da progênie i. Dessa forma, a variação entre progênies foi decomposta em duas fontes de variação: uma associada à regressão e outra aos desvios de regressão, conforme Tabela 11. Essa decomposição permitiu estimar a proporção da variância genética explicada por marcadores moleculares, conforme item 3.1.

Os locos marcadores que compunham o modelo (3.15) em um dado cruzamento eram selecionados pelo método de "backward" (Draper \& Smith, 1991), com um modelo inicial contendo todas as marcas polimórficas. Para tanto, foi utilizado um nível de significância de 0,05 de probabilidade. 0 teste $\mathrm{F}$ correspondente foi construído dividindo-se o quadrado médio parcial dos coeficientes de regressão pelo quadrado médio dos desvios de regressão (Knapp, 1994).

Em cada subpopulação, a herdabilidade no sentido amplo, ao nível de médias de progênies $\left(H^{2}\right)$, foi estimada mediante:

$$
H^{2}=\frac{r \hat{\sigma}_{G}^{2}}{Q M T}
$$

na qual r e QMT são como definidos na Tabela 11 e:

$$
\hat{\sigma}_{\mathrm{G}}^{2}=\frac{\mathrm{QMT}-\mathrm{QME}}{\mathrm{r}}
$$

Em cada cruzamento de cada ciclo seletivo, um índice de seleção foi construído conforme (2.9), no qual se fez $b_{z}$ igual a 1 , e $b_{M}$ como em (2.17), cuidando que a herdabilidade fosse aquela ao nível de médias de progênies, indicada em (3.16), conforme sugerido por Lande (1992) para o melhoramento de plantas autógamas, e $p$ estimada conforme indicado no item 3.1. Este procedimento foi realizado para as diversas variações consideradas na Tabela 12. Dessa forma, nas situações envolvendo dominância, o coeficiente $b_{M}$ 
foi subestimado em relação àquele que maximizaria o ganho com a seleção, uma vez que a variância genética total foi utilizada para obtê-lo, ao invés da variância aditiva.

\subsubsection{Avaliação da Eficiência da SAM}

A avaliação da seleção assistida por marcadores foi feita pela estimação de alguns parâmetros relacionados à sua eficiência. $O$ ganho observado médio (calculado a partir das 10 repetições de cada simulação) utilizando marcadores $\left(G_{M}\right)$ foi comparado com o ganho médio obtido com a seleção fenotípica $\left(G_{s}\right)$, em cada ciclo seletivo, e em igualdade de condições com relação aos valores dos parâmetros especificados na Tabela 12. Essa comparação foi feita testando a hipótese de igualdade entre ambos, pela estatística:

$$
t_{c}=\frac{G_{M}-G_{S}}{\sqrt{\frac{2}{10} s^{2}}}
$$

na qual:

$$
s^{2}=\frac{9}{18}\left[s_{G M}^{2}+s_{G S}^{2}\right]
$$

em que, por sua vez, $s_{G M}^{2}$ é a variância observada entre os $G_{M}$ nas 10 repetições de cada simulação em um dado ciclo seletivo, e $s_{\mathrm{GS}}^{2}$ aquela entre os Gs. Foi calculado também o seguinte índice de eficiência:

$$
E f=\frac{G_{M}}{G_{s}}
$$


o qual pôde ser comparado com aquele esperado segundo (2.18).

A utilização de marcadores moleculares também foi avaliada pelo cálculo da correlação entre os escores moleculares e os valores genotípicos das progênies, em um dado ciclo seletivo. Esta correlação foi comparada com a raiz quadrada das herdabilidades $\mathrm{H}^{2}$ (que nada mais é do que a correlação entre o fenótipo e o genótipo das unidades de seleção), observadas nas populações em que se praticou seleção fenotípica. Assim, se aquela correlação fosse maior que essa raiz quadrada, então era esperado que o uso de marcadores moleculares fosse eficiente na detecção de progênies de maior valor genotípico.

Também foram calculadas proporções de QTL's apresentando fixação, com alelos favoráveis e desfavoráveis, bem como a proporção de locos marcadores tendo um de seus alelos fixados.

Para monitorar o nivel de desequilíbrio de ligação presente em cada ciclo seletivo, o seguinte procedimento foi adotado, quando um mapa molecular de 130 marcas foi utilizado. Em um dado cruzamento de um ciclo seletivo, foi calculado o desequilíbrio de ligação, conforme expressão (2.3), a partir de todos os pares de locos marcadores distanciados de $16,67 \mathrm{cM}$, e que apresentassem polimorfismo, tomando-se o valor médio. Este era comparado com um valor de referência, observado nos cruzamentos do ciclo 0 , correspondentes a gerações $F_{2}$ ou $F_{4}$, conforme o sistema de obtenção de progênies (precoce ou avançado). Quando se utilizou um mapa de 200 marcas, um procedimento semelhante foi empregado, sendo que considerou-se pares de locos distanciados de $10,53 \mathrm{cM}$. Nas situações em que 30 marcas foram utilizadas no total, esta quantificação do desequilibrio de ligação não foi feita, em virtude da dificuldade de se manter um número satisfatório de pares de locos com polimorfismo em todos os ciclos seletivos. 


\section{RESULTADOS E DISCUSSÃO}

\subsection{Obtenção de Estimadores de $p$ e de $b_{M}$}

A seguir será apresentada a obtenção dos estimadores da proporção da variância genética explicada por marcadores moleculares $(p)$ e do coeficiente associado ao escore molecular $\left(b_{M}\right)$, no índice de seleção de Lande \& Thompson (1990).

\subsubsection{Estimação Pontual de $p$}

A estimação por ponto da proporção da variância genética explicada por marcadores moleculares pode ser feita como seque. Sejam t progênies tomadas aleatoriamente em uma população. Estas progênies podem ser, por exemplo, de meios irmãos, ou obtidas pela autofecundação de $t$ indivíduos. Sendo elas avaliadas com relação a uma característica quantitativa, em $r$ repetições, então a observação referente à j-ésima repetição da i-ésima progênie pode ser descrita pelo modelo:

$$
y_{i j}=\mu+g_{i}+e_{i j}
$$


na qual $\mu$ é uma constante comum a todas as observações, $g_{i}$ é o efeito da iésima progênie, e $e_{i j}$ é o termo residual. Admitindo estes dois últimos efeitos como aleatórios, tem-se que a variância (referente à distribuição de amostragem) associada à observação $y_{i j}$ é:

$$
V\left(y_{i j}\right)=\sigma_{G}^{2}+\sigma^{2}
$$

em que $\sigma_{\mathrm{G}}^{2}$ e $\sigma^{2}$ são os componentes de variância associados à variação entre e dentro de progênies, respectivamente. Supondo que a informação relativa ao número de um dos alelos de $\mathrm{k}$ locos marcadores seja conhecida, para cada indivíduo que deu origem a uma progênie, então uma análise de regressão múltipla pode ser realizada, tomando o conjunto dos totais ou das médias das progênies (no tocante à variável quantitativa) como variável dependente. Isto implica em um rearranjo no modelo (4.1) tal que:

$$
\mu+g_{i}=\alpha+\sum_{j=1}^{k} \beta_{j} X_{i j}+\delta_{i}
$$

no qual $\alpha$ é uma constante, $\mathrm{X}_{\mathrm{ij}}$ é o número de um dos alelos do loco marcador $\mathrm{j}$, referente à progênie $\mathrm{i}$, e $\beta_{\mathrm{j}}$ seu coeficiente de regressão parcial correspondente, e $\delta_{i}$ é o efeito genético não-associado aos marcadores (ou seja, relativo aos desvios da regressão), na progênie i. Como definido em (4.3), o modelo de regressão irá se referir aos efeitos médios (na realidade, uma fração destes, devido à ocorrência da recombinação) de alelos de QTL's eventualmente ligados aos marcadores disponíveis. Obviamente, pela incorporação de parâmetros apropriados ao modelo (4.3), por exemplo aos valores de $X_{i j}$ ao quadrado, ou a produtos cruzados entre $X_{i j}$ 's de diferentes locos marcadores $j$, efeitos não-aditivos, como dominância ou epistasia, poderiam também ser detectados. O termo $\sum_{\mathrm{j}=1}^{\mathrm{k}} \beta_{\mathrm{j}} \mathrm{X}_{\mathrm{ij}}$ foi chamado por Lande \& Thompson (1990) de "escore molecular". Denotando-o por $\mathrm{m}_{\mathrm{i}}$, segue-se, a partir de (4.1) e (4.3), que: 


$$
\mathrm{V}\left(\mathrm{y}_{\mathrm{ij}} \mid \mathrm{m}_{\mathrm{i}}\right)=\sigma_{\mathrm{h}}^{2}+\sigma^{2}
$$

em que $\sigma_{h}^{2}$ refere-se à variância genética não-associada aos marcadores moleculares. Quaisquer covariâncias entre duas diferentes repetições j e j' da mesma progênie i são dadas por:

$$
\operatorname{Cov}\left(y_{i j}, y_{i j} \mid m_{i}\right)=\sigma_{h}^{2}
$$

Sem condicionar em $m_{i}$, a variância genética total entre as progênies da população pode ser particionada em dois componentes, associado e nãoassociado a marcadores moleculares:

$$
\sigma_{G}^{2}=\sigma_{M}^{2}+\sigma_{h}^{2}
$$

em que:

$$
\sigma_{M}^{2}=V\left(\sum_{j=1}^{k} \beta X_{i j}\right)
$$

é a variância entre os escores moleculares, ou seja, a porção da variância genética explicada por marcadores. Do ponto de vista do estudo e da manipulação da característica em questão, o ideal é ter $\sigma_{h}^{2}$ próximo a zero, para uma dada $\sigma_{\mathrm{G}}^{2}$. A proporção da variância genética explicada por marcadores moleculares é portanto a razão:

$$
p=\frac{\sigma_{M}^{2}}{\sigma_{M}^{2}+\sigma_{h}^{2}}
$$

Sendo as progênies obtidas aleatoriamente da população em questão, então estimativas $\hat{\sigma}_{\mathrm{M}}^{2}$ e $\hat{\sigma}_{\mathrm{h}}^{2}$ podem ser obtidas pelo método dos momentos, utilizando uma análise de variância, e assim p pode ser estimado mediante: 


$$
\hat{p}=\frac{\hat{\sigma}_{M}^{2}}{\hat{\sigma}_{M}^{2}+\hat{\sigma}_{h}^{2}}
$$

A variação total entre unidades experimentais pode ser particionada conforme foi apresentado na Tabela 11.

$$
\begin{aligned}
& \text { O modelo (4.1), expresso em notação matricial, é: } \\
& \mathbf{y}=\mathbf{X} \theta+\mathbf{e}
\end{aligned}
$$

em que $y, \theta$ e e são os vetores das observações, de parâmetros e de resíduos, respectivamente, e $X$ é a matiz de incidência. Utilizando (4.4) e (4.5), tem-se que a matriz de dispersão $V$ de $y$, dado $m_{i}$ é:

$$
\mathbf{V}=\left[\begin{array}{ccccccc}
\sigma^{2}+\sigma_{h}^{2} & \sigma_{h}^{2} & \cdots & 0 & 0 & \cdots & 0 \\
\sigma_{h}^{2} & \sigma^{2}+\sigma_{h}^{2} & \cdots & 0 & 0 & \cdots & 0 \\
\vdots & \vdots & & \vdots & \vdots & & \vdots \\
0 & 0 & \cdots & \sigma^{2}+\sigma_{h}^{2} & \sigma_{h}^{2} & \cdots & 0 \\
0 & 0 & \cdots & \sigma_{h}^{2} & \sigma^{2}+\sigma_{h}^{2} & \cdots & 0 \\
\vdots & \vdots & & \vdots & \vdots & & \vdots \\
0 & 0 & \cdots & 0 & 0 & \cdots & \sigma^{2}+\sigma_{h}^{2}
\end{array}\right]
$$

A matriz seguinte:

$$
\mathbf{P}=\mathbf{X} \mathbf{X}^{+}
$$

na qual $\mathbf{X}^{+}$refere-se à inversa de Moore-Penrose, é conhecida como o projetor ortogonal associado ao modelo (4.10), que permite a obtenção do vetor de valores estimados mediante $\hat{\mathbf{y}}=\mathbf{P y}$. Seja $\mathbf{1}_{\mathbf{n}}$ a notação de um vetor $(\mathbf{n} \times 1)$ com todos os elementos iguais a 1. Assim, definindo:

$$
P_{1}=1_{n} 1_{n}^{+}
$$

então a soma de quadrados relativa a 'progênies' (Tabela 11), ajustada para a constante $\mu$, é (Searle, 1971): 


$$
S Q P=y^{\prime}\left(P-P_{1}\right) y
$$

De acordo com o modelo (4.3), a variação entre progênies pode ser particionada em uma soma de quadrados de regressão e outra relativa aos desvios de regressão. O modelo (4.3), em notação matricial, é:

$$
y=Z \beta+X \gamma+e
$$

no qual $Z$ e $X$ são matrizes de incidência, e $\beta$ e $\gamma$ são vetores de parâmetros associados e não associados (desvios) à regressão, respectivamente. Denotando por $\mathbf{P}_{\mathrm{R}}$ o projetor ortogonal referente à regressão, ou seja:

$$
\mathbf{P}_{\mathbf{R}}=\mathbf{Z Z} \mathbf{Z}^{+}
$$

tem-se então que a soma de quadrados de regressão é dada por:

$$
S Q R=y^{\prime}\left(P_{R}-P_{1}\right) y
$$

e a soma de quadrados dos desvios de regressão é calculada mediante:

$$
S Q D=y^{\prime}\left(P-P_{R}\right) y
$$

As formas quadráticas (4.17) e (4.18) são independentes, uma vez que $Z$ obviamente pertence ao espaço gerado pelas colunas da matriz $\mathbf{X}$. Ou seja:

$$
\left(P_{R}-P_{1}\right)\left(P-P_{R}\right)=\varnothing
$$

As esperanças das formas quadráticas (4.14), (4.17) e (4.18) podem assim ser obtidas (Searle, 1971):

$$
\begin{aligned}
& E[S Q P]=\operatorname{Tr}\left[\left(P_{-}-\mathbf{P}_{1}\right) \mathbf{V}\right]+\beta^{\prime} Z^{\prime} Z \beta=(t-1)\left(\sigma^{2}+r \sigma_{h}^{2}\right)+\beta^{\prime} Z^{\prime} Z \beta \\
& E[S Q R]=\operatorname{Tr}\left[\left(P_{R}-P_{1}\right) \mathbf{V}\right]+\beta^{\prime} Z^{\prime} Z \beta=k\left(\sigma^{2}+r \sigma_{h}^{2}\right)+\beta^{\prime} Z^{\prime} Z \beta \\
& E[S Q D]=\operatorname{Tr}\left[\left(P_{R}-P_{1}\right) \mathbf{V}\right]+\beta^{\prime} Z^{\prime} Z \beta=(t-k-1)\left(\sigma^{2}+r \sigma_{h}^{2}\right)
\end{aligned}
$$


A esperança da sọma de quadrados de progênies, ignorando a análise de regressão, corresponde ao resultado bem conhecido:

$$
E[S Q P]=(t-1)\left(\sigma^{2}+r \sigma_{G}^{2}\right)
$$

Igualando a primeira das expressões de (4.20) a (4.21), segue-se que:

$$
\sigma_{\mathrm{G}}^{2}=\sigma_{\mathrm{h}}^{2}+\frac{\beta^{\prime} \mathbf{Z} \mathbf{Z} \mathbf{\beta}}{\mathrm{r}(\mathrm{t}-1)}
$$

Substituindo a expressão (4.22) em (4.7), tem-se que o componente $\sigma_{M}^{2}$ pode ser expresso como:

$$
\sigma_{\mathrm{M}}^{2}=\frac{\beta^{\prime} \mathbf{Z}^{\prime} \mathbf{Z} \beta}{\mathrm{r}(\mathrm{t}-1)}
$$

Portanto, a esperança do quadrado médio associado à regressão é:

$$
E[Q M R]=\sigma^{2}+r \sigma_{h}^{2}+\frac{r(t-1)}{k} \sigma_{M}^{2}
$$

$\mathrm{Na}$ Tabela 16, estão apresentadas as esperanças de todos os quadrados médios, referentes às causas de variação: progênies, regressão, desvios de regressão e erro experimental. Estas esperanças podem ser utilizadas na estimação dos componentes de variância pelo método dos momentos:

$$
\begin{aligned}
& \hat{\sigma}^{2}=\mathrm{QME} \\
& \hat{\sigma}_{\mathrm{h}}^{2}=\frac{\mathrm{QMD}-\mathrm{QME}}{\mathrm{r}} \\
& \hat{\sigma}_{\mathrm{M}}^{2}=\frac{\mathrm{k}(\mathrm{QMR}-\mathrm{QMD})}{\mathrm{r}(\mathrm{t}-1)} .
\end{aligned}
$$


e assim a proporção da variância genética explicada por marcadores moleculares pode ser utilizada conforme a expressão (4.9), utilizando os estimadores em (4.25).

\subsubsection{Distribuição de Amostragem de $\hat{\mathbf{p}}$}

A distribuição de amostragem de estimadores corresponde a uma importante ferramenta para sua avaliação e comparação, bem como para a construção de intervalos de confiança. $O$ estimador $\hat{p}$ consiste, como foi visto, em uma função de quadrados médios, relativos a um modelo de regressão, aos desvios de regressão, e ao erro experimental. Em uma típica análise de regressão, o modelo é fixo, e assim as formas quadráticas têm distribuições associadas a qui-quadrados não-centrais, os quais são de difícil manipulação. No entanto, admitindo as causas de variação da Tabela 16 como tendo natureza aleatória, as distribuições das formas quadráticas são na realidade funções de qui-quadrados centrais. Sob normalidade e um modelo aleatório, tem-se que a quantidade pivotal y'Qy $\operatorname{Tr}[\mathbf{Q}]$ / E[y'Qy], na qual y'Qy denota uma forma quadrática, e $\operatorname{Tr}$ a operação "traço", tem distribuição de qui-quadrado com $\operatorname{Tr}[\mathbf{Q}]$ graus de liberdade (Searle, 1971). Com essas considerações, é possível obter a distribuição de amostragem de $\hat{\mathrm{p}}$. Para tanto, sejam definidas as variáveis $\mathrm{u}=$ SQR, $v=S Q D$ e $w=S Q E$, sendo que $S Q R, S Q D$ e SQE representam as somas de quadrados de regressão, dos desvios e do erro experimental, respectivamente. $\mathrm{O}$ estimador $\hat{\mathrm{p}}$ é uma função de tais variáveis, dada por: 


$$
\hat{p}=z=\frac{u-\frac{k}{(t-k-1)} v}{u+v-\frac{(t-1)}{t(r-1)} w}
$$

Sob normalidade, e admitindo o modelo (4.15) como aleatório, tem-se que as distribuições de $u, v$ e $w$ podem ser obtidas facilmente, sendo elas:

$f_{U}(u)=\frac{u^{\frac{k}{2}-1}}{2^{\frac{k}{2}} \Gamma\left[\frac{k}{2}\right]\left(\sigma^{2}+r \sigma_{h}^{2}+\frac{r(t-1)}{k} \sigma_{M}^{2}\right)^{\frac{k}{2}}} \exp \left\{-\frac{u}{2\left(\sigma^{2}+r \sigma_{h}^{2}+\frac{r(t-1)}{k} \sigma_{M}^{2}\right)}\right\}$

$f v(v)=\frac{v^{\frac{t-k-1}{2}-1}}{2^{\frac{t-k-1}{2}} \Gamma\left[\frac{t-k-1}{2}\right]\left(\sigma^{2}+r \sigma_{h}^{2}\right)^{\frac{t-k-1}{2}}} \exp \left\{-\frac{v}{2\left(\sigma^{2}+r \sigma_{h}^{2}\right)}\right\}$

$f_{W}(w)=\frac{w^{\frac{t(r-1)}{2}-1}}{2^{\frac{t(r-1)}{2}} \Gamma\left[\frac{t(r-1)}{2}\right]\left(\sigma^{2}\right)^{\frac{t(r-1)}{2}}} \exp \left\{-\frac{w}{2 \sigma^{2}}\right\}$

Uma vez que estas variáveis são independentes umas das outras, a sua distribuição conjunta é meramente o produto das densidades em (4.27). Além da transformação em (4.26), duas outras quaisquer podem ser definidas, por exemplo, $s=v$ e $x=w$. Assim, é definida uma transformação tri-dimensional, com Jacobiano dado por:

$$
J=(t-1)\left[\frac{s}{t-k-1}-\frac{x}{t(r-1)}\right]
$$

E assim a distribuição conjunta de $(z, s, x)$ é portanto: 


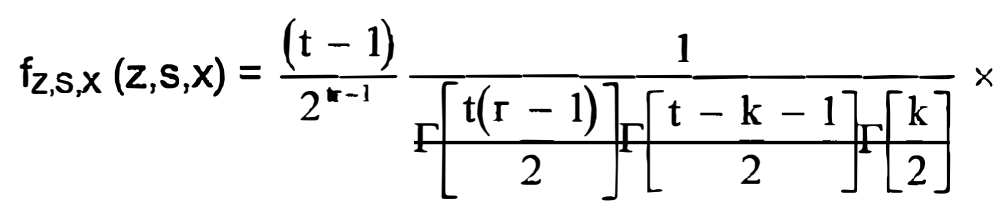

$$
\times \frac{1}{\sigma^{t(r-1)}\left(\sigma^{2}+r \sigma_{h}^{2}\right)^{\frac{t-k-1}{2}}\left(\sigma^{2}+r \sigma_{h}^{2}+\frac{r(t-1)}{k} \sigma_{M}^{2}\right)^{\frac{k}{2}}} x^{\frac{t(r-1)}{2}-1} s^{\frac{t-k-1}{2}-1} \times
$$$$
\times\left[z(t-1)\left[\frac{s}{t-k-1}-\frac{x}{t(r-1)}\right]+\frac{k}{t-k-1} s\right]^{\frac{k}{2}-1} \times
$$$$
x \exp \cdot\left[\frac{-[t(t-1)(r-1) z s-(t-1)(t-k-1) z x+t(r-1) k s]}{2 t(r-1)(t-k-1)\left(\sigma^{2}+r \sigma_{h}^{2}+\frac{r(t-1)}{k} \sigma_{M}^{2}\right)}-\frac{s}{2\left(\sigma^{2}+r \sigma_{h}^{2}\right)}-\frac{x}{\sigma^{2}}\right]
$$

Integrando (4.29) em relação a $s$ e a $x$, pode-se obter a distribuição de $\hat{p}$. Entretanto, não é possível obter uma expressão analítica para essa integral, o que é comum, no tocante a combinações lineares de qui-quadrados independentes (Fleiss, 1971). No entanto, para dados valores de $t, r, k, \sigma^{2}, \sigma_{h}^{2}$ e $\sigma_{M}^{2}$, a distribuição de $\hat{p}$ pode ser obtida por integração numérica ou por simulação computacional.

Uma desvantagem da densidade obtida a partir da integração de (4.29) em relação a s e a $x$ é a de que ela não pode ser diretamente utilizada para a construção de intervalos de confiança, pois envolve os parâmetros desconhecidos $\sigma^{2}, \sigma_{h}^{2}$ e $\sigma_{M}^{2}$. Entretanto, os momentos $E[\hat{p}]$ e V $[\hat{p}]$ podem ser aproximadamente obtidos, utilizando a expansão de Taylor da razão entre duas variáveis aleatórias (Mood et al., 1974). Assim, com 
estimadores apropriados desses momentos, intervalos de confiança poderiam ser construídos utilizando a aproximação normal.

Segundo Mood et al. (1974), a esperança da razão entre duas variáveis aleatórias $x$ e y pode ser aproximada por:

$$
E\left[\frac{x}{y}\right] \cong \frac{E[x]}{E[y]}-\frac{\operatorname{Cov}[x, y]}{E^{2}[x]}+\frac{E[x]}{E^{3}[y]} V[y]
$$

na qual $\operatorname{Cov}[x, y]$ representa a covariância entre $x$ e y. $O$ estimador $\hat{p}$ consiste em uma razão entre duas variáveis aleatórias $x$ e $y$, na qual $x=\hat{\sigma}_{M}^{2}$ e $y=\hat{\sigma}_{G}^{2}$. As esperanças de $x$ e $y$, assim definidas, são, respectivamente, $\sigma_{M}^{2}$ e $\sigma_{G}^{2}$. A variância de um quadrado médio é, conforme Searle (1971), igual a $2 E^{2}\left[y^{\prime} Q y\right]$ / $\operatorname{Tr}^{3}[Q]$. Assim, como os quadrados médios associados à variação entre progênies (QMP), e ao erro experimental (QME) são variáveis aleatórias independentes, segue-se que:

$$
\mathrm{V}[\mathrm{y}]=\frac{1}{\mathrm{r}^{2}}\{\mathrm{~V}[\mathrm{QMP}]+\mathrm{V}[\mathrm{QME}]\}=\frac{2}{\mathrm{r}^{2}}\left[\frac{\left(\sigma^{2}+\mathrm{r} \sigma_{\mathrm{h}}^{2}+\mathrm{r} \sigma_{\mathrm{M}}^{2}\right)^{2}}{\mathrm{t}-1}+\frac{\sigma^{4}}{\mathrm{t}(\mathrm{r}-1)}\right]
$$

Para o cálculo de $\operatorname{Cov}[x, y]=E[x y]-E[x] E[y]$, deve-se notar que:

$$
\begin{gathered}
x y= \\
=\frac{k}{r^{2}(t-1)}\left[\frac{S Q R+S Q D}{t-1} Q M R-\frac{S Q R+S Q D}{t-1} Q M D-Q M R \times Q M E+Q M D \times Q M E\right]
\end{gathered}
$$

Segue-se de (4.32) que: 


$$
\begin{aligned}
& E[x y]=\frac{k}{r^{2}(t-1)}\left[\mathrm{k}\left[\mathrm{V}[\mathrm{QMR}]+\mathrm{E}^{2}[\mathrm{QMR}]\right]+(\mathrm{t}-\mathrm{k}-1) \mathrm{E}[\mathrm{QMR}] \mathrm{E}[\mathrm{QMD}]\right. \\
& \mathrm{t}-1 \\
& \left.\frac{(\mathrm{t}-\mathrm{k}-1)\left[\mathrm{V}[\mathrm{QMD}]+\mathrm{E}^{2}[\mathrm{QMD}]\right]}{(\mathrm{t}-1)}-\mathrm{E}[\mathrm{QMR}] \mathrm{E}[\mathrm{QME}]+\mathrm{E}[\mathrm{QMD}] \mathrm{E}[\mathrm{QME}]\right]
\end{aligned}
$$

Tornando explícitas as esperanças e as variâncias dos quadrados médios em (4.33), pela utilização das esperanças da Tabela 16, tem-se que a covariância entre $x$ e y é:

$$
\operatorname{Cov}[x, y]=\frac{2 \sigma_{M}^{2}\left[2 k \sigma^{2}+2 k r \sigma_{h}^{2}+r(t-1) \sigma_{M}^{2}\right]}{k r(t-1)}
$$

Pela substituição de (4.31) e (4.34) em (4.30), segue-se que a esperança de $\hat{p}$ pode ser aproximada por:

$$
\begin{gathered}
E[\hat{p}] \cong \frac{\sigma_{M}^{2}}{\sigma_{G}^{2}}-\frac{2 \sigma_{M}^{2}\left[2 k \sigma^{2}+2 k r \sigma_{b}^{2}+r(t-1) \sigma_{M}^{2}\right]}{k r(t-1) \sigma_{G}^{4}}+ \\
\left.+\frac{2 \sigma_{M}^{2}\left[\left[\sigma^{2}+r \sigma_{G}^{2}\right]^{2}\right.}{r^{2} \sigma_{G}^{6}\left[\frac{\sigma^{4}}{t}[t-1)\right.}\right]
\end{gathered}
$$

No tocante à aproximação da variância da razão entre duas variáveis aleatórias, Mood et al. (1974) apresentam a seguinte expressão:

$$
V\left[\frac{x}{y}\right] \cong \frac{E^{2}[y] V[x]+E^{2}[x] V[y]-2 E[x] E[y] \operatorname{Cov}[x, y]}{E^{4}[y]}
$$

No caso de $\hat{p}$, mantendo a definição de $x$ e y dada anteriormente, tem-se que: 


$$
V[x]-\frac{2 k^{2}}{r^{2}(t-1)^{2}}\left[\frac{\left(\sigma^{2}+r \sigma_{h}^{2}+\frac{r(t-1)}{k} \sigma_{M}^{2}\right)^{2}}{k}+\frac{\left[\sigma^{2}+r \sigma_{h}^{2}\right]^{2}}{t-k-1}\right]
$$

Substituindo (4.31), (4.34) e (4.37) em (4.36), resulta:

$$
\begin{gathered}
\mathrm{V}[\hat{\mathrm{p}}] \cong \frac{2}{\sigma_{\mathrm{G}}^{6}}\left[\frac{\mathrm{k}^{2} \sigma_{\mathrm{G}}^{4}}{\mathrm{r}^{2}(\mathrm{t}-1)^{2}}\left[\frac{\left(\sigma^{2}+\mathrm{r} \sigma_{\mathrm{h}}^{2}+\frac{\mathrm{r}(\mathrm{t}-1)}{\mathrm{k}}-\sigma_{\mathrm{M}}^{2}\right)^{2}}{\mathrm{k}}+\frac{\left(\sigma^{2}+\mathrm{r} \sigma_{\mathrm{h}}^{2}\right)^{2}}{\mathrm{t}-\mathrm{k}-1}\right]+\right. \\
\left.+\frac{\sigma_{\mathrm{M}}^{4}}{\mathrm{r}^{2}}\left[\frac{\left[\sigma^{2}+\mathrm{r} \sigma_{\mathrm{G}}^{2}\right]^{2}}{\mathrm{t}-1}+\frac{\sigma^{4}}{\mathrm{t}(\mathrm{r}-1)}\right]-\frac{2 \sigma_{M}^{4}}{\mathrm{kr}(\mathrm{t}-1)} \sigma_{\mathrm{G}}^{2}\left[2 \mathrm{k} \sigma^{2}+2 \mathrm{kr} \sigma_{\mathrm{h}}^{2}+\mathrm{r}(\mathrm{t}-1) \sigma_{\mathrm{M}}^{2}\right]\right]
\end{gathered}
$$

Para a estimação de $\mathrm{V}[\hat{\mathrm{p}}]$, é importante notar que um estimador nãotendencioso e frequentemente utilizado da variância de um quadrado médio é, conforme (Searle, 1971), igual a $2 \mathrm{QM}^{2} /(\mathrm{f}+2)$, na qual $\mathrm{QM}$ representa um quadrado médio e f o seu número de graus de liberdade correspondente. Portanto, um estimador de $\mathrm{V}[\hat{\mathrm{p}}]$ pode ser obtido utilizando $2 \mathrm{QM}^{2} /(\mathrm{f}+2)$ ao invés de $2 E^{2}\left[y^{\prime} Q\right.$ y] / $\operatorname{Tr}^{3}[Q]$, nas expressões (4.31), (4.34) e (4.37), e quadrados médios de um experimento real no lugar de suas correspondentes esperanças, obtendo, assim, estimativas de $V[y]$, $\operatorname{Cov}[x, y]$ e de $V[x]$, como definidas acima. Substituindo-as em (4.36), segue-se que um tal estimador de V[p̂ ] é: 


$$
\begin{aligned}
& \hat{V}[\hat{p}]=\frac{2}{\hat{\sigma}_{G}^{6}}\left[\frac{k^{2} \hat{\sigma}_{G}^{4}}{r^{2}(t-1)^{2}}\left[\frac{\left(\hat{\sigma}^{2}+r \hat{\sigma}_{h}^{2}+\frac{r(t-1)}{k} \hat{\sigma}_{M}^{2}\right)^{2}}{k+2}+\frac{\left(\hat{\sigma}^{2}+r \hat{\sigma}_{h}^{2}\right)^{2}}{t-k+1}\right]+\right. \\
& +\frac{\hat{\sigma}_{M}^{4}}{r^{2}}\left[\frac{\left[\hat{\sigma}^{2}+r \hat{\sigma}_{G}^{2}\right]^{2}}{t+1}+\frac{\hat{\sigma}^{4}}{t(r-1)+2}\right]-\hat{\sigma}_{M}^{2} \hat{\sigma}_{G}^{2} \times \\
& x \\
& {\left[\frac { k } { [ r ^ { 2 } ( t - 1 ) ] } \left[\frac{k\left(\frac{k+4}{k+2}\right)\left(\hat{\sigma}^{2}+r \hat{\sigma}_{h}^{2}+\frac{r(t-1)}{k} \hat{\sigma}_{M}^{2}\right)^{2}+\frac{(t-k-1)(t-k+3)}{(t-k+1)}\left(\hat{\sigma}^{2}+r \hat{\sigma}_{h}^{2}\right)^{2}}{t-1}\right.\right.} \\
& \left.\left.\left.+\left(\hat{\sigma}^{2}+r \hat{\sigma}_{h}^{2}\right)\left(\hat{\sigma}^{2}+r \hat{\sigma}_{h}^{2}+\frac{r(t-1)}{k} \hat{\sigma}_{M}^{2}\right)-\frac{r(t-1)}{k} \hat{\sigma}_{M}^{2} \hat{\sigma}^{2}\right]-\hat{\sigma}_{M}^{2} \hat{\sigma}_{G}^{2}\right]\right]
\end{aligned}
$$

A Tabela 17 apresenta os valores de $E[\hat{p}]$ e de $V[\hat{p}]$, conforme expressões (4.35) e (4.38) acima, para $k=5$ locos marcadores, diferentes números de tratamentos e 2 repetições. Foram atribuídos 2 valores $(0,2$ e 0,8$)$ para a herdabilidade ao nível de médias de progênies, definida como em (4.16), da mesma forma que para $p(0,1$ e 0,9$)$. Se as aproximações puderem ser consideradas satisfatórias, pode-se observar nesta Tabela 17 que $\hat{p}$ apresenta tendenciosidades, que são maiores com números menores de progênies. Em tais casos (diga-se, até 100 progênies), os vícios são menores quando a herdabilidade é alta, para um valor de $p$ fixo. Sob baixa herdabilidade, a esperança aproximada de $\hat{p}$ se aproxima de $p$ mais rapidamente, com $o$ aumento do tamanho da amostra (número de tratamentos), quando este 
parâmetro é baixo $(0,1)$. Sob alta herdabilidade, aparentemente esta diferença de tendências não ocorre. A magnitude das variâncias são sempre menores com $h^{2}=0,8$, para valores fixos de $p$. Além disso, para um dado número de progênies, esta magnitude cresce, à medida que $p$ passa de 0,1 para 0,9 , sob baixa herdabilidade $(0,2)$. Se este último parâmetro é alto, então uma tendência oposta pode ser observada.

É preciso dizer que uma avaliação assim de $\hat{\mathrm{p}}$, baseadas em aproximações de $E[\hat{p}]$ e de $V[\hat{p}]$, é algo grosseira, principalmente com números pequenos de progênies, no sentido de que não se pôde separar até que ponto as maiores tendenciosidades e a menor precisão são reais, ou são devido à pior qualidade de tais aproximações. Para abordar esse aspecto, uma simulação de Monte Carlo da distribuição de $\hat{p}$ foi realizada. Nas Figuras 5 e 6 estão apresentados os polígonos de frequência referente à geração de 5000 valores aleatórios, conforme (4.26), para uma amostra pequena $(t=10$ progênies e 2 repetições), $k=5$ locos marcadores, e herdabilidade igual a 0,2 (Figura 5) e 0,8 (Figura 6). Também foram atribuídos dois valores para $p(0,1$ e $0,9)$. Também nas mesmas Figuras estão apresentadas as aproximações normais da distribuição de $\hat{p}$, utilizando os valores de $E[\hat{p}]$ e de $V[\hat{p}]$ correspondentes, da Tabela 17. Sob baixa herdabilidade (Figura 5), a aproximação é bastante pobre, tornando-se pior à medida que $p$ aumenta. Se aquele parâmetro aumenta (Figura 6), contudo, então existe uma razoável concordância entre os valores gerados pela simulação de Monte Carlo e a aproximação normal. Estes resultados sugerem, assim, que, sob alta herdabilidade, a distribuição normal possa ser utilizada para a construção de intervalos de confiança aproximados. 


\subsubsection{Distribuição de Amostragem de $\mathbf{R}^{2}$}

A estatística mais frequentemente utilizada para quantificar a proporção da variação explicada por marcadores moleculares é o coeficiente de determinação $\left(R^{2}\right)$. A sua distribuição de amostragem pode ser obtida de maneira semelhante à empregada para $\hat{p}$. Novamente, não se justifica o uso de qui-quadrados não-centrais. Em termos das variáveis $u$ e $v$ definidas anteriormente, tem-se que $R^{2}=u /(u+v)$. Com a transformação adicional $s=v$, tem-se que o jacobiano correspondente é:

$$
J=\frac{s}{(1-z)^{2}}
$$

A distribuição de $(z, s)$ é, portanto:

$$
\begin{aligned}
& f_{z, S}(z, s)=\frac{1}{2^{\frac{k}{2}} \Gamma\left[\frac{k}{2}\right]\left(\sigma^{2}+r \sigma_{h}^{2}+\frac{r(t-1)}{k} \sigma_{M}^{2}\right)^{\frac{k}{2}} 2^{\frac{t-k-1}{2}} \Gamma\left[\frac{t-k-1}{2}\right]\left(\sigma^{2}+r \sigma_{h}^{2}\right)^{\frac{t-k-1}{2}}} \times \\
& \left.\times \frac{(z s)^{\frac{k}{2}-1} s^{\frac{t-k-1}{2}-1}}{(1-z)^{\frac{k}{2}-1}} \exp \mid-\frac{z s}{2\left(\sigma^{2}+r \sigma_{h}^{2}+\frac{r(t-1)}{k} \sigma_{M}^{2}\right)(1-z)}\right] \times \\
& x \exp \left\{-\frac{s}{2\left(\sigma^{2}+r \sigma_{h}^{2}\right)}\right\} \frac{s}{(1-z)^{2}}
\end{aligned}
$$

Integrando (4.41) em relação a s, tem-se que: 


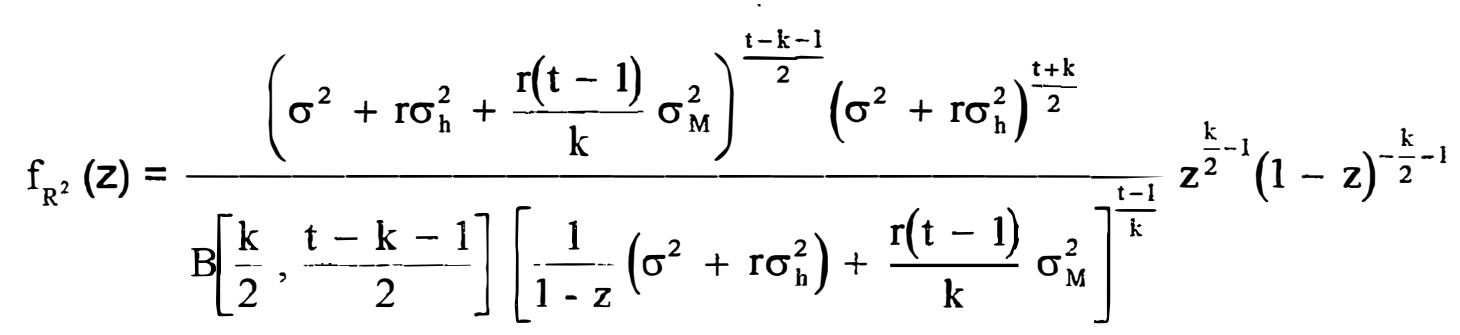

A distribuição de $R^{2}$ também está apresentada nas Figuras 5 e 6, nas mesmas condições consideradas para a geração da distribuição de $\hat{\mathrm{p}}$. Pode-se ver na Figura 5 que, com $\mathrm{p}=0,1$, ambas as estatísticas são aparentemente inapropriadas para expressar a proporção da variância genética explicada por marcadores moleculares. O coeficiente de determinação é marcadamente tendencioso, no sentido de superestimar p. Uma vez que o numerador de $\mathrm{R}^{2}$ é a soma de quadrados de regressão, ele deve estar sendo inflacionado pelos fatores ambientais e genéticos não-associados a marcadores moleculares. Por outro lado, o estimador $\hat{p}$ aparenta ter uma moda próxima de $p$ $=0,1$, mas claramente apresenta uma baixissima precisão (alto erro quadrático médio). Mais de $80 \%$ dos valores gerados pela simulação estiveram fora do espaço paramétrico, o intervalo $[0,1]$. Na situação com $p=0,1$, na Figura 5 , o coeficiente de determinação é claramente um melhor estimador, ainda que com uma certa tendenciosidade, agora no sentido de subestimar p. Na Figura 6, referente a situações de alta herdabilidade, o estimador $\hat{p}$ possui igualmente baixa precisão. O coeficiente apresenta um vício considerável, com $p=0,1$, mas parece ser adequado com $p=0,9$. De uma forma geral, os resultados em conjunto das Figuras 5 e 6 sugerem que, sob pequenos números de progênies, as estatísticas $R^{2}$ e $\hat{p}$ são ambas insatisfatórias para quantificar a proporção da variância genética explicada por marcadores moleculares, a menos que $p$ ou tanto $\mathrm{p}$ quanto $\mathrm{h}^{2}$ sejam elevados. Em tais casos, o coeficiente de determinação deveria ser preferido. 
A Figura 7 apresenta as distribuições de amostragem de $\hat{p}$ e $R^{2}$, sob um tamanho de amostra elevado $(t=400)$ e baixa herdabilidade ao nível de médias de progênies $\left(h^{2}=0,2\right)$. A precisão de $\hat{p}$ é consideravelmente maior do que aquela com tamanho de amostra reduzido (Figura 5). Há igualmente uma tendência clara desse estimador tornar-se menos preciso, quando $p$ passa de 0,1 para 0,9 . Isto também pôde ser observado na Tabela 17 , na maioria das situações com $\mathrm{h}^{2}=0,2$. O coeficiente de determinação apresenta uma forte tendenciosidade, no sentido de subestimar $p$, quando este parâmetro é igual a 0,1 (Figura 7). Isto deve ser um reflexo do fato de esta estatística ser uma razão de somas de quadrados; assim, com altos valores de $t$ (em relação ao número de marcadores $\mathrm{k}$ ), é elevado o número de graus de liberdade dos desvios de regressão, inflacionando o denominador de $\mathrm{R}^{2}$.

No estudo de características quantitativas com a utilização de marcadores, o melhorista com frequência se defronta com situações semelhantes às da Figura 7 , no sentido de que a herdabilidade é geralmente baixa, e o número de progênies avaliadas compreende, não raramente, de algumas a várias centenas. Além disso, mesmo que o número de marcadores seja inicialmente elevado, eles são frequentemente testados em separado, ou, quando não, técnicas de seleção de variáveis para a construção de modelos de regressão múltipla ("backward", "stepwise", etc.) são por vezes utilizadas, o que reduz sensivelmente o número final de marcas utilizadas no estudo. Assim, considerando as circunstâncias sob as quais a Figura 7 foi construída como típicas, então pode-se dizer que estimador $\hat{\mathrm{p}}$ seria mais apropriado na maioria das situações. 


\subsubsection{Uso de $\hat{\mathbf{p}}$ na SAM}

Conforme a expressão (2.17), é evidente que para a utilização do índice de seleção de Lande \& Thompson (1990) são necessárias estimativas de $\mathrm{p}$ e de $\mathrm{h}^{2}$. O coeficiente de determinação já foi sugerido como um estimador de p para fins de seleção assistida por marcadores (Gimelfarb \& Lande, 1994a,b). Se as unidades de seleção são progênies avaliadas com repetições, e em grande número (diga-se, algumas centenas), então a estatística $\hat{p}$ deve ser preferida para a estimação do coeficiente $b_{M}$ associado ao escore molecular, em (2.9), pelas razões apontadas no item anterior.

Este coeficiente estimado, $\hat{b}_{\mathrm{M}}, \mathrm{e}$ algumas de suas implicações de seu uso na seleção assistida por marcadores podem ser investigadas através de sua distribuição de amostragem. Se as unidades de seleção são progênies avaliadas em repetições, então a herdabilidade empregada em $\left(b_{M}\right)$ deve ser aquela ao nível de médias de progênies, ou seja, $H^{2}=\hat{\sigma}_{G}^{2} /\left(\hat{\sigma}_{G}^{2}+\hat{\sigma}^{2} / r\right)$. Como $\hat{p}=\hat{\sigma}_{M}^{2} / \hat{\sigma}_{G}^{2}$, e além disso $\hat{\sigma}_{G}^{2}=\hat{\sigma}_{h}^{2}+\hat{\sigma}_{M}^{2}$, tem-se que $\hat{b}_{M}$ pode ser expresso como:

$$
\hat{b}_{M}=\frac{\hat{\sigma}^{2}}{r \hat{\sigma}_{h}^{2}}
$$

Assim, da mesma forma que $\hat{p}$ e $R^{2}$, o estimador $\hat{b}_{M}$ é uma função de quadrados médios. Utilizando as variáveis $u$ e $v$ definidas em (4.26), tem-se que

$$
\hat{b}_{M}=z=v /(u-v)
$$

Definindo uma outra transformação de $(u, v)$, por exemplo $s=v$, tem-se que o jacobiano dessa transformação bidimensional é:

$$
\mathrm{J}=\frac{\mathrm{s}}{\mathrm{z}^{2}}
$$


Assim, a distribuição conjunta de $(z, s)$ é:

$$
\begin{aligned}
& f_{z, s}(z, s)=\frac{1}{2^{\frac{k}{2}} \Gamma\left[\frac{k}{2}\right]\left(\sigma^{2}+r \sigma_{h}^{2}+\frac{r(t-1)}{k} \sigma_{M}^{2}\right)^{\frac{k}{2}} 2^{\frac{t(r-1)}{2}} \Gamma\left[\frac{t(r-1)}{2}\right]\left(\sigma^{2}\right)^{\frac{t(r-1)}{2}}} \times \\
& \times s^{\frac{t(r-1)}{2}-1}\left[s\left(\frac{1}{z}+1\right)\right]^{\frac{t-k-1}{2}-1} \exp \left\{-s\left[\frac{1}{z}+1\right] \frac{r(t-k-1)}{2\left(\sigma^{2}+r \sigma_{h}^{2}\right)}\right\} \exp \left\{-\frac{t r(r-1)}{2 \sigma^{2}} s\right\} \frac{s}{z^{2}}
\end{aligned}
$$

Integrando (4.46) com relação a s, resulta a seguinte distribuição de amostragem de $\hat{b}_{M}$ :

$$
\begin{gathered}
f_{\hat{b}_{M}}(z)=\frac{[\mathrm{r}(\mathrm{t}-\mathrm{k}-1)]^{\frac{\mathrm{t}-\mathrm{k}-1}{2}-1}[\operatorname{tr}(\mathrm{r}-1)]^{\frac{\mathrm{t}(\mathrm{r}-1)}{2}}}{2^{\frac{\mathrm{tr}-\mathrm{k}-1}{2}} \mathrm{~B}\left[\frac{\mathrm{t}-\mathrm{k}-1}{2}, \frac{\mathrm{t}(\mathrm{r}-1)}{2}\right]\left[\sigma^{2}+\mathrm{r} \sigma_{\mathrm{h}}^{2}\right]^{\frac{\mathrm{t}-\mathrm{k}-1}{2}} \sigma^{\mathrm{t}(\mathrm{r}-1)}} \times \\
\times \frac{\left[\frac{1}{\mathrm{z}}+1\right]^{\frac{\mathrm{t}-\mathrm{k}-1}{2}-1}}{\mathrm{z}^{2}\left[\left(\frac{1}{\mathrm{z}}+1\right) \frac{\mathrm{r}(\mathrm{t}-\mathrm{k}-1)}{2\left(\sigma^{2}+\mathrm{r} \sigma_{\mathrm{h}}^{2}\right)}+\frac{\operatorname{tr}(\mathrm{r}-1)}{2 \sigma^{2}}\right]^{\frac{\mathrm{t}-\mathrm{k}-1}{2}+\frac{\mathrm{t}(\mathrm{r}-1)}{2}}}
\end{gathered}
$$

Uma vez que as estimativas $\hat{\sigma}_{\mathrm{h}}^{2}$ podem ser negativas, $\hat{b}_{\mathrm{M}}$ também pode. A Figura 8 apresenta a aparência de densidade (4.47), considerando um alto e um baixo valores de $b_{M}$ (iguais a 40 e a 1 , respectivamente. No primeiro caso, existe uma alta probabilidade de $\hat{b}_{M}$ ser negativo. É comum atribuir o valor zero à estimativa de um componente de variância, quando o valor fornecido pelo método dos momentos é negativo. Se $\hat{\sigma}_{\mathrm{h}}^{2}$ é considerado nulo, então $\hat{b}_{\mathrm{M}}$ tende ao infinito, ou seja, a seleção é baseada exclusivamente na informação molecular. Valores altos ou negativos de $\hat{b}_{M}$ 
podem ocorrer quando uma ampla fração da variância genética é explicada por marcadores e/ou a herdabilidade é muito baixa.

$\mathrm{O}$ coeficiente $\hat{b}_{\mathrm{M}}$ é um peso relativo, em relação àquele conferido à informação fenotípica. Se $\hat{b}_{M}$ é alto (diga-se, maior que 10), então a seleção será virtualmente toda baseada no escore molecular. Em situações como a da situação (a) da Figura 8, a informação fenotípica raramente irá desempenhar um papel relevante na seleção assistida por marcadores. $\mathrm{Na}$ situação (b), por outro lado, os valores de $\hat{b}_{M}$ são pequenos, refletindo uma baixa $p$ e/ou uma alta herdabilidade. Em tais casos, $\hat{b}_{M}$ irá quase certamente recair entre 0,5 e 2 , e assim tanto a informação fenotípica como a molecular serão importantes no processo seletivo.

\subsection{Avaliação da SAM em Espécies Autógamas}

\subsubsection{SAM Utilizando Progênies $S_{1}$}

O ganho com a seleção assistida por marcadores na simulação de 6 ciclos seletivos, e sua eficiência em relação à seleção baseada na média fenotípica de progênies, estão apresentados na Tabela 18 , bem como outros parâmetros de interesse, considerando a herdabilidade $h^{2}$ entre plantas $S_{0}$ do ciclo 0 como igual a 0,05 , sistema precoce de obtenção de progênies, efeitos aditivos somente e proporção de progênies selecionadas por cruzamento igual a $5 \%$. 
Para melhor compreender como a Tabela 18 foi construída, os passos detalhados de sua elaboração serão apresentados a seguir. $\mathrm{Na}$ Tabela 19 estão contidas informações referentes à avaliação das progênies das 5 subpopulações do ciclo 0 , tomadas de uma das 10 repetições que o processo foi simulado. A média dos valores obtidos, nas 5 subpopulações, de $H^{2}, k, \hat{p}, R^{2}$ e do valor genotípico da geração $S_{0}$ do ciclo 0 estão apresentados na Tabela 20. Também aí, estão apresentadas as médias desses parâmetros, nas 5 subpopulações, para os ciclos 1 a 6 . Finalmente, nesta mesma Tabela 20 estão contidas estas mesmas médias, para as 9 repetições restantes, em que o processo seletivo todo foi simulado. Calculando as médias dos parâmetros acima, a partir dessas 10 repetições, obtém-se os dados apresentados na Tabela 18. Assim, por exemplo, o valor referente a $\mathrm{H}^{2}$ do ciclo 0 , igual a 0,231 , foi calculado a partir de 50 valores ( 5 cruzamentos $\times 10$ repetições). Os desvios padrões observados estão entre parênteses, na Tabela 18. Para calcular a eficiência realizada da seleção assistida por marcadores, foi preciso igualmente calcular a média genotípica nos diversos ciclos seletivos na população simulada onde não se utilizou informação molecular. Os valores dessas médias genotípicas, em cada uma de 10 repetições, estão apresentadas na Tabela 21.

No ciclo 0 , o valor observado da herdabilidade média ao nível de progênies $S_{1}(0,231)$, foi maior do que $o$ de $h^{2}$, em virtude da menor variância fenotípica, decorrente do uso de parcelas e de repetições. Este aumento é tanto maior quanto maior for o coeficiente de heterogeneidade do solo de Smith (1938), que aqui foi tido como médio $(b=0,5)$. Neste mesmo ciclo, o número médio de marcas com coeficientes de regressão correspondentes estatisticamente significativos foi igual a 11,02 (Tabela 18). 0 ajuste a estes modelos de regressão foi tal que $88,1 \%$ da variância genética foi explicada pelos marcadores, em média. Nota-se que 0 coeficiente de determinação $\left(R^{2}\right)$ foi em média consideravelmente menor que $\hat{p}(24,7 \%)$, 
ilustrando os aspectos discutidos no item 4.1.3, referente a situações nas quais o número de progênies é elevado.

A seleção assistida por marcadores no primeiro ciclo seletivo ocasionou um ganho estatisticamente superior ao da seleção fenotípica (Tabela 18), sendo sua eficiência em média igual a 1,491. A expressão (2.18), que fornece a eficiência esperada Es com a seleção assistida por marcadores, pode ser calculada utilizando os valores de $\mathrm{H}^{2}$ e $\hat{\mathrm{p}}$ apresentados na Tabela 18. Estes valores, apesar de serem estimativas, foram calculados com alta precisão, em virtude do uso de 10 repetições, fornecendo assim uma boa aproximação. $\mathrm{Na}$ Tabela 18, os valores de Es assim calculados estão apresentados para todos os ciclos seletivos. No ciclo 1, esperar-se-ia uma eficiência igual a 1,957 , que é maior que a realizada $(1,491)$. Isso ilustra a perda ocasionada em virtude do fato de os coeficientes do índice de seleção terem de ser estimados, conforme discutido no item 2.4 .

A herdabilidade ao nível de médias de progênies $S_{1}$ aumentou no ciclo 2 para 0,382 , o que foi um reflexo da quantidade maior de QTL's segregando, uma vez que o número de linhagens ancestrais passou de 2 , no ciclo anterior, para 4, conforme o esquema da Figura 4. O número de marcas com coeficientes de regressão estatisticamente significativos subiu para 21,78, o que igualmente deve ter sido consequência deste aumento de variabilidade, no tocante a um aumento no número de marcas polimórficas. Apesar disso, houve no ciclo 2 uma drástica redução da eficiência da seleção assistida por marcadores, igual a 1,074 (Tabela 18). A eficiência esperada nesse ciclo, considerando os valores médios de $\mathrm{H}^{2}$ e de $\hat{\mathrm{p}}$ como boas aproximações dos valores paramétricos, é igual a 1,420. A diferença entre as eficiências esperada e observada foi comparável àquela do ciclo 1 (da ordem de 40\%). Na realidade, do ciclo 2 em diante, houve uma nítida tendência de queda de eficiência. $A$ Figura 9 ilustra o aumento na média das populações simuladas ao longo dos 6 ciclos seletivos utilizando e não utilizando marcadores moleculares. Pode-se 
visualizar que suas taxas de incremento mantiveram-se muito próximas, a partir do ciclo 1.

As perdas de eficiência a partir do ciclo 2 são um reflexo dos aumentos em $\mathrm{H}^{2}$ e diminuições em $\hat{\mathrm{p}}$ do ciclo 1 em diante (Tabela 18), conforme visto em (2.20). Para melhor compreender a natureza dessa alteração nesses parâmetros, foram apresentados, na Tabela 22, valores referentes à correlação entre os escores moleculares e o valor genotípico associados às progênies, a raiz quadrada de $\mathrm{H}^{2}$ observada na seleção fenotípica, o desequilíbrio de ligação médio em cada ciclo, e a proporção de locos marcadores e QTL's com alelos fixados. Para bem entender como a Tabela 22 foi construída, estão apresentadas as estimativas desses parâmetros, em cada uma das 10 repetições da seleção fenotipica e assistida por marcadores, nas Tabelas 20 e 21. Os valores da Tabela 22 consistem de médias calculadas a partir daquelas Tabelas, sendo os desvios padrões também apresentados.

No ciclo 0 a proporção de QTL's com alelos desfavoráveis fixados foi sempre igual a 0,6, em virtude do sistema escolhido para a formação da população base, ou seja, utilizando linhagens com $20 \%$ de locos com alelos favoráveis fixados, e cruzadas entre si cuidando que um certo nivel de dissimilaridade de 0,40 fosse mantido. $\mathrm{O}$ aumento em $\mathrm{H}^{2}$, como já comentado, foi um reflexo do aumento de variabilidade, por sua vez devido à recombinação nos primeiros ciclos seletivos. Isso também pôde ser visualizado na Tabela 22 , pela diminuição da proporção de QTL's com alelos desfavoráveis fixados, de 0,60 no ciclo 1 a 0,2 no ciclo 2 . Esta proporção diminuiu para valores próximos de 0 a partir do ciclo 3 .

Com base nos dados apresentados da Tabela 22, parece bastante razoável inferir que a diminuição ocorrida em $\hat{p}$, a partir do ciclo 1 (Tabela 18) foi devida à diminuição do desequilíbrio de ligação. Uma eventual 
redução no número de marcas polimórficas não deve ter contribuído para essa tendência, pois a proporção de locos marcadores com alelos fixados após o ciclo 1 diminuiu e manteve-se menor que $10 \%$ até o ciclo 5 (Tabela 22). Além disso, o número de marcas com coeficientes de regressão significativos aumentou (Tabela 18).

A diminuição no desequilíbrio de ligação com o passar de ciclos seletivos é um fato bem conhecido em plantas alógamas, e que prejudica a seleção assistida por marcadores, quando a população base é formada pelo cruzamento entre duas linhagens endogâmicas (por exemplo, Gimelfarb \& Lande, 1994a,b). Neste caso, a diminuição do desequilíbrio é devida exclusivamente à ocorrência de permuta genética. Esperava-se, contudo, que este aspecto tivesse um menor impacto em plantas autógamas, uma vez que progênies endogâmicas são utilizadas como unidades de seleção (no presente caso, progênies $S_{1}$ ). Neste estudo, 5 linhagens endogâmicas foram utilizadas para formar a população base, sendo que, entre os 5 cruzamentos iniciais, certamente ocorriam diferentes fases de ligação entre QTL's e locos marcadores. A partir do ciclo 1, no processo de recombinação, 20 progênies selecionadas de cada cruzamento eram cruzadas com 20 progênies selecionadas de outro cruzamento. Isso deve ter provocado uma "mistura" de fases de ligação, contribuindo para as reduções no desequilíbrio apresentadas na Tabela 22.

Pode parecer, à primeira vista, que este problema só ocorreu em virtude do esquema de seleção recorrente escolhido neste estudo. Contudo, deve-se ter em mente que, sempre que se utilizar mais do que 2 linhagens para se formar a população base, essa redução de desequilíbrio de ligação, pela mistura de diferentes fases, estará presente em menor ou maior grau, no processo de recombinação. Ou seja, ainda que a permuta genética não contribuísse para diminuir o desequilíbrio, ao longo dos ciclos seletivos, essa redução deverá ocorrer. Uma forma de atenuar este problema seria a de 
selecionar uma única linhagem endogâmica em cada subpopulação. Assim, ao longo dos ciclos seletivos, as subpopulaçōes seriam sempre formadas a partir do cruzamento entre 2 linhagens. Este aspecto será discutido em itens posteriores deste Capítulo 'Resultados e Discussão'.

É prudente salientar que trabalhos preliminares envolvendo simulação, e atestando a eficiência da seleção assistida por marcadores em maior ou menor grau (Edwards \& Page, 1994; Gimelfarb \& Lande 1994a,b; Ferreira, 1995), simularam a formação da população base pelo cruzamento entre 2 linhagens endogâmicas. Este esquema corresponde a um tamanho efetivo igual a 1 , o que não é comum em programas de melhoramento envolvendo seleção recorrente. Na relação de programas apresentados na Tabela 5, existe uma única referência reportando o uso de apenas 2 linhagens para formar a população base.

A diminuição no nível de desequilíbrio de ligação deve ter sido igualmente o fator responsável pela redução, a partir do ciclo 1 , na correlação entre os escores moleculares e os valores genotípicos associados às progênies (Tabela 22). Este parâmetro é comparável à raiz quadrada da herdabilidade, por esta corresponder à correlação entre o fenótipo e o genótipo das unidades de seleção. À exceção do ciclo 0 , este parâmetro foi sempre maior que o primeiro, evidenciando a maior informação sobre o valor genotípico existente no fenótipo, em relação àquela no escore molecular.

A falta de eficiência da seleção assistida por marcadores a partir do ciclo 1 toma-se ainda mais surpreendente, face ao fato de a proporção da variância genética explicada por marcadores ter estado sempre em torno ou acima de 0,7 (Tabela 18). Também é interessante notar como o coeficiente de determinação $\left(R^{2}\right)$ fornece a falsa impressão de os marcadores moleculares terem explicado uma pequena fração da variação genética, após o ciclo 1 , a julgar pelos menores valores dessa estatística. 
Neste estudo, optou-se por não apresentar como resultados os valores médios de $\hat{b}_{M}$, em virtude da elevada variância dessa estatística (coeficientes de variação acima de $100 \%$ foram frequentes). Para se ter uma idéia dessa dispersão, na Figura 10 está apresentada a distribuição de amostragem observada para essa estatística, nas 10 repetições da simulação da seleção assistida por marcadores, referentes ao ciclo 0 apenas. Trata-se de uma distribuição, portanto, gerada a partir de $\mathbf{5 0}$ valores. Nota-se de fato uma alta variabilidade, e uma semelhança com a Figura 8, para a situação em que o valor de $b_{M}$ é igual a 40 . Os valores em geral altos de $b_{M}$ foram neste caso um reflexo dos altos valores de $\hat{p}$, e dos valores comparativamente menores de $\mathrm{H}^{2}$ (em relação aos ciclos posteriores). Obviamente, nas situações em que $\hat{b}_{M}$ foi negativo, a seleção foi baseada exclusivamente na informação molecular, a menos que houvesse empates quanto ao escore molecular. Nestes casos, o valor fenotípico era o critério de desempate.

\subsubsection{Efeito de $h^{2}$ na Eficiência da SAM}

Os resultados referentes à avaliação da seleção assistida por marcadores, com herdabilidade inicial ao nivel de plantas $S_{0}$ igual a 0,025 e 0,1 , efeitos aditivos somente, sistema precoce de obtenção de progênies, e proporção de progênies selecionadas igual a $5 \%$, estão apresentados nas Tabelas 23 a 26, e Figuras 11 e 12.

Da mesma maneira que nas Tabelas 18 e 22, os valores das Tabelas 23 a 26 foram calculadas a partir de 10 repetições da simulação de 6 ciclos de seleção assistida por marcadores e 10 repetições referentes à seleção fenotípica. Conforme observa-se nas Tabelas 23 e 24 , a seleção 
assistida por marcadores só apresentou uma eficiência expressiva no primeiro ciclo seletivo. Do mesmo modo como observado no item 4.2.1, a partir do ciclo 2, a eficiência caiu para valores próximos ou abaixo de 1. Este aspecto também pode ser visualizado nas Figuras 11 e 12, que mostram curvas quase paralelas a partir do ciclo 2. Quando a herdabilidade foi igual a 0,1 , as curvas foram particularmente próximas (Figura 12).

No caso em que $h^{2}=0,025$, a redução de eficiência do ciclo 1 para o ciclo 2 foi bastante evidente, de 1,735 para 1,020. Considerando apenas os resultados referente ao ciclo 1 , nota-se que, com herdabilidades iguais a $0,025,0,05$ e 0,1 , a eficiência apresentou uma nítida tendência de queda, tendo sido igual a 1,735, 1,420 e 1,343, respectivamente (Tabelas 18, 23 e 24). Isso reforça o aspecto de que, se a herdabilidade da característica em questão for de moderada a alta, pouca vantagem haverá na utilização de marcadores, ainda que em um único ciclo seletivo.

De uma forma geral, de acordo com as Tabelas 23 a 26 , tendências semelhantes com aquelas das Tabelas 18 e 22 foram observadas, com relação a outros aspectos. A partir do ciclo 1 , há um considerável aumento de variabilidade e do número de marcas com coeficientes de regressão estatisticamente significativos. Entretanto, a proporção da variância genética explicada pelos marcadores caiu a partir do ciclo 1 (Tabelas 23 e 24). Os resultados apresentados nas Tabelas 25 e 26 evidenciam que também aqui a diminuição do desequilíbrio deve ter sido o principal fator da redução de $\hat{p}$. Este fato ocorreu mesmo com uma proporção muito baixa de locos marcadores com alelos fixados, a partir do ciclo 3 , menor que $10 \%$ até o ciclo 5 em ambos os casos. A semelhança desses resultados com os da Tabela 22 deve em grande parte ter se devido ao fato de que, em todos esses casos, a proporção de progênies selecionadas era a mesma (5\%), o que deve ter ocasionado a mistura de fases de ligação de maneira semelhante, no processo de recombinação. 
Considerando a situação em que $\mathrm{h}^{2}$ foi igual a 0,025 (Tabela 25), observa-se que, embora a correlação entre o escore molecular e o valor genotípico tenha sido em geral maior que a raiz quadrada de $\mathrm{H}^{2}$, os valores guardaram uma proximidade muito maior a partir do ciclo 1 . Com $\mathrm{h}^{2}$ igual a 0,1, a partir do ciclo 1 , os valores estiveram quase sempre abaixo da raiz quadrada da herdabilidade ao nível de médias de progênies, na seleção fenotípica. A fixação de QTL's com alelos favoráveis foi consideravelmente baixa até o ciclo 6 em quaisquer dos casos (Tabelas 25 e 26). Isso ilustra que ganhos adicionais ainda poderiam ser obtidos em ciclos subsequentes. A aparência das curvas nas Figuras 11 e 12, sem a ocorrência clara de assíntotas, ilustra igualmente este aspecto.

É interessante notar que, com $\mathrm{h}^{2}=0,025$, uma comparação pode ser feita com uma das modalidades de simulação do estudo de Gimelfarb \& Lande (1994a). Apesar de esses autores terem trabalhado com uma espécie alógama fictícia, os resultados em apenas 1 ciclo seletivo podem ser comparados com os do presente estudo, uma vez que compuseram cada população a partir do cruzamento entre duas linhagens endogâmicas, da mesma forma ao feito aqui em cada uma das 5 subpopulaçôes do ciclo 0 . Utilizando, como aqui, a avaliação de 400 unidades de seleção (200 indivíduos de cada sexo), e herdabilidade correspondente igual a 0,10 (próximo ao valor de 0,135 encontrado aqui para o ciclo 1, conforme Tabela 10), Gimelfarb \& Lande (1994) observaram no primeiro ciclo seletivo valores de eficiência de 1,70 a 1,82, conforme a fase de ligação entre QTL's ter sido de total repulsão ou total associação. A eficiência observada aqui foi igual a 1,735 , um valor bastante semelhante e intermediário entre aqueles apresentados acima. 


\subsubsection{SAM Utilizando Progênies $S_{3}$}

Nas Tabelas 27 e 28 estão apresentados resultados referentes à utilização do sistema avançado de obtenção de progênies na seleção assistida por marcadores moleculares, com $h^{2}$ igual a 0,025 , ausência de dominância, e proporção de progênies selecionadas igual a 5\%. O sistema avançado, conforme apresentado no Capítulo 'Metodologia', utiliza progênies $S_{3}$ como unidades de seleção, e um número de plantas por parcela igual a 30 . 0 valor da herdabilidade ao nível de médias de progênie foi igual a 0,307 no ciclo 0 (Tabela 27), o qual foi maior que aquele correspondente da Tabela 23, igual a 0,124 , nas mesmas condições, mas com unidades de seleção que corresponderam a progênies $S_{1}$. Nos ciclos subsequentes, esse tipo de comparação conduz a resultados semelhantes. Por outro lado, comparando ainda as Tabelas 23 e 27, observa-se que a proporção da variância genética explicada por marcadores foi menor em todos os ciclos, ao se utilizar progênies $\mathrm{S}_{3}$, mesmo com o aumento dos números de marcas com coeficientes de regressão significativos, e dos coeficientes de determinação. Ou seja, o aumento de precisão melhorou o poder do teste para a detecção de marcas, mas esta melhoria não foi proporcional ao aumento da variabilidade genética, provocada pelo aumento da endogamia.

Aparentemente, o efeito conjunto do aumento de $\mathrm{H}^{2}$ e da diminuição de $\hat{p}$ fez com que a eficiência da seleção assistida por marcadores, no primeiro ciclo, fosse de 1,427 , o que é um valor menor do aquele encontrado utilizando progênies $S_{1}$, de 1,735 (Tabela 23). Isso corrobora o que foi enfatizado por Lande (1992), de que pouca vantagem existe na seleção assistida por marcadores, ao se utilizar progênies altamente endogâmicas. No entanto, causa surpresa a eficiência observada no ciclo 2, de 1,118 (Tabela 27), 
tendo inclusive os ganhos utilizando e não utilizando marcadores sido estatisticamente diferentes, conforme observa-se nesta mesma Tabela. Confrontando esse resultado com o do ciclo 2 da Tabela 23, isso não era esperado, pois a $\mathrm{H}^{2}$ do ciclo anterior foi menor, e $\hat{\mathrm{p}}$ foi maior, ao se utilizar progênies $S_{1}$.

A comparação entre os dados das Tabelas 25 e 28 pode ajudar a esclarecer as razões dessa diferença de eficiência. Uma vez que progênies $S_{3}$ são mais endogâmicas que progênies $S_{1}$, poder-se-ia pensar que, quando aquelas são usadas como unidades de seleção, haveria a geração de um maior grau de desequilíbrio de ligação no processo de recombinação. No entanto, ao comparar os desequilibrios nas Tabelas 25 e 28, nota-se que o da primeira é na realidade ligeiramente superior. Portanto, este aspecto não deve ter desempenhado importância considerável. Quando se observa as eficiências esperadas em ambos os sistemas, nota-se que as diferenças entre estas e as observadas são menores ao se utilizar o sistema avançado de obtenção de progênies. Assim, é razoável concluir que, embora a eficiência esperada tenha sido menor no ciclo 2 , ao se utilizar progênies $S_{3}$, a maior precisão relativa nesse caso deve ter feito com que os componentes de variância tenham sido estimados com maior precisão, garantindo por sua vez uma melhor estimação de $b_{M}$, ou seja, o coeficiente associado ao escore molecular no índice de seleção. Isso deve ter ocasionado uma maior aproximação entre as eficiências esperadas e observadas.

Apesar da eficiência observada também no ciclo 2, não é prudente concluir que o uso de progênies $S_{3}$ é vantajoso por mais de um ciclo seletivo, quando usado em associação com marcadores moleculares, pois o valor dessa eficiência, 1,118, foi muito baixa, mesmo sendo a significativa a diferença entre os ganhos realizados com a seleção fenotípica e a assistida por marcadores (Tabela 27). Além disso, do ciclo 3 em diante as eficiências foram mais baixas ainda. Essa tendência pode ser também visualizada na Figura 13, 
na qual se observa que do ciclo 2 em diante as taxas de acréscimo foram semelhantes, considerando a seleção assistida por marcadores e a fenotípica.

A perda de eficiência em ciclos subsequentes, ao se utilizar progênies $S_{3}$ como unidades de seleção, deve ter tido a mesma causa dos casos anteriores, ou seja, a diminuição no nível de desequilibrio de ligação, conforme observado na Tabela 28. Isso pôde ser visto igualmente nas reduções ocorridas com as correlações entre o escore molecular e o valor genotípico, ao longo dos ciclos, sempre menores que as raízes quadradas das herdabilidades ao nivel de médias de progênies, observadas na seleção fenotípica.

$\mathrm{Na}$ Tabela 28 ainda pode ser visto que cerca de apenas $3 \%$ dos QTL's apresentaram locos com alelos desfavoráveis fixados, e $4 \%$ com alelos favoráveis, sugerindo que niveis elevados de variabilidade ainda estavam presentes no ciclo 6 , e que ganhos com a seleção ainda poderiam ser conseguidos em ciclos posteriores. O número de locos marcadores com fixação de alelos também foi ligeiramente superior, ao cabo de 6 ciclos seletivos, da ordem de $15 \%$ (Tabela 28 ).

\subsubsection{Efeito do Tamanho da População na Eficiência da SAM}

Os resultados referentes à simulação da seleção assistida por marcadores, variando o número de progênies avaliadas em cada cruzamento ou subpopulação (300 e 160), estão apresentados nas Tabelas 29 a 32, bem como nas Figuras 14 e 15. Nestas situações, admitiu-se $h^{2}=0,025$, efeitos aditivos somente, uma proporção de $5 \%$ de progênies selecionadas, e sistema precoce de obtenção de progênies. Portanto, os resultados obtidos podem ser comparados com aqueles das Tabelas 23 e 25, que se referem às 
mesmas condições, com a diferença de que o número de progênies avaliadas por cruzamento foi igual a 400 . Uma vez que as populações de cada ciclo foram constituídas por 5 cruzamentos ou subpopulações, então o estudo do efeito do número de progênies por cruzamento refere-se, em última instância, ao efeito do tamanho da população sob seleção assistida por marcadores.

Ao se comparar os resultados das Tabelas 23, 29 e 30, uma diferença marcante se refere às eficiências observadas da seleção assistida por marcadores, com relação ao primeiro ciclo seletivo. Com números de progênies iguais a 400, 300 e 160, observa-se que essa eficiência assumiu valores de $1,735,1,656$ e 1,307, respectivamente, em uma nítida tendência de queda. Este resultado esteve de acordo com aqueles de Gimelfarb \& Lande (1994a), que verificaram substanciais melhorias de eficiência, à medida que o tamanho da população aumentou, assumindo os valores de 100, 200, 500, 1000 e 3000 . Face a esses resultados, os autores comentaram que o tamanho da população pode ser tido como o mais importante fator afetando a eficiência da seleção assistida por marcadores. Este aspecto foi novamente verificado por Gimelfarb \& Lande.(1994b).

Conforme discutido no item 2.1, Fouilloux \& Bannerot (1984) mostraram não haver muita vantagem na avaliação de um número muito elevado de linhagens por cruzamento (mais do que algumas dezenas), tanto nos sistemas convencionais de melhoramento de plantas autógamas, como na seleção recorrente. Considerando progênies com grau de endogamia intermediário (ao invés de linhagens puras), não é claro até que ponto este resultado pode ser generalizado. Se igualmente não se justificar a avaliação de (diga-se) centenas de progênies, então isso pode implicar em uma contraindicação bastante relevante quanto ao uso de marcadores na seleção recorrente, face às evidências acerca da importância do tamanho da população na SAM (observadas nesse estudo, bem como por Gimelfarb \& Lande, 1994a,b). Neste estudo foram utilizados tamanhos de populações conjsideráveis, 
de 900 a 2000, tanto para a seleção assistida por marcadores, como para a seleção fenotípica, para que fosse estabelecida igualdade de condições. Admitindo que a seleção convencional não demande um número de progênies assim tão elevado, torna-se evidente que a seleção assistida por marcadores exige um acréscimo substancial de recursos, além daquele oriundo da marcação molecular em laboratório. Este fator pode se constituir em importante limitação ao uso da técnica. Se os gastos envolvidos irão se justificar ou não, pelos maiores ganhos com a seleção, isso é algo que deve ser cuidadosamente avaliado em programas de melhoramento de plantas autógamas, no tocante a características de natureza quantitativa.

Tanto considerando 300 como 160 progênies avaliadas por cruzamento, observa-se uma nítida tendência de queda de eficiência após o primeiro ciclo seletivo (Tabelas 29 e 30). Este aspecto também pôde ser visualizado nas Figuras 14 e 15. Comparando-as, nota-se também o quão pouco a seleção fenotípica é afetada pelo tamanho da população. Em ambos os casos, após 6 ciclos seletivos, o valor genotípico alcançado foi muito semelhante, respectivamente iguais a $57,3 \%$ e $57,0 \%$ do maior valor genotípico possivel (Figuras 14 e 15). Este aspecto foi coerente com os apontamentos de Fouilloux \& Bannerot (1984).

A perda de eficiência ao longo dos ciclos também aqui deve ter ocorrido em função da diminuição do desequilíbrio de ligação a partir do ciclo 1 (Tabelas 31 e 32). Isso refletiu-se também na menor correlação entre o escore molecular e o valor genotípico, menor que a raiz quadrada da herdabilidade, após o ciclo 1. É interessante notar que, com 160 progênies por cruzamento (Tabela 32), houve uma tendência do desequilíbrio de ligação mostrar-se maior a partir do ciclo 2, em relação ao uso de 300 progênies (Tabela 31). Provavelmente, este fato deve estar associado à ocorrência de maior deriva genética, em virtude dos menores tamanhos de subpopulações. Sabe-se que a deriva é um fator importante afetando a ocorrência de desequilíbrio de ligação 
(Lande \& Thompson, 1990; Ruiz \& Barbadilla, 1995). Deve-se observar que, para manter a mesma proporção de progênies selecionadas (5\%) nas populações de diferentes tamanhos, foi preciso igualmente diminuir o número absoluto de progênies selecionadas e utilizadas para compor os ciclos seguintes, o que pode ter contribuído para o aumento de deriva genética.

Ainda comparando as Tabelas 31 e 32, observa-se uma proporção maior de locos com alelos fixados, tanto para os QTL's como para os locos marcadores, na situação em que a população foi menor. Isso também foi coerente com a possibilidade de maior deriva genética.

\subsubsection{SAM em Presença de Dominância Completa}

A avaliação da seleção assistida por marcadores, considerando herdabilidade entre plantas $S_{0}$, no sentido amplo, igual a $5 \%$, presença de dominância positiva completa, sistema precoce de obtenção de progênies, e proporção de progênies selecionadas igual a 5\%, está apresentada nas Tabelas 33 e 34 . Observa-se na Tabela 33 que a eficiência da técnica, em relação à seleção fenotípica, foi notadamente alta no primeiro ciclo seletivo $(2,139)$, declinando consideravelmente nos ciclos seguintes, tendo assumido valores abaixo de 0,90 . Os ganhos com a seleção, utilizando e não utilizando marcadores, foram estatisticamente diferentes, nos ciclos 1 e 4 . Neste último, a seleção baseada na média fenotípica de progênies foi significativamente superior. A Figura 16 ilustra o melhoramento ocorrido com as populações simuladas, sob os dois sistemas, podendo-se observar que, embora havendo uma notável diferença no ciclo 1 , no ciclo 6 a média genotípica das populações sob seleção fenotípica praticamente alcançou a das populações utilizando marcadores. 
Uma vez que o sistema de seleção recorrente aqui utilizado não foi tal que permitisse a obtenção de estimativas da variância aditiva, as herdabilidades no sentido restrito não puderam ser calculadas, nem tampouco as eficiências esperadas. Contudo, é possivel obter aproximações para estas, no primeiro ciclo seletivo, utilizando os valores apresentados no Tabela 13. A partir desta, tem-se que a diferença média entre as variâncias total e aditiva foi igual a $16,42-10,38=6,04$, sendo este portanto o valor médio da variância de dominância. No ciclo 0 , as gerações $S_{0}$ e $S_{1}$ correspondem a gerações $F_{2}$ e $F_{3}$, respectivamente. Além disso, as variâncias aditiva e de dominância, entre médias de progênies $F_{3}$ são respectivamente, iguais a $100 \%$ e $25 \%$ daquelas correspondentes na geração $F_{2}$. Assim, a herdabilidade no sentido restrito, ao nivel de médias de progênies, pode ser aproximadamente obtida, multiplicando $H^{2}$ (Tabela 33) por $10,38 /(10,38+0,25 \times 6,04)=0,873$, obtendo-se um valor de 0,15237 . Por outro lado, a proporção da variância genética explicada por marcadores pode ser obtida tomando-se o valor médio de $\hat{\mathrm{p}}$ do ciclo 0 (Tabela 33), e multiplicando-o pelo inverso do fator acima, fornecendo o valor de 0,923. Com isso, é possivel calcular a eficiência esperada (aproximada) com o uso da seleção assistida por marcadores no ciclo 0 , a qual foi igual a 2,463. Assim, pode-se dizer que houve uma concordância bastante razoável entre as eficiências esperada e observada, apesar do coeficiente $b_{M}$ ter sido sempre calculado utilizando estimativas da variância de dominância ao invés da aditiva.

Em uma situação real, seria igualmente difícil obter estimativas da variância aditiva, principalmente a partir do ciclo 1, quando então as populações se encontram com frequências alélicas diferentes de 0,5. Contudo, os resultados de simulação aqui encontrados sugerem que o índice de seleção de Lande \& Thompson (1990) pode ser utilizado apesar do viés na estimação de $b_{M}$, ao menos em um primeiro ciclo seletivo.

A proporção da variância genética explicada por marcadores foi sempre maior que 0,7 , e o número de locos marcadores com coeficientes de 
regressão estatisticamente significativos foi maior que 30 em 4 dos 7 ciclos considerados (Tabela 33). Apesar disso, a partir do ciclo 1, a correlação entre o escore molecular e o valor genotípico foi sempre menor que a raiz quadrada da herdabilidade, nas populações onde se praticou seleção fenotípica (Tabela 34). Além disso, observa-se nesta mesma Tabela que o desequilibrio de ligação foi drasticamente reduzido, do ciclo $1 \mathrm{em}$ diante. Este fator, aliado à falta de estimativas de variância aditiva, devem ter sido responsáveis pela redução de eficiência após esse ciclo. Pode-se ainda observar que, após 6 ciclos seletivos, a proporção de QTL's com alelos fixados ainda foi pequena, e o número de locos marcadores polimórficos elevado, indicando uma baixa ocorrência de deriva genética.

No primeiro ciclo seletivo, a presença de dominância fez com que a seleção assistida por marcadores fosse mais eficiente, em relação à eficiência observada com efeitos aditivos somente, com o mesmo valor de herdabilidade (Tabela 18). Contudo, deve-se salientar que as populações de referência eram gerações $S_{0}$, nas quais o efeito de dominância positiva completa faz com que o valor genotípico médio seja aumentado, em relação aos casos de ausência de dominância. Assim, essa maior eficiência não implica necessariamente em uma maior probabilidade de extração de linhagens endogâmicas superiores.

\subsubsection{Efeito da Proporção de Progênies Selecionadas na SAM}

As Tabelas 35, 36, 37 e 38 apresentam resultadios referentes à simulação da seleção assistida por marcadores, com herdabilidade inicial entre plantas $S_{0}$ igual a 0,025, ausência de dominância, sistema precoce de obtenção de progênies, e proporções de progênies selecionadas iguais a 
$10 \%, 2,5 \%, 1 \%$ e $0,25 \%$, respectivamente. Estas proporções corresponderam à seleção de um número absoluto de progênies igual a 40,10, 4 e 1, em cada subpopulação ou cruzamento com um total de 400 avaliadas.

Conforme observa-se nas Tabelas 35 a 38 , um ponto em comum em todas as situações foi a da perda considerável de eficiência após o primeiro ciclo seletivo. Somente houve diferença significativa entre os ganhos com a seleção, utilizando e não utilizando marcadores, no ciclo 1 , em todas as situações. Contudo, levando em conta apenas este ciclo seletivo, nota-se uma tendência de queda nesses parâmetros, ao se diminuir a proporção de progênies selecionadas. As eficiências relativas foram iguais a 1,871, 1,637, 1,564 e 1,304, para as proporções $10 \%, 2,5 \%, 1 \%$ e $0,25 \%$, respectivamente. Uma razão plausível para esse comportamento é a piora crescente na qualidade da amostragem das progênies superiores. $O$ número absoluto de progênies selecionadas reduziu de 40, na maior proporção, para 1, na menor. É assim razoável supor que a identificação de progênies superiores tornou-se mais difícil, à medida que o tamanho da amostra diminuiu. Por exemplo, ao se tomar poucas progênies de melhor desempenho (10 ou menos) foi comum a ocorrência de empates quanto ao valor do escore molecular (dados não apresentados). Assim, tais progênies eram tidas como iguais, do ponto de vista da informação molecular, mesmo que fossem recombinantes. Quando o tamanho da amostra é maior, contudo, ocorre um número maior de valores de escore molecular, diluindo esse efeito da recombinação, e eventualmente aumentando a eficiência da seleção assistida por marcadores. Gimelfarb \& Lande (1994a), trabalhando com uma população simulada de 1000 indivíduos e 6 marcadores compondo o escore molecular, também observaram reduções de eficiência ao diminuir a proporção de indivíduos selecionados de $25 \%$ para $10 \%$.

As Figuras 17 a 20 ilustram o melhoramento ocorrido nas populações sob seleção fenotípica e assistida por marcadores, nas diversas proporções de progênies selecionadas por ciclo. À medida que estas 
diminuíram, nota-se um aumento na inclinação das curvas, que é um reflexo do maior diferencial de seleção. A partir do ciclo 1 , nota-se em todos os casos um forte paralelismo entre as curvas relativas às populações nas quais se utilizou e não se utilizou informação molecular.

Ao se comparar as Tabelas 35 a 38, também é interessante notar como, à medida que a proporção de progênies selecionadas diminui, também diminuem a herdabilidade, o número de locos marcadores significativos, a proporção da variância genética explicada por marcadores e o coeficiente de determinação em ciclos avançados (após o ciclo 3, por exemplo). Certamente, isso foi um reflexo da perda de variabilidade, tanto em QTL's como nos locos marcadores, resultante da diminuição no número absoluto de progênies selecionadas em cada ciclo.

Os resultados apresentados nas Tabelas 39, 40, 41 e 42 ilustram alguns aspectos relevantes, no que se refere a consequências da variação da proporção de progênies selecionadas. Comparando seus valores, para um mesmo dado ciclo seletivo (que não o ciclo 1), nota-se uma tendência de aumento do desequilíbrio de ligação ao se diminuir aquela proporção. Por exemplo, o desequilíbrio aumentou de 0,022 (13,8\% do valor de referência em $\mathrm{C}_{0}$ ), no ciclo 2, para 0,056 (35,0\% do valor de referência), ao se diminuir de 40 para 1 o número de progênies selecionadas por cruzamento. Isso reflete o fato de se utilizar, como unidade de recombinação, descendentes de apenas 1 progênie endogâmica, diminuindo o problema da mistura de fases de ligação.

Por outro lado, comparando as Tabelas 39, 40, 41 e 42, nota-se que, à medida que o número absoluto de progênies selecionadas diminuiu, aumentou-se a proporção de locos com alelos fixados, tanto no que se refere aos marcadores como aos QTL's. No ciclo 6, utilizando a maior proporção de progênies selecionadas, não ocorreu a fixação de QTL's, e apenas $1,2 \%$ dos locos marcadores apresentaram alelos fixados, em média (Tabela 39). Quando a menor proporção de progênies selecionadas foi utilizada (Tabela 42), 63,1\% 
dos QTL's apresentaram alelos fixados, sendo que desses, $36,9 \%$ corresponderam a locos com alelos desfavoráveis, também no ciclo 6 . A proporção de locos marcadores apresentando fixação foi muito alta, igual a $71,5 \%$ em média, no mesmo ciclo. Certamente, essa redução crescente no polimorfismo, ao longo dos ciclos seletivos, deve ter contribuído para que a eficiência da seleção assistida por marcadores moleculares se reduzisse. Observa-se, por exemplo, que a correlação entre o escore molecular e o valor genotípico mostrou uma tendência de aumento no primeiro ciclo, ao diminuir a proporção de progênies selecionadas, mas uma tendência oposta pode ser vista no tocante ao ciclo 6 . Enquanto que essa correlação foi igual 0,422 ao se selecionar $10 \%$ das progênies em cada cruzamento (Tabela 39 ), este valor caiu para 0,289 , ao se utilizar a menor proporção de progênies selecionadas (Tabela 42).

Os aspectos apontados acima refletem uma notável dificuldade para que se obtenha eficiência com 0 uso de marcadores moleculares na seleção recorrente. Pode-se dizer que, para que se aumente o desequilíbrio de ligação, ao longo dos ciclos seletivos, há que se promover a seleção de um número absoluto reduzido de indivíduos ou progênies. No entanto, esse fato, aliado à necessidade de a população ser de tamanho elevado, conforme discutido no item anterior, faz com que a intensidade de seleção seja alta. A consequência disso é a redução da variabilidade, pela fixação de alelos tanto em QTL's como em locos marcadores, limitando o ganho com a seleção por mais de uns poucos ciclos seletivos. Assim, utilizando uma população-base formada com mais de duas linhagens endogâmicas, parece difícil que a seleção assistida por marcadores seja compensatória por mais de um ciclo seletivo,.

As Tabelas 43 e 44 apresentam resultados adicionais referentes à seleção assistida por marcadores utilizando uma proporção reduzida de progênies selecionadas $(0,25 \%)$, em presença de dominância 
positiva completa, herdabilidade inicial no sentido amplo, ao nivel de plantas $S_{0}$, igual a 0,05 , e sistema precoce de obtenção de progênies. Em relação à utilização de uma proporção de progênies selecionadas igual a 5\% (Tabela 33), observou-se aqui uma redução de eficiência no ciclo 1, passando de 2,139 para 1,888 (Tabela 43). As causas para tanto também devem estar relacionadas à menor qualidade da amostragem das progênies superiores, com base na informação molecular. Mesmo com os maiores valores de desequilíbrio de ligação, a partir do ciclo 1 (Tabela 44), não ocorreu uma eficiência relevante da seleção assistida por marcadores, à exceção do ciclo 5 , sendo $20 \%$ superior à seleção fenotípica. No entanto, a diferença observada entre os ganhos sob os dois sistemas não foram estatisticamente significativos.

De uma maneira geral, o que deve ter ocorrido é que os problemas de amostragem devem ter se somado ao fato de não se dispor de estimativas da variância aditiva, para estimar o coeficiente $b_{M}$. Pode-se observar na Tabela 44 que a correlação entre o escore molecular e o valor genotípico associados às progênies esteve sempre próxima à raiz quadrada das herdabilidades, a partir do ciclo 1. Além disso, ao cabo de 6 ciclos seletivos, a fixação tanto em QTL's como em locos marcadores foi bastante elevada, em média $(68,3 \%$ e $75,1 \%$, respectivamente).

A Figura 21 ilustra o aumento no valor genotípico médio das populações nas quais se utilizou e não se utilizou informação molecular. Podese observar que, apesar das perdas de eficiência ocorridas nos ciclos 2, 3 e 4, o valor genotípico médio das populações que sofreram seleção assistida por marcadores foi marcadamente superior ao daquelas nas quais se praticou seleção fenotípica. Novamente deve-se salientar que os efeitos de dominância presentes nas populações de referência $S_{0}$ são expressivos, e assim não há necessariamente uma maior probabilidade de obtenção de linhagens endogâmicas superiores. 
Nas Tabelas 45 e 46 estão apresentados resultados referentes à simulação da seleção assistida por marcadores, também com uma proporção de progênies selecionadas igual a 0,25\%, mas utilizando o sistema avançado de obtenção de progênies, e em presença de efeitos aditivos somente. Observa-se na Tabela 45 que, considerando apenas o primeiro ciclo seletivo, a eficiência da utilização de marcadores foi aumentada com a diminuição do número de progênies selecionadas, passando de 1,427 (Tabela 27) para 1,540. Além disso, é interessante notar na Tabela 45 a tendência de manutenção dessa eficiência também no segundo ciclo seletivo. Isso deve ter decorrido do maior valor para o desequilíbrio de ligação no ciclo 1 , em consequência de se selecionar apenas uma progênie em cada cruzamento, e em maior nivel de homozigose, uma vez que corresponderam a progênies $S_{3}$. De fato, conforme observa-se na Tabela 46, o desequilíbrio de ligação foi, em média, igual a 0,087 , um valor maior do aquele obtido utilizando-se $5 \%$ de progênies selecionadas (Tabela 28). Conforme se observa na Tabela 45, causa surpresa o fato de a eficiência realizada ter sido maior que a esperada, no ciclo 2. Contudo, trata-se de um resultado isolado, único em todo esse estudo, refletindo a baixa probabilidade com que esse fenômeno é esperado.

Após 6 ciclos seletivos, as populações nas quais se simulou seleção assistida por marcadores apresentaram um valor genotípico médio consideravelmente maior do aquelas sob seleção fenotípica, conforme observase na Figura 22, ainda que do ciclo $3 \mathrm{em}$ diante as diferenças entre as curvas tenham sido praticamente constantes. Nota-se que, no sexto ciclo seletivo, as populações sob seleção assistida por marcadores atingiram um valor genotípco médio de quase $80 \%$ do valor máximo.

Após o ciclo 2, a eficiência próxima de 1 deve ter sido um reflexo da alta fixação quanto aos locos marcadores (Tabela 46), chegando a $86,6 \%$ no ciclo 6 . Essa redução no polimorfismo também pode ser ocasionado as reduções dos valores de $\hat{p}$ (Tabela 45), e na correlação entre os escores 
moleculares e os valores genotípicos associados às progênies. Estes resultados reforçam o aspecto já comentado de que, se por um lado a diminuição no número de progênies selecionadas aumenta o desequilíbrio de ligação, por outro reduz a variabilidade e o nivel de polimorfismo. Nota-se que, no ciclo $6,86,0 \%$ dos QTL's apresentaram, em média, alelos fixados, sendo que, desses, $38,0 \%$ eram referentes a alelos desfavoráveis.

Alguns procedimentos pelos quais se poderia diminuir essa redução tanto no polimorfismo como na variabilidade, seriam a utilização de mapas moleculares ainda mais saturados do que o apresentado até aqui, e o uso de maiores tamanhos efetivos. Esses fatores serão discutidos, respectivamente, nos itens 4.2 .8 e 4.2.9.

\subsubsection{Efeito da Heterogeneidade do Solo na SAM}

Em relação a estudos preliminares envolvendo a simulação de seleção assistida por marcadores (Zhang \& Smith, 1992; Edwards \& Page, 1994, Gimelfarb \& Lande, 1994a,b; Ferreira, 1995), este trabalho considerou 2 fatores adicionais: o uso de mais de 2 linhagens endogâmicas para formar a população-base, e unidades de seleção correspondentes a progênies, avaliadas em delineamentos experimentais, ao invés de indivíduos (seleção massal). Esta é uma situação frequente na seleção recorrente de plantas autógamas (Tabela 5), possivelmente em virtude da dificuldade da avaliação de plantas individuais, no tocante a características como produtividade de grãos.

Com relação aos aspectos de experimentação, optou-se, até aqui, pela consideração de um solo de heterogeneidade média, fixando um valor para o coeficiente b de Smith (1938) de 0,5. Considerando-se uma 
herdabilidade ao nível de plantas $\mathrm{S}_{0}$ como fixa, é evidente que aquela ao nivel de médias de progênies irá variar, conforme o número de repetições, e conforme a heterogeneidade do solo. Quanto menor for o valor de b, maior será a importância do componente de variância associado ao erro experimental (ou seja, à variação entre parcelas) na composição da variação ambiental e fenotípica. Dessa forma, a herdabilidade ao nível de médias de progênies é relativamente menor em um solo com b menor, para um valor fixo da variância não-genética total. $E$, naturalmente, isso deve alterar a eficiência da seleção assistida por marcadores.

Para melhor avaliar o impacto de diferentes níveis de heterogeneidade do solo nessa eficiência, foram simulados solos com o coeficiente de Smith (1938) igual a 0,2 e a 0,8, cujos resultados podem ser visualizados nas Tabelas 47, 48, 49 e 50. Nestes casos, foi considerada uma herdabilidade inicial entre plantas $S_{0}$ igual a 0,025 , efeitos aditivos somente, sistema precoce de obtenção de progênies, e proporção de progênies selecionadas igual a $0,25 \%$.

Conforme a Tabela 47, observa-se que a herdabilidade ao nível de médias de progênies, no ciclo 0 , com $b=0,2$, foi igual a 0,076 , um valor consideravelmente menor do aquele correspondente da Tabela 38, sob as mesmas condições, mas com $b=0,5$. Observa-se que isso ocasionou uma eficiência no primeiro ciclo seletivo igual a 1,596, um valor superior ao correspondente da Tabela 38, igual a 1,304. A partir do ciclo 2, houve uma redução drástica nos valores de eficiência da seleção assistida por marcadores (Tabela 47), da mesma forma como observado com $b=0,5$. Isso pode igualmente ser visto na Figura 23, na qual se vê curvas praticamente paralelas a partir do ciclo 2. A julgar pelos valores de desequilibrio listados na Tabela 48, este fator também aqui deve ter sido o responsável por esta perda de eficiência. A correlação entre o escore molecular e o valor genotípico também diminuiu a 
partir do ciclo 2, embora tendo se mantido superior à raiz quadrada da herdabilidade nas populações nas quais se praticou seleção fenotípica.

As Tabelas 49 e 50 se referem aos resultados da simulação de seleção assistida por marcadores, com $b=0,8$. Nota-se na Tabela 49 que sua eficiência, no primeiro ciclo seletivo, foi igual a 1,527 , a qual não foi muito menor do aquele correspondente, com $b=0,2$ (Tabela 47). Embora tendo ocorrido um aumento considerável na herdabilidade ao nível de médias de progênies (igual a 0,214), o que diminuiria a eficiência da seleção assistida por marcadores, a proporção da variância genética explicada por marcadores foi superior $(0,837)$, possivelmente em detrimento do maior poder do teste, resultante da maior precisão média dos experimentos. Isso deve ter compensado em parte as perdas de eficiência devido ao aumento na herdabilidade.

Com $b=0,2$, no segundo ciclo seletivo a diferença entre os ganhos sob os dois sistemas não foi significativamente diferente de zero, enquanto que com $b=0,8$ esse fato ocorreu. Isso causa surpresa, uma vez que no ciclo anterior, a herdabilidade foi menor e a proporção da variância genética explicada por marcadores foi maior com $b=0,2$. Na Figura 24 nota-se uma diferença média maior entre as curvas, quando comparada com a Figura 23. No entanto, com o menor valor de $b$, as diferenças entre as eficiências observadas e as realizadas foram maiores. Provavelmente, isso deve ter decorrido do aumento na precisão, quando do aumento em b. Assim, é importante salientar que aumentos no coeficiente de heterogeneidade do solo não implicam necessariamente em diminuições na eficiência da seleção assistida por marcadores, devido ao aumento correspondente da herdabilidade ao nível de médias de progênies; antes, a julgar por estes resultados, o aumento na precisão pode afetar sensivelmente essa eficiência no sentido de aumentá-la, aproximando-se daquela esperada se os parâmetros fossem conhecidos. 
Comparando os resultados das Tabelas 48 e 50, nota-se que a correlação entre o escore molecular e o valor genotípico foi maior com $b=$ 0,8, o que reforça o aspecto de o aumento de precisão ter aumento o poder do teste na detecção de marcas ligadas a QTL's. A raiz quadrada da herdabilidade foi maior também com $b=0,8$, em consequência da diminuição da variação fenotípica. Em relação aos outros parâmetros dessas Tabelas, não houve diferenças notáveis considerando as duas situações.

Estes resultados em conjunto demonstram a importância das condições de experimentação na maior ou menor eficiência da seleção assistida por marcadores. Nesse sentido, é interessante a realização de estudos preliminares, para a estimação do coeficiente de heterogeneidade de solo de Smith (1938). Isso pode ser feito através de uso de ensaios de uniformidade, com a simulação de diferentes tamanhos de parcela, hierarquizados entre si, e com o uso do método dos quadrados mínimos generalizado (Cordeiro et al., 1990; Bearzoti \& Pinto, 1993).

\subsubsection{Efeito do Número de Marcadores na SAM}

No item 4.2.6 comentou-se que, embora o uso de um número pequeno de progênies selecionadas por cruzamento possa aumentar 0 desequilíbrio de ligação, isso provoca uma maior proporção de locos marcadores e de QTL's com alelos fixados, provocando uma redução tanto no número de marcas polimórficas, como na variabilidade. Uma forma de diminuir o impacto no polimorfismo seria a de utilizar mapas moleculares mais saturados do que os usados até aqui, caso sejam disponiveis. Para testar essa hipótese, simulou-se um genoma igual ao da Figura 1 com relação aos QTL's, mas com um número de 200 marcadores com disposição sistemática, ou seja, com 18 
marcas igualmente espaçadas $(5,88 \mathrm{cM})$ por cromossomo. Trata-se de uma situação ótima, podendo este mapa ser considerado bastante saturado.

Os resultados referentes à simulação da seleção assistida por marcadores, utilizando este mapa, e considerando uma herdabilidade inicial ao nível de plantas $S_{0}$ igual a 0,025 , efeitos aditivos somente, sistema precoce de obtenção de progênies, e com a seleção de uma única progênie por cruzamento, estão apresentados nas Tabelas 51 e 52. Comparando-se a Tabela 51 com a Tabela 38, nota-se que o uso de 200 locos marcadores, ao invés de 130 , provocou aumentos no número de coeficientes de regressão estatisticamente significativos, na proporção da variância genética explicada por marcadores, no coeficiente de determinação, na maioria dos ciclos seletivos. No primeiro ciclo, a eficiência realizada foi maior sob 200 marcadores. Entretanto, da mesma forma que na Tabela 38, a partir do segundo ciclo a eficiência caiu bastante, tendo no segundo ciclo sido bastante semelhantes $(1,121$ e 1,122$)$; os ganhos médios com a seleção utilizando e não utilizando marcadores também só foram estatisticamente diferentes no primeiro ciclo. Comparando as Figuras 20 e 25, nota-se uma maior diferença nesta última, entre as curvas referentes ao aumento nas médias das populações melhoradas, simulando seleção fenotípica e assistida por marcadores.

Comparando as Tabelas 52 e 42, nota-se que os desequilíbrios de ligação foram semelhantes, para um mesmo ciclo, bem como a proporção de QTL's e locos marcadores com alelos fixados, e a raiz quadrada das herdabilidades. A correlação entre o escore molecular e o valor genotípico aumentou com o uso de 200 marcadores, mas aparentemente este aumento não propiciou aumentos consideráveis da eficiência da seleção assistida por marcadores.

Também foi utilizado um mapa com 30 marcadores, sistematicamente dispostos no genoma. Os resultados da simulação da seleção assistida por marcadores, utilizando esse mapa, e nas mesmas condições da 
situação anterior, estão apresentados nas Tabelas 53 e 54 . Nota-se, na primeira destas Tabelas, que o uso de 30 marcadores levou a uma eficiência muito baixa, em todos os ciclos seletivos, inclusive o primeiro. Isso contrasta com todos os resultados de situações apresentadas anteriormente, considerando 130 locos marcadores. Na Figura 26 , as curvas referentes à utilização e não utilização de marcadores são quase coincidentes.

Conforme apontado no Capítulo 'Metodologia', na formação da população-base cuidou-se em guardar um nível de dissimilaridade genética igual a 0,40 , conforme expressão em (3.4). Utilizando 30 marcadores, isso equivaleu à ocorrência de 12 deles apresentando polimorfismo, em cada cruzamento da população base do ciclo 0 . Este é um valor inferior ao mínimo sugerido por Lande \& Thompson (1990), na primeira geração após a hibridação (Tabela 7), evidenciando a necessidade de que haja um número satisfatório de marcas polimórficas para que estas sejam de alguma valia para fins de seleção recorrente. É marcante na Tabela 53 os baixos valores da proporção da variância genética explicada por marcadores, e do coeficiente de determinação, em relação ao conjunto das situações consideradas anteriormente, com 130 locos marcadores.

Considerando a presença de apenas 30 locos marcadores, não foi possível obter estimativas do desequilíbrio de ligação, mas não há razões para crer que este parâmetro tenha sido muito diferente, em relação às situações anteriores semelhantes, considerando 130 ou 200 marcas. A proporção de QTL's e locos marcadores com alelos fixados foi também semelhante (comparando, por exemplo, as Tabelas 54 e 52), sendo que a proporção de alelos desfavoráveis foi ligeiramente superior com a utilização de 30 marcas.

Observa-se na Tabela 54 que a correlação entre o escore molecular e o valor genotípico foi sempre muito próximo ou mais baixo que a raiz quadrada da herdabilidade, refletindo também o número insuficiente de 
marcas polimórficas, e possivelmente também a diminuição do desequilíbrio de ligação a partir do ciclo 1 , embora não tivesse sido possível estimar essa grandeza, nesse caso.

\subsubsection{Efeito do Tamanho Efetivo na SAM}

A utilização de uma baixa proporção de progênies selecionadas provocou uma redução de variabilidade na característica quantitativa simulada e no número de marcas polimórficas, conforme observado no item 4.2.6. Foi sugerido que uma maneira de diminuir esse problema seria a utilização de um mapa molecular mais saturado e/ou um tamanho efetivo maior. Para verificar a eficiência do uso do segundo fator, foi simulada a construção de uma população-base a partir de 20 linhagens, guardando o mesmo nível de dissimilaridade genética das situações anteriores, entre as linhagens. Além disso, admitiu-se um solo com coeficiente de heterogeneidade igual a 0,2 , que, conforme observado no item 4.2.7, pode levar a valores maiores de eficiência da seleção assistida por marcadores. Os resultados dessa simulação, considerando a herdabilidade inicial entre plantas $S_{0}$ igual a 0,025 , efeitos aditivos somente, sistema precoce de obtenção de progênies, e uma proporção de progênies selecionadas igual a 0,25\%, estão apresentados nas Tabelas 55 e 56.

Segundo a Tabela 55, a seleção assistida por marcadores apresentou valores satisfatórios de eficiência apenas no primeiro ciclo seletivo, após o qual ela foi reduzida a valores próximos de 1 . Trata-se de um resultado que causa surpresa, levando em conta os baixos valores de herdabilidade e os as altas proporções da variância genética explicada por marcadores (Tabela 55). Novamente aqui a redução de precisão (devido ao menor valor de b), deve 
ter provocado uma maior diferença entre as eficiências realizada e esperada, caso os parâmetros fossem conhecidos. Nota-se que esta última foi sempre maior do que 2, tendo sido mesmo maior que 3, no ciclo 1 . A Figura 27 ilustra que o uso ou não de marcadores ocasionou diferenças de eficiência modestas, nas populações de maior tamanho efetivo.

$\mathrm{Na}$ Tabela 56, nota-se que a fixação nos locos marcadores foi menor em ciclos avançados, quando comparada com aquela ocorrida com a utilização de apenas 5 linhagens para compor a população-base, em igualdade de condições (Tabela 48). No entanto, pode-se dizer que mesmo quadruplicando o tamanho efetivo, a fixação nos locos marcadores foi ainda consideravelmente alta, sempre acima de $50 \%$ a partir do segundo ciclo seletivo. As proporções de QTL's fixados, favoráveis e desfavoráveis, guardaram uma semelhança maior, quando comparadas as Tabelas 56 e 48. A correlação entre o escore molecular e o valor genotípico, bem como a raiz quadrada das herdabilidades (Tabela 56) foram semelhantes aos valores correspondentes da Tabela 48, da mesma forma que o desequilíbrio de ligação.

Estes resultados ilustram que mesmo com um substancial gasto de recursos para aumento do tamanho efetivo da população, pela avaliação de 8000 progênies por ciclo, em 2 repetições, não foi possivel obter valores de eficiência para a seleção assistida por marcadores que justificassem o investimento despendido. Há que se observar que uma limitação neste estudo foi 0 fato de se ter mantido constante o número de locos controladores da característica em questão (50). É provável que, em uma situação real, o aumento no número de linhagens para compor a população-base aumente o número de poligenes segregando simultaneamente. Não obstante, não há razões evidentes para afirmar que a eficiência da SAM aumentaria com o aumento no número de QTL's; na realidade, aparentemente espera-se o contrário (Edwards \& Page, 1994). 


\subsubsection{Considerações Finais}

Os resultados observados no presente trabalho, de uma forma geral, não atestam como compensatório o uso de marcadores moleculares na seleção recorrente de plantas autógamas. Isso contrasta, até certo ponto, com estudos anteriores envolvendo simulação de seleção assistida por marcadores (Zhang \& Smith, 1992; Edwards \& Page, 1994; Gimelfarb \& Lande, 1994a,b; Ferreira, 1995). A razão principal dessa diferença é a de que, naqueles trabalhos, sempre se trabalhou com populações-base formadas a partir do cruzamento entre 2 linhagens endogâmicas apenas, ou seja, com tamanho efetivo igual a 1. Isso faz com que as fases de ligação entre QTL's e locos marcadores se mantenham as mesmas ao longo dos vários ciclos seletivos, sendo as perdas de eficiência, em essência, devidas exclusivamente à permuta genética.

Neste estudo, optou-se pela simulação de uma populaçãobase formada com 5 ou 20 linhagens, devido ao fato de os melhoristas de plantas autógamas em geral utilizarem tamanhos efetivos moderados ou elevados (Tabela 5). Isso acarreta um problema do ponto de vista do aproveitamento da informação molecular, pois, no sistema de seleção recorrente empregado, ocorreu uma mistura de fases de ligação no processo de recombinação, com uma consequente diminuição no desequilibrio de ligação. É difícil conceber um sistema contínuo de seleção recorrente onde este fenômeno não ocorra. Aqui tentou-se diminuir esse problema pela seleção de uma única progênie endogâmica por cruzamento. Isto no entanto acarretou uma diminuição tanto na variabilidade como no número de marcas polimórficas, o que prejudicou a eficiência da seleção assistida por marcadores em ciclos subsequentes. Este 
aspecto não pôde ser contornado nem pelo aumento do tamanho efetivo, nem pela maior saturação do mapa molecular.

Quando a seleção é praticada em um único ciclo seletivo, após o cruzamento entre linhagens endogâmicas, então uma maior eficiência em relação à seleção fenotípica foi repetidas vezes observada neste trabalho, em virtude de que, em apenas um ciclo seletivo, não há oportunidade de ocorrência da mistura de fases de ligação, mencionada anteriormente.

Mesmo quando aparentemente vantajosa, contudo, deve ser enfatizado que a maior eficiência da seleção assistida por marcadores se deu apenas com um substancial aumento de custos, relacionados tanto ao processo de marcação molecular em laboratório, como à necessidade de avaliação de um grande número de indivíduos ou progênies, para que o índice de seleção, reunindo informação fenotípica e molecular, possa ser adequadamente empregado. Se o marcador utilizado for de natureza genética dominante, como o AFLP (o qual é aparentemente promissor em plantas autógamas), então custos adicionais de marcação estarão implícitos, pelo uso de testes de progênies para identificação de indivíduos heterozigotos, de maneira a possibilitar exatamente o mesmo sistema de seleção assistida por marcadores utilizado nesse estudo. Estes testes de progênie seriam possiveis de ser realizados no sistema aqui adotado, em virtude de as unidades de seleção terem sido progênies endogâmicas, obtidas por autofecundação de plantas $S_{0}$ ou $S_{2}$.

Fatores que pderiam ser abordados em estudos futuros, e que não foram considerados aqui, são a ocorrência de interação genótipos por ambientes, de epistasia, de níveis diferenciados quanto ao grau de dominância e a ocorrência de alelismo múltiplo. Merece destaque o primeiro fator mencionado, sabidamente uma das maiores limitações no fitomelhoramento. Seria interessante investigar se a seleção assistida por marcadores pode diminuir seu impacto. A julgar pelo estudo de Gimelfarb \& Lande (1994b), a 
interação de genótipos por ambientes atua no sentido de diminuir ainda mais a eficiência da SAM.

Apesar de a seleção assistida por marcadores ter se mostrado pouco promissora em ciclos sucessivos, é importante salientar que a sua eficiência esperada, caso fossem conhecidos os componentes da variância genética da população, é substancial. Assim, no futuro, a técnica pode ainda vir a possuir maior potencial, caso técnicas estatísticas sejam desenvolvidas de maneira a possibilitar o uso de índices de seleção com maior precisão, diminuindo a discrepância existente entre a eficiência esperada e a realizada, e eventualmente com menor demanda quanto ao tamanho da amostra. Este corresponde a um rico campo para pesquisas futuras, e que deveria ser explorado. 


\section{CONCLUSÕES}

a. A seleção recorrente assistida por marcadores, em espécies autógamas, foi pouco eficiente por mais de um ciclo seletivo, quando a população-base é formada por mais do que duas linhagens endogâmicas. Isso em parte foi devido à ocorrência de diferentes fases de ligação entre QTL's e locos marcadores, reduzindo o nivel de desiquilíbrio de ligação.

b. Quando considerada em apenas um ciclo seletivo, a seleção assistida por marcadores foi em geral eficiente, sendo que essa eficiência aumenta à medida que a herdabilidade ao nivel de plantas $S_{0}$ diminui, e consequentemente a herdabilidade ao nivel de progênies $S_{1}$.

c. O tamanho das subpopulações utilizadas, ou seja, o número de progênies avaliadas em cada cruzamento, constituiu-se em importante fator afetando a eficiência da seleção assistida por marcadores no primeiro ciclo seletivo, demandando o uso de algumas centenas de progênies para que uma superioridade mínima seja obtida em relação à seleção fenotípica.

d. A presença de dominância positiva completa não impossibilitou que a seleção assistida por marcadores fosse eficiente no primeiro ciclo seletivo, mesmo 
levando em conta que estimadores tendenciosos dos coeficientes do indice de seleção foram utilizados.

e. Menores proporções de progênies selecionadas prejudicaram a eficiência da seleção assistida por marcadores no primeiro ciclo seletivo.

f. A seleção de uma única progênie por cruzamento, determinando a formação de subpopulações pelo uso de apenas duas progênies, possibilitou o aumento do nivel de desequilíbrio de ligação em ciclos avançados, mas isso não acarretou em um aumento substancial de eficiência da seleção assistida por marcadores. Em parte isso se deveu aos elevados niveis de deriva genética ocorridos nesse caso.

g. Quando o coeficiente de heterogeneidade de Smith é baixo, a eficiência da seleção assistida por marcadores aumentou, devido à diminuição na herdabilidade ao nivel de médias de progênies.

h. O uso de 200 locos marcadores não propiciou aumentos consideráveis de eficiência da seleção assistida por marcadores, em relação ao uso de um total de 130.

i. A composição da população-base a partir de 20 linhagens endogâmicas, ao invés de 5 , não ocasionou um aumento de tamanho efetivo suficiente para evitar o elevado nível de deriva genética ocorrido, quando uma única progênie era selecionada por cruzamento.

j. Quando um número pequeno (da ordem de 10) de progênies é avaliado, tanto o estimador proposto neste estudo, como o coeficiente de determinação foram 
insatisfatórios para estimação da proporção da variância genética explicada por marcadores moleculares, devido a altas tendenciosidades e/ou à baixa precisão.

I. Quando a herdabilidade da característica é alta, ou tanto a herdabilidade como a proporção da variância genética explicada por marcadores são elevadas, o coeficiente de determinação mostrou-se como uma estatística preferivel, em relação ao estimador proposto.

m. Se o número de progênies avaliadas é elevado (algumas centenas), então o estimador proposto mostrou-se mais apropriado, com um nivel de tendenciosidade menor do que o do coeficiente de determinação, e com um grau de precisão tolerável. 


\section{REFERÊNCIAS BIBLIOGRÁFICAS}

APUYA, N.; FRAZIER, B.L.; KEIM, P.; ROTH, E.J. \& LARK, K.G. Restriction lenght polymorphisms as genetic markers in soybean, Glycine max (L.) Merr. Theoretical and Applied Genetics, v.75, p.889-901, 1988.

AKKAYA, M.S.; BHAGWAT, A.A.; CREGAN, P.B. Length plymorphisms of simple sequence repeat DNA in soybean. Genetics, v.32, p.1131-1139, 1992.

AVEY, D.P.; OHM, H.W.; PATTERSON, F.L. \& NYQUIST, W.E. Three cycles of simple recurrent selection for early heading in winter wheat. Crop Science v.22, p.908-912, 1982.

BAILEY, D.W. Recombinant imbred strains. Transplantation, v.11, p.325-327, * 1971.

BAILEY, N.T.J. Introduction to the mathemathical theory of genetic linkage. London: Oxford University Press, 1961. 298p.

BAKER, R.J. Selection indices in plant breeding. Boca Raton: CRC Press, 1986. 139p.

BEARZOTI, E.; PINTO, C.A.B.P. Dimensionamento de parcela em experimentos de seleção em batata (Solanum tuberosum L.). Ciência e Agrotecnologia, v.20, n.2, p.151-159, 1996.

BEAVER, J.S. \& KELLY, J.D. Comparison of selection methods for dry bean populations derived from crosses between gene pools. Crop Science, v.34, p.34-37, 1994. 
BEAVIS, W.D.; GRANT, D.; ALBERTSEN, M. \& FINCHER, R. Quanitative trait loci for plant height in four maize populations and their associations with qualitative genetic loci. Theoretical and Applied Genetics, v.83, p.141145, 1991.

BECKMAN, J.S. \& SOLLER, M. Restriction fragment lenght polymorphisms in plant genetic improvement. In: MIFLIN, B.J. (Ed.) Oxford surveys of plant molecular and cell biology. Oxford, 1986. p.126-250: v.3.

BECKMANN, J.S. \& SOLLER, M. Toward a unified approach to genetic mapping of eukaryotes based on sequence tagged microsatellite sites. Biotechnology, v.8, p.930-932, 1990.

BENNETZEN, J.L. \& MELAKE-BERHAN, A. Generation of a genetic map for Sorghum bicolor. In: PHILLIPS, R.L. \& VASIL, I.K. (Ed.) DNA-based markers in plants. Dordrecht: Kluwer Academic Publishers, 1994. p.291298.

BEST, D. J.; ROBERTS, D. E. Algorithm AS91. The percentage points of the chi-squared distribution. Applied Statistics, v.24, p.385-388, 1975.

BOTSTEIN, D.; WHITE, R.L.; SKOLNICK, M. \& DAVIS, R.W. Construction of a genetic linkage map in man using restriction fragment length polymorphisms. American Journal of Human Genetics, v.32, p.314-331, 1980.

BRIM, C.A. \& BURTON, J.W. Recurrent selection in soybeans. II.Selection for increased percent protein in seeds. Crop Science, v.19, p.494-498, 1979.

BRIM, C.A. \& STUBER, C.W. Application of genetic male sterility to the recurrent selection schemes in soybeans. Crop Science, v.13, p.528-530, 1973.

BURR, B. Some concepts and new methods for molecular mapping in plants. In: PHILLIPS, R.L. \& VASIL, I.K. (Ed.) DNA-based markers in plants. Dordrecht: Kluwer Academic Publishers, 1994. p.1-7. 
BURTON, J.W., KOINANGE, E.M.K. \& BRIM, C.A. Recurrent selfed progeny selection for yield in soybean using genetic male sterility. Crop Science, v.30, p.1222-1226, 1990

BUSCH, R.H. \& KOFOID, K. Recurrent selection for kernel weight in spring wheat. Crop Science, v.22, p.568-572, 1982.

CHAMPOUX, M.C.; WANG, G.; SARKARUNG, S.; MaKILL, D.J.;O'TOOLE, J.C.; HUANG, N. \& McCOUCH, S.R. Locating genes associated with root morphology and drought avoidance in rice via linkage to molecular markers. Theoretical and Applied Genetics, v.90, p.969-981, 1995.

COMPTON, W.A. Recurrent selection in self-pollinated crops without extensive crossing. Crop Science, v.8, p.773, 1968.

CORDEIRO, C.M.T.; MIRANDA, J.E.C.; CAMPOS, J. Tamanho de parcelas e número de repetições em experimentos de batata. Revista Pesquisa Agropecuária Brasileira, v.17, n.9, p.1341-1348, 1982.

DIERS, B.W.; KEIM, P.; FEHR, W.R. \& SHOEMAKER, R.C. RFLP analysis of soybean seed protein and oil content. Theoretical and Applied Genetics, v.83, p.608-612, 1992.

DRAPER, N.R. \& SMITH, H. Applied regression analysis. 2.ed. New York: John Wiley, 1981. 709p.

EDWARDS, M. \& JOHNSON, L. RFLPs for Rapid Recurrent Selection. In: SYMPOSIUM OF ANALYSIS OF MOLECULAR MARKER DATA, Corvallis, 1994. Proceedings. Corvallis: American Society for Horticultural Science, 1994. p.33-40.

EDWARDS, M.D. \& PAGE, N.J. Evaluation of marker-assisted selection through computer simulation. Theoretical and Applied Genetics, v.88, p.376-382, 1994.

EDWARDS, M.D.; HELENTJARIS, T.; WRIGHT, S. \& STUBER, C.W. Molecular-marker-facilitated investigations of quantitative trait loci in maize.

4. Analysis based on genome saturation with isozyme and restrictions 
fragment lenght polymorphisms markers. Theoretical and Applied Genetics, v.83, p.765-774, 1992.

EDWARDS, M.D.; STUBER, C.W. \& WENDEL, J.F. Molecular-markerfacilitades investigations of quantitative-trait loci in maize. I.Numbers, genomic distribution and types of gene action. Genetics, v.116, p.113-125, 1987.

ELLIS, T.H.N. Restriction fragment lenght polymorphism markers in relation to quantitative characters. Theoretical and Applied Genetics, v.72, p.1-2, 1986.

ELLIS, T.H.N.; TURNER, L.; HELLENS, R.P.; LEE, D.; HARKER, C.L.; ENARD, C.; DOMONEY, C. \& DAVIES, D.R. Linkage maps in pea. Genetics, v.130, p.649-663, 1992.

EUCLYDES, R.F. Uso do sistema para simulação Genesys na avaliação de métodos de seleção clássicos e associados a marcadores moleculares. Viçosa, 1996. 149p. Tese (Doutorado) - Universidade Federal de Viçosa.

FALCONER, D.S. \& MaCKAY Introduction to quantitative genetics. 4.ed. New York: Longman, 1996.

FEHR, W.R. \& ORTIZ, L.B. Recurrent selection for yield in soybeans. J. Agric. Univ. Puerto Rico, v.54, p.222-232, 1975.

FERREIRA, D.F. Eficiência de Métodos de Mapeamento de Locos Quantitativos (QTLS) e da Seleção Assistida por Marcadores Moleculares Através de Simulação. Piracicaba, 1995. 210p. Tese (Doutorado) - Escola Superior de Agricultura "Luiz de Queiroz", Universidade de São Paulo.

FERREIRA, M.E. \& GRATTAPAGLIA, D. Introdução ao uso de marcadores RAPD, RFLP em análise genética. Brasília: EMBRAPA-CENARGEN, 1995. 220p.

FEURSTEIN, U.; BROWN, A.H.D. \& BURDON, J.J. Linkage of rust resistance genes from wild barley (Hordeum spontaneum) with isozyme markers. Plant Breeding, v.104, p.318-324, 1990. 
FLEISS, J. L. On the distribution of a linear combination of independent chi squares. Journal of the American Statistical Association, v.66, p.142144, 1971.

FOUILLOUX, G. \& BANNEROT, H. Selection methods in the common bean (Phaseolus vulgaris). In: GEPTS, P. (Ed.) Genetic Resources of Phaseolus Beans. Kluwer Academic Publishers, 1988. p.503-542.

FRASER, A.S. Simulation of genetic systems by automatic digital computers. I. Effects of linkage on rates of advance under selection. Aust. J. Biol. Sci., v. 10, p.492-499, $1957 b$.

FRASER, A.S. Simulation of genetic systems by automatic digital computers. I. Introduction. Aust. J. Biol. Sci., v.10, p.484-491, 1957 a.

FREY, K.J. The utility of hill plots in oats research. Euphytica, v.14, p.196-208, 1965.

FREYRE, R. ; DOUCHES, D.S. Development of a model for marker-assisted selection of specific gravity in diploid potato across environments. Crop Science, v.34, p.1361-1368, 1994.

GARLAND, M.L. \& FEHR, W.R. Selection for agronomic characters in hill and row plots of soybeans. Crop Science, v.21, p.591-595, 1981.

GERALDI, I.O. Seleção recorrente no melhoramento de plantas. In: I Taller Internacional Sobre Seleção Recorrente em Arroz, Goiânia, 1995. Resumos. Goiânia: CNPAF-EMBRAPA, 1995. p.6.

GIMELFARB, A. \& LANDE, R. Simulation of marker assisted selection for nonadditive traits. Genet. Res. Camb. v.64, p.127-136, 1994a.

GIMELFARB, A. \& LANDE, R. Simulation of marker assisted selection in hybrid populations. Genet. Res. Camb. v.63, p.39-47, 1994b.

GODDARD, M.E. A mixed model for analyses of data on multiple genetic markers. Theoretical and Applied Genetics, v.83, p.878-886, 1992

GUIMARAES, E.P. \& FEHR, W.R. Alternagies strategies of recurrent selection for seed yield of soybean. Euphytica, v.40, p.111-120, 1989. 
HALEY, C.S. \& KNOTT, S.A. A simple regression method for mapping quantitative trait loci in line crosse using flanking markers. Heredity, v.69, p.315-324, 1992.

HALLAUER, A.R. \& MIRANDA Fo., J.B. Quantitative genetics in maize breeding. 2.ed. Ames: The lowa State University Press, 1995.

HALWARD, T.; STALKER, H.T. \& KOCHERT, G. RFLP map of peanut. In: PHILLIPS, R.L. \& VASIL, I.K. (Ed.) DNA-based markers in plants. Dordrecht: Kluwer Academic Publishers, 1994. p.246-260.

HART, G.E. RFLP maps of bread wheat. In: PHILLIPS, R.L. \& VASIL, I.K. (Ed.) DNA-based markers in plants. Dordrecht: Kluwer Academic Publishers, 1994. p.327-358.

HELENTJARIS, T.; SLOCUM, M.; WRIGHT, S.; SCHAEFER, A. \& NIENHUIS,

$\mathrm{J}$. Construction of genetic linkage maps in maize and tomato using restriction fragment lenght polymorphisms. Theoretical and Applied Genetics, v.72, p.761-769, 1986.

HILL, W.G.; THOMPSON, R. Probabilities of non-positive definite betweengroup or genetic covariance matrices. Biometrics, v.34, p.429-439, 1978.

HULL, F.G. Recurrent selection and specific combining ability in corn. Journal of the American Society of Agronomy, v.37, p.134-45, 1945.

JENKINS, M.T. Segregation of genes affecting yield of grain in maize. Journal of the American Society of Agronomy, v.32, p.55-63, 1940.

JIANG, C. \& ZENG, Z.B. Multiple trait analysis of genetic mapping for quantitative trait loci. Genetics, v.140, p.1111-1127, 1995.

JULIER, C. GOUYON, B.; GEORGES, M. GUÉNET, F.L.; NAKAMURA, Y.; AVNER, $P$. Minisatellite linkage maps in the mouse by cross-hibridization with human probes containing tandem repeats. Proceedings of The National Academy of Sciences of the USA, v.87, p.4585-4589, 1990. 
KASHI, Y.; HALLERMAN, E.; SOLLER, M. Marker-assisted selection of candidate bulls for progeny testing programmes. Animal Production, v.51, p.63-74, 1990.

KEIM, P.; DIERS, B.W.; OLSON, T.C. \& SHOEMAKER, R. RFLP mapping in soybean: association between marker loci and variation in quantitative traits. Genetics, v.126, p.735-742, 1990.

KENWORTHY, W.J. \& BRIM, C.A. Recurrent selection in soybeans. I.Seed yield. Crop Science, v.19, p.315-318, 1979.

KHADR, F.H. \& FREY, K.J. Effectiveness of recurrent selection in oat breeding (Avena sativa L.). Crop Science, v.5, p.349-354, 1965.

KING, R.C. (Ed.) Handbook of Genetics: plants, plant viruses, and protists. New York: Plenum Press, 1974.

KLEINHOFS, A.; KILIAN, A. RFLP maps of barley. In: PHILLIPS, R.L. \& VASIL, I.K. (Ed.) DNA-based markers in plants. Dordrecht: Kluwer Academic Publishers, 1994. p.163-198.

KNAPP, S.J. Mapping quantitative trait loci. In: PHILLIPS, R.L. \& VASIL, I.K. (Ed.) DNA-based markers in plants. Dordrecht: Kluwer Academic Publishers, 1994. p.58-96.

KOCHERT, G. RFLP technology. In: PHILLIPS, R.L. \& VASIL, I.K. (Ed.) DNAbased markers in plants. Dordrecht: Kluwer Academic Publishers, 1994. p.8-38.

KOEBNER, R.M.D. \& MARTIN, P.K. Association of eyespot resistance in wheat cv. 'Cappelle-Desprez' with endopeptidase profile. Plant Breeding, v.104, p.312-317, 1990.

LANDE, R. \& THOMPSON, R. Efficiency of marker-assisted selection in the improvement of quantitative traits. Genetics, v.124, p.743-756, 1990.

LANDE, R. Marker-assisted selection in relation to traditional methods of plant breeding. In: STALKER, H.T. \& MURPHY, J.P. (Eds.) Plant Breeding in the 1990's. Wallingford: CAB International, 1992. p.437-451. 
LANDER, E.S. \& BOTSTEIN, D. Mapping mendelian factors underlying quantitative traits using RFLP linkage maps. Genetics, v.121, p.185-199, 1989.

LANDRY, B.S.; KESSELI, R.V.; FARRARA, B. \& MICHELMORE, R.W. A genetic map of lettuce (Lactuca sativa L.) with restriction fragment length polymorphism, isozyme, disease resistance and morphological markers. Genetics, v.116, p.331-337, 1987.

LIN, J.J. \& KUO, J. AFLP ${ }^{T M}$ : A novel PCR-based assay for plant and bacterial DNA fingerprinting. Gaithersburg, Focus, v.17, n.2. p.66-70, 1995.

MATZINGER, D.F. \& WERNSMAN, E.A. Four cycles of mass selection in a synthetic variety of an autogamous species Nicotiana tabacum L. Crop Science, v.8, p.239-243, 1968.

McFERSON, J.K. \& FREY, K.J. Three selection strategies to increase protein yield in oats. Journal of Genetics and Breeding, v.44, p.39-48, 1990.

McFERSON, J.K. \& FREY, K.J. Recurrent selection for protein yield of oat. Crop Science, v.31, p.1-8, 1991.

McNEAL, F.H.; McGUIRE, C.F. \& BERG, M.A. Recurrent selection for grain protein content in spring wheat. Crop Science, v.18, p.779-782, 1978.

MESSEGUER, R.; GANAL, M.; VICENTE, M.C.; YOUNG, N.D.; BOLKAN, H. \& TANKSLEY, S.D. High resolution RFLP map around the root knot nematode resistance gene $(M i)$ in tomato. Theoretical and Applied Genetics, v.82, p.529-536, 1991.

MICHELMORE, R.W.; KESSELI, R.V.; RYDER, E.J. Genetic mapping in lettuce. In: PHILLIPS, R.L. \& VASIL, I.K. (Ed.) DNA-based markers in plants. Dordrecht: Kluwer Academic Publishers, 1994. p.223-239.

MIKLAS, P.N.; AFANADOR, L. \& KELLY, J.D. Recombination-facilitated RAPD marker-assisted selection for disease resistance in common bean. Crop Science, v.36, p.86-90, 1996. 
MILLER, J.E. \& FEHR, W.R. Direct and indirect selection for protein in soybeans. Crop science, v.19, p.101-106, 1979.

MOOD, A.M.; GRAYBILL, F.A.; BOES, D.C. Introduction to the theory of statistics. Tokyo: McGraw-Hill Kogakusha, 1974.

NIENHUIS, J.; HELENTJARIS, T.; SLOCUM, M.; RUGGERO, B. \& SCHAEFER, A. Restriction fragment lenght polymorphism analysis of loci associated with insect resistance in tomato. Crop Science, v.27, p.797-803, 1987.

NODARI, R.O.; TSAI, S.M.; GILBERTSON, R.L. \& GEPTS, P. Towards an integrated linkage map of common bean. 2. Development of an RFLP-based linkage map. Theoretical and Applied Genetics, v.85, p.513-520, 1993.

O'DONOUGHUE, L.S.; RAYAPATI, P.J.; KIANIAN, S.F.; SORRELLS, M.E.; TANKSLEY, S.D.; LEE, M.; RINES, H.W.; PHILLIPS, R.L. Development of RFLP-based linkage maps in diploid and hexaploid oat (Avena sp.). In: PHILLIPS, R.L. \& VASIL, I.K. (Ed.) DNA-based markers in plants. Dordrecht: Kluwer Academic Publishers, 1994. p.359-374.

OSBORN, T.C.; ALEXANDER, D.C. \& FOBES, J.F. Identification of restriction fragment lenght polymorphisms linked to genes contolling soluble solids content in tomato fruit. Theoretical and Applied Genetics, v.73, p.350-356, 1987.

OWEN, A.R.G. The theory of genetical recombination. I. Long-chromosome arms. Proceedins of the Royal Statistical Society, Series B, v.136, p.6794, 1949.

PATERSON, A.H.; DAMON, S.; HEWITT, J.D.; ZAMIR, D.; RABINOWITCH, H.D.; LINCOLN, S.E.; LANDER, E.S. \& TANKSLEY, S.D. Mendelian factors underlying quantitative traits in tomato: comparison across species, generations, and environments. Genetics, v.127, p.181-197, 1991.

PATERSON, A.H.; DeVERNA, J.W.; LANINI, B. \& TANKSLEY, S.D. Fine mapping of quantitative trait loci using selected overlapping recombinant 
chromosomes, in an interspecies cross of tomato. Genetics, v.124, p.735$742,1990$.

PAYNE, T.S.; STUTHMAN, D.D.; MCGRAW, R.L. \& BREGITZER, P.P. Physiological changes associated with three cycles of recurrent selection for grain yield improvement in oats. Crop Science, v.26, p.734-736, 1986.

POMERANKE, G.J. \& STUTHMAN, D.D. Recurrent selection for increased grain yield in oat. Crop Science, v.32, p.1184-1187, 1992.

PROHASCA, K.R. \& FEHR, W.R. Recurrent selection for resistance to iron deficiency chlorosis in soybeans. Crop Science, v.21, p.524-526, 1981.

RAMALHO, M.A.P.; SANTOS, J.B. \& ZIMMERMANN, M.J.O. Genética quantitativa em plantas autógamas. 1.ed. Goiânia: UFG, 1993. 271pp.

RAMALHO, M.A.P. \& VENCOVSKY, R. Estimação dos componentes da variância genética em plantas autógamas. Ciência e Prática, v.2, n.2, p.117-140, 1978.

RANGEL, P.H.N. \& NEVES, P.C.F. Seleção recorrente em arroz irrigado no Brasil: guia prático. Goiânia: CNPAF-EMBRAPA, 1995a. 24p. (EMBRAPACNPAF: Documentos, 53).

RANGEL, P.H.N. \& NEVES, P.C.F. Seleção recorrente em arroz irrigado no Brasil In: I Taller Internacional Sobre Seleção Recorrente em Arroz, Goiânia, 1995. Resumos. Goiânia: CNPAF-EMBRAPA, 1995. p.114.

REITER, R.S.; COORS, J.G.; SUSSMAN, M.R.; GABELMAN, W.H. Genetic analysis of tolerance to low-phosphorus in maize using restriction fragment lenght polymorphisms. Theoretical and Applied Genetics, v.82, p.561-568, 1991.

RUIZ, A.; BARBADILLA, A. The contribution of quantitative trait loci and neutral marker loci to the genetic variances and covariances among quantitative traits in random mating populations. Genetics, v.139, p.445-455, 1995. 
SCHNICKER, B.J. \& LAMKEY, K.R. Interpopulation genetic variance after reciprocal recurrent selection in BSSS and BSCB1 maize populations. Crop Science, v.33, p.90-95, 1993.

SAX, K. The association of size differences with seed coat pattern and pigmentation in Phaseolus vulgaris. Genetics, v.8, p.552-560, 1923.

SEARLE, S. R. Linear models. New York: McGraw-Hill. 1971.

SHOEMAKER, R.C. RFLP map of soybean. In: PHILLIPS, R.L. \& VASIL, I.K. (Ed.) DNA-based markers in plants. Dordrecht: Kluwer Academic Publishers, 1994. p.299-309.

SMITH, C. ; SIMPSON, S.P. The use of genetic polymorphisms in livestock improvement. Journal of Animal Breeding and Genetics, v.103, p.205217, 1986.

SMITH, H.F. An empirical law describing heterogeneity in the yields of agricultural crops. Journal of Agricultural Science, v.28, p.1-23, 1938.

SOUZA JR., C.L. Componentes da variância genética e suas implicações no melhoramento vegetal. Piracicaba: FEALQ, 1989. 134p.

STEBBINS, G.L. Chromosomal evolution in higher plants: a series of student texts in contemporary biology. Reading: Addison-Wesley, 1971. 216p.

STEEL, R.G.D. \& TORRIE, J.H. Principles and procedures of statistics. New York: McGraw-Hill, 1980, 633p.

STROMBERG, L.D.; DUDLEY, J.W.; RUGENER, F.K. Comparing conventional early generation selection with molecular marker assisted selection in maize. Crop Science, v.34, p.1221-1225, 1994.

STUBER, C.W.; EDWARDS, M.D. \& WENDEL, J.F. Molecular markerfacilitated investigations of quantitative trait loci in maize. II,Factors influencing yield and its component traits. Crop Science, v.27, p.639-648, 1987. 
STUBER, C.W.; GOODMAN, M.M. \& MOLL, R.H. Improvement of yield and ear number resulting from selection at allozime loci in a maize population. Crop Science, v.22, p.737-740, 1982.

SUMARNO \& FEHR, W.R. Response to recurrent selection for yield in soybeans. Crop Science, v.22, p.295-299, 1982.

TANKSLEY, S.D. Mapping polygenes. Annual Review of Genetics. v.27, p.205-233, 1993.

TANKSLEY, S.D. Rice molecular map. In: PHILLIPS, R.L. \& VASIL, I.K. (Ed.) DNA-based markers in plants. Dordrecht: Kluwer Academic Publishers, 1994. p.310-326.

TANKSLEY, D.; MEDINA-FILHO, H. \& RICK, C.M. The effect of isozyme selection on metric characters in an interspecific backcross of tomato - basis of an early screening procedure. Theoretical and Applied Genetics, v.60, p.291-296, 1981.

TANKSLEY, S.D. \& HEWITT, J. Use of molecular markers in breeding for soluble solids content in tomato - a re-examination. Theoretical and Applied Genetics, v.75, p.811-823, 1988.

TANKSLEY, S.D. \& RICK, C.M. Isozymic gene linkage map of the tomato: applications in genetics and breeding. Theoretical and Applied Genetics, v.57, p.161-170, 1980.

THODAY, J.M. Location of polygenes. Nature, v.191, p.268-370, 1961.

VALLEJOS, C.E. Phaseolus vulgaris: the common bean. In: PHILLIPS, R.L. \& VASIL, I.K. (Ed.) DNA-based markers in plants. Dordrecht: Kluwer Academic Publishers, 1994. p.261-270.

VENCOVSKY, R. \& BARRIGA, P. Genética biométrica no fitomelhoramento. Ribeirão Preto: Revista Brasileira de Genética, 1992. 496p.

$X U, H . \&$ WILCOX, J.R. Recurrent selection for maturity and percent seed protein in Glycine max based on $S_{0}$ plant evaluations. Euphytica, v.62, p.51-57, 1992 
WEEDEN, N.F. \& PROWIDENTI, R. A marker locus, Adh-1, for resistance to pea enation mosaic virus in Pisum sativum. The Journal of Heredity, v.79, n.2, p.128-131, 1988.

WELLER, J.I.; SOLLER, M. \& BRODY, T. Linkage analysis of quantitative traits in an interspecific cross of tomato (Lycopersicon esculentum $\times$ Lycopersicon pimpinellifolium) by means of genetic markers. Genetics, v.118, p.329-339, 1988.

WERNER, B.K. \& WILCOX, J.R. Recurrent selection for yield in Glycine max using genetic male-sterility. Euphytica, v.50, p.19-26, 1990.

WILLIAMS, J.G.; KUBELIK, A.R.; LIVAK, K.J.; RAFALSKI, L.A. \& TINGEY, S.V. DNA polymorphism amplified by arbitrary primers are useful as fenetic markers. Nucleic Acids Research, v.18, p.6531-6535, 1990.

ZABEAU, M. Selective restriction fragment amplification: a general method for DNA fingerprinting. European Patent Application n. 0534858 A1. 1993.

ZHANG, W. \& SMITH, C. Computer simulation of marker-assisted selection utilizing linkage disequilibrium. Theoretical and Applied Genetics, v.83, p.813-820, 1992. 
APÊNDICE 1

(TABELAS) 
Tabela 1. Frequência relativa esperada do número de linhagens com pelo menos a metade do número de locos $(n)$ com alelos favoráveis fixados, estando estes em diferentes frequências $p_{f}$.

\begin{tabular}{|c|c|c|c|c|c|c|}
\hline $\mathrm{n}$ & $p_{f}$ & 0,1 & 0,3 & 0,5 & 0,7 & 0,9 \\
\hline 10 & & 0,0016 & 0,1503 & 0,6230 & 0,9527 & 0,9999 \\
\hline 20 & & 0,0001 & 0,0480 & 0,5881 & 0,9829 & $\cong 1,0000$ \\
\hline 40 & & $\cong 0,0000$ & 0,0063 & 0,5627 & 0,9976 & $\cong 1,0000$ \\
\hline 80 & & $\cong 0,0000$ & 0,0001 & 0,5445 & 0,999 & $\cong 1,0000$ \\
\hline
\end{tabular}

Tabela 2. Número esperado de locos fixados com o alelo favorável, na melhor linhagem, utilizando o método de descendentes de uma única semente por várias gerações, variando o número total de locos (n), e o número de linhagens endogâmicas avaliadas $(\mathrm{N})$.

\begin{tabular}{rrrll}
\hline $\mathrm{N}$ & $\mathrm{n}=10$ & $\mathrm{n}=20$ & $\mathrm{n}=40$ & $\mathrm{n}=100$ \\
\hline 25 & 8,1 & 14,4 & 26,3 & 59,9 \\
50 & 8,6 & 14,9 & 27,1 & 61,3 \\
100 & 9,0 & 15,6 & 27,9 & 62,6 \\
200 & 9,4 & 16,1 & 28,7 & 63,8 \\
400 & 9,7 & 16,6 & 29,4 & 64,9 \\
800 & 10,0 & 17,1 & 30,1 & 65,9 \\
1.000 & 10,0 & 17,2 & 30,2 & 66,2 \\
5.000 & 10,0 & 18,2 & 31,6 & 68,4 \\
10.000 & 10,0 & 18,6 & 32,2 & 69,2 \\
\hline
\end{tabular}

Fonte: Fouilloux \& Bannerot (1988). 
Tabela 3. Número esperado de locos com alelos favoráveis fixados nas duas melhores linhagens $\left(L_{11}\right.$ e $\left.L_{21}\right)$ e na melhor linhagem $\left(L_{12}\right)$ de um primeiro e um segundo ciclos seletivos, respectivamente, com um total de 40 locos controladores da característica, e diferentes números de linhagens avaliadas $(\mathrm{N})$ em cada ciclo.

\begin{tabular}{rlll}
\hline $\mathrm{N}$ & $\mathrm{L}_{11}$ & $\mathrm{~L}_{21}$ & $\mathrm{~L}_{12}$ \\
\hline 50 & 27,1 & 25,9 & 31,3 \\
100 & 27,9 & 26,8 & 32,6 \\
200 & 28,7 & 27,6 & 33,8 \\
400 & 29,4 & 28,4 & 34,8
\end{tabular}

Fonte: Fouilloux \& Bannerot (1988).

Tabela 4. Número necessário $\left(N_{1}\right)$ de linhagens avaliadas para se obter, em um único ciclo seletivo, o mesmo número médio de locos com o alelo favorável fixado, de um total de 40 locos, em 2 ciclos de seleção recorrente, utilizando $\mathbf{N}$ linhagens em cada ciclo, e a relação entre os custos dos dois sistemas de seleção.

\begin{tabular}{rrc}
\hline $\mathbf{N}$ & \multicolumn{1}{c}{$\mathbf{N}_{\mathbf{1}}$} & Relação Entre Custos \\
\hline 50 & 3.500 & 35 \\
100 & 18.800 & 94 \\
200 & 116.000 & 291 \\
400 & 543.000 & 679 \\
\hline
\end{tabular}

Fonte: Fouilloux \& Bannerot (1988) 


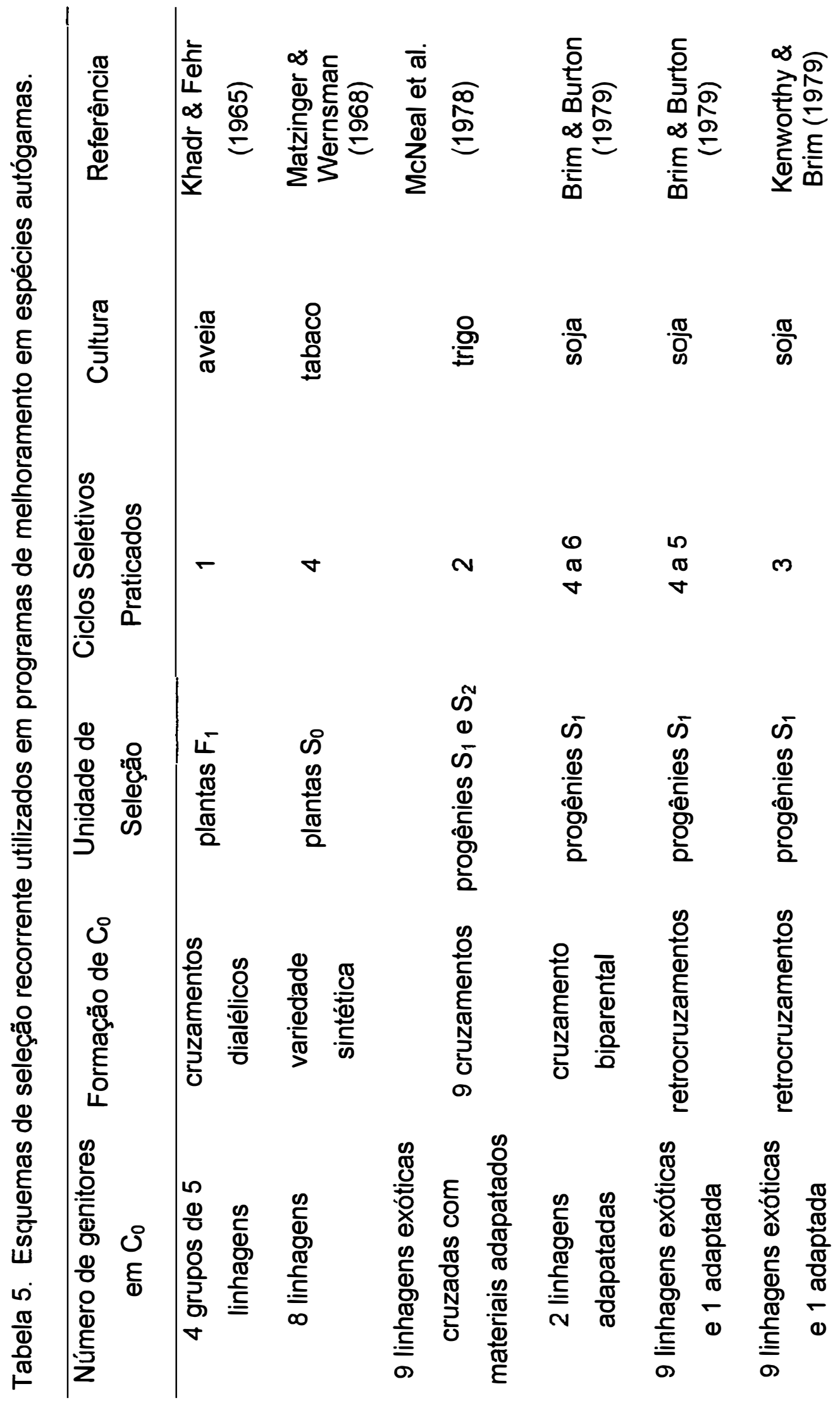




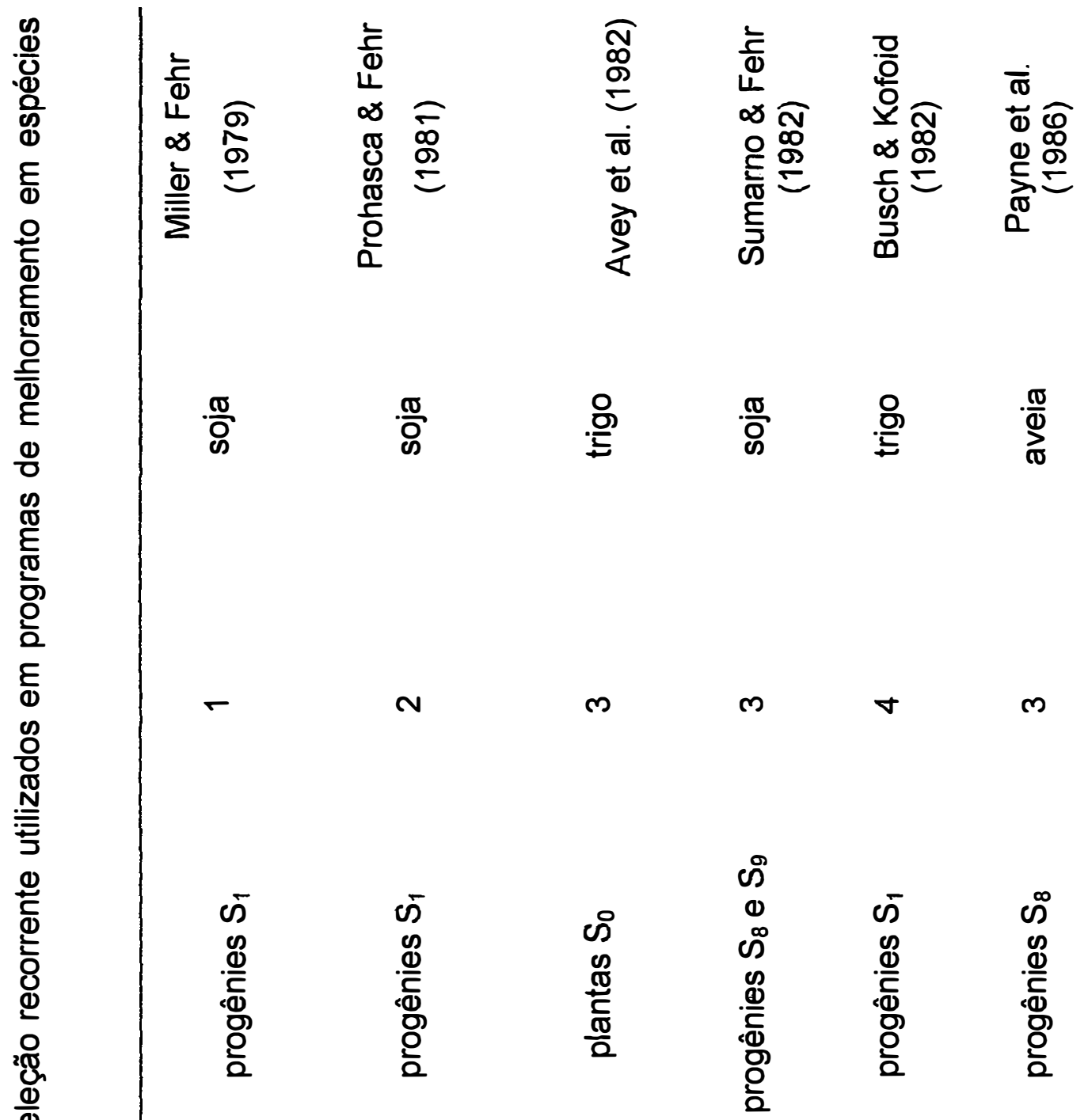

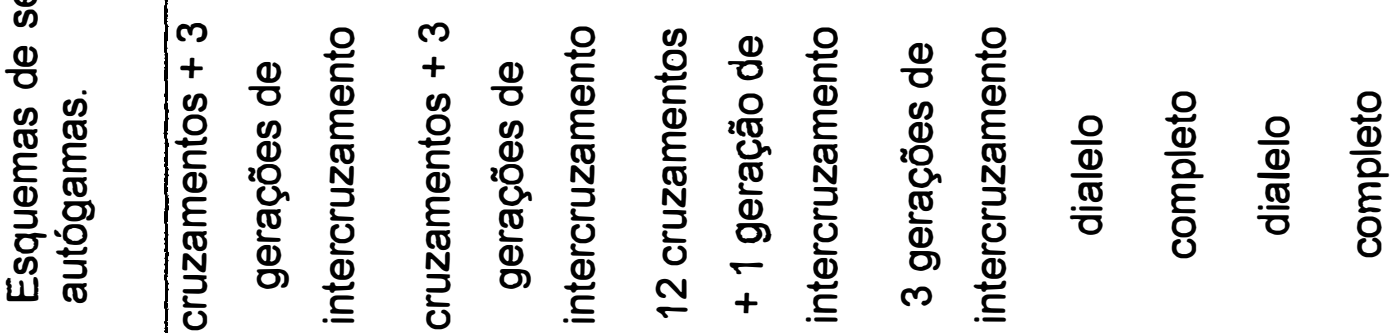

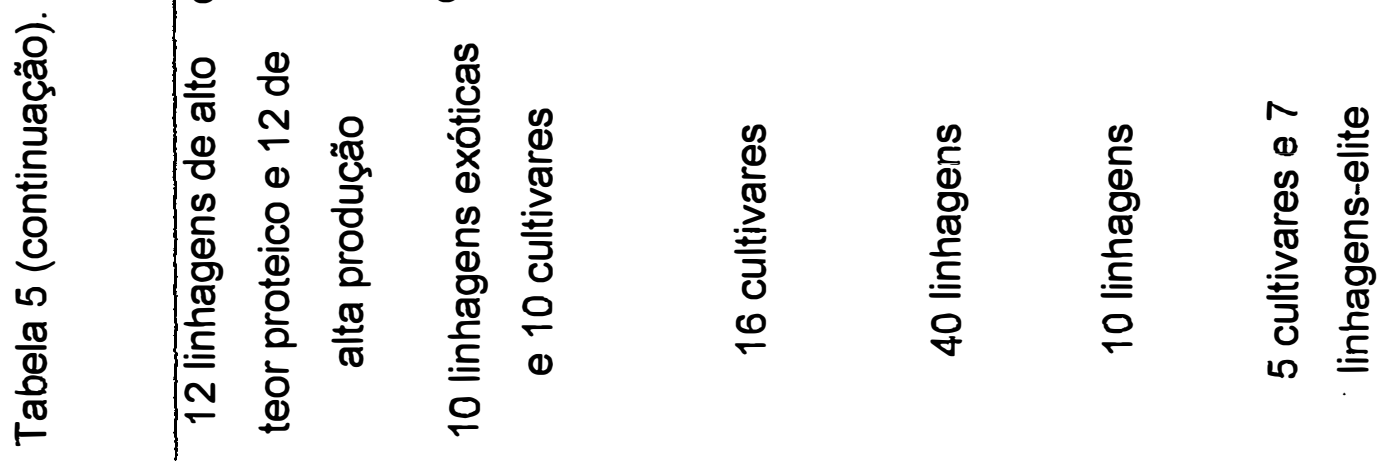




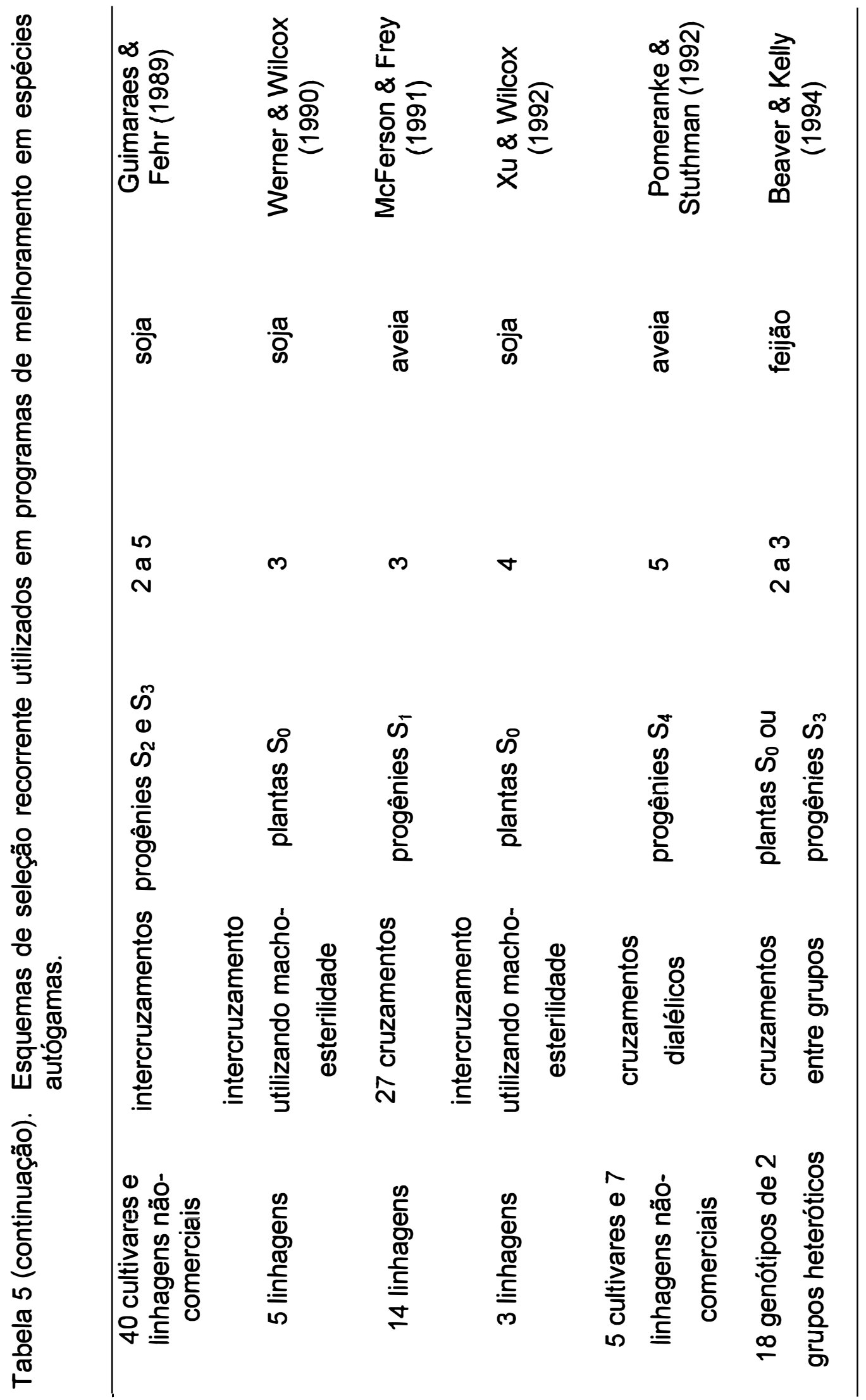


Tabela 6. Desequilíbrio de ligação em espécies autógamas, em diferentes gerações de autofecundação e frequências de recombinação (r).

\begin{tabular}{lcccc}
\hline $\begin{array}{l}\text { Geração } \\
r\end{array}$ & $F_{1}$ & $F_{2}$ & $F_{3}$ & $F_{4}$ \\
\hline 0,40 & 0,2500 & 0,0500 & 0,0300 & 0,0260 \\
0,30 & 0,2500 & 0,1000 & 0,0700 & 0,0580 \\
0,20 & 0,2500 & 0,1500 & 0,1200 & 0,1020 \\
0,10 & 0,2500 & 0,2000 & 0,1800 & 0,1640 \\
0,05 & 0,2500 & 0,2250 & 0,2138 & 0,2036
\end{tabular}

Tabela 7. Número mínimo de locos marcadores necessário para detectar um nível substancial de associação com QTL's em plantas, considerando um genoma de 10 Morgans e 10 grupos de ligação, em diferentes sistemas reprodutivos e núm:eros de gerações após hibridação.

\begin{tabular}{ccc}
\hline $\begin{array}{c}\text { Número de Gerações } \\
\text { Após Hibridação }\end{array}$ & Alogamia & Autogamia \\
\hline 1 & 30 & 30 \\
5 & 110 & 49 \\
10 & 210 & 50 \\
\hline
\end{tabular}

Fonte: Lande \& Thompson (1990). 
Tabela 8. Eficiência esperada da seleção assistida por marcadores, em relação à seleção baseada na informação fenotípica, considerando diferentes valores de herdabilidade $\left(\mathrm{h}^{2}\right)$ e da proporção da variância genética explicada por marcadores moleculares $(p)$.

\begin{tabular}{|c|c|c|c|}
\hline$h^{2}$ & 0,10 & 0,50 & 0,80 \\
\hline 0,15 & 1,22 & 1,90 & 2,32 \\
\hline 0,30 & 1,08 & 1,40 & 1,65 \\
\hline 0,50 & 1,03 & 1,15 & 1,29 \\
\hline 0,80 & 1,00 & 1,02 & 1,05 \\
\hline
\end{tabular}

Tabela 9. Número necessário de grupos genéticos que devem ser avaliados para que a razão entre os ganhos médios com índices de seleção, utilizando estimativas e utilizando valores paramétricos, seja no mínimo igual a $90 \%$, considerando 2 características ${ }^{1}$.

\begin{tabular}{|c|c|c|c|c|c|}
\hline \multicolumn{6}{|c|}{$r_{P}$} \\
\hline 0,8 & 0,7 & 0,6 & 0,5 & 0,4 & 0,3 \\
\hline 7 & 10 & 14 & 21 & 35 & 64 \\
\hline
\end{tabular}


Tabela 10. Correlação entre o valor genético e o índice de seleção de Lande \& Thompson (1990), em diferentes níveis de herdabilidade $\left(h^{2}\right)$ e da proporção da variância genética explicada por marcadores ( $p$ ).

\begin{tabular}{|c|c|c|c|c|c|}
\hline$h^{2}$ & $p$ & 0,05 & 0,20 & 0,50 & 0,70 \\
\hline 0,15 & & 0,432 & 0,547 & 0,735 & 0,846 \\
\hline 0,50 & & 0,716 & 0,745 & 0,816 & 0,877 \\
\hline 0,75 & & 0,868 & 0,874 & 0,894 & 0,918 \\
\hline
\end{tabular}

Tabela 11. Esquema de análise de variância, ilustrando a partição da variação entre t progênies, dispostas em $r$ repetições, em uma fonte devida a um modelo de regressão associado a $k$ locos marcadores, e outra aos desvios de regressão.

\begin{tabular}{lcc}
\hline \multicolumn{1}{c}{ Causas de Variação } & Graus de Liberdade & Quadrados Médios \\
\hline Progênies & $(t-1)$ & QMT \\
Regressão & $k$ & QMR \\
Desvios & $(t-k-1)$ & QMD \\
Resíduo & $t(r-1)$ & QME \\
\hline Total & $t r-1$ & - \\
\hline
\end{tabular}


Tabela 12. Valores atribuídos, na simulação em computador, a parâmetros possivelmente influentes na eficiência da seleção assistida por marcadores, tendo progênies endogâmicas como unidades de seleção ${ }^{1}$.

\begin{tabular}{|c|c|c|c|}
\hline Parâmetro & \multicolumn{3}{|c|}{ Atribuições } \\
\hline $\mathrm{N}$ & 5 & & \\
\hline $\mathrm{n}$ & 400 & 300 & 160 \\
\hline $\begin{array}{c}\text { Sistema de } \\
\text { Obtenção de Progênies }\end{array}$ & $\begin{array}{c}\text { Precoce } \\
\left(10 \text { plantas } S_{1}\right)\end{array}$ & & $\begin{array}{l}\text { çado } \\
\text { itas } \mathrm{S}_{3} \text { ) }\end{array}$ \\
\hline$h^{2}$ & 0,025 & 0,050 & 0,100 \\
\hline$d / a$ & 0 & & \\
\hline $\begin{array}{l}\text { Proporção de Progênies } \\
\text { Selecionadas }\end{array}$ & 10 & & 0,25 \\
\hline Seleção & Fenotípica & & $\begin{array}{l}\text { da por } \\
\text { dores }\end{array}$ \\
\hline $\begin{array}{l}\text { Coeficiente de Heterogeneidade } \\
\text { do Solo de Smith (1938) }\end{array}$ & 0,5 & 0,2 & 0,8 \\
\hline Número de Locos Marcadores & 130 & 30 & 200 \\
\hline
\end{tabular}


Tabela 13. Valores de variância genética aditiva e total (assumindo ocorrência de dominância positiva completa), obtidos pela geração aleatória de 20.000 indivíduos em cada um de 5 cruzamentos entre linhagens endogâmicas simuladas.

\begin{tabular}{crc}
\hline Cruzamento & \multicolumn{1}{c}{ Vditiva $^{1}$} & Total \\
\hline$L_{1} \times L_{2}$ & $5,6(9,4)$ & 13,2 \\
$L_{2} \times L_{3}$ & $15,0(14,1)$ & 22,3 \\
$L_{3} \times L_{4}$ & $10,1(9,9)$ & 15,8 \\
$L_{4} \times L_{5}$ & $10,3(8,5)$ & 14,6 \\
$L_{5} \times L_{1}$ & $10,9(9,8)$ & 16,2 \\
\hline Médias & $10,38(10,34)$ & 16,42
\end{tabular}

1. Valores entre parênteses correspondem à variância aditiva em equilíbrio de ligação.

Tabela 14. Esquema da análise de variância, em um ensaio de uniformidade contendo $\lambda$ blocos, cada qual com $\mathrm{m}$ parcelas de $x$ plantas.

\begin{tabular}{lcc}
\hline \multicolumn{1}{c}{ Causas de Variação } & Graus de Liberdade & Quadrados Médios \\
\hline Entre Blocos & $(\lambda-1)$ & $\mathrm{m}\left(\mathrm{V}_{\mathrm{xm}}\right)_{\lambda}$ \\
Dentro de Blocos & $\lambda(m-1)$ & $\left(\mathrm{V}_{\mathrm{x}}\right)_{\mathrm{m}}$ \\
\hline Total & $\lambda m-1$ & $\left(\mathrm{~V}_{\mathrm{x}}\right)_{\lambda m}$
\end{tabular}


Tabela 15. Esquema da análise de variância, em um ensaio de uniformidade, com o número de parcelas tendendo ao infinito, e $\mathrm{m}$ plantas por parcela.

\begin{tabular}{lll}
\hline \multicolumn{1}{c}{ Causas de Variaçāo } & \multicolumn{2}{c}{ Quadrados Médios (QM) } \\
\hline Entre Parcelas & QMEP $=\mathrm{m}\left(\mathrm{V}_{\mathrm{m}}\right)_{\infty}=\sigma_{\mathrm{w}}^{2}+\mathrm{m} \sigma_{\mathrm{e}}^{2}$ \\
Dentro de Parcelas & QMDP $=\left(\mathrm{V}_{1}\right)_{\mathrm{m}}=\sigma_{\mathrm{w}}^{2}$ \\
\hline Total & QMTP $=\left(\mathrm{V}_{1}\right)_{\infty}=\sigma^{2}=\sigma_{\mathrm{w}}^{2}+\sigma_{\mathrm{e}}^{2}$ \\
\hline
\end{tabular}

Tabela 16. Esperanças de quadrados médios associados à avaliação de $t$ progênies em um delineamento inteiramente ao acaso com $r$ repetições, com desdobramento da variação entre progênies em uma fonte relativa a um modelo de regressão associado a $\mathrm{k}$ locos marcadores, e outra ao desvio da regressão.

\begin{tabular}{lcc}
\hline \multicolumn{1}{c}{ Causas de Variação } & Graus de Liberdade & \multicolumn{1}{c}{$E(Q M)$} \\
\hline Progênies & $(t-1)$ & $\sigma^{2}+r \sigma_{h}^{2}+r \sigma_{G}^{2}$ \\
Regressão & $k$ & $\sigma^{2}+r \sigma_{h}^{2}+\frac{r(t-1)}{k} \sigma_{M}^{2}$ \\
$\quad$ Desvios & $(t-k-1)$ & $\sigma^{2}+r \sigma_{h}^{2}$ \\
Resíduo & $t(r-1)$ & $\sigma^{2}$ \\
\hline Total & $t r-1$ & - \\
\hline
\end{tabular}


Tabela 17. Aproximações de $E[\hat{p}]$ e $V[\hat{p}]$, para $k=5$ locos marcadores, $r=2$ repetições e números diferentes de progênies avaliadas $(t)$, da herdabilidade $\left(h^{2}\right)$, e da proporção da variância genética explicada por marcadores $(p)$.

\begin{tabular}{|c|c|c|c|}
\hline & $t$ & $E[\hat{p}]$ & $\mathrm{V}[\hat{\mathrm{p}}]$ \\
\hline$p=0,1$ & $\begin{array}{r}10 \\
50 \\
100 \\
400 \\
1.000 \\
5.000 \\
10.000\end{array}$ & $\begin{array}{l}0,5192 \\
0,1353 \\
0,1135 \\
0,1003 \\
0,0979 \\
0,0967 \\
0,0966\end{array}$ & $\begin{array}{l}6,910968 \\
0,154493 \\
0,048569 \\
0,009573 \\
0,005398 \\
0,003632 \\
0,003434\end{array}$ \\
\hline$h^{2}=0,2$ & $\begin{array}{r}10 \\
50 \\
100 \\
400 \\
1.000 \\
5.000 \\
10.000 \\
\end{array}$ & $\begin{array}{l}5,4696 \\
1,4833 \\
1,1597 \\
0,9378 \\
0,8954 \\
0,8731 \\
0,8704 \\
\end{array}$ & $\begin{array}{l}8,978484 \\
0,665417 \\
0,299072 \\
0,071156 \\
0,029944 \\
0,008532 \\
0,005883 \\
\end{array}$ \\
\hline$p=0,1$ & $\begin{array}{r}10 \\
50 \\
100 \\
400 \\
1.000 \\
5.000 \\
10.000\end{array}$ & $\begin{array}{l}0,0680 \\
0,0888 \\
0,0925 \\
0,0954 \\
0,0960 \\
0,0963 \\
0,0964\end{array}$ & $\begin{array}{l}0,413762 \\
0,017056 \\
0,008451 \\
0,004262 \\
0,003628 \\
0,003315 \\
0,003278\end{array}$ \\
\hline$h^{2}=0,8$ & $\begin{array}{r}10 \\
50 \\
100 \\
400 \\
1.000 \\
5.000 \\
10.000 \\
\end{array}$ & $\begin{array}{l}0,8786 \\
0,8678 \\
0,8676 \\
0,8676 \\
0,8676 \\
0,8676 \\
0,8676 \\
\end{array}$ & $\begin{array}{l}0,061130 \\
0,006536 \\
0,004630 \\
0,003543 \\
0,003358 \\
0,003263 \\
0,003252 \\
\end{array}$ \\
\hline
\end{tabular}




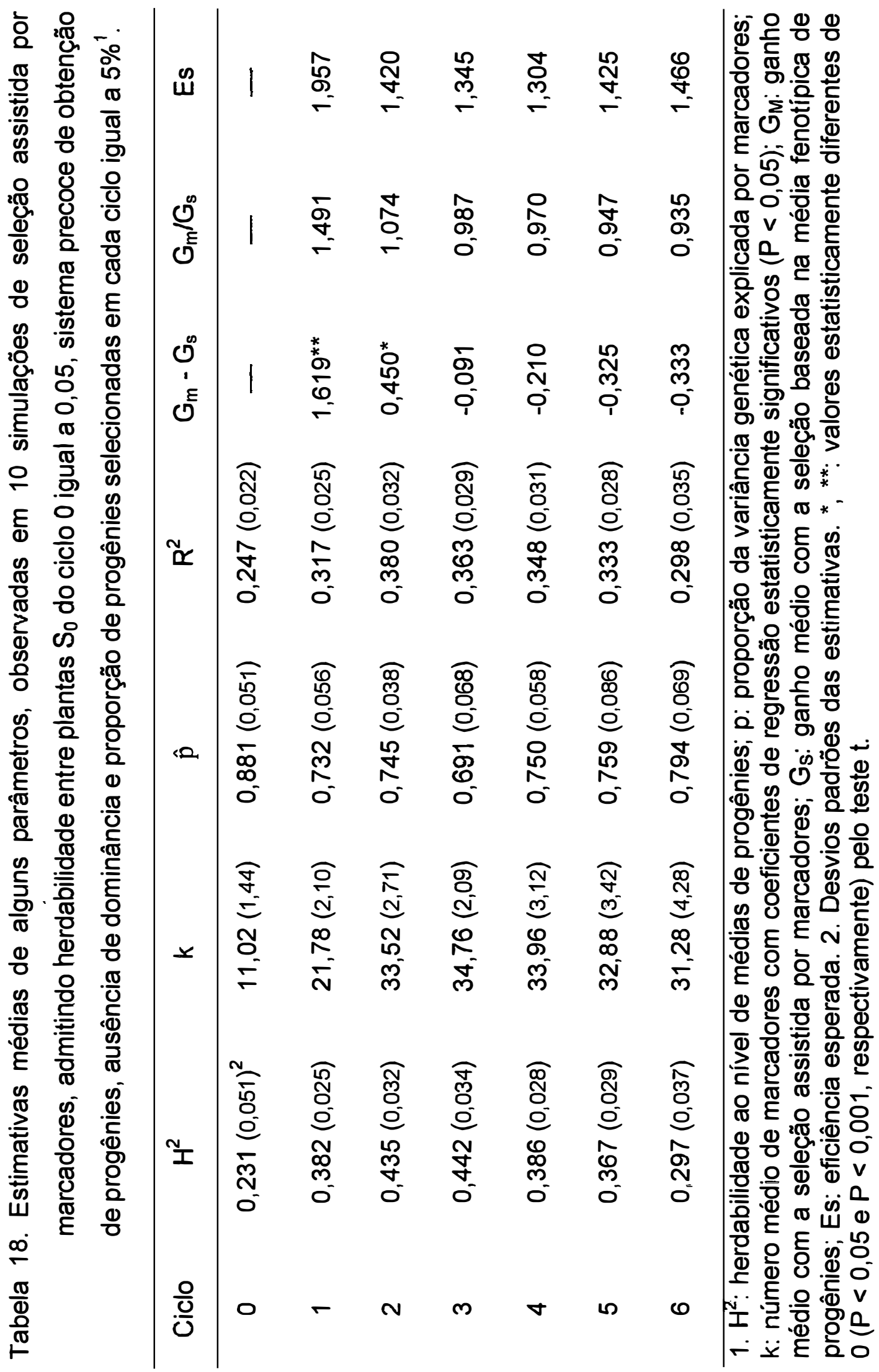


Tabela 19. Análise de variância e estimativas de parâmetros obtidas em 5 cruzamentos do ciclo 0 , na simulacaão de um programa de seleção assistida por marcadores, com $\mathrm{h}^{2}$ entre plantas $\mathrm{S}_{0}$ igual a 0,05 , sistema precoce de obtenção de progênies, ausência de dominância e proporção de progênies selecionadas igual a $5 \%$.

\begin{tabular}{|c|c|c|c|c|c|}
\hline \multicolumn{6}{|c|}{ CRUZAMENTO 1} \\
\hline $\mathrm{CV}$ & GL & QM & $\mathrm{H}^{2}$ & & $?^{2}$ \\
\hline Progênie & (399) & 83,6592 & 0,241 & & 14 \\
\hline Regressão & 10 & 713,1513 & $\hat{\mathrm{p}}$ & $r$ & $b_{M}$ \\
\hline Desvio & 389 & 67,4769 & 0,80 & 0,588 & 15,85 \\
\hline Erro & 400 & 63,4732 & \multirow{2}{*}{\multicolumn{3}{|c|}{$\begin{array}{c}\text { Modelo estimado }: y=-24,82+0,83 X_{6}+2,36 X_{21}+ \\
-1,95 X_{31}+1,49 X_{43}-1,48 X_{61}+1,26 X_{81}+1,16 X_{83}+ \\
-1,68 X_{88}-0,99 X_{91}-1,33 X_{106}\end{array}$}} \\
\hline Total & 799 & - & & & \\
\hline
\end{tabular}

CRUZAMENTO 2

\begin{tabular}{lrr}
\hline CV & \multicolumn{1}{c}{ GL } & \multicolumn{1}{c}{ QM } \\
\hline Progênie & $(399)$ & 96,3548 \\
Regressão & 16 & 752,1419 \\
Desvio & 383 & 68,9590 \\
Erro & 400 & 68,0971 \\
\hline Total & 799 & - \\
\hline
\end{tabular}

\begin{tabular}{ccc}
\hline$H^{2}$ & \multicolumn{1}{c}{$R^{2}$} \\
0,293 & & 0,313 \\
\hline$\hat{p}$ & $r$ & $b_{M}$ \\
0,97 & 0,791 & 79,01 \\
\hline Modelo estimado': $y=-13,01-0,87 X_{5}+2,02 X_{15}-$ \\
$-1,55 X_{23}-1,31 X_{25}-1,27 X_{30}+0,98 X_{35}-2,52 X_{45}-$ \\
$+1,18 X_{55}+1,09 X_{58}+1,68 X_{60}-0,96 X_{78}+$ \\
$+0,95 X_{80}-1,37 X_{83}-0,98 X_{85}-2,79 X_{108}-1,04 X_{110}$ \\
\hline
\end{tabular}

CRUZAMENTO 3

\begin{tabular}{|c|c|c|c|c|c|}
\hline $\mathrm{CV}$ & GL & QM & $\mathrm{H}^{2}$ & & \\
\hline Progênie & (399) & 90,8420 & 0,325 & & \\
\hline Regressão & 12 & 792,1467 & $\hat{\mathrm{p}}$ & $r$ & $b_{M}$ \\
\hline Desvio & 387 & 69,0961 & 0,74 & 0,787 & 7,90 \\
\hline Erro & 400 & 61,3352 & \multirow{2}{*}{\multicolumn{3}{|c|}{$\begin{array}{l}\text { Modelo estimado }: y=-15,96-1,57 X_{5}-1,10 X_{7}+ \\
-2,34 X_{17}-1,34 X_{37}+1,25 X_{60}+1,46 X_{75}-1,16 X_{82}+ \\
+1,34 X_{87}+0,92 X_{97}-2,21 X_{107}-1,07 X_{115}-0,92 X_{130}\end{array}$}} \\
\hline Total & 799 & - & & & \\
\hline
\end{tabular}


Tabela 19 (continuação). Análise de variância e estimativas de parâmetros obtidas em 5 cruzamentos do ciclo 0 , na simulação de um programa de seleção assistida por marcadores, com $h^{2}$ entre plantas $S_{0}$ igual a 0,05 , sistema precoce de obtenção de progênies, ausência de dominância e proporção de progênies selecionadas igual a $5 \%$.

CRUZAMENTO 4

\begin{tabular}{|c|c|c|c|c|c|}
\hline $\mathrm{CV}$ & GL & QM & $\mathrm{H}^{2}$ & & $?^{2}$ \\
\hline Progênie & (399) & 87,6426 & 0,133 & & 283 \\
\hline Regressão & 16 & 619,2983 & $\hat{\mathrm{p}}$ & $r$ & $b_{M}$ \\
\hline Desvio & 383 & 65,4324 & 1,91 & 0,823 & $-7,18$ \\
\hline Erro & 400 & 76,0274 & \multirow{2}{*}{\multicolumn{3}{|c|}{$\begin{array}{c}\text { Modelo estimado': } y=-29,08+1,60 X_{2}-1,94 X_{12}- \\
-1,22 X_{19}-0,94 X_{27}-0,84 X_{29}-1,31 X_{52}+0,81 X_{59}+ \\
+1,99 X_{74}+1,39 X_{87}+1,44 X_{89}+1,37 X_{92}+1,16 X_{94}+ \\
+1,54 X_{102}-1,09 X_{104}-1,11 X_{109}+1,98 X_{119}\end{array}$}} \\
\hline Total & 799 & - & & & \\
\hline
\end{tabular}

CRUZAMENTO 5

\begin{tabular}{lrr}
\hline CV & GL & \multicolumn{1}{c}{ QM } \\
\hline Progênie & $(399)$ & 95,5136 \\
Regressão & 15 & 901,4229 \\
Desvio & 384 & 64,0328 \\
Erro & 400 & 69,3450 \\
\hline Total & 799 & \multicolumn{1}{c}{-} \\
\hline
\end{tabular}

\begin{tabular}{|c|c|c|}
\hline $\mathrm{H}^{2}$ & & $R^{2}$ \\
\hline 0,274 & & 355 \\
\hline$\hat{\mathrm{p}}$ & $r$ & $b_{M}$ \\
\hline 1,20 & 0,813 & $-13,05$ \\
\hline \multicolumn{3}{|c|}{$\begin{array}{c}\text { Modelo estimado': } y=-25,80-2,20 X_{11}+2,09 X_{21}+ \\
+2,13 X_{46}-1,65 X_{51}-1,93 X_{71}+1,60 X_{74}+1,19 X_{79}+ \\
+1,57 X_{81}-0,94 X_{89}-1,64 X_{94}-0,92 X_{96}- \\
-0,85 X_{106}+1,40 X_{119}+0,97 X_{126}+1,48 X_{129} \\
\end{array}$} \\
\hline
\end{tabular}

1. $x_{j}$ : número de cópias de um dos alelos do loco marcador de posição j no genoma simulado da Figura 1. 


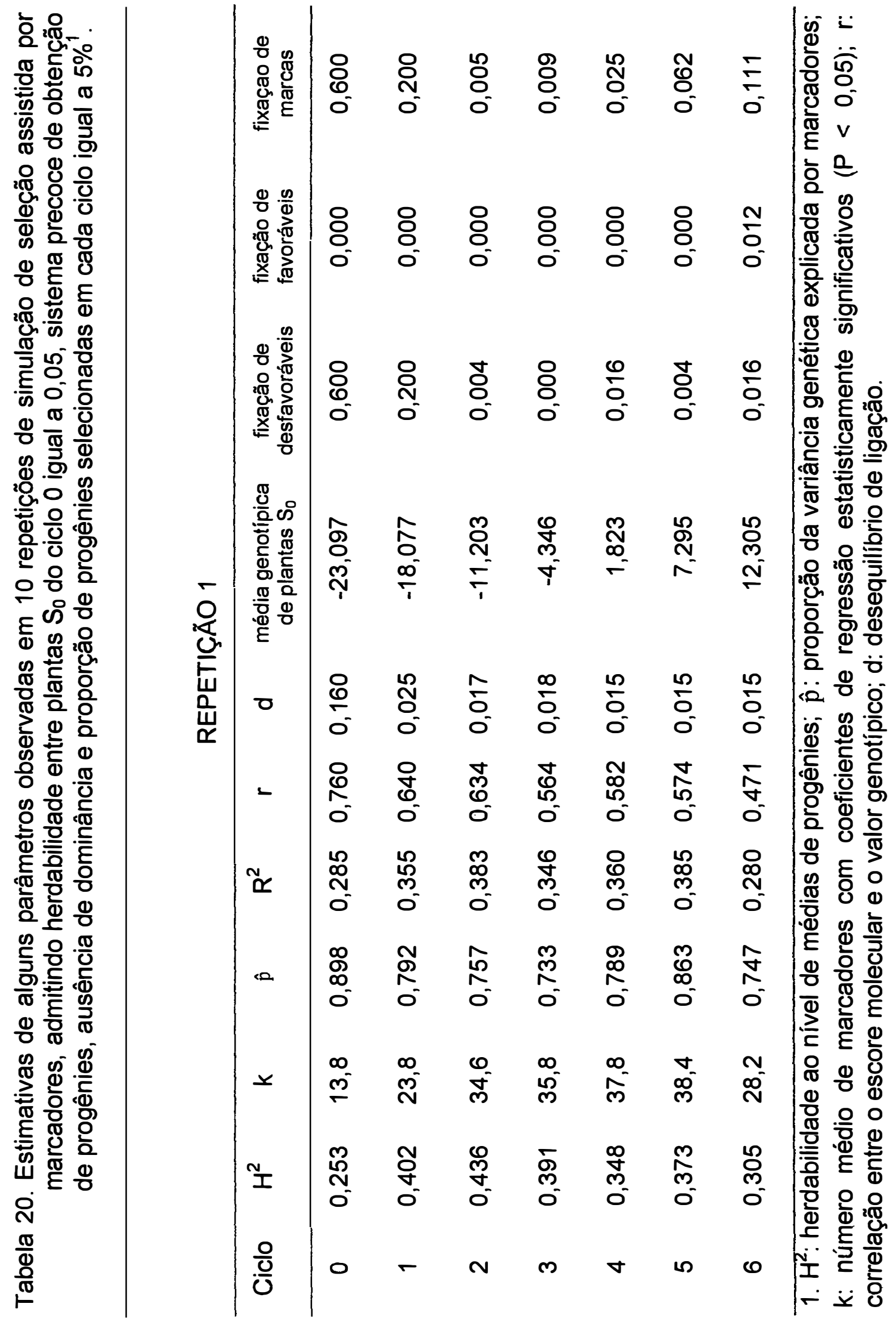




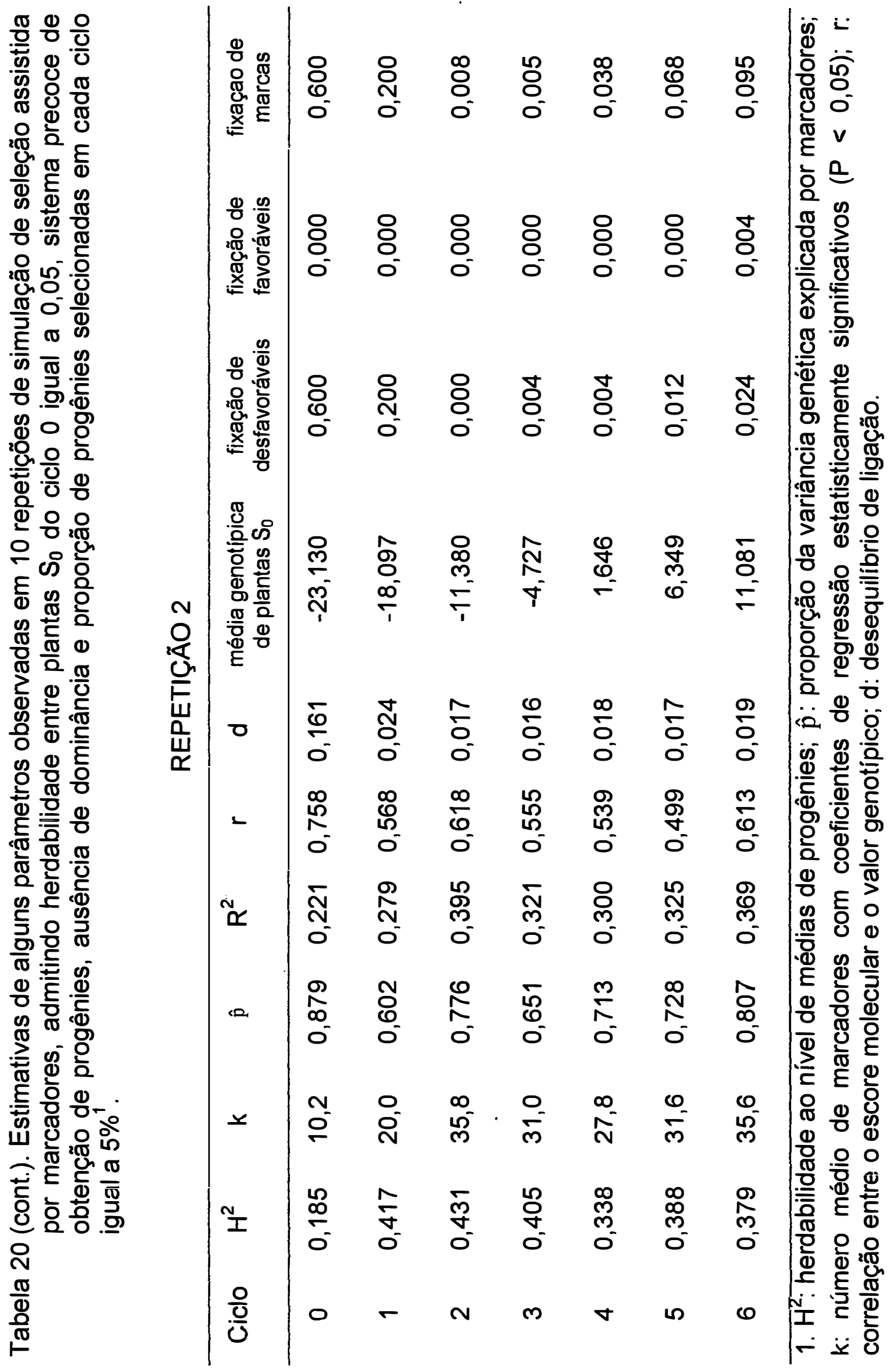




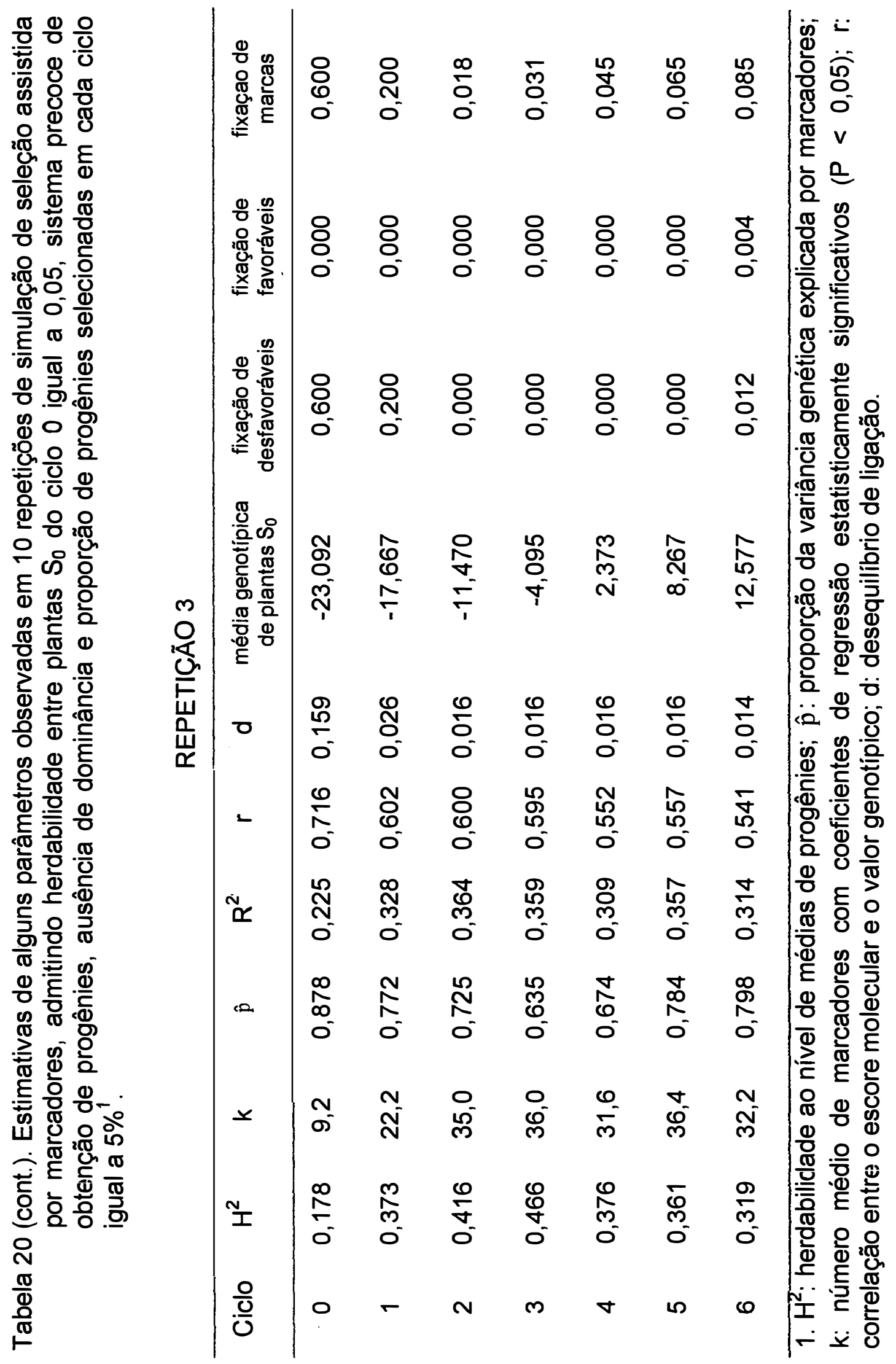




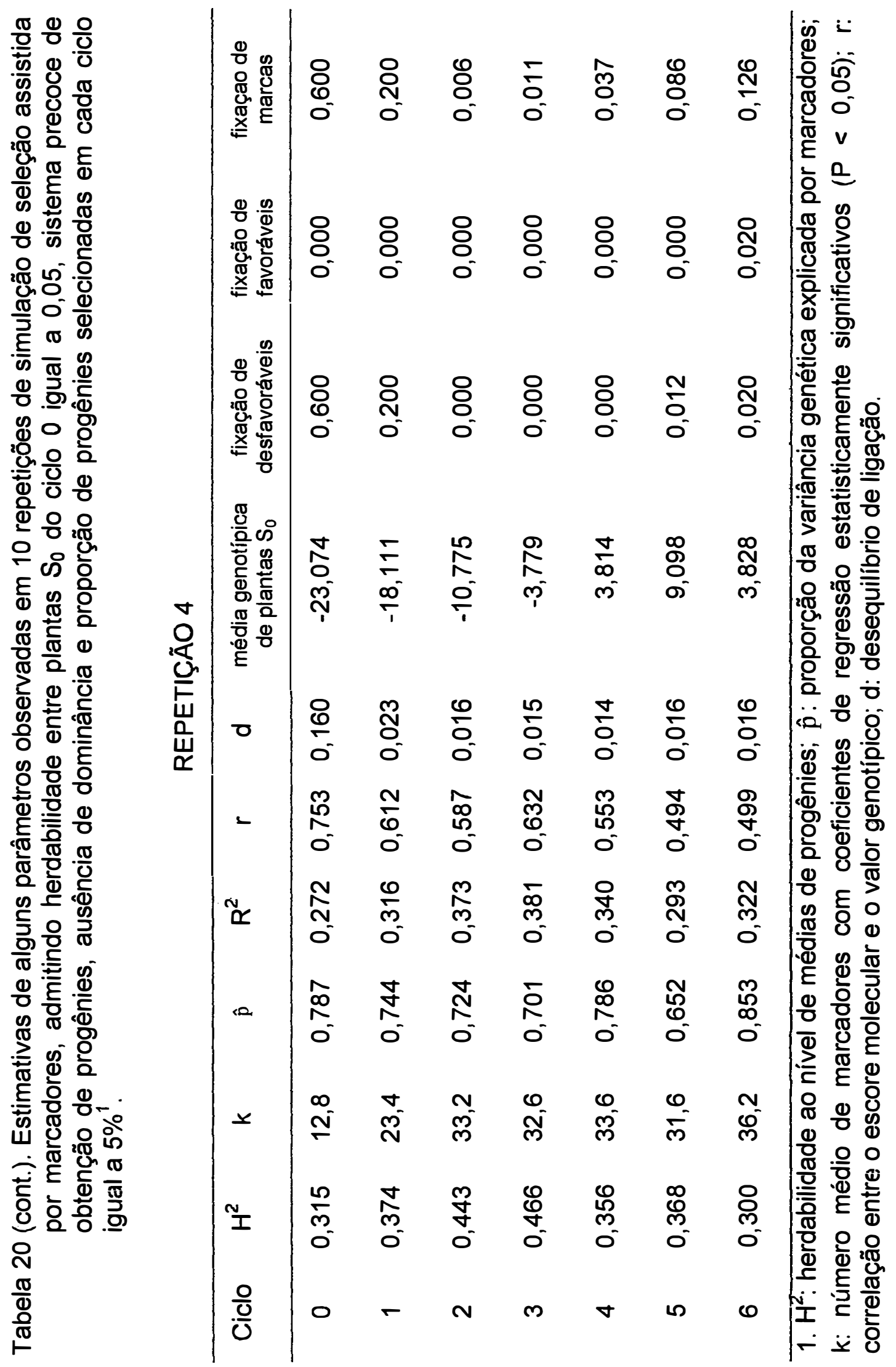




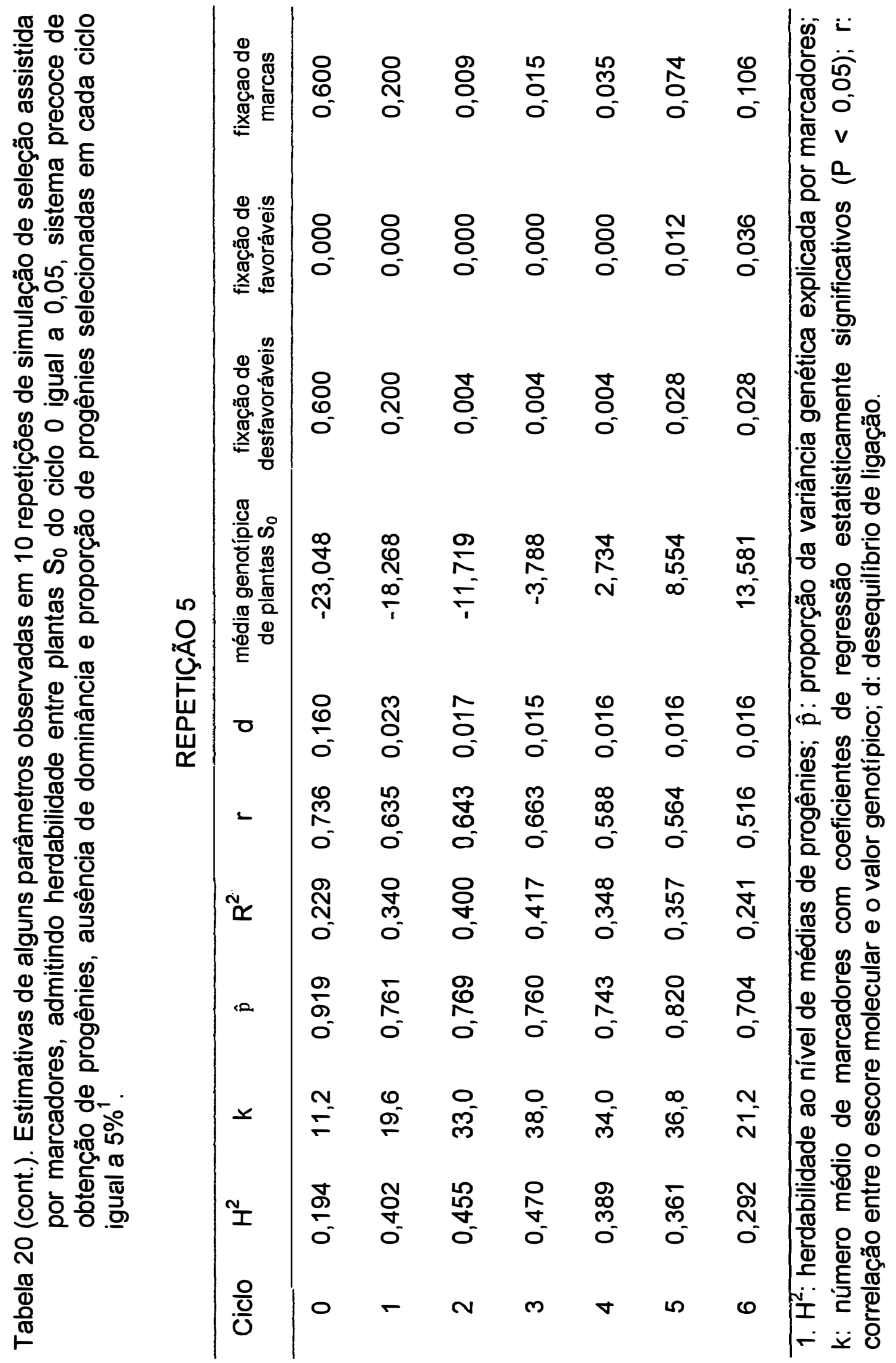




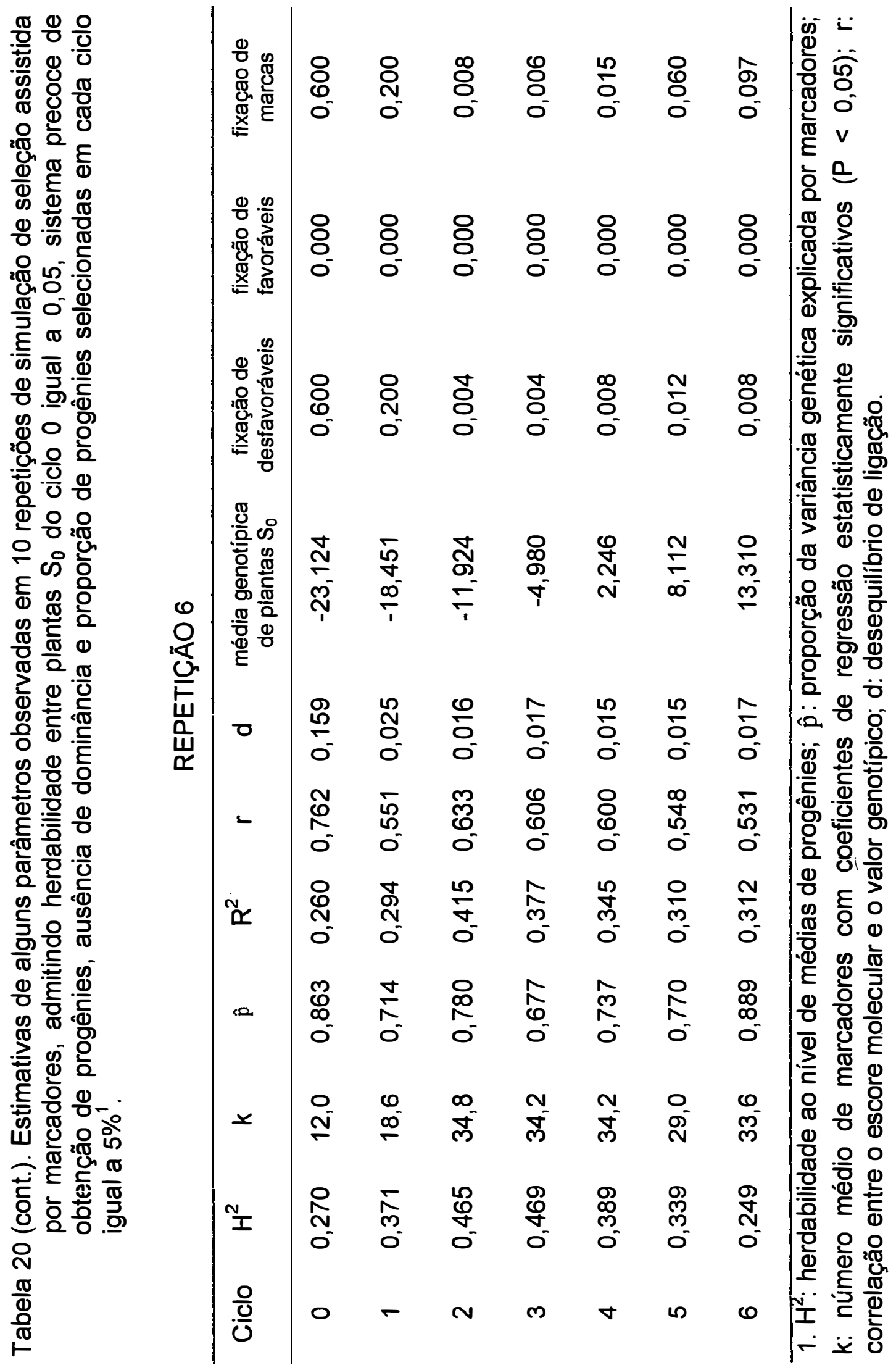




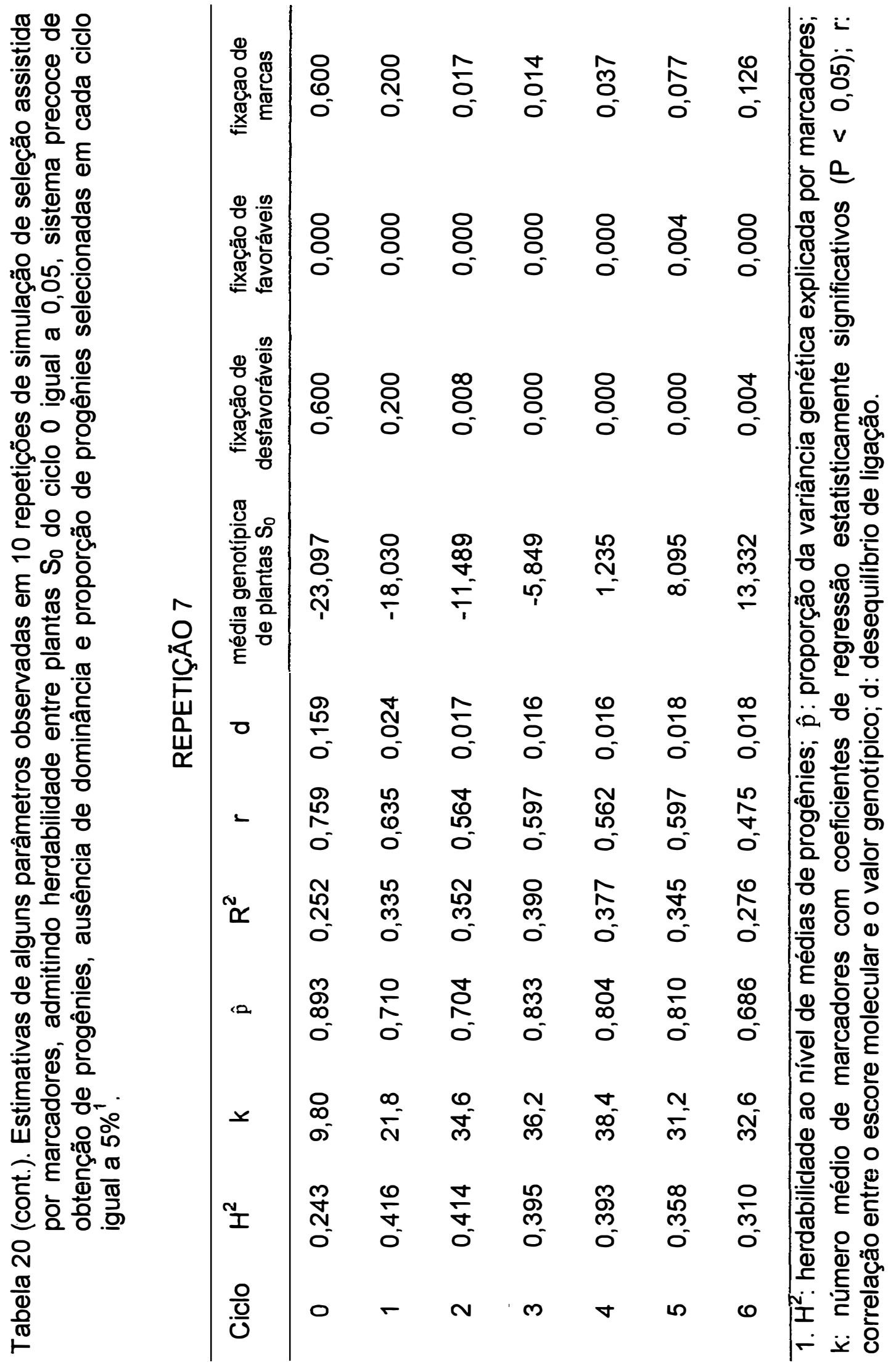


은 응 은

D

\%

ฮิ

20

ब

⿷

(1) .⿹勹口

- 음

$2 \pi 0$

(1) 0

है

क ত

흥.므용

\&0

엄음

흥

힝응 잉

응ํㄴㅎㅐ

응

क 눙

중

(ब)

원

完

О

융 응

क

중

क

증

도

5 응

ब。

응

क क

(5)

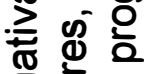

틍흥형

क

山 은

元

苍衣黄

임

$\frac{\pi}{0}$
焉

希

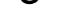

ฮ

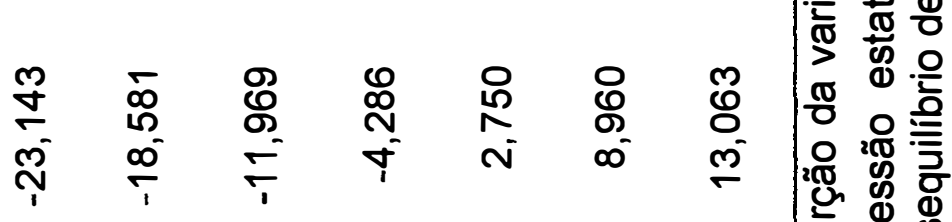

융

형

un

崖

$\begin{array}{llllllll}0 & 0 & 0 & 0 & \infty & \infty & \cdots & 0\end{array}$

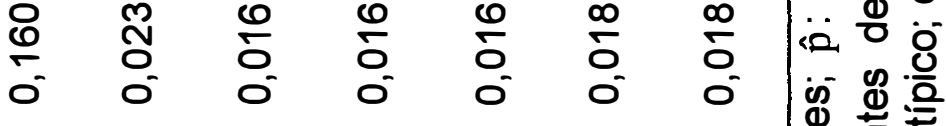

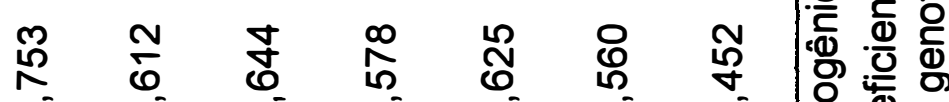

- $\begin{array}{lllllll}\kappa & 6 & 0 & 0 & 0 & 0 & 0 \\ 0 & 0 & 0 & 0 & 0 & 0 & 0\end{array}$

סे

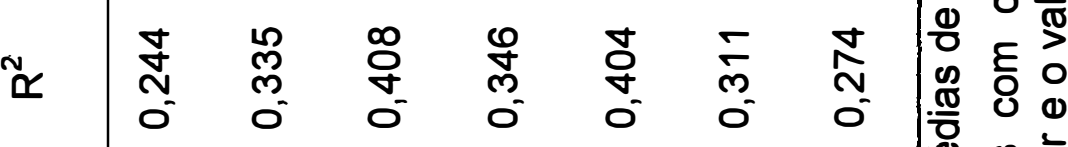

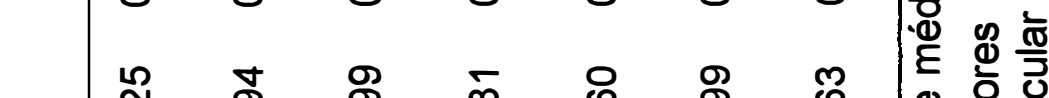

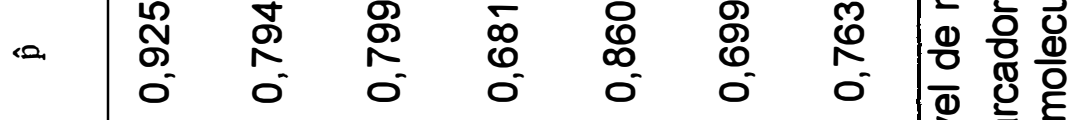

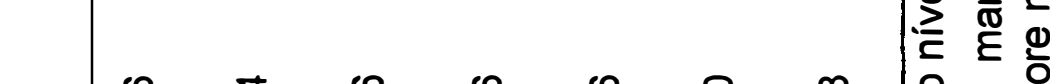

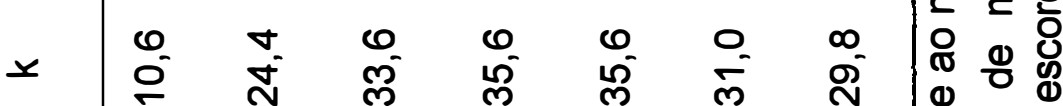

(1)

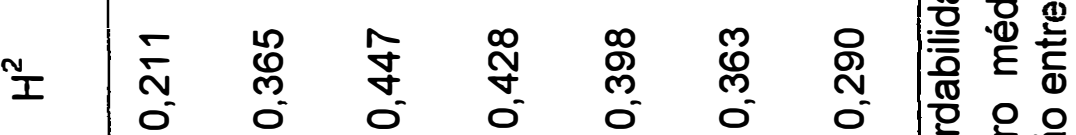

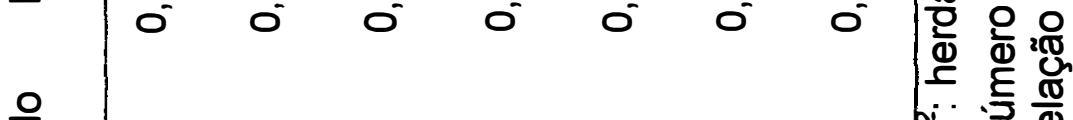

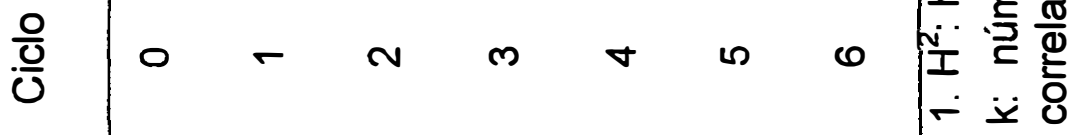




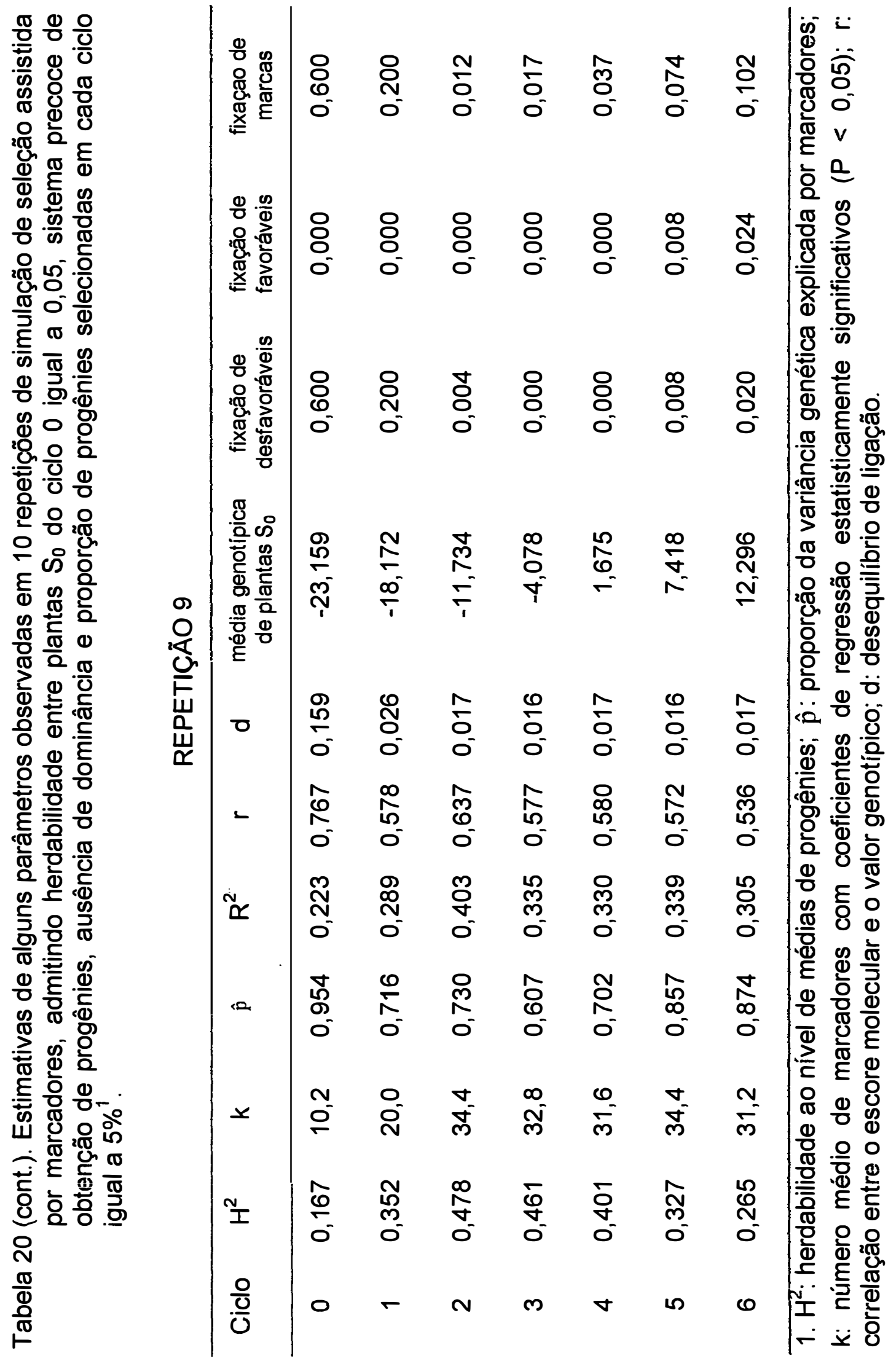




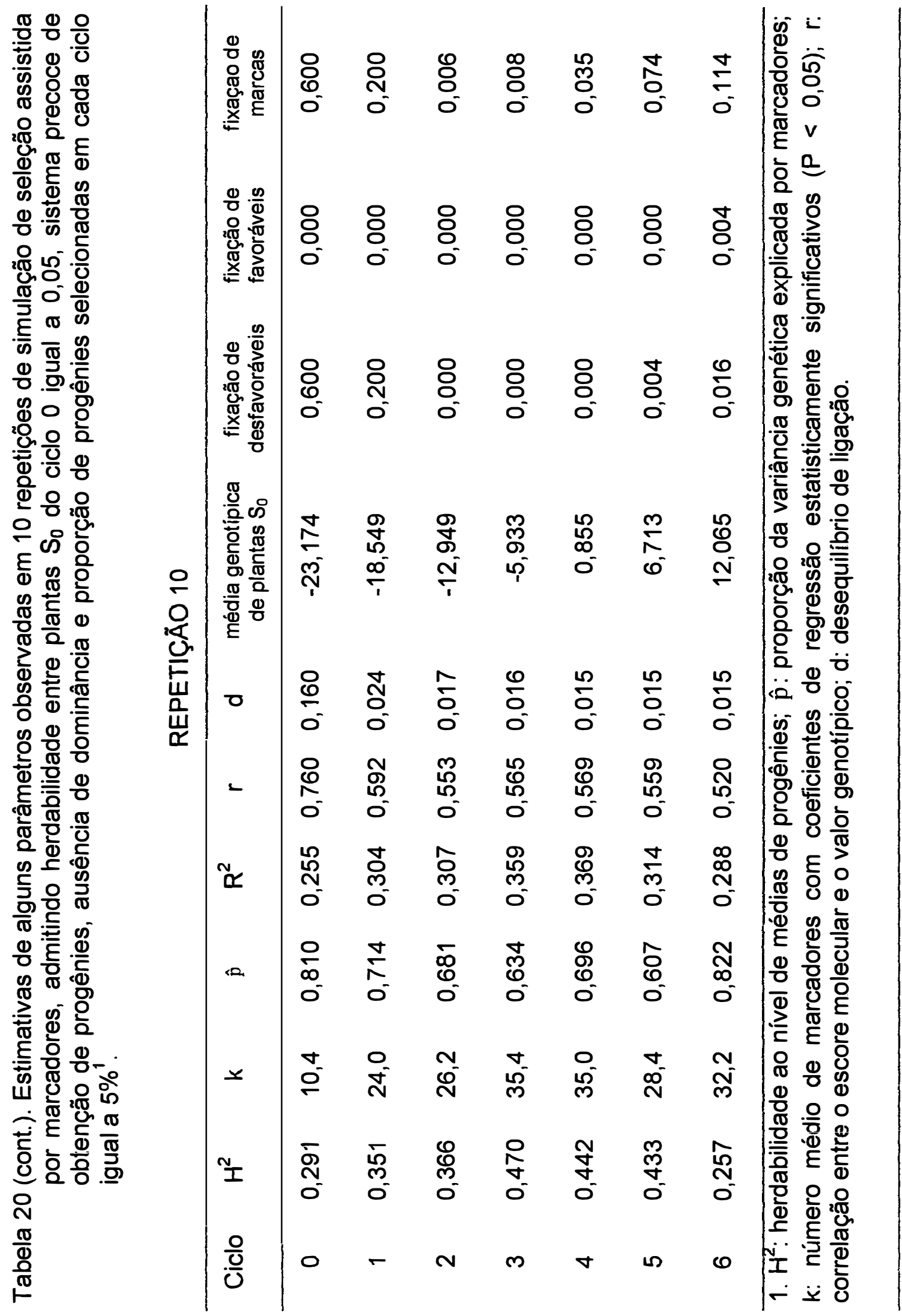


Tabela 21. Estimativas de alguns parâmetros observadas em 10 repetições de simulação de seleção baseada na média fenotípica de progênies, admitindo herdabilidade entre plantas $S_{0}$ do ciclo 0 igual a 0,05 , sistema precoce de obtenção de progênies, ausência de dominância e proporção de progênies selecionadas em cada ciclo igual a $5 \%{ }^{1}$.

REPETIÇÃO 1

\begin{tabular}{ccc} 
Ciclo & $\begin{array}{r}\text { média genotípica } \\
\text { de plantas } \mathrm{S}_{0}\end{array}$ & $\sqrt{\mathrm{H}^{2}}$ \\
\hline 0 & $-23,170$ & 0,451 \\
1 & $-20,212$ & 0,627 \\
2 & $-14,269$ & 0,675 \\
3 & $-7,437$ & 0,605 \\
4 & $-0,323$ & 0,676 \\
5 & 6,175 & 0,643 \\
6 & 11,835 & 0,527
\end{tabular}

REPETIÇÃO 2

\begin{tabular}{ccc}
\hline Ciclo & $\begin{array}{c}\text { média genotípica } \\
\text { de plantas } S_{0}\end{array}$ & $\sqrt{\mathrm{H}^{2}}$ \\
\hline 0 & $-23,063$ & 0,456 \\
1 & $-19,796$ & 0,640 \\
2 & $-13,341$ & 0,627 \\
3 & $-7,203$ & 0,634 \\
4 & $-0,254$ & 0,680 \\
5 & 6,038 & 0,581 \\
6 & 11,119 & 0,501
\end{tabular}

1. $\mathrm{H}^{2}$ : herdabilidade ao nível de médias de progênies. 
Tabela 21 (continuação). Estimativas de alguns parâmetros observadas em 10 repetições de simulação de seleção baseada na média fenotípica de progênies, admitindo herdabilidade entre plantas $S_{0}$ do ciclo 0 igual a 0,05 , sistema precoce de obtenção de progênies, ausência de dominância e proporção de progênies selecionadas em cada ciclo igual a $5 \%{ }^{1}$.

\section{REPETIÇÃO 3}

\begin{tabular}{ccc}
\hline Ciclo & $\begin{array}{c}\text { média genotípica } \\
\text { de plantas } S_{0}\end{array}$ & $\sqrt{\mathrm{H}^{2}}$ \\
\hline 0 & $-23,194$ & 0,502 \\
1 & $-20,272$ & 0,605 \\
2 & $-14,187$ & 0,622 \\
3 & $-7,240$ & 0,650 \\
4 & 0,377 & 0,586 \\
5 & 6,363 & 0,603 \\
6 & 11,916 & 0,526 \\
\hline
\end{tabular}

\section{REPETIÇÃO 4}

\begin{tabular}{ccc}
\hline Ciclo & $\begin{array}{c}\text { média genotípica } \\
\text { de plantas } \mathrm{S}_{0}\end{array}$ & $\sqrt{\mathrm{H}^{2}}$ \\
\hline 0 & $-23,108$ & 0,400 \\
1 & $-19,858$ & 0,602 \\
2 & $-13,501$ & 0,664 \\
3 & $-5,316$ & 0,694 \\
4 & 3,131 & 0,606 \\
5 & 9,405 & 0,591 \\
6 & 14,285 & 0,519 \\
\hline
\end{tabular}

1. $\mathrm{H}^{2}$ : herdabilidade ao nivel de médias de progênies. 
Tabela 21 (continuação). Estimativas de alguns parâmetros observadas em 10 repetições de simulação de seleção baseada na média fenotípica de progênies, admitindo herdabilidade entre plantas $S_{0}$ do ciclo 0 igual a 0,05 , sistema precoce de obtenção de progênies, ausência de dominância e proporção de progênies selecionadas em cada ciclo igual a $5 \%{ }^{1}$.

\section{REPETIÇÃO 5}

\begin{tabular}{ccc}
\hline Ciclo & $\begin{array}{c}\text { média genotípica } \\
\text { de plantas } \mathrm{S}_{0}\end{array}$ & $\sqrt{\mathrm{H}^{2}}$ \\
\hline 0 & $-23,169$ & 0,484 \\
1 & $-19,540$ & 0,625 \\
2 & $-13,995$ & 0,642 \\
3 & $-6,331$ & 0,641 \\
4 & 0,076 & 0,581 \\
5 & 6,147 & 0,548 \\
6 & 10,806 & 0,499 \\
\hline
\end{tabular}

\section{REPETIÇÃO 6}

\begin{tabular}{ccc}
\hline Ciclo & $\begin{array}{r}\text { média genotípica } \\
\text { de plantas } \mathrm{S}_{0}\end{array}$ & $\sqrt{\mathrm{H}^{2}}$ \\
\hline 0 & $-23,105$ & 0,543 \\
1 & $-19,739$ & 0,602 \\
2 & $-13,742$ & 0,693 \\
3 & $-6,677$ & 0,619 \\
4 & $-0,692$ & 0,633 \\
5 & 5,561 & 0,599 \\
6 & 10,659 & 0,553
\end{tabular}

1. $H^{2}$ : herdabilidade ao nível de médias de progênies. 
Tabela 21 (continuaçāo). Estimativas de alguns parâmetros observadas em 10 repetições de simulação de seleção baseada na média fenotípica de progênies, admitindo herdabilidade entre plantas $S_{0}$ do ciclo 0 igual a 0,05 , sistema precoce de obtenção de progênies, ausência de dominância e proporção de progênies selecionadas em cada ciclo igual a $5 \%{ }^{1}$.

\section{REPETIÇÃO 7}

\begin{tabular}{ccc}
\hline Ciclo & $\begin{array}{c}\text { média genotípica } \\
\text { de plantas } \mathrm{S}_{0}\end{array}$ & $\sqrt{\mathrm{H}^{2}}$ \\
\hline 0 & $-23,182$ & 0,479 \\
1 & $-19,252$ & 0,643 \\
2 & $-12,627$ & 0,662 \\
3 & $-5,254$ & 0,659 \\
4 & 1,902 & 0,656 \\
5 & 8,397 & 0,578 \\
6 & 13,676 & 0,581 \\
\hline
\end{tabular}

REPETIÇÃO 8

\begin{tabular}{ccc}
\hline Ciclo & $\begin{array}{c}\text { média genotípica } \\
\text { de plantas So }\end{array}$ & $\sqrt{\mathrm{H}^{2}}$ \\
\hline 0 & $-23,019$ & 0,503 \\
1 & $-19,517$ & 0,583 \\
2 & $-13,420$ & 0,638 \\
3 & $-6,416$ & 0,642 \\
4 & $-0,349$ & 0,616 \\
5 & 4,967 & 0,568 \\
6 & 9,856 & 0,581 \\
\hline
\end{tabular}

1. $\mathrm{H}^{2}$ : herdabilidade ao nível de médias de progênies. 
Tabela 21 (continuação). Estimativas de alguns parâmetros observadas em 10 repetições de simulação de seleção baseada na média fenotípica de progênies, admitindo herdabilidade entre plantas $S_{0}$ do ciclo 0 igual a 0,05 , sistema precoce de obtenção de progênies, ausência de dominância e proporção de progênies selecionadas em cada ciclo igual a $5 \%{ }^{1}$.

\section{REPETIÇÃO 9}

\begin{tabular}{|c|c|c|}
\hline Ciclo & $\begin{array}{c}\text { média genotípica } \\
\text { de plantas } S_{0}\end{array}$ & $\sqrt{\mathrm{H}^{2}}$ \\
\hline 0 & $-23,066$ & 0,479 \\
\hline 1 & $-20,007$ & 0,583 \\
\hline 2 & $-14,287$ & 0,683 \\
\hline 3 & $-6,588$ & 0,647 \\
\hline 4 & 0,304 & 0,567 \\
\hline 5 & 5,910 & 0,583 \\
\hline 6 & 11,040 & 0,575 \\
\hline \multicolumn{3}{|c|}{ REPETIÇÃO 10} \\
\hline Ciclo & $\begin{array}{c}\text { média genotípica } \\
\text { de plantas } S_{0}\end{array}$ & $\sqrt{\mathrm{H}^{2}}$ \\
\hline 0 & $-23,110$ & 0,542 \\
\hline 1 & $-20,045$ & 0,586 \\
\hline 2 & $-13,980$ & 0,640 \\
\hline 3 & $-7,227$ & 0,660 \\
\hline 4 & $-0,755$ & 0,650 \\
\hline 5 & 5,419 & 0,594 \\
\hline 6 & 10,192 & 0,525 \\
\hline
\end{tabular}

1. $H^{2}$ : herdabilidade ao nivel de médias de progênies. 


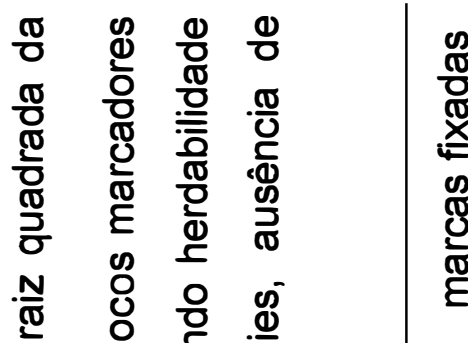

চิ

- 0 c o c o o o

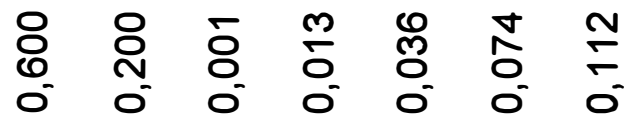

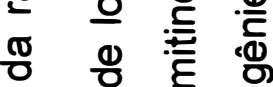

Е 0 व

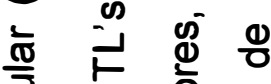

ป

ह

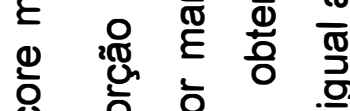

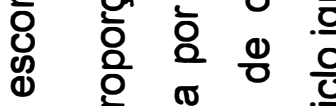

$\circ$ 흔 응 은

(1) 중

○) 0 \begin{tabular}{lll}
0 & 0 & 0 \\
\hline
\end{tabular}

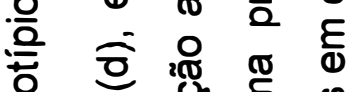

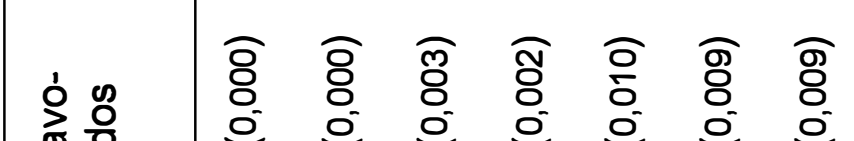

$\frac{\pi}{0} \frac{\pi}{0}$

希

is $\frac{0}{9}$

은

๑

ष

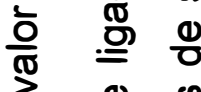

0 व

离

유

冚

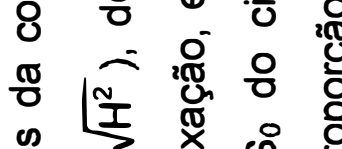

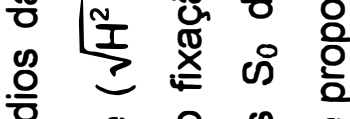

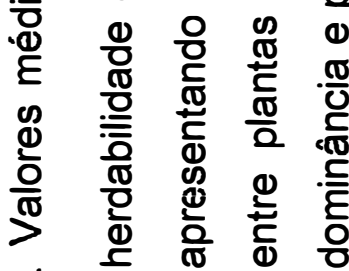

กิ

ता

$\frac{\pi}{0}$

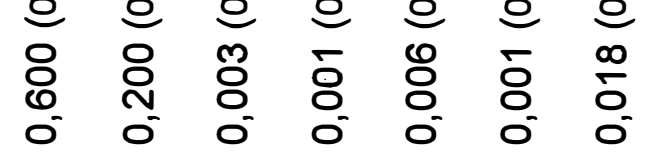

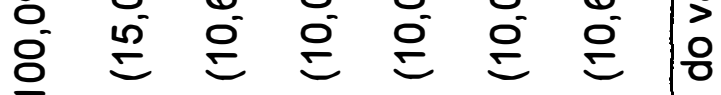

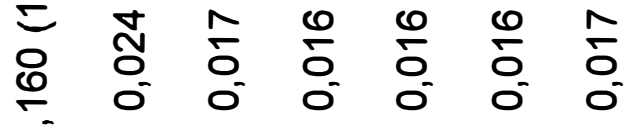

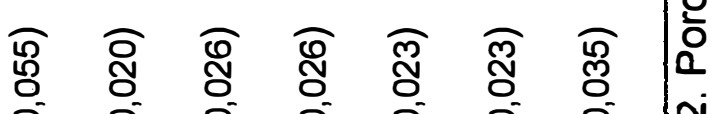

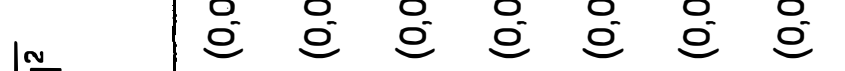

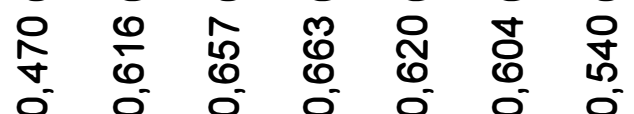

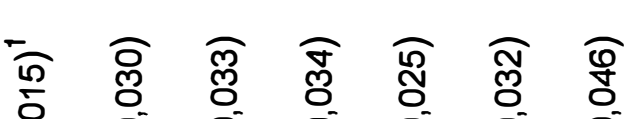

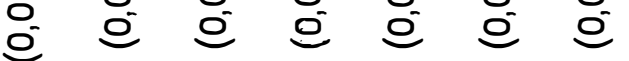

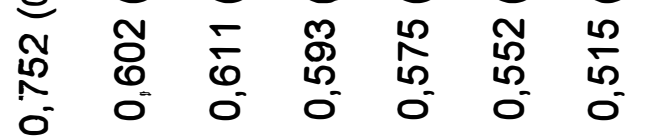

$\frac{0}{\frac{0}{0}} \mid 0-4$ a 2 a 


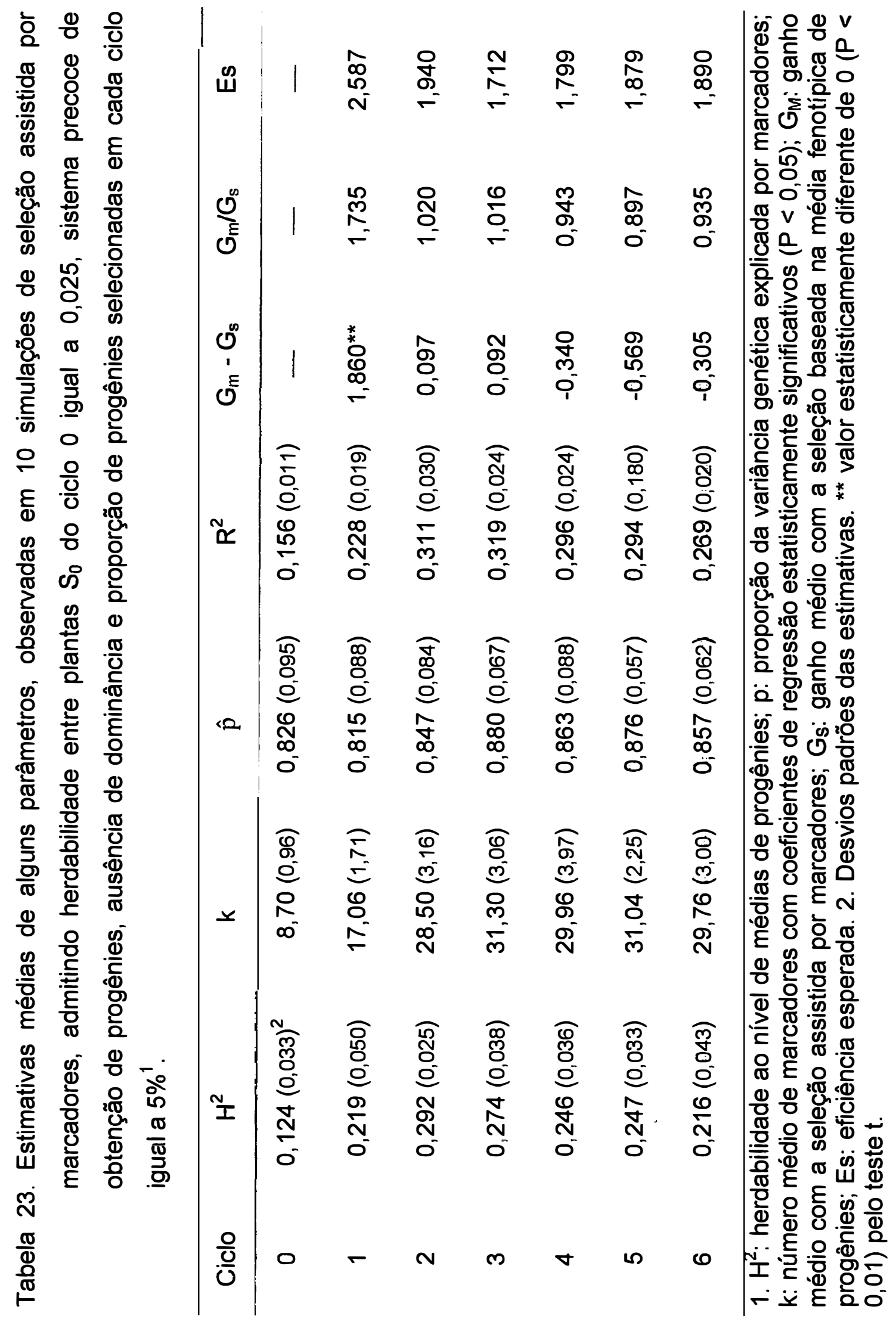




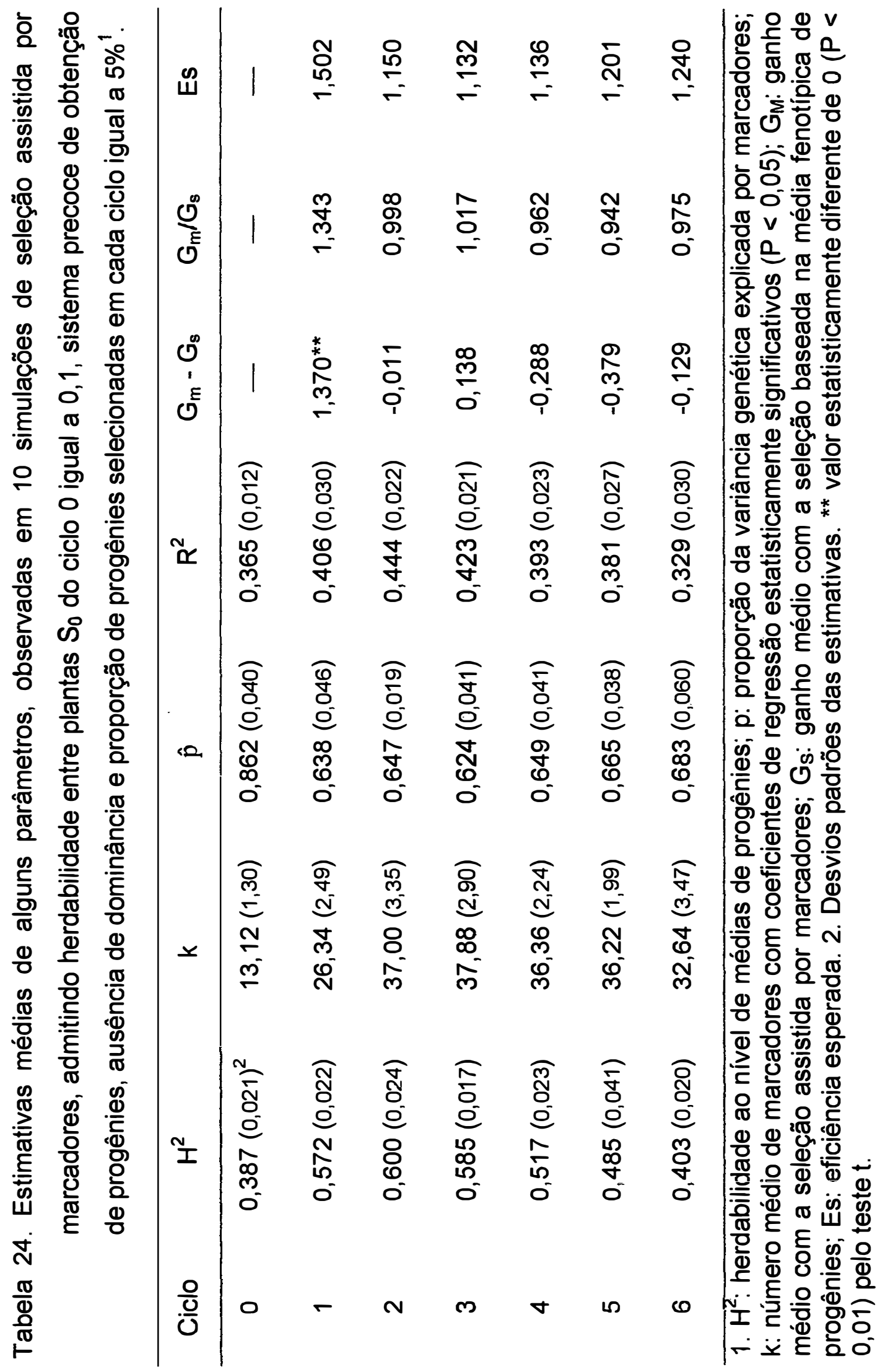




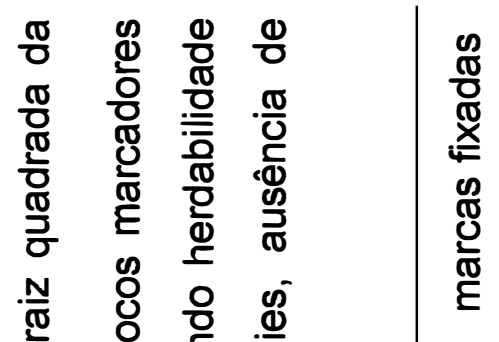

ฮิ

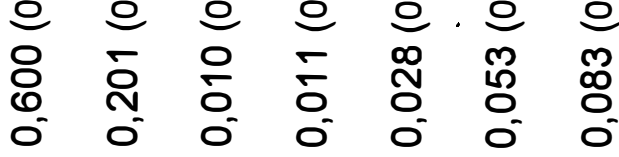

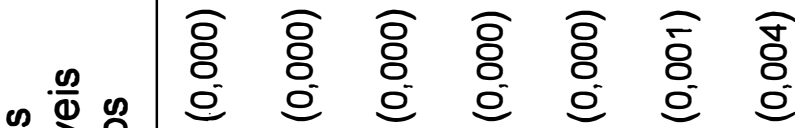
今 0 \%

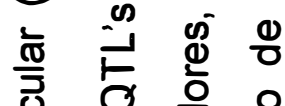

ర

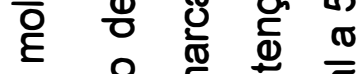

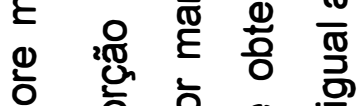

엃 흥 흥

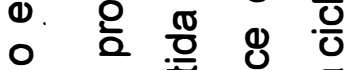

- $\frac{\pi}{0}$.

O)

을

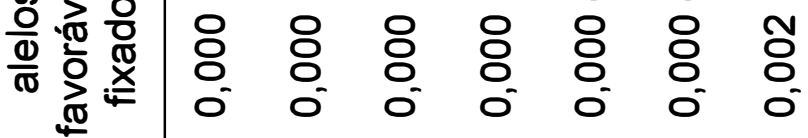

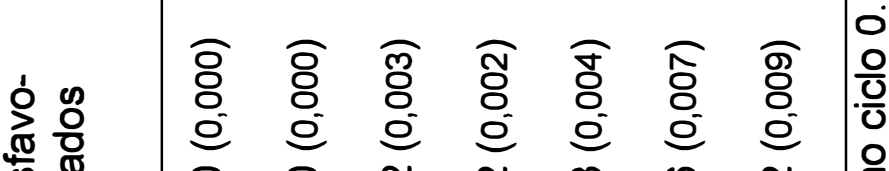

苞

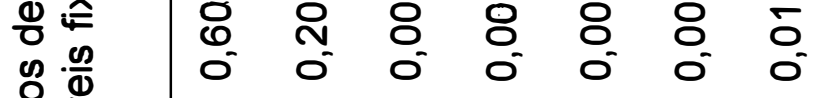

$\frac{0}{\mathbb{0}} \cdot \frac{\pi}{\mathbb{N}}$

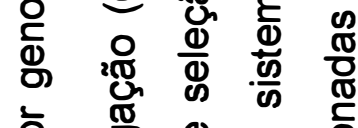

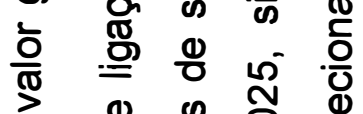

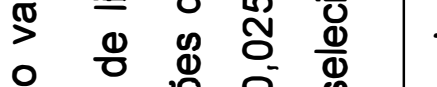

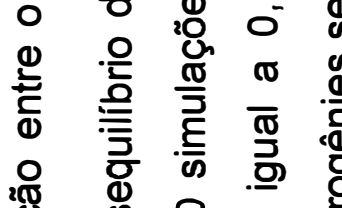

엥 Ð

인

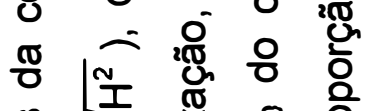

$\stackrel{\frac{n}{5}}{3}$

을 i

잉 웅

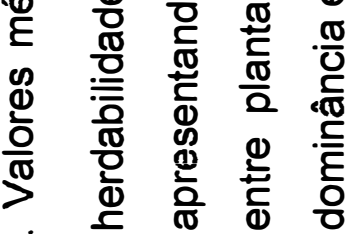

ผ

$\frac{\pi}{0}$

ㅇํㅇ वे

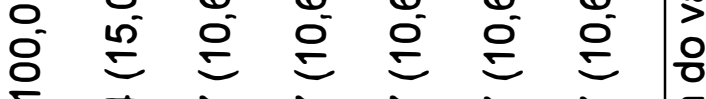

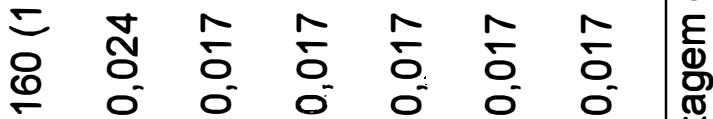

$\begin{array}{lllllll}- & 0 & 0 & 0 & 0 & 0 & 0\end{array}$

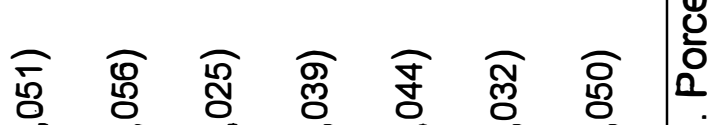

¿ c c c c c c c

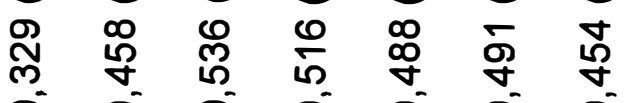

$\begin{array}{lllllll}0 & 0 & 0 & 0 & 0 & 0 & 0\end{array}$

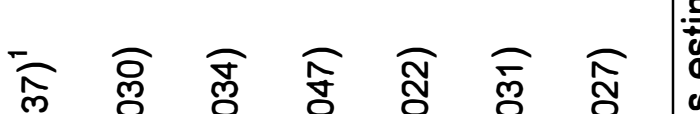

वे

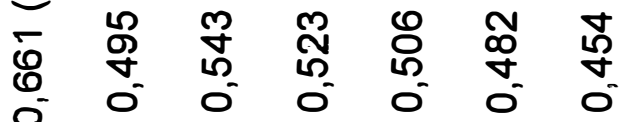

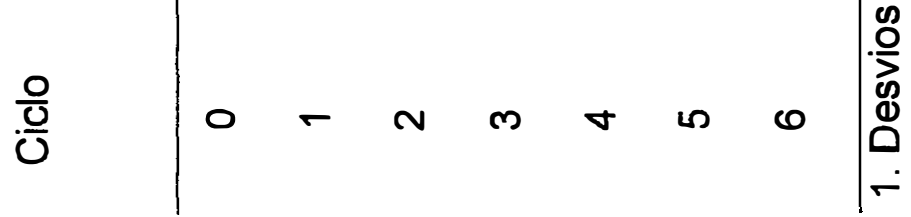




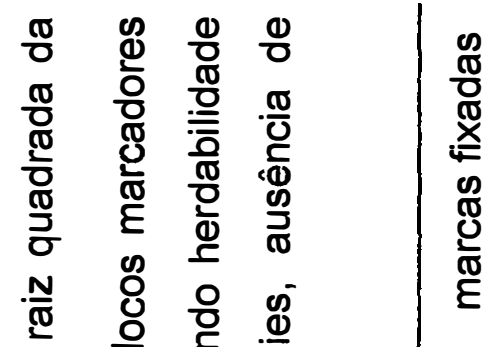
इ 0 \% 克 节

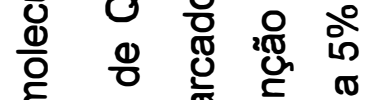

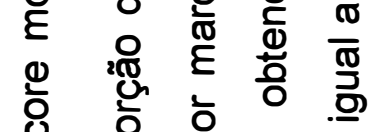
잉 - T 유 응 0 ฮ 음 응 웡 ป

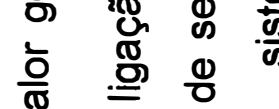
$>\quad 0 \quad 0=\frac{0}{0}$ ○ 0 竞 글

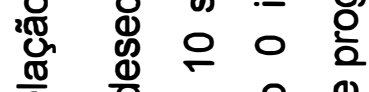

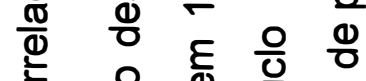

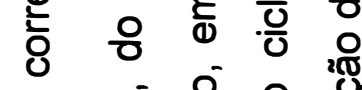

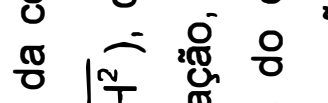

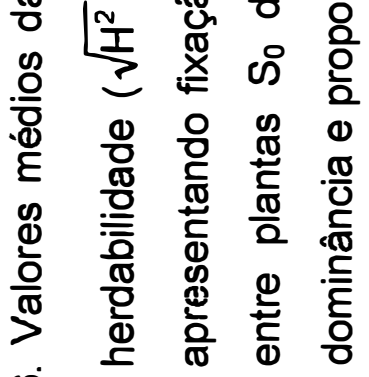
ì

$\frac{\pi}{0}$

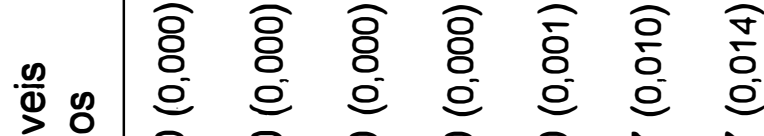

ठิ

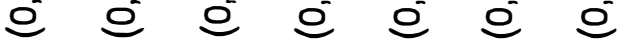

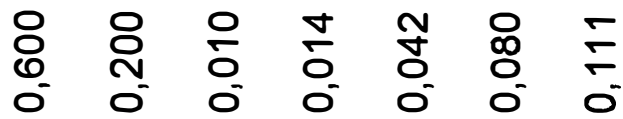

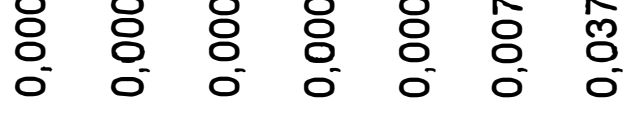
世 $\begin{array}{lllllll}0 & 0 & 0 & 0 & 0 & 0 & 0\end{array}$

웡 \&ิ $\frac{\mathscr{D}}{\mathbb{1}}$ $\frac{0}{\mathbb{0}} \cdot \frac{\pi}{\mathbb{N}}$

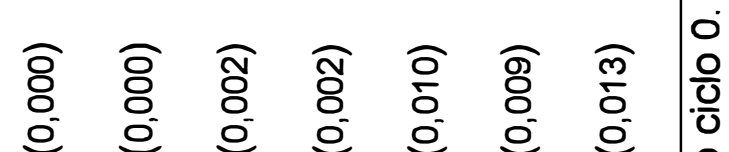

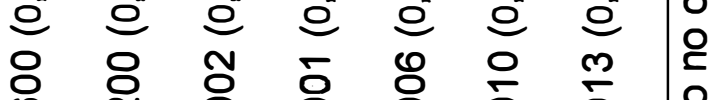

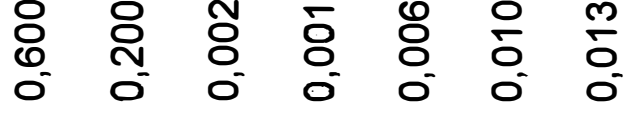
咅 咅 o v ปั 等 0 勇

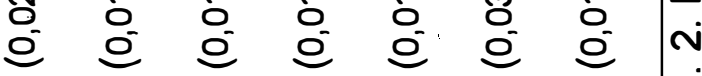
然

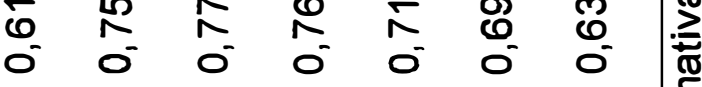

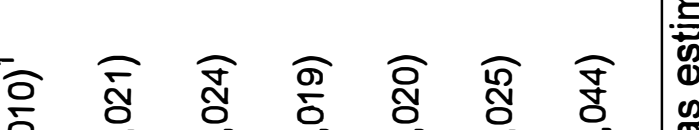

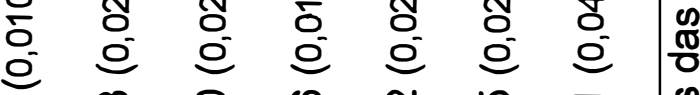

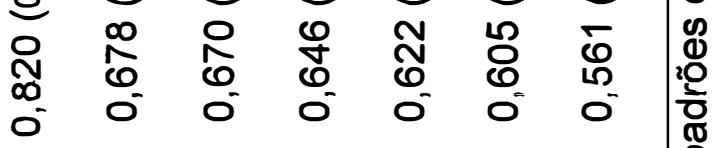

$0-a \sin 0$ 


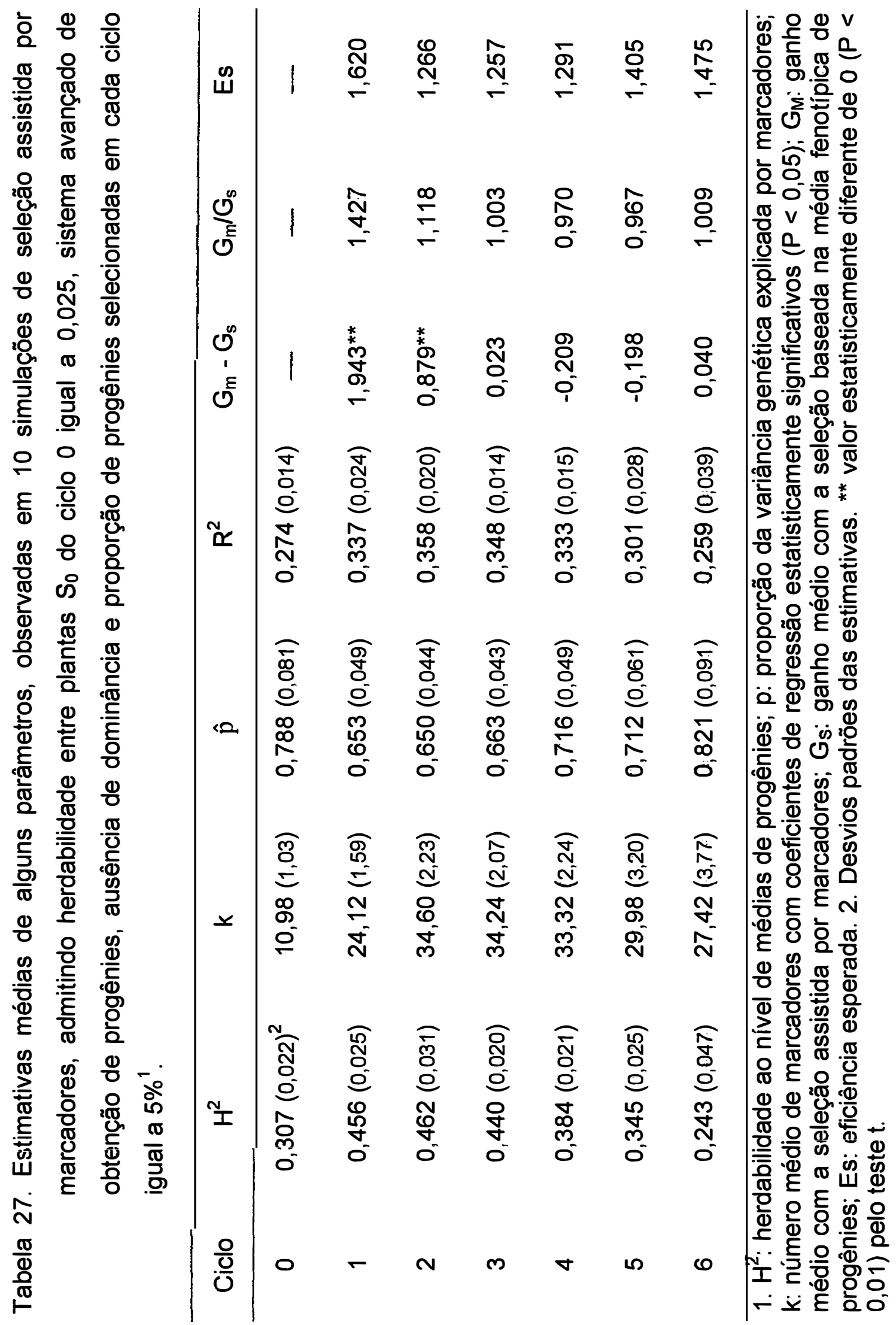




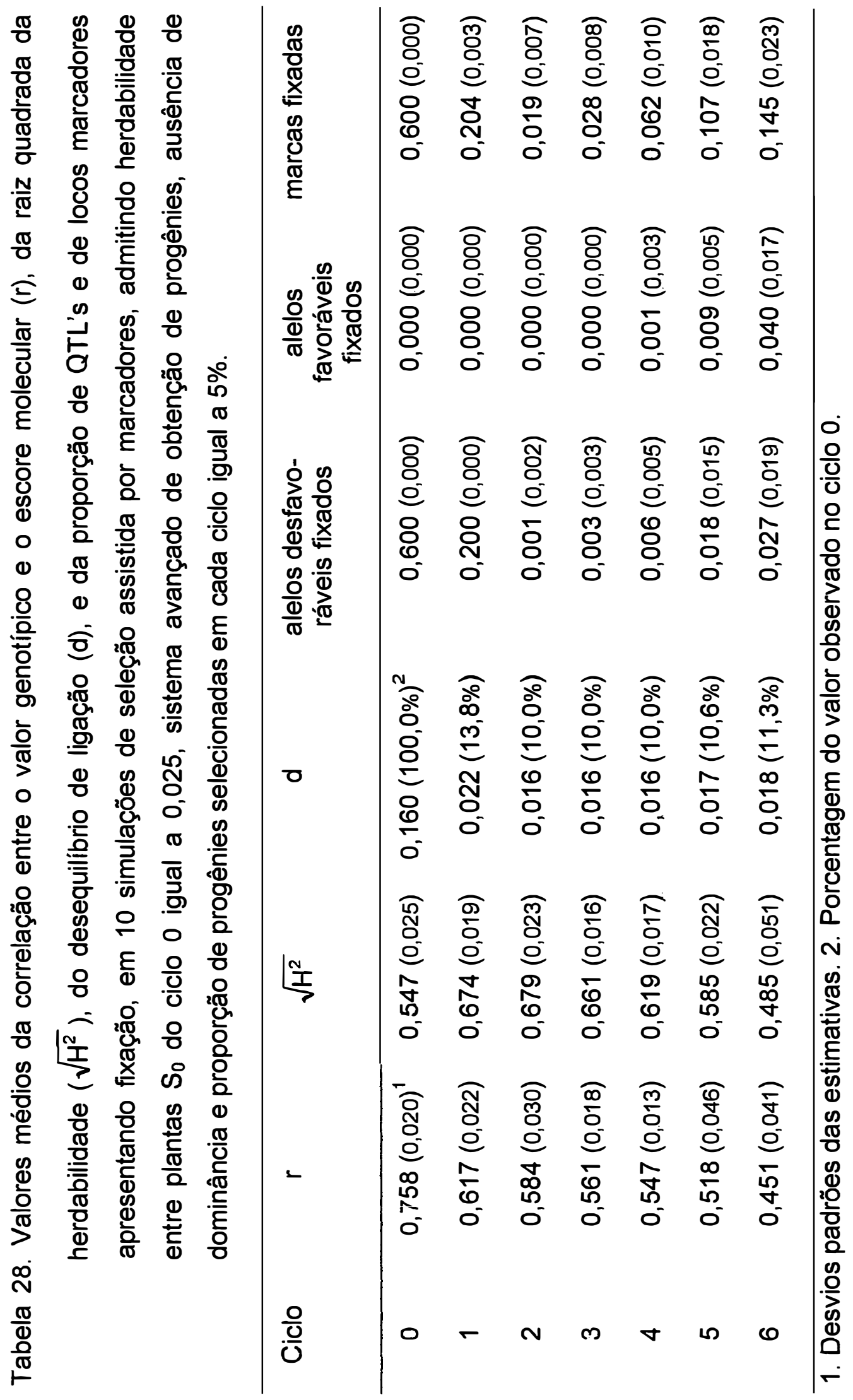




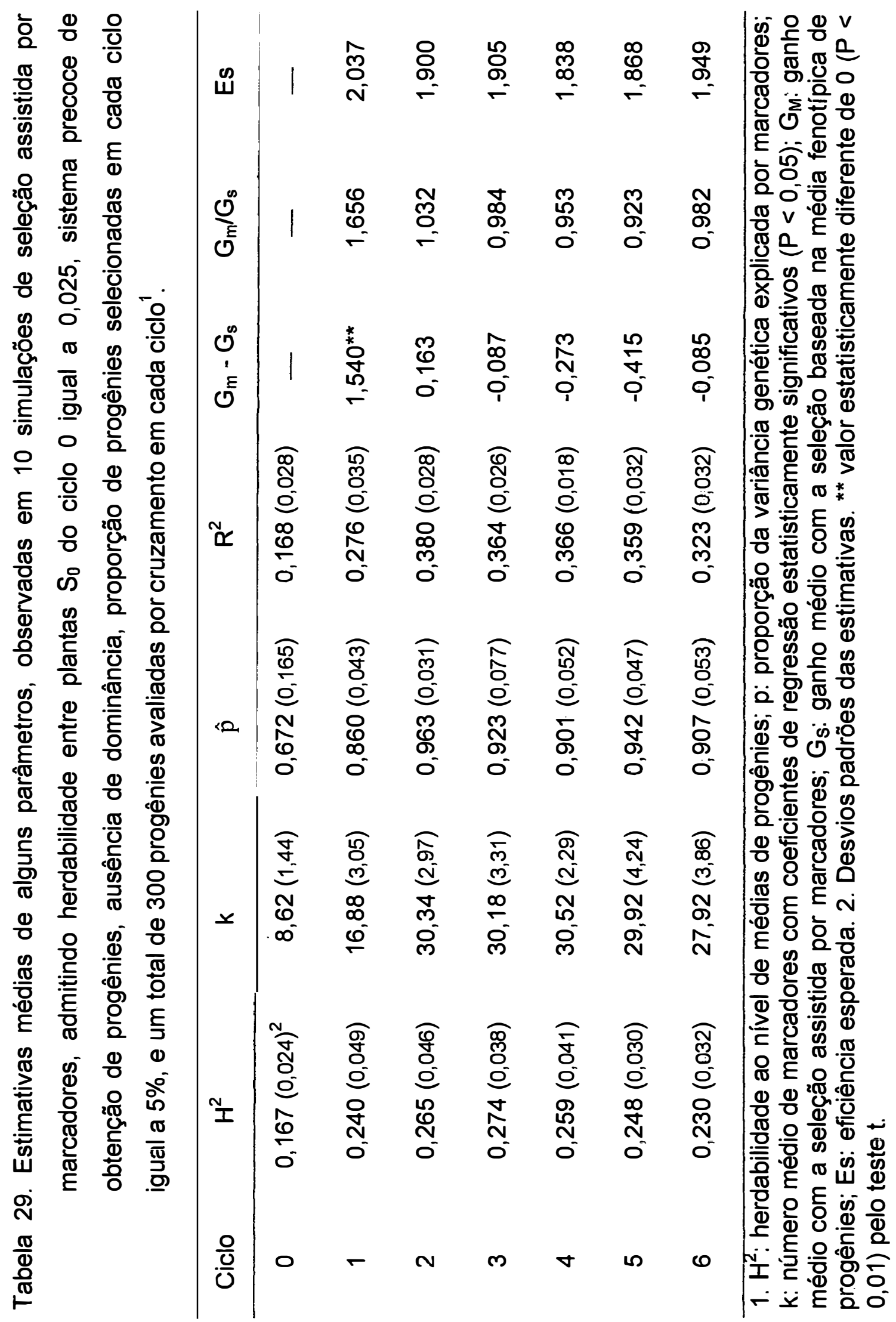




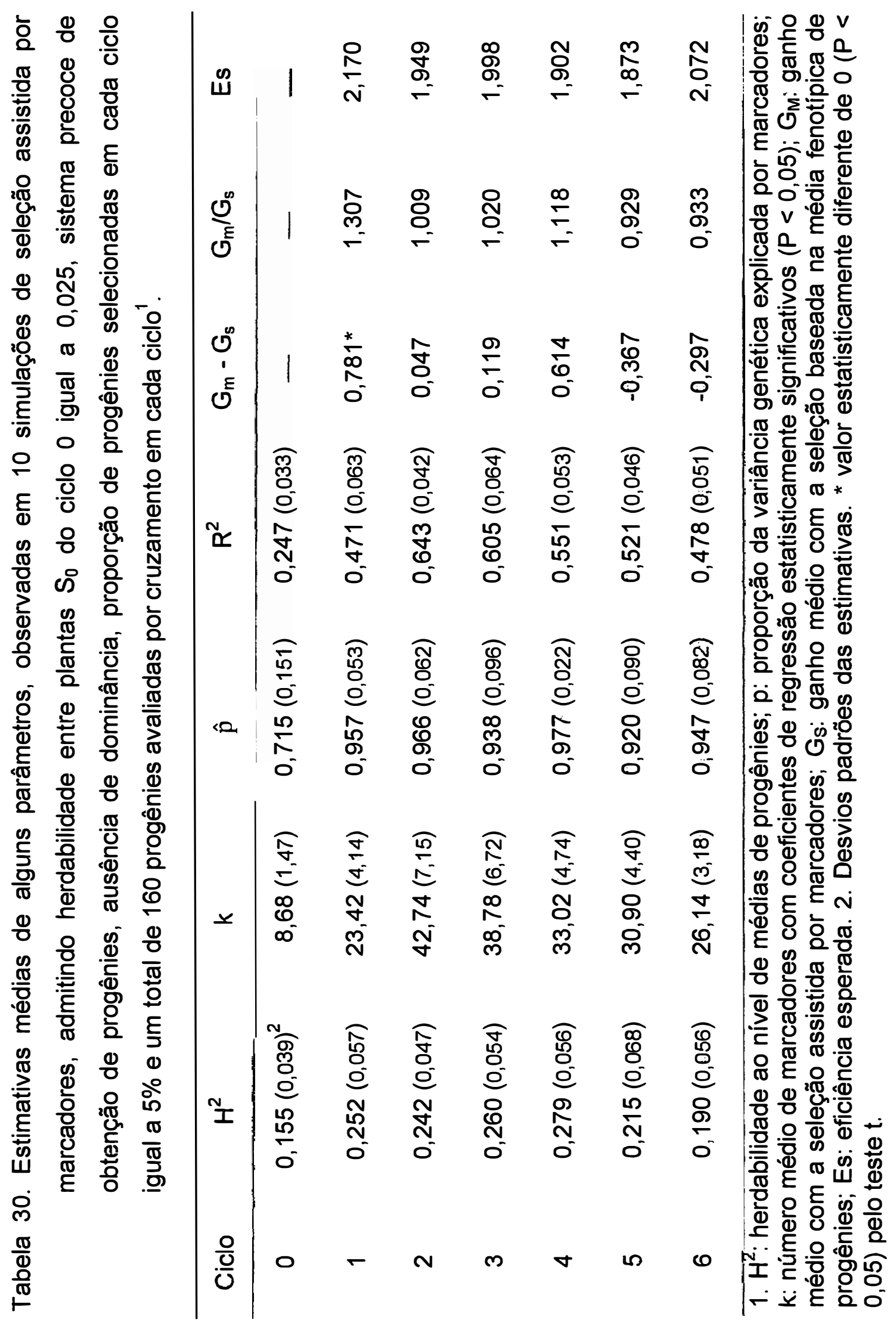




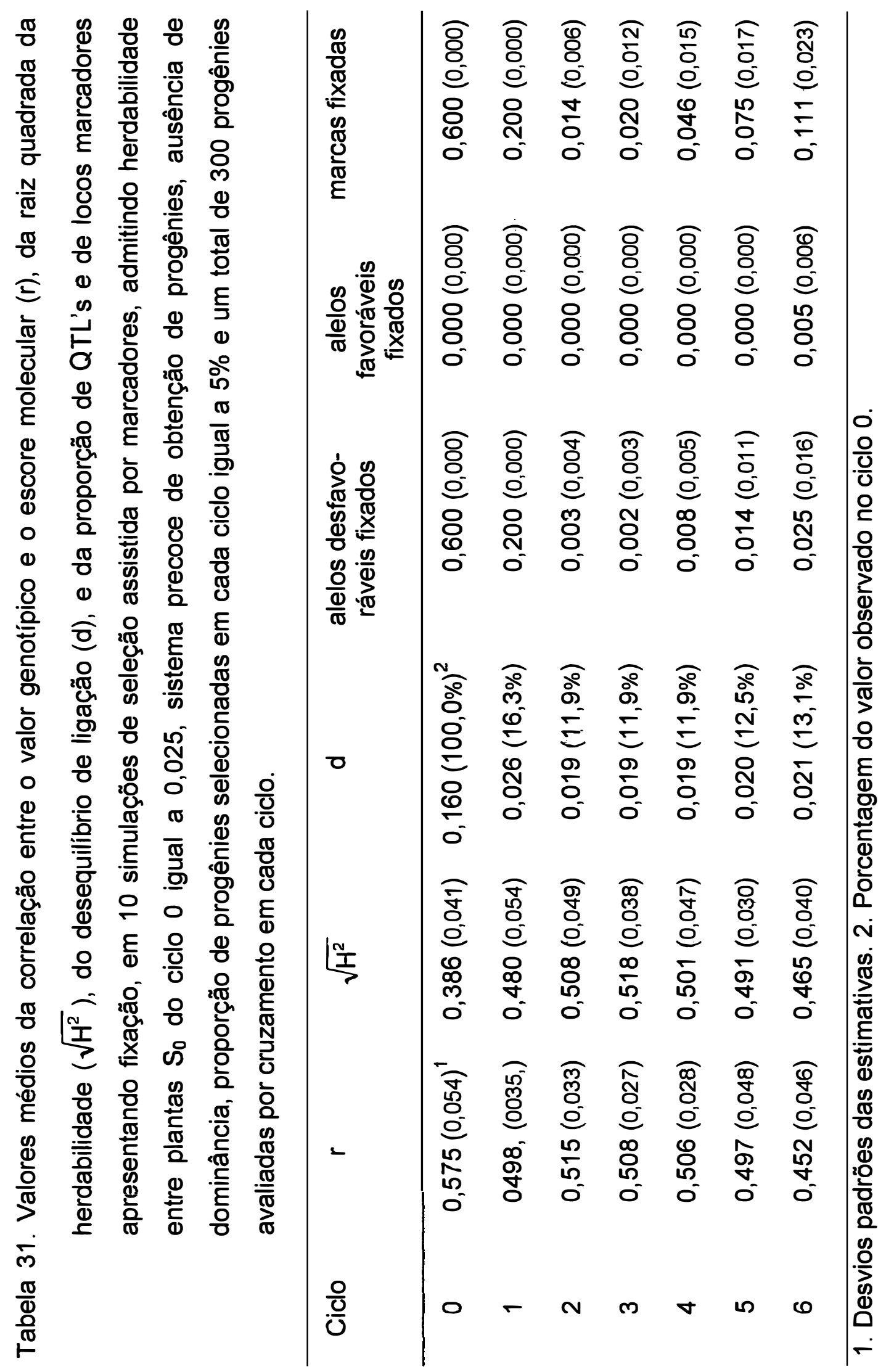




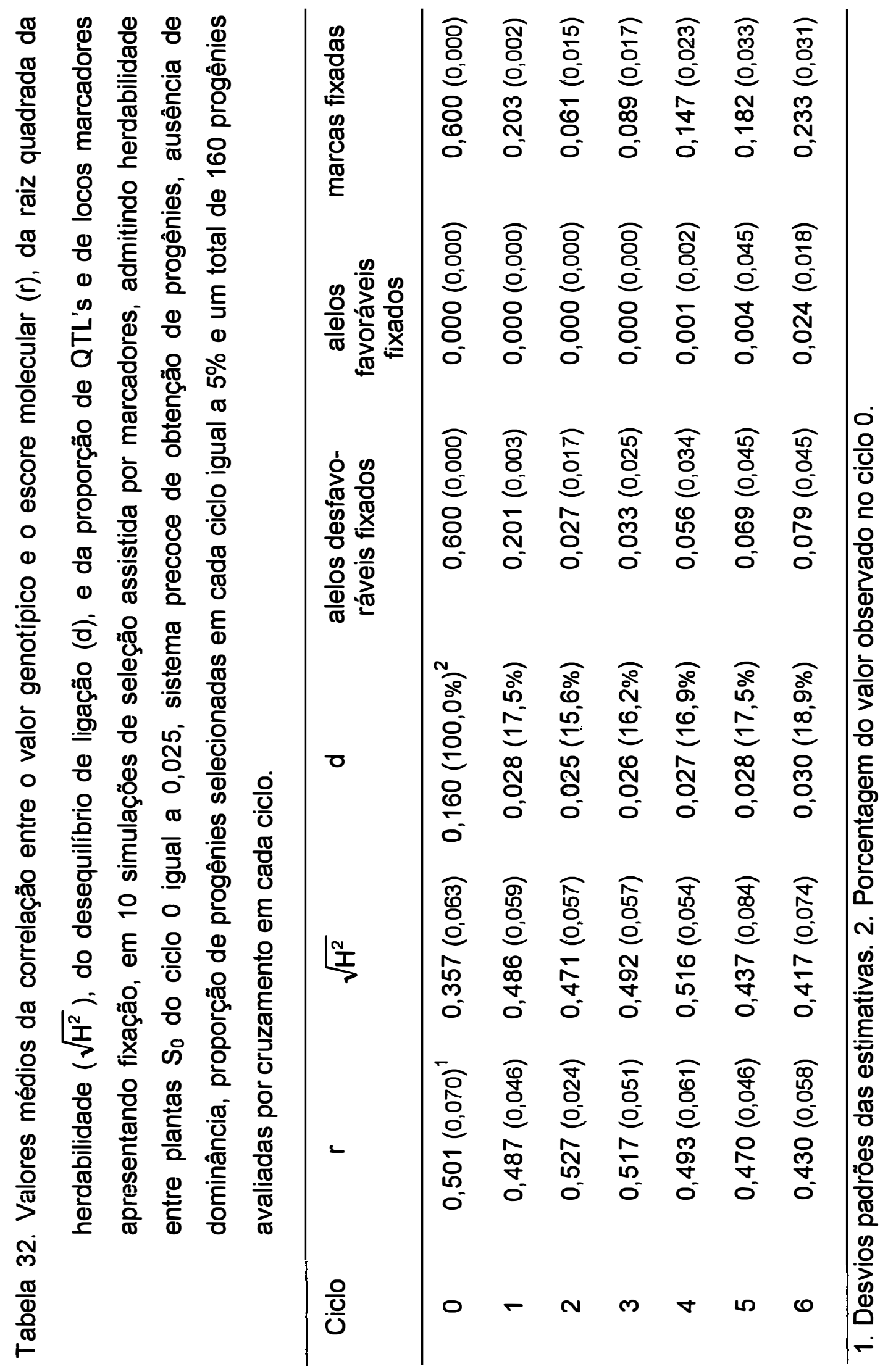




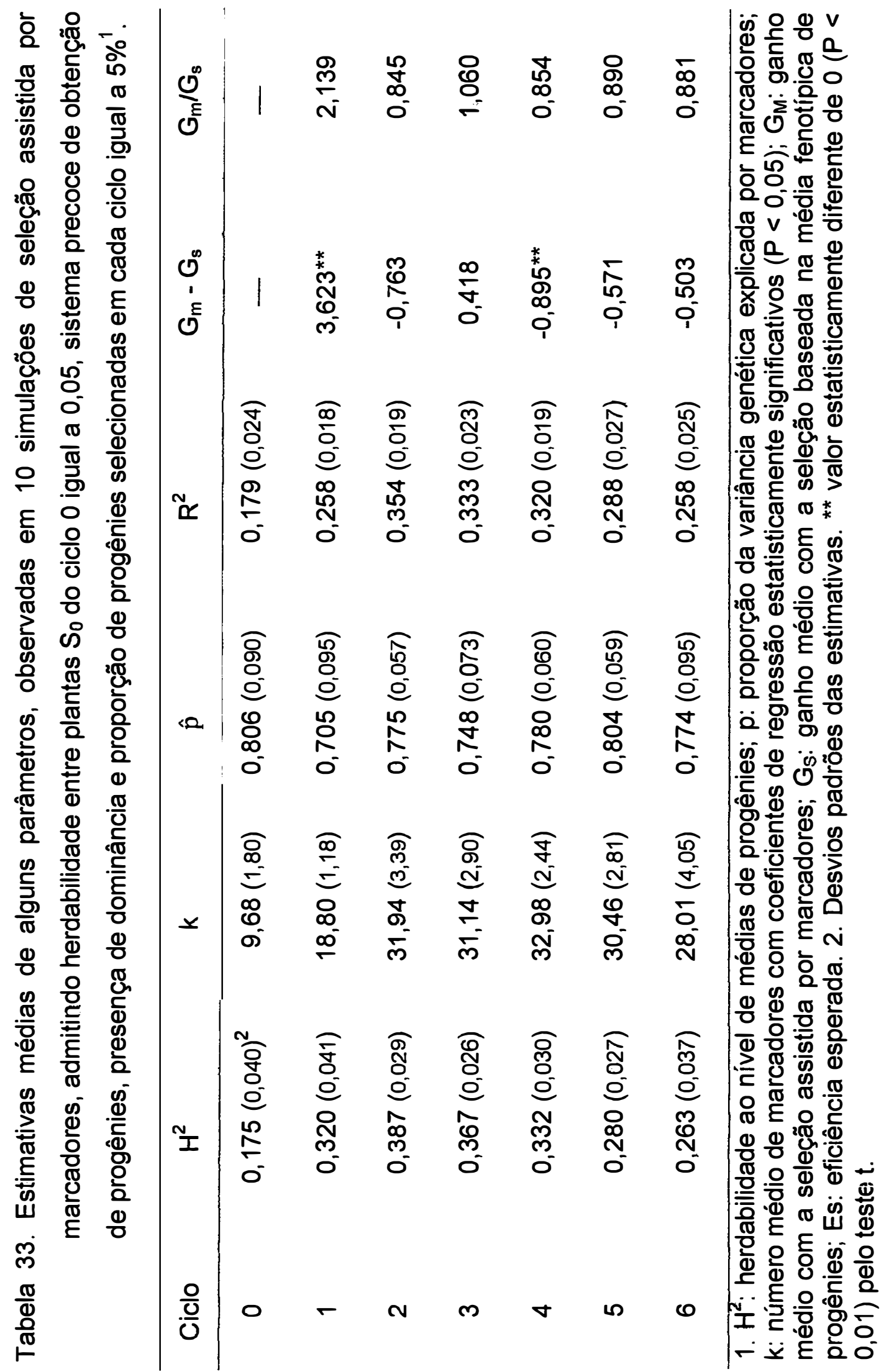




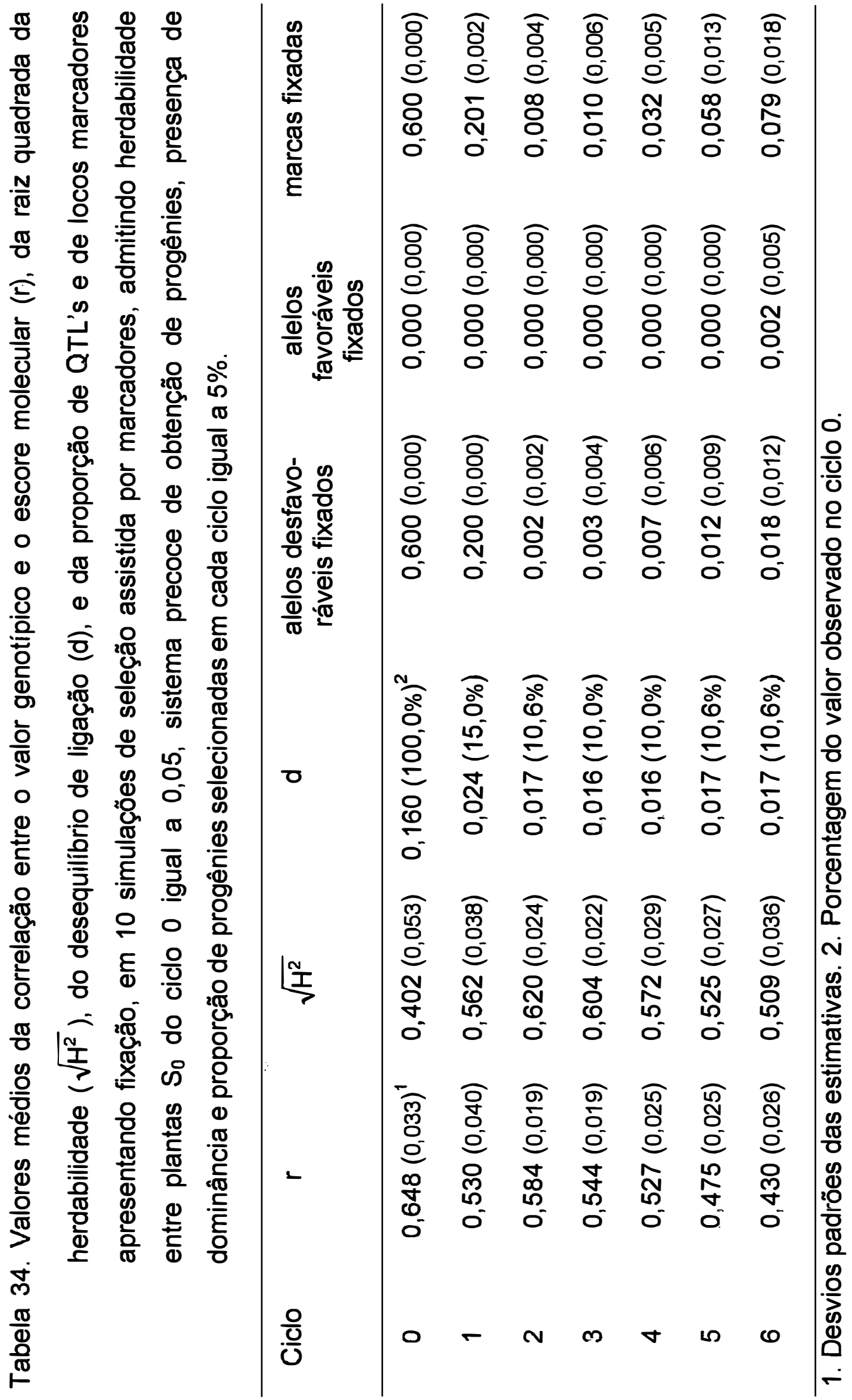




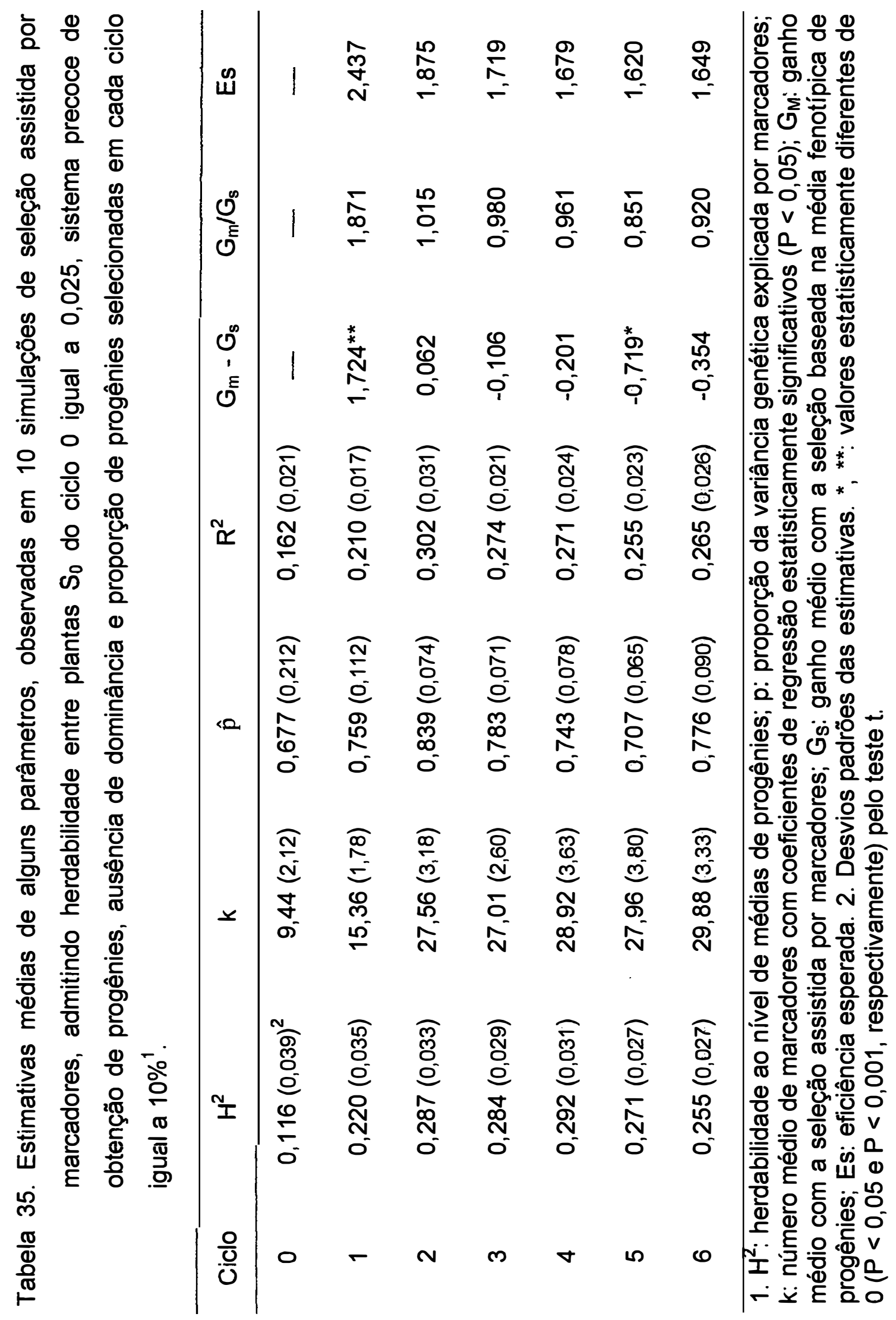




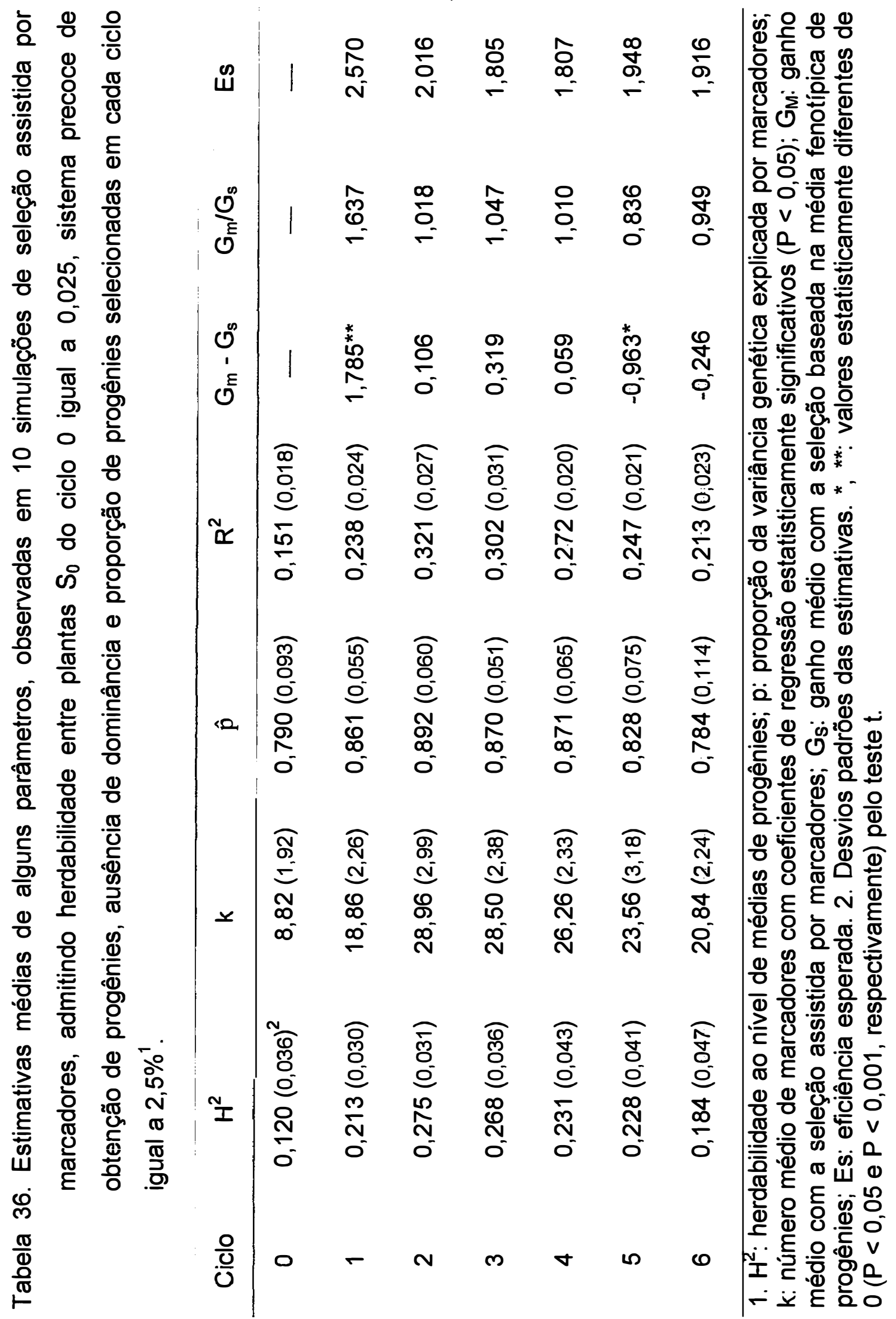




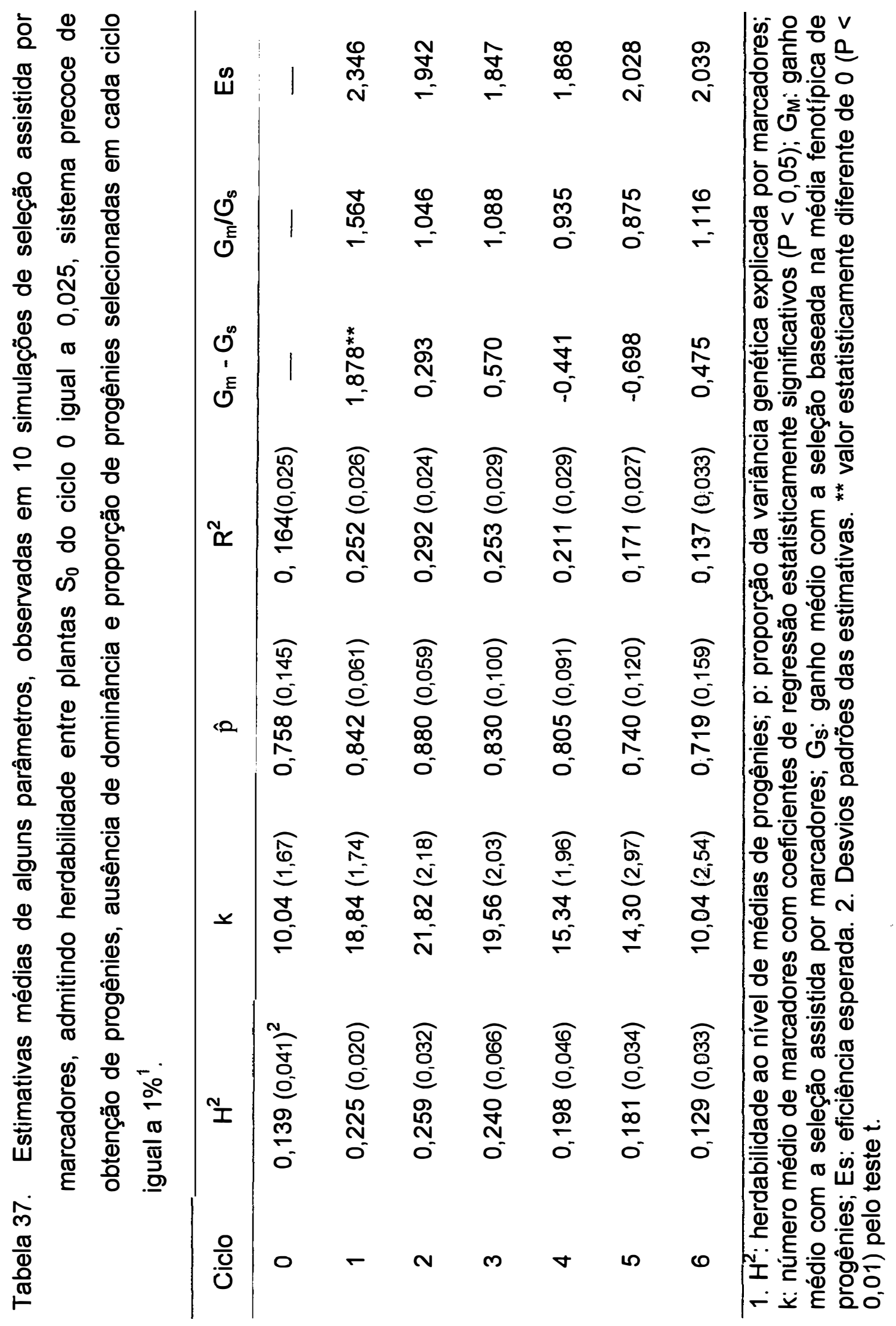




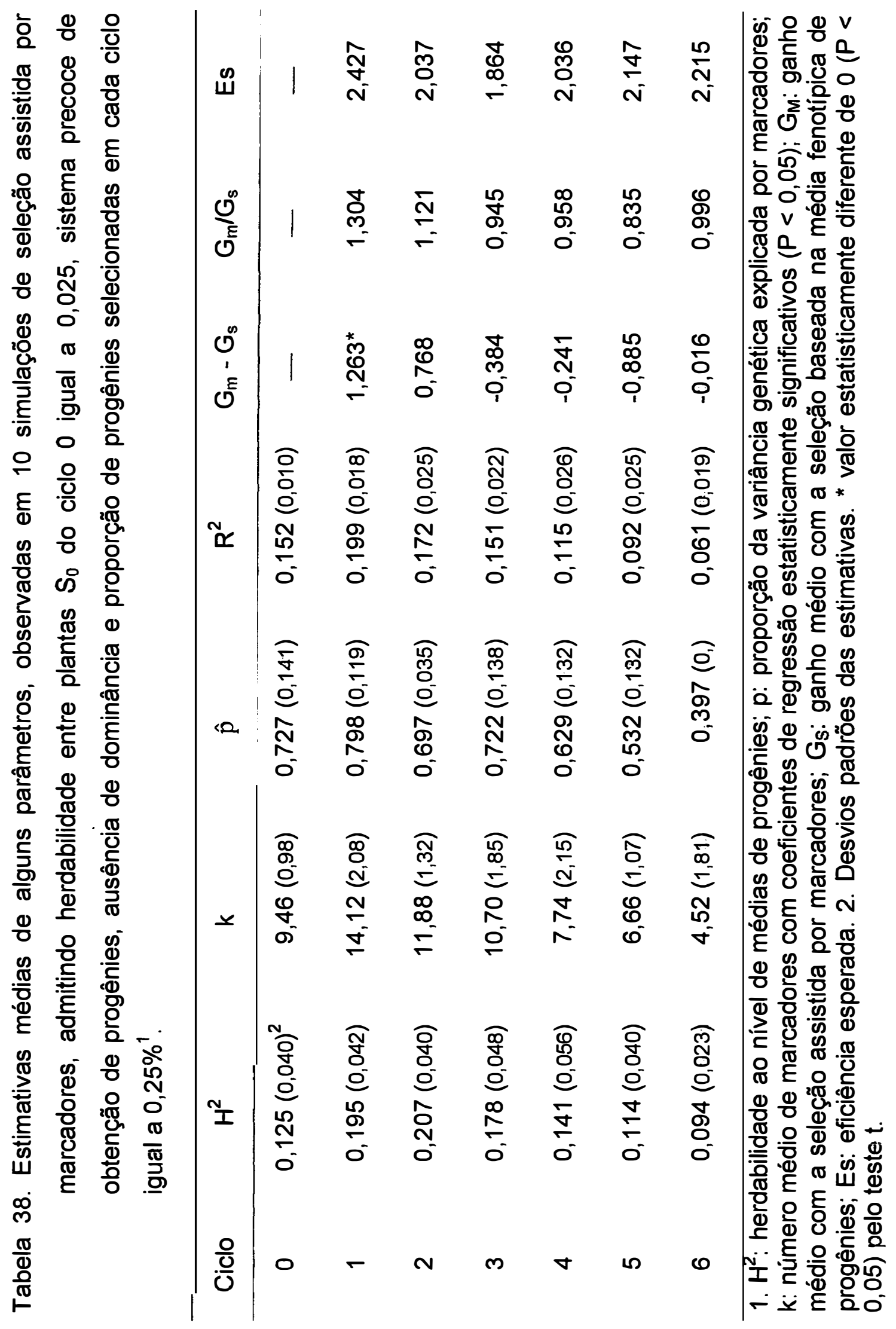




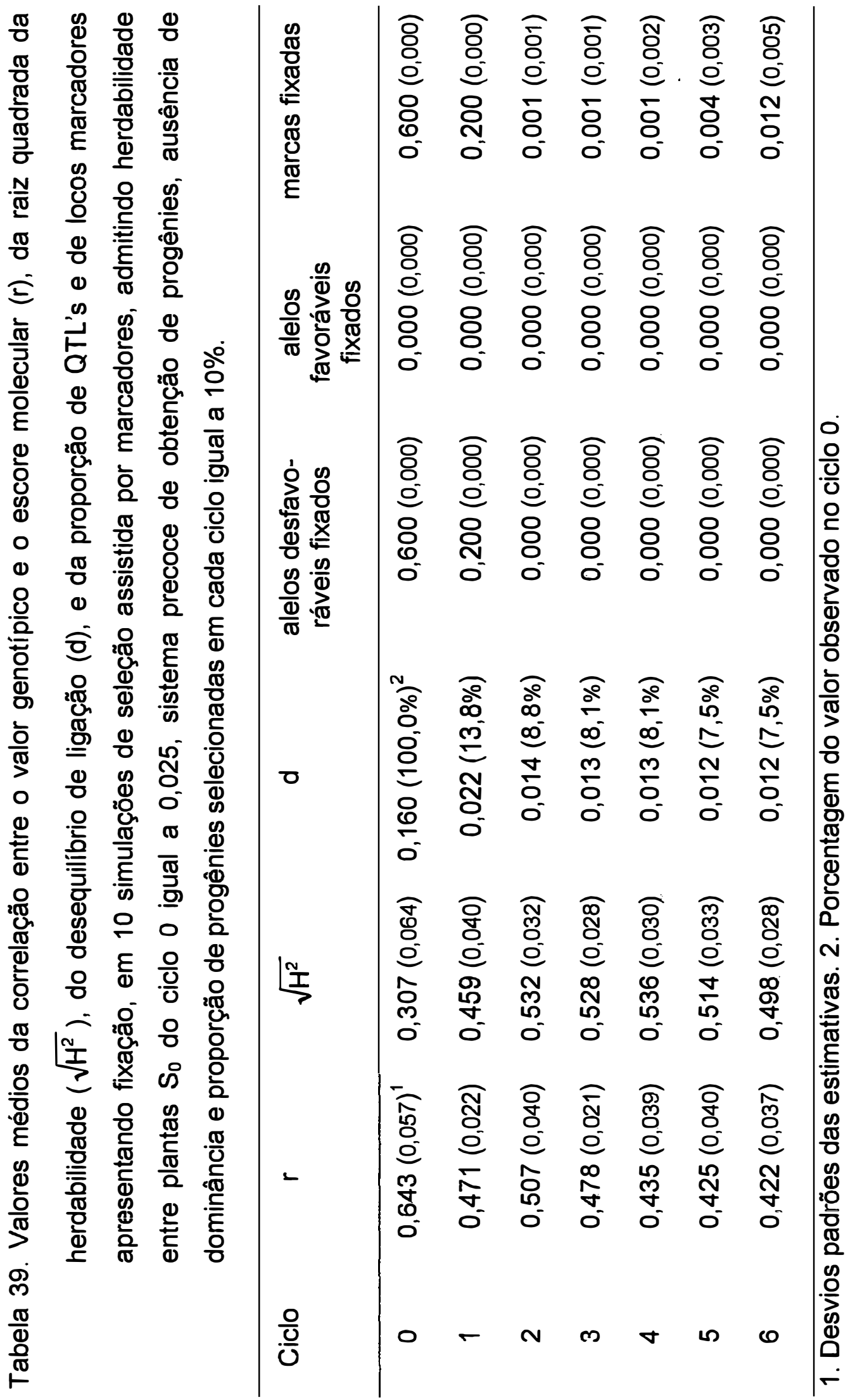




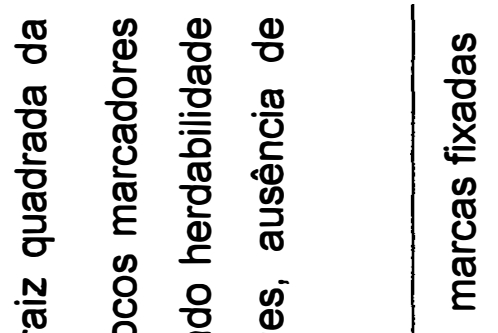

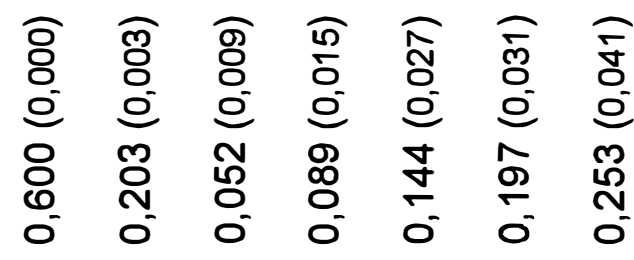

징

ऽ 1 व

克

娄

( )

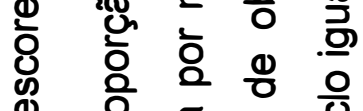

\& 응 중

( )

ช 0 औ

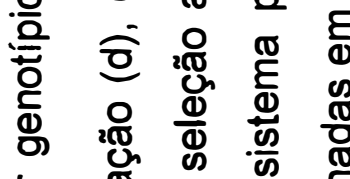

ᄒ

然

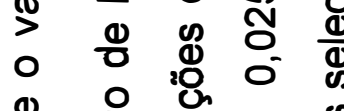

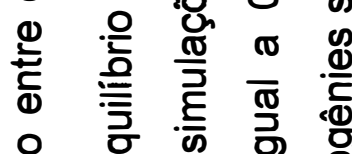

还

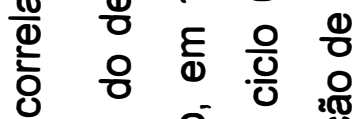

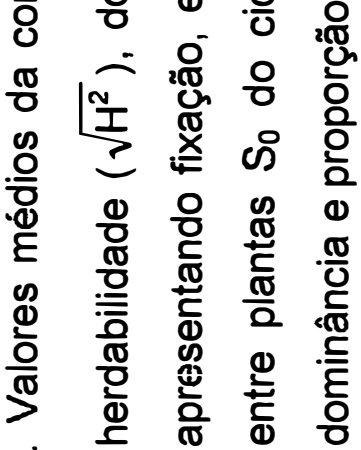

$\dot{q}$

它 :

क

ఫิ ठิ

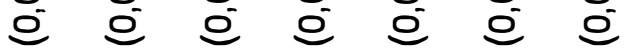

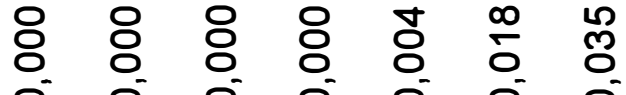

$\frac{\omega}{\omega} \frac{\pi}{0}$

赵

$\begin{array}{lllllll}0 & 0 & 0 & 0^{-} & 0^{-} & 0^{-} & 0^{-}\end{array}$

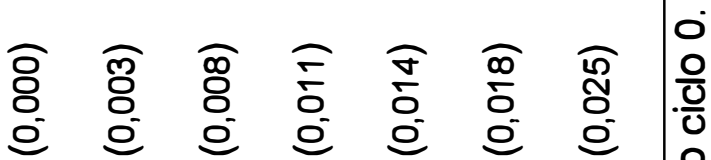

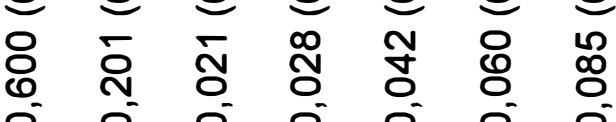

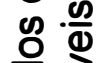

$\frac{\overline{0}}{\mathbb{\sigma}} \cdot \frac{\mathbb{d}}{\mathrm{d}}$

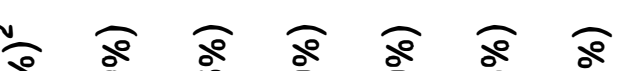

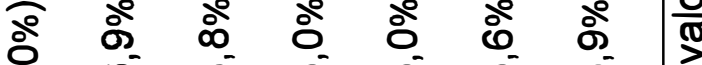

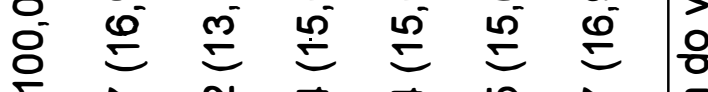

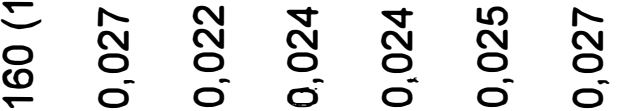

$\sigma^{-}$

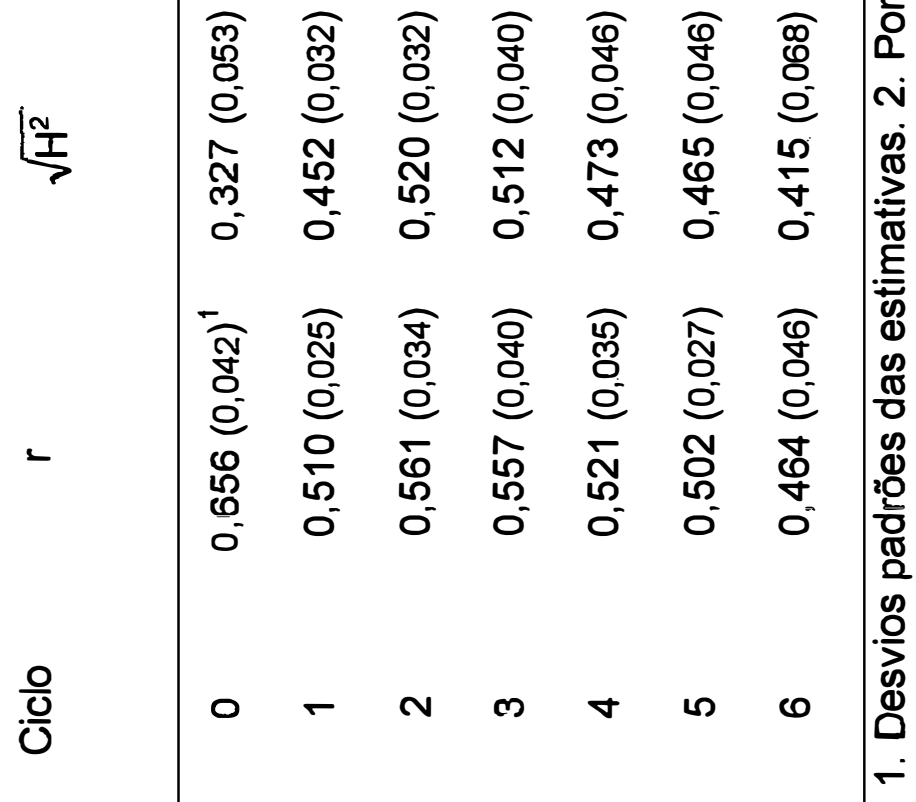

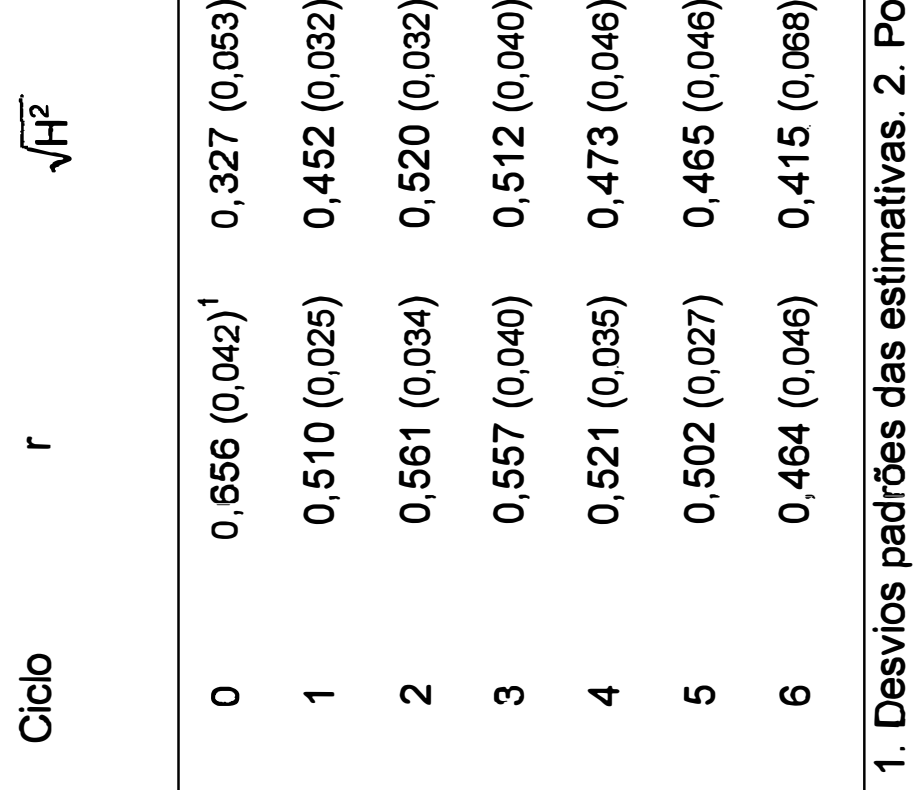

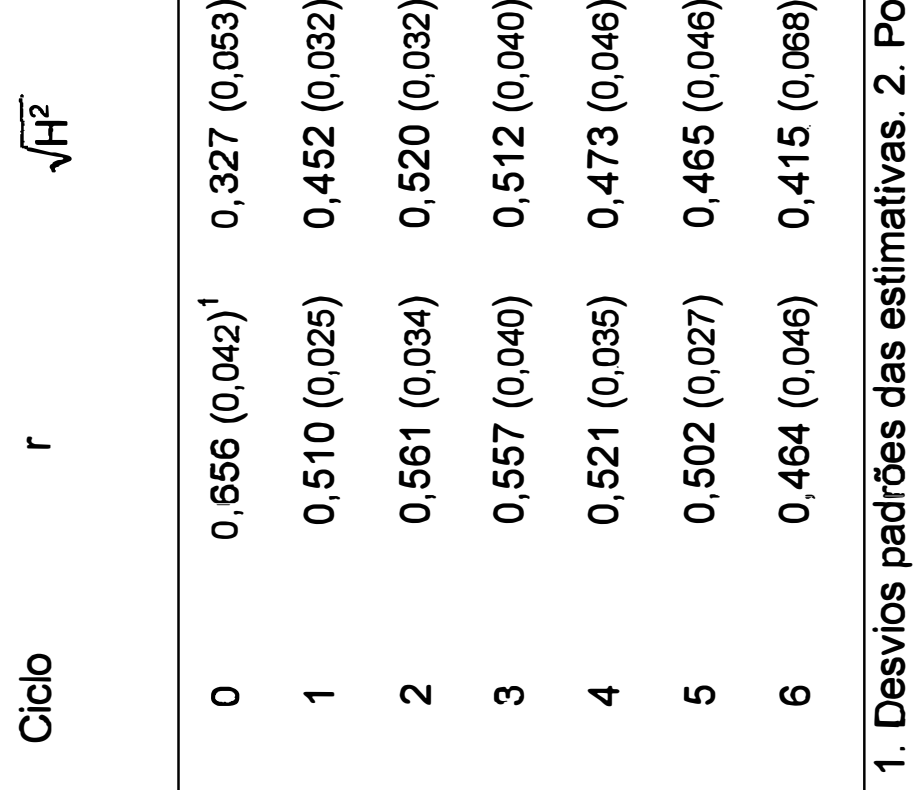

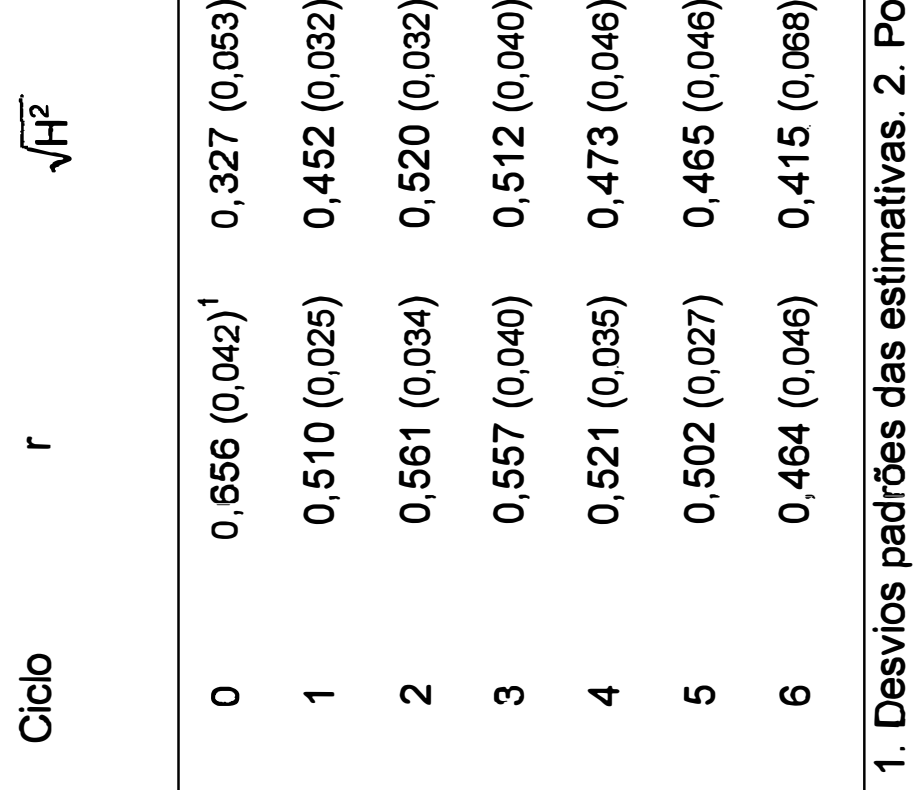

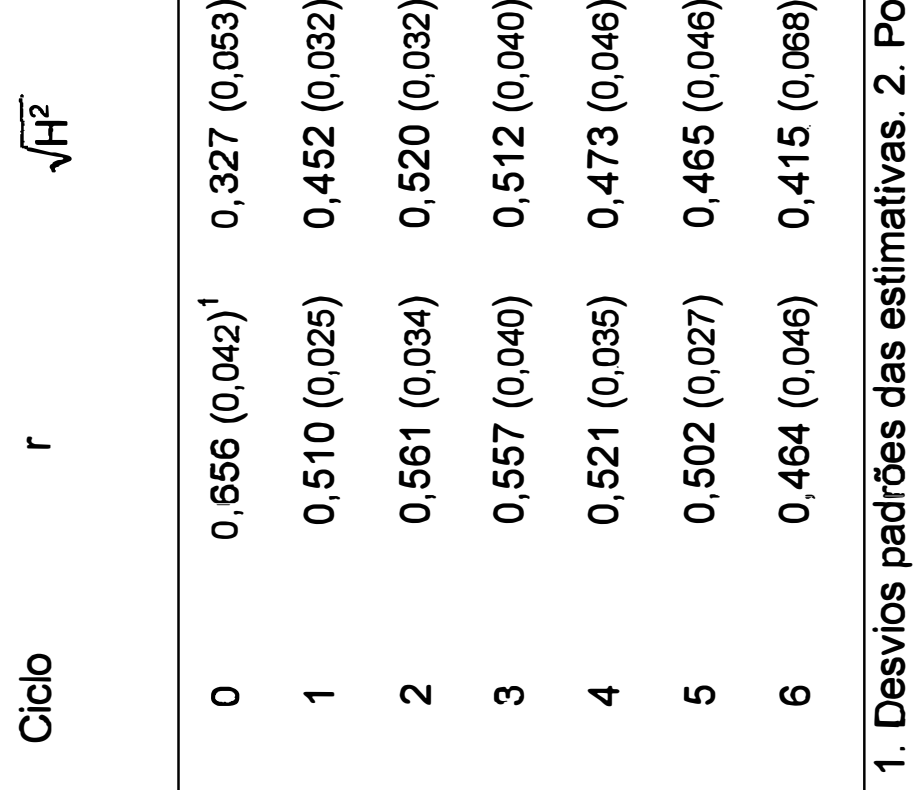

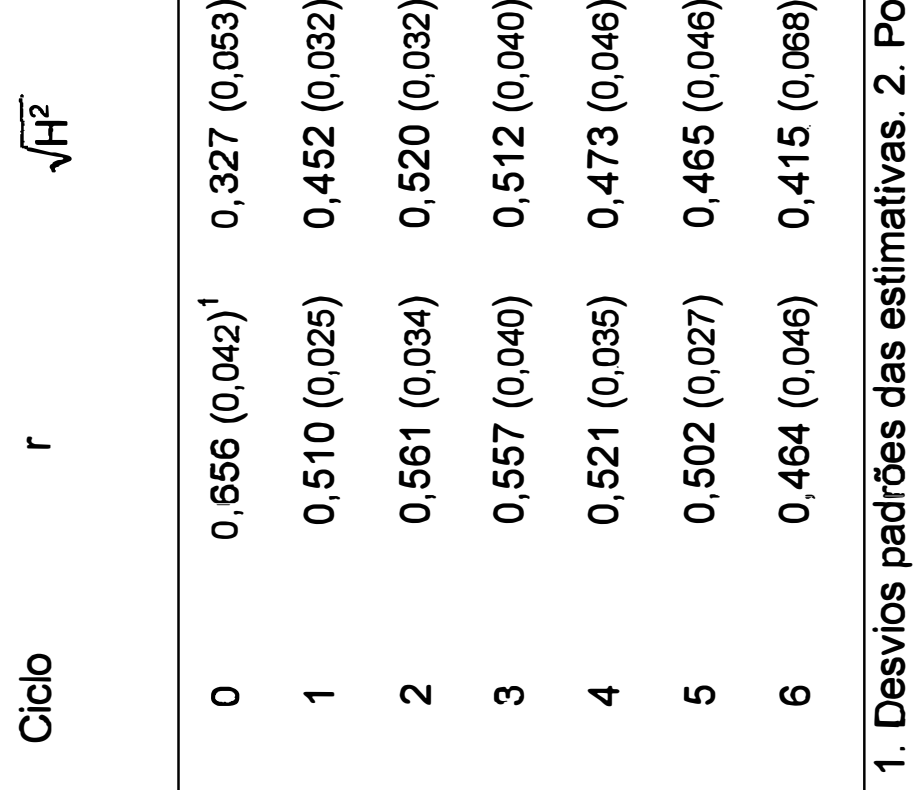

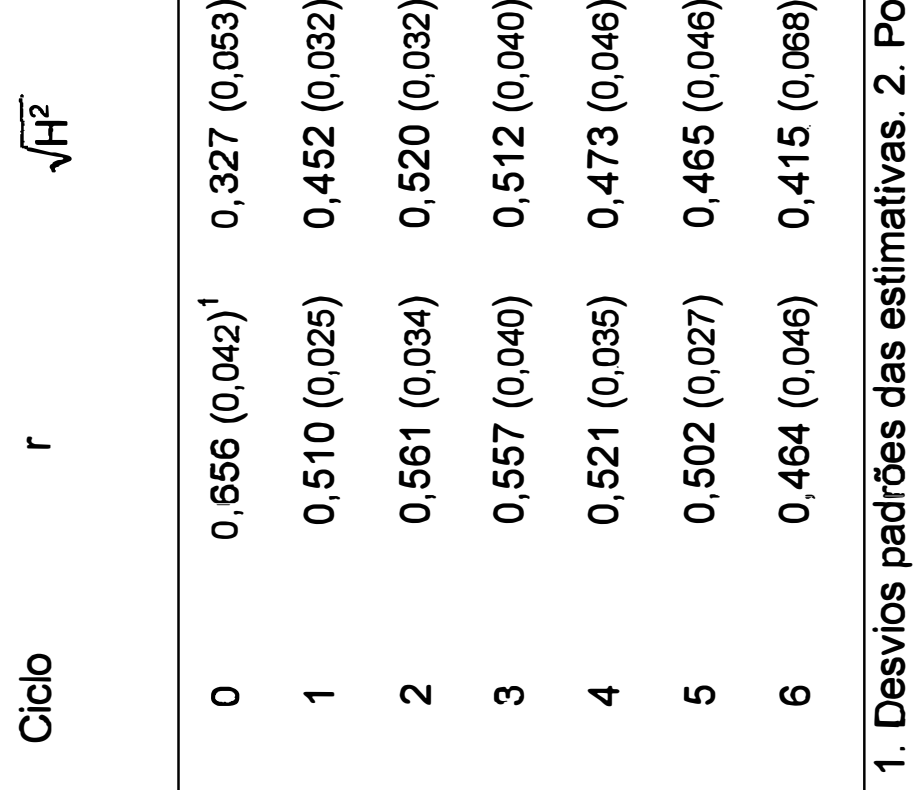

$\frac{\pi}{0}$ 


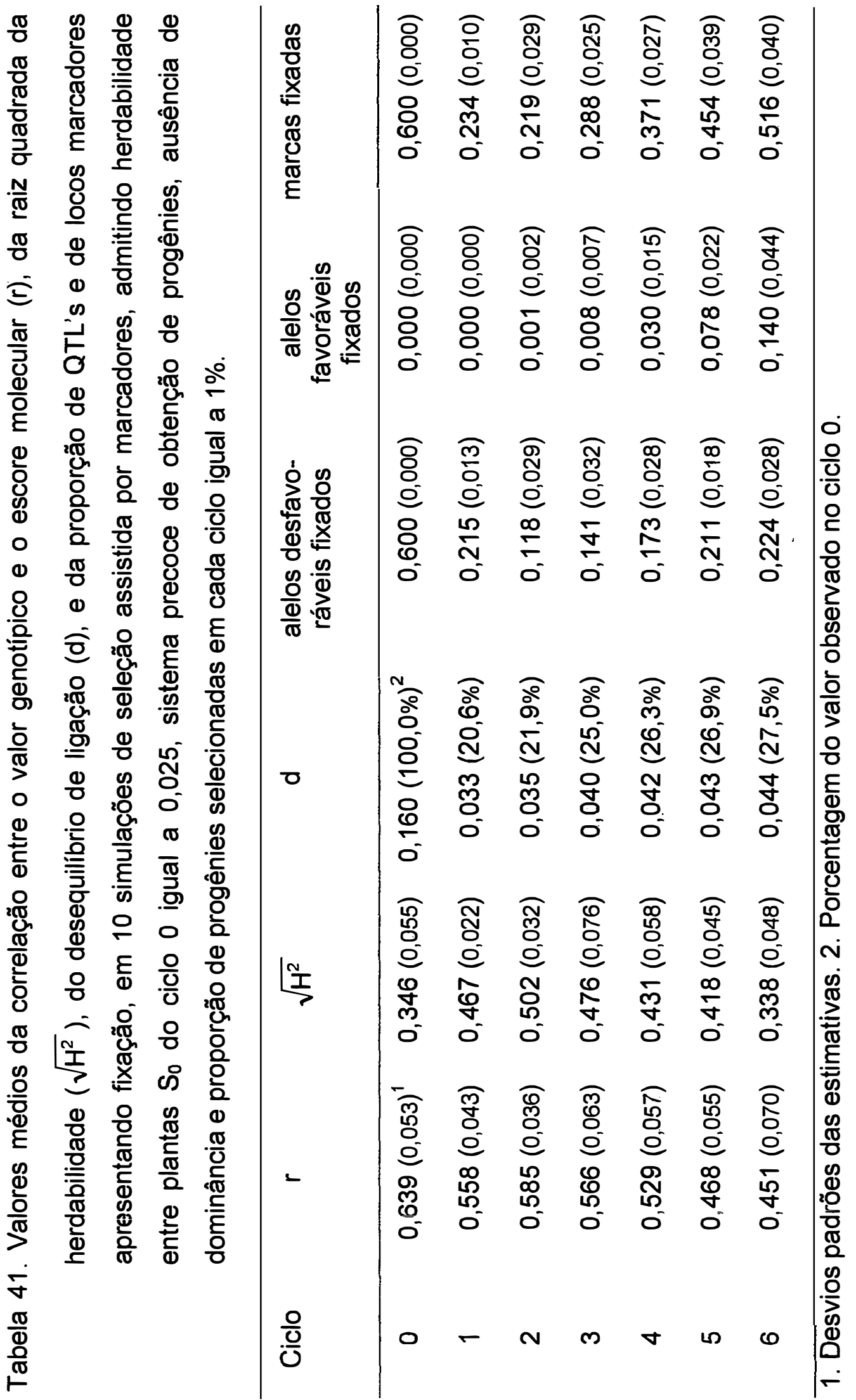




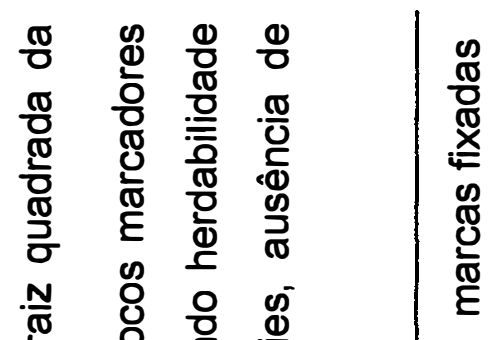

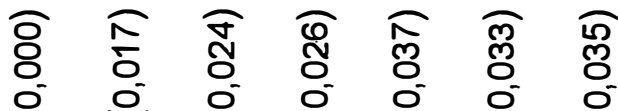

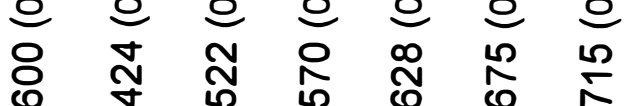

$\begin{array}{lllllll}0 & 0 & 0 & 0 & 0 & 0 & 0 \\ 0 & 0 & 0 & 0\end{array}$

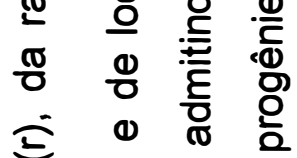

市 节

券

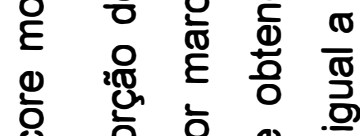

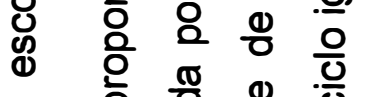

- 흠 인

- $\frac{\pi}{0}$ :

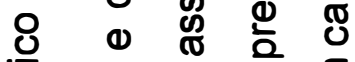

흠

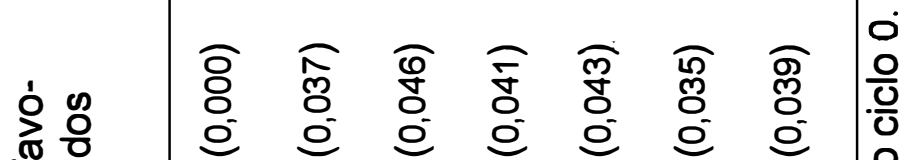

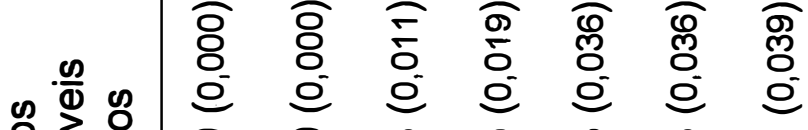

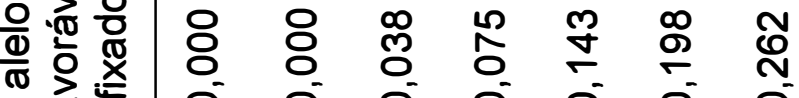

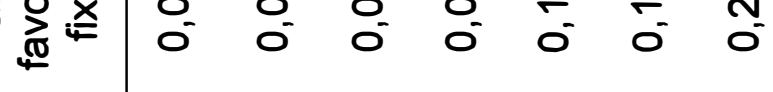

递

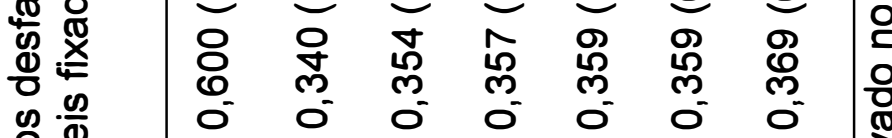

$\frac{\frac{0}{0}}{\frac{0}{\omega}} \cdot \frac{\pi}{\pi}$

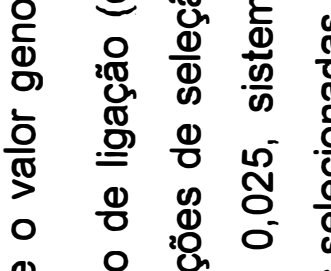

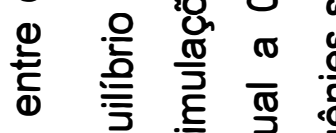

흥

总

힝

(1) 200

$\stackrel{n}{\frac{1}{3}}$

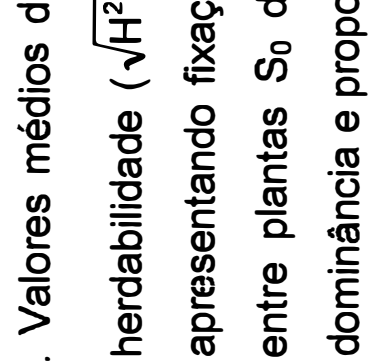
ขั

$\frac{\frac{\pi}{0}}{\frac{0}{\sigma}}$

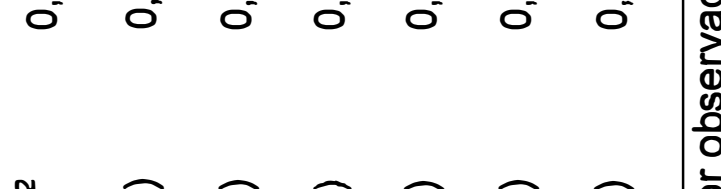

\%े वे वे

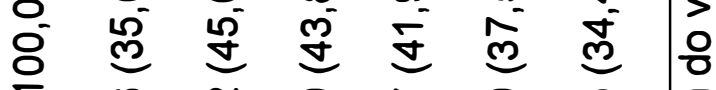

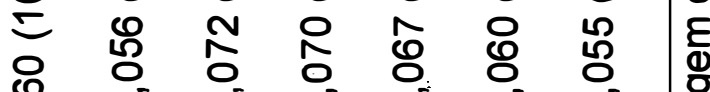

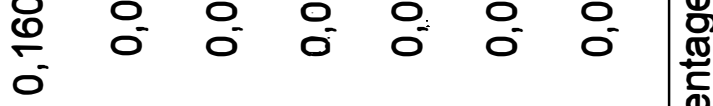

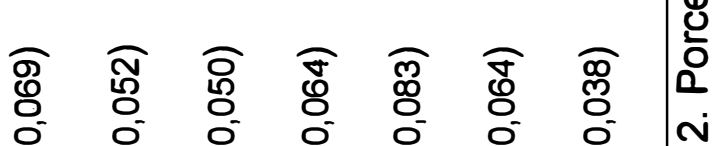

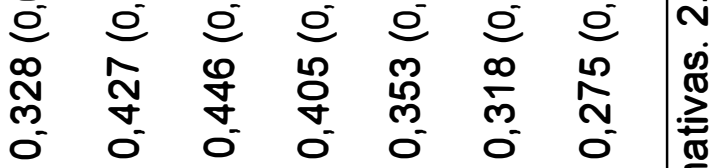

茯

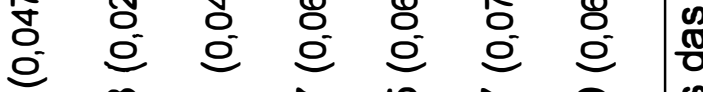

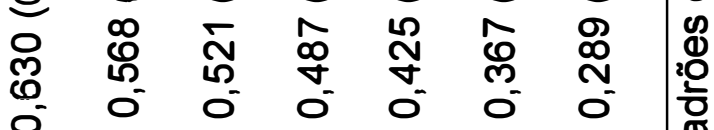

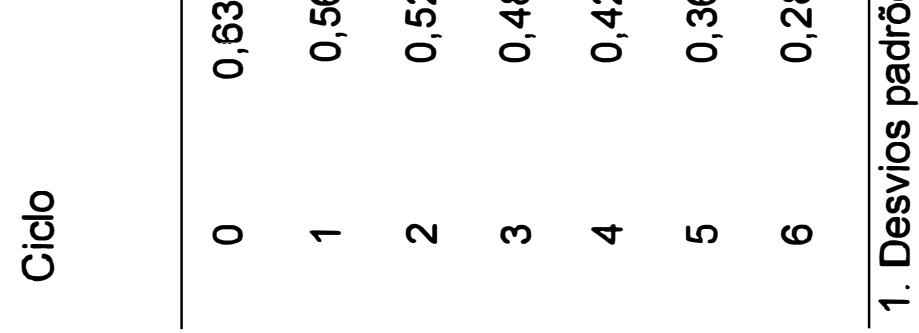




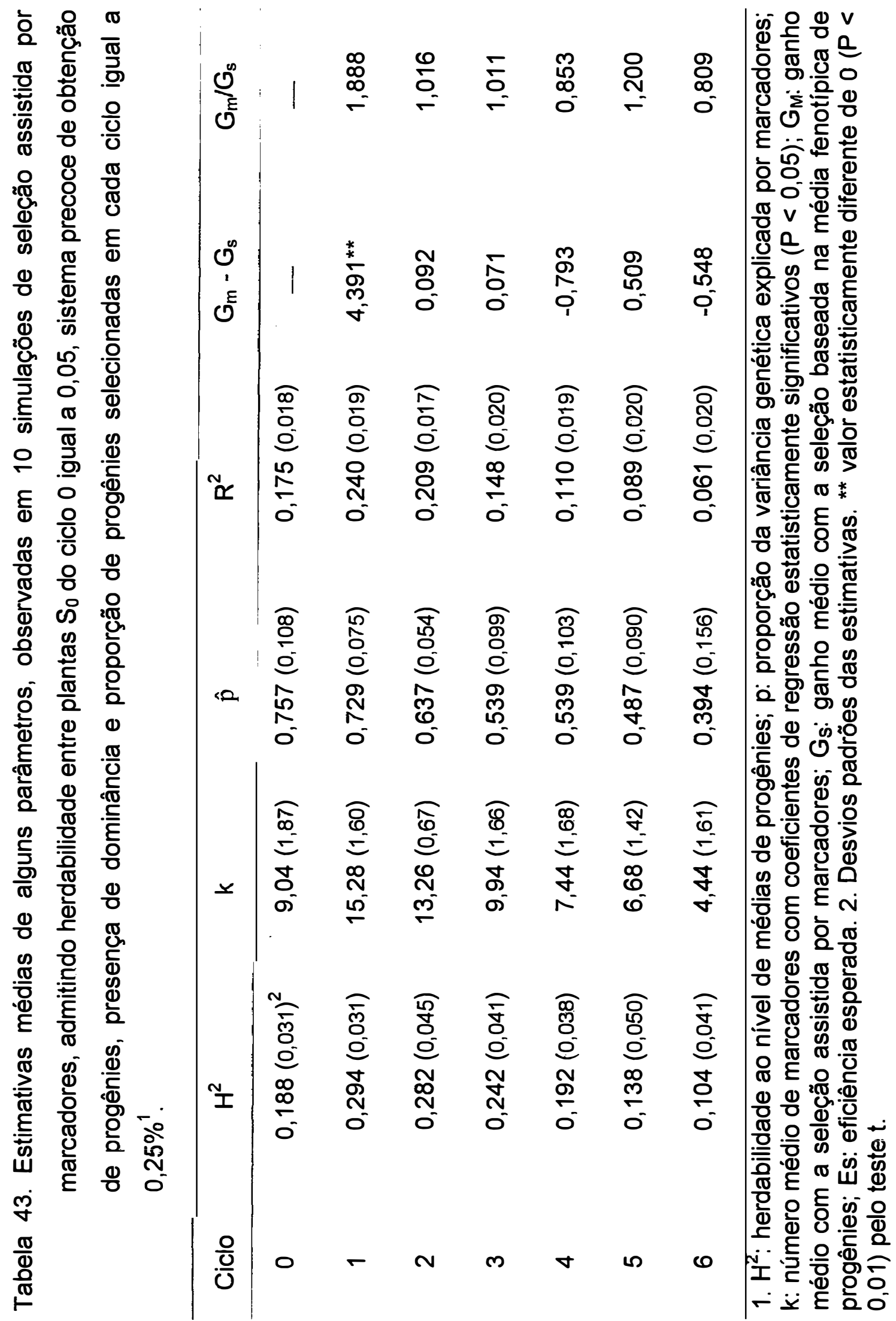




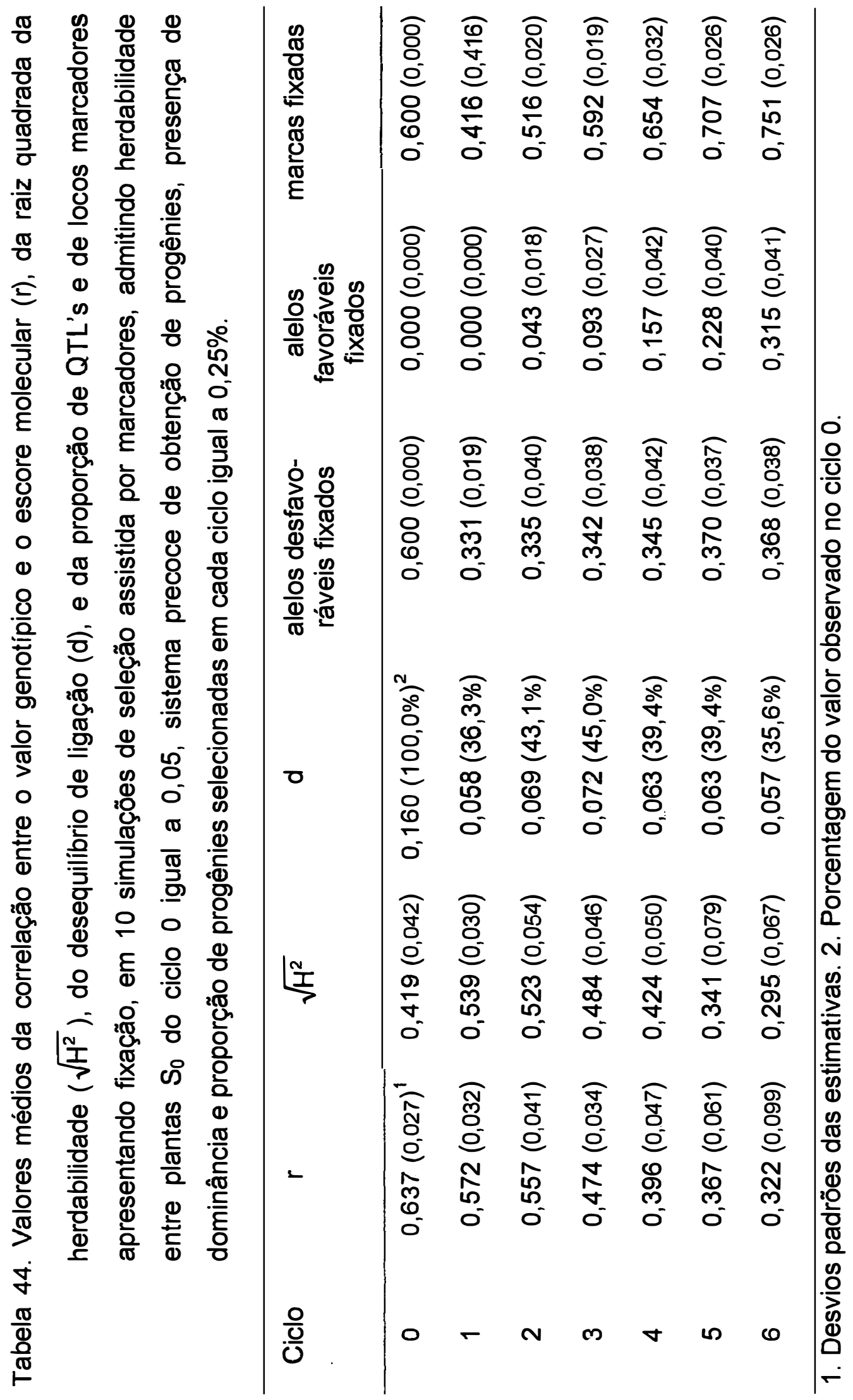




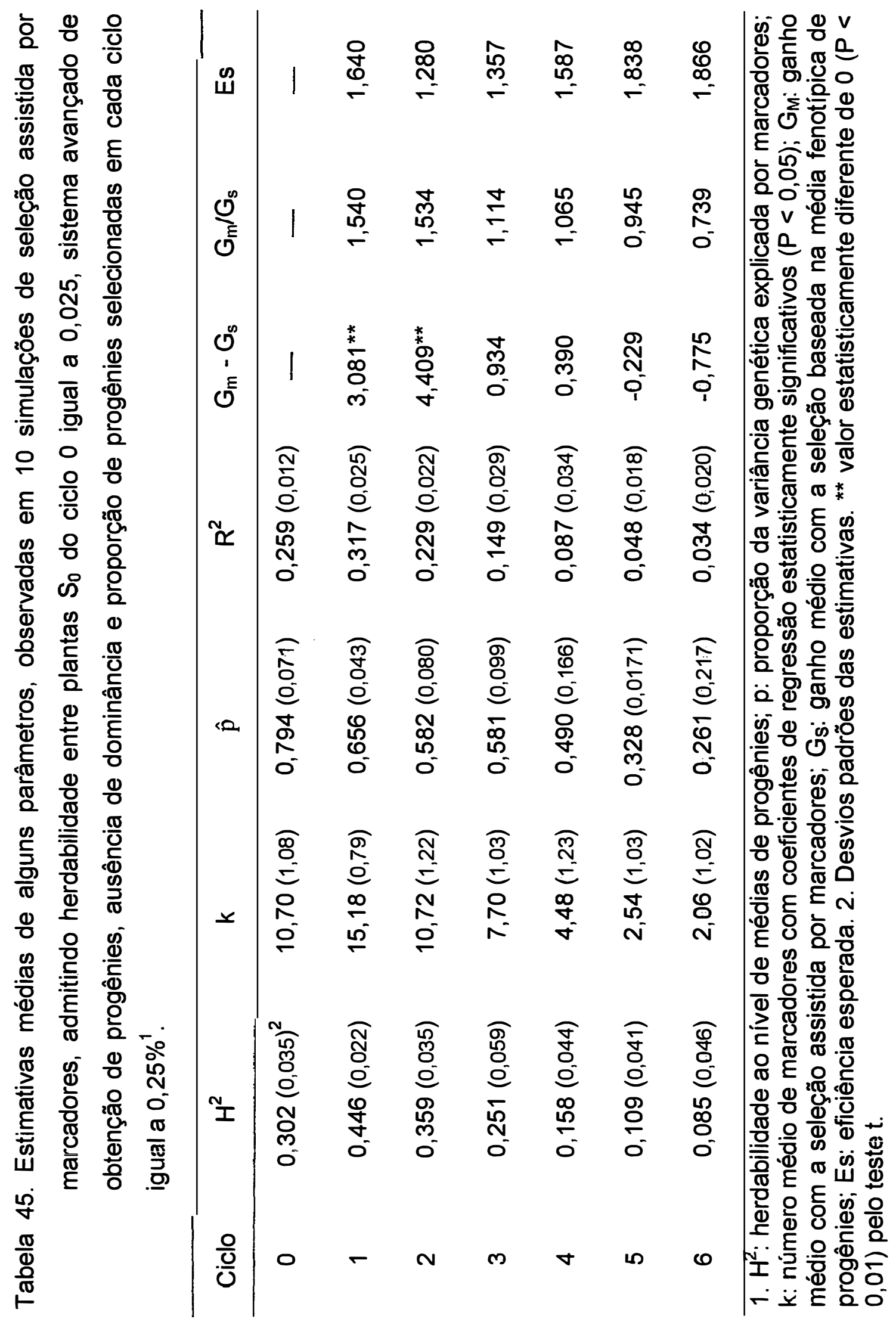




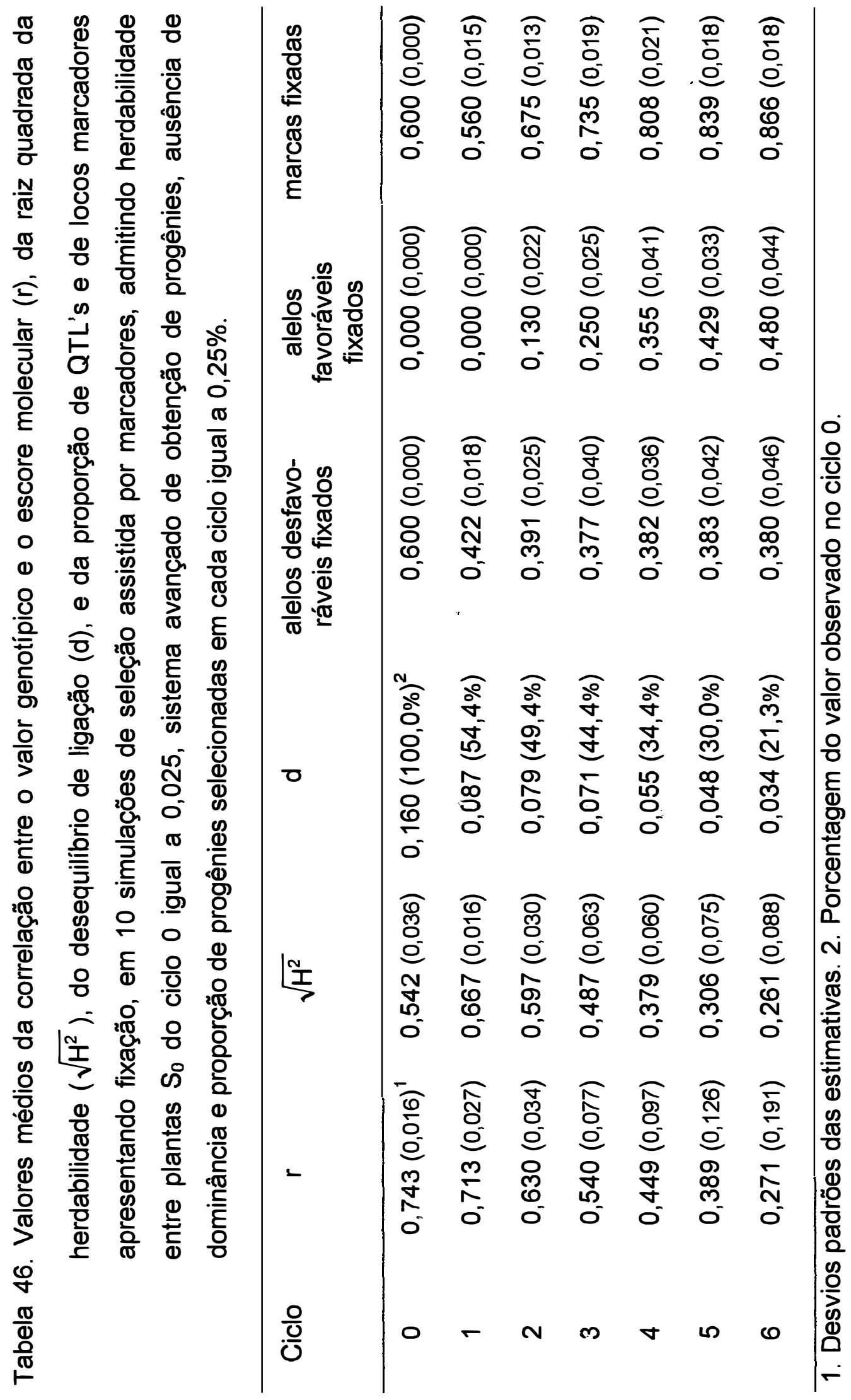




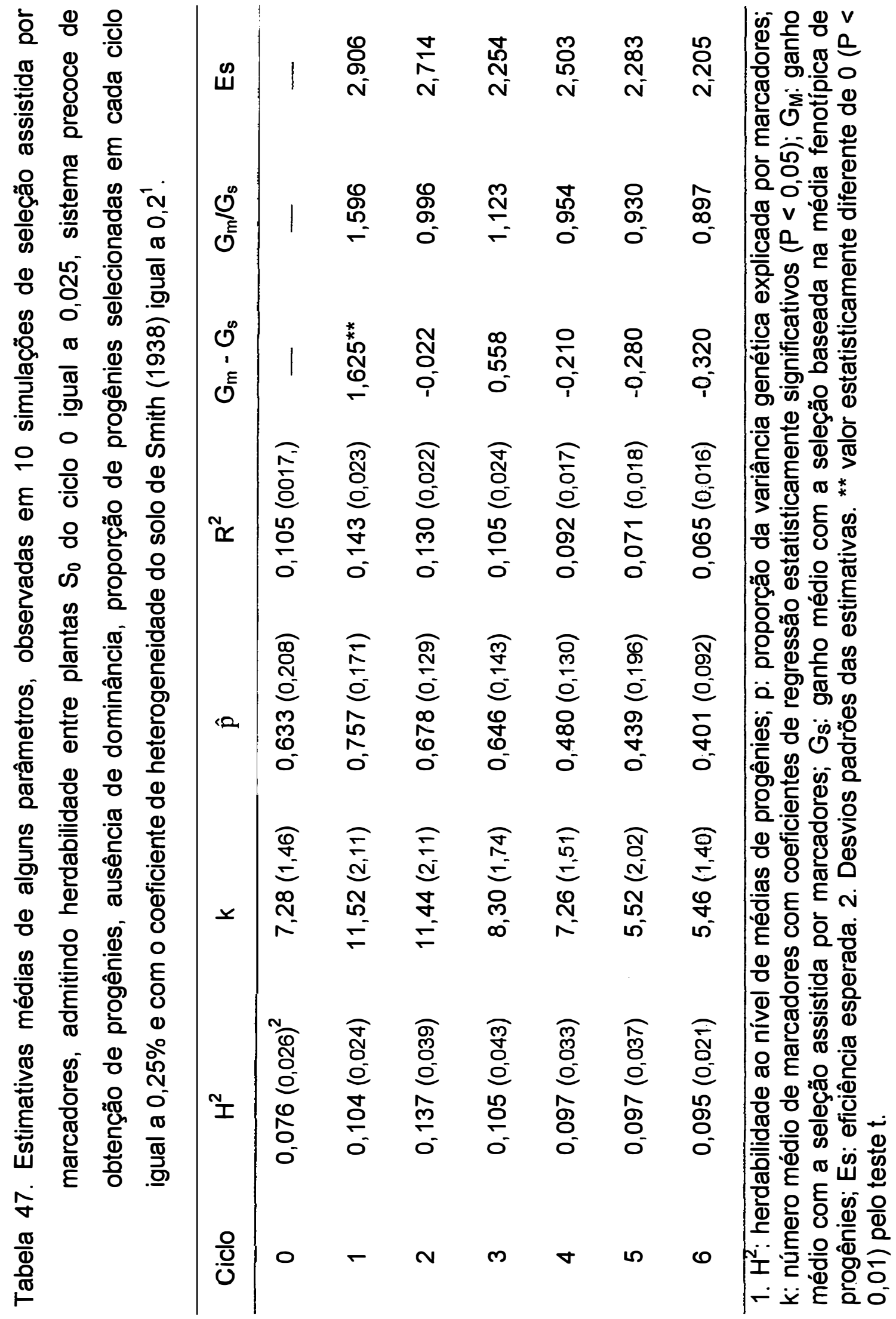




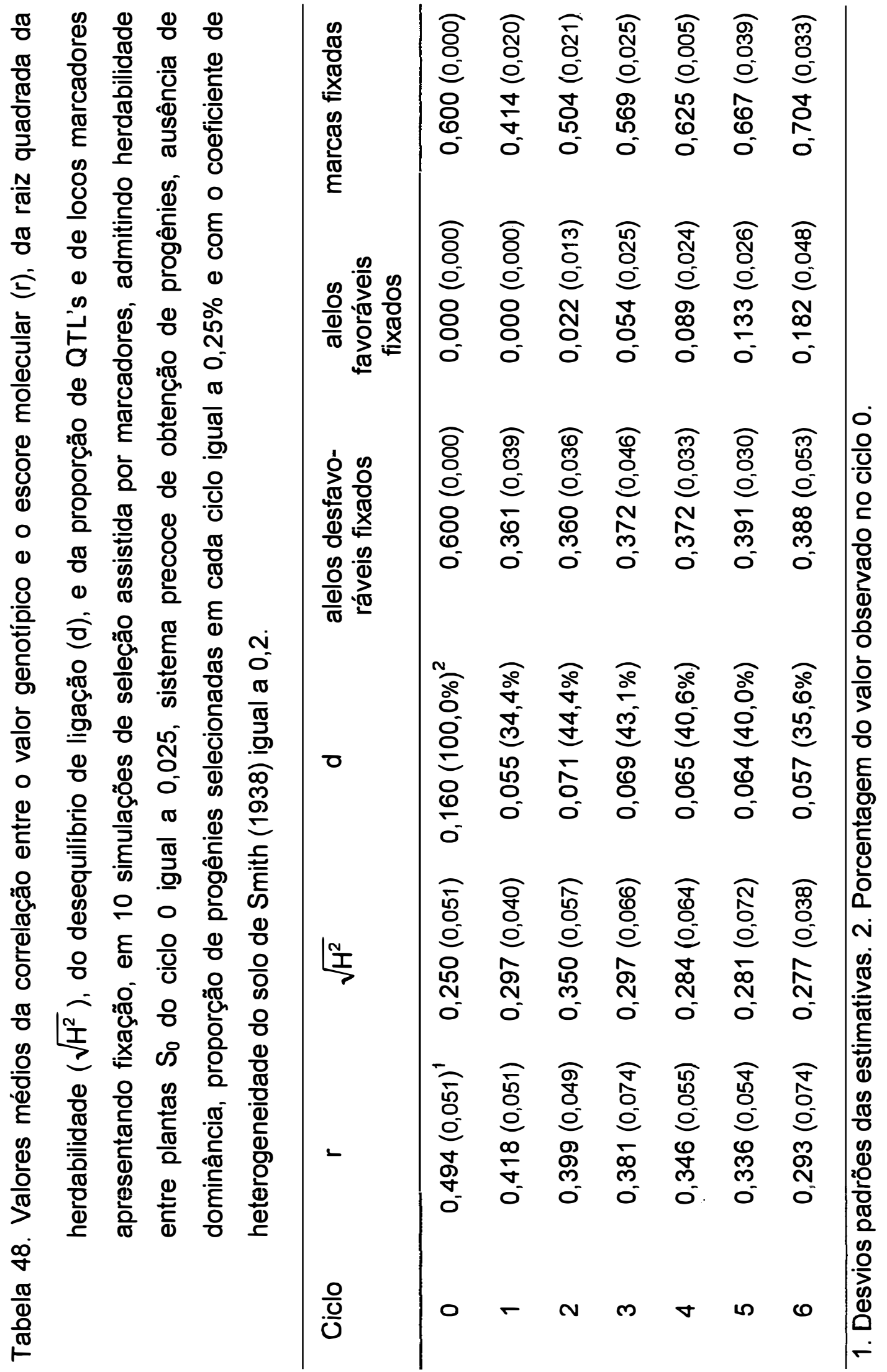




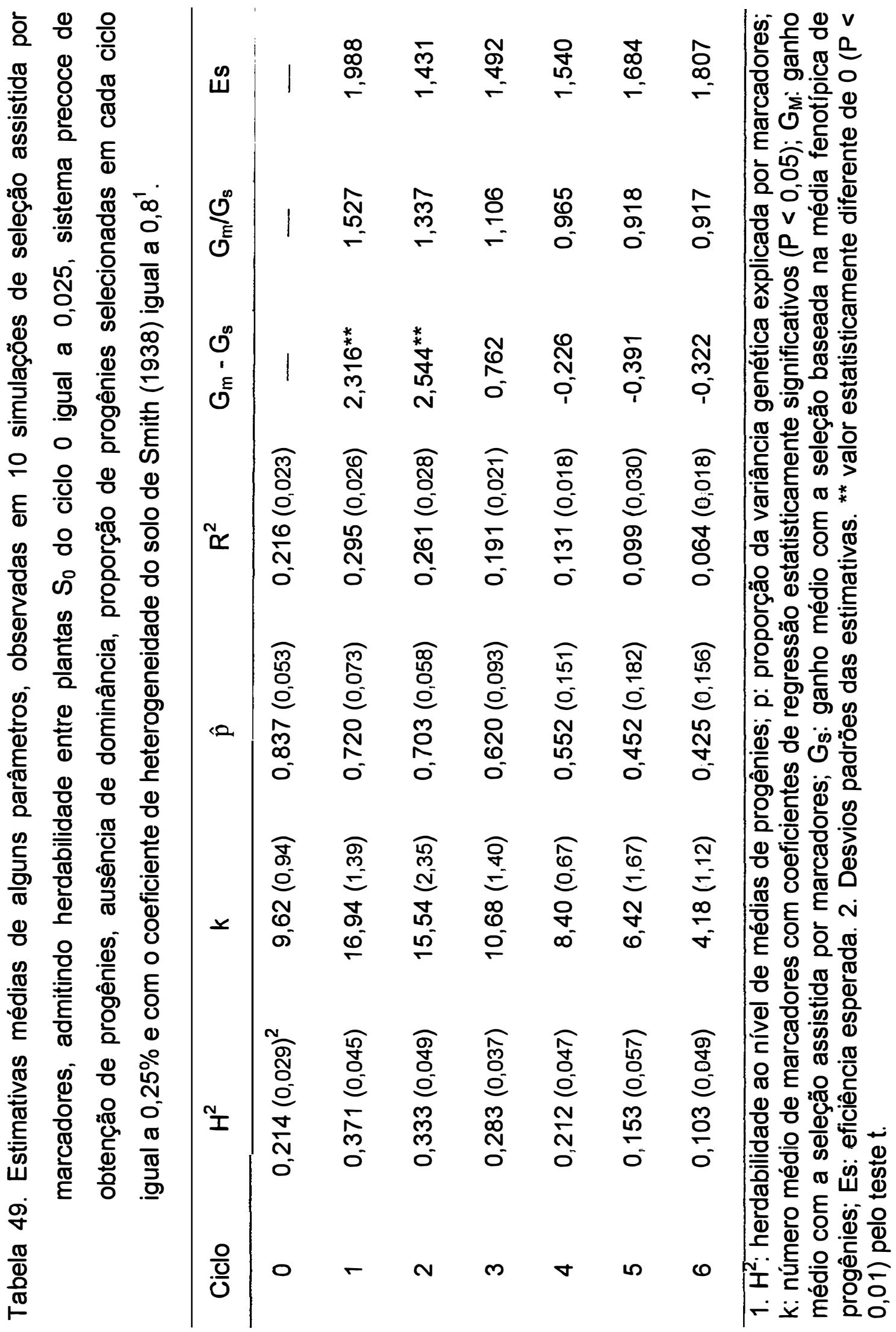




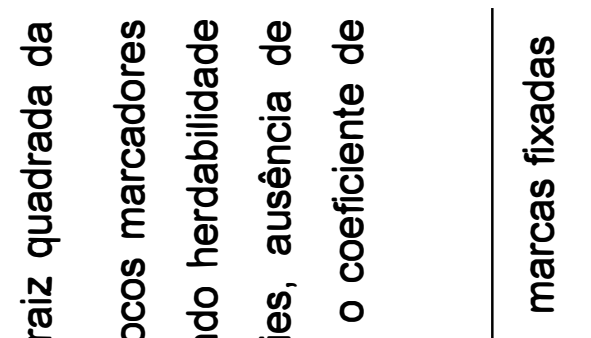

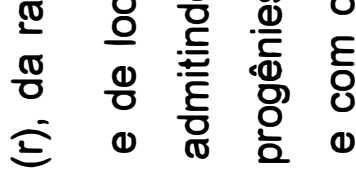

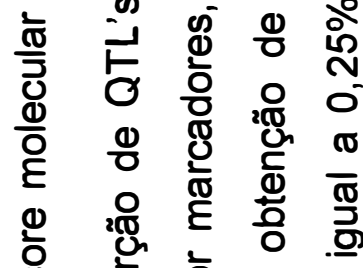

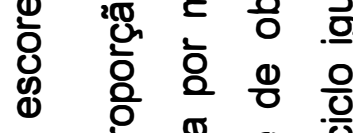

○

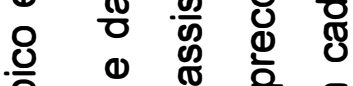

응

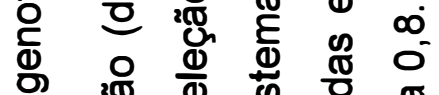

20

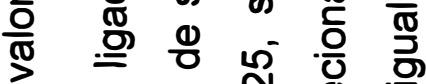

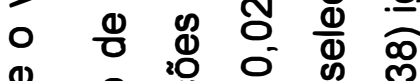

ญ 은

일

20.

땐

응 응 $\frac{E}{\Phi}$ 은 $\frac{\Phi}{0}$

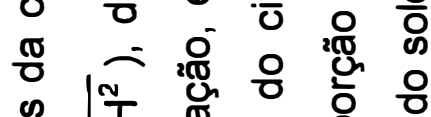

.

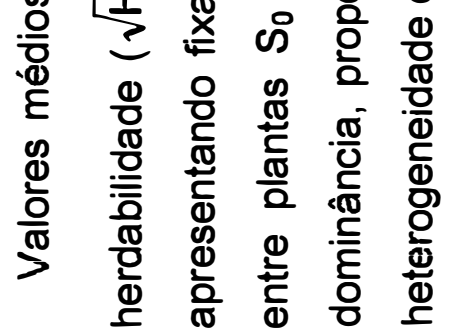

is

$\frac{\pi}{2}$

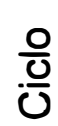

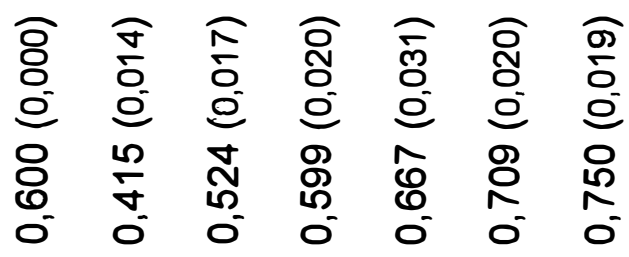

จ $\widehat{8}$ ণิ

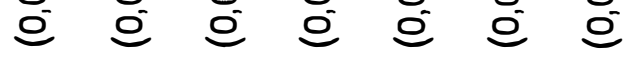

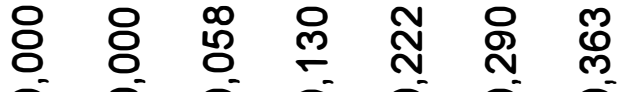

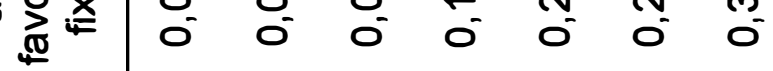

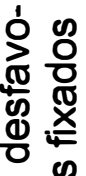

을 $\frac{\text { D }}{10}$

$\frac{\mathrm{d}}{\omega} \cdot \frac{\mathrm{\sigma}}{\mathrm{N}}$

๙ิ

\& ल ल

:

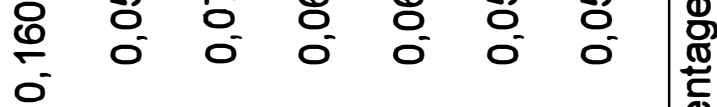

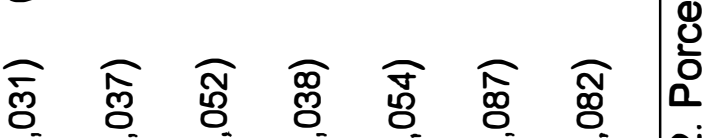

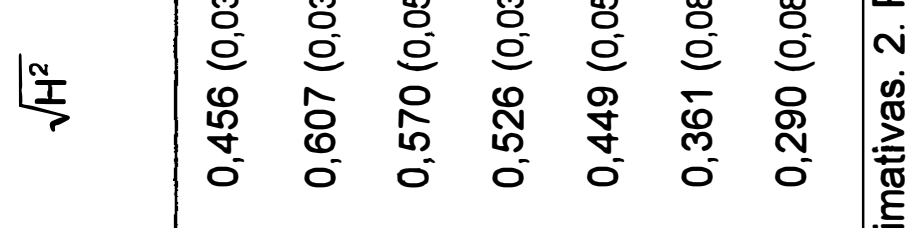

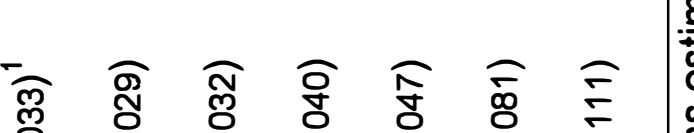

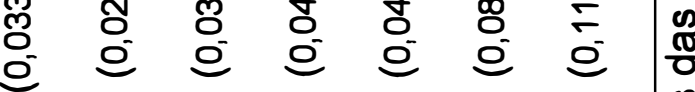

시시

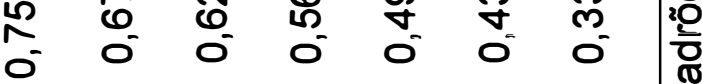

$0-N \infty \forall n$ 


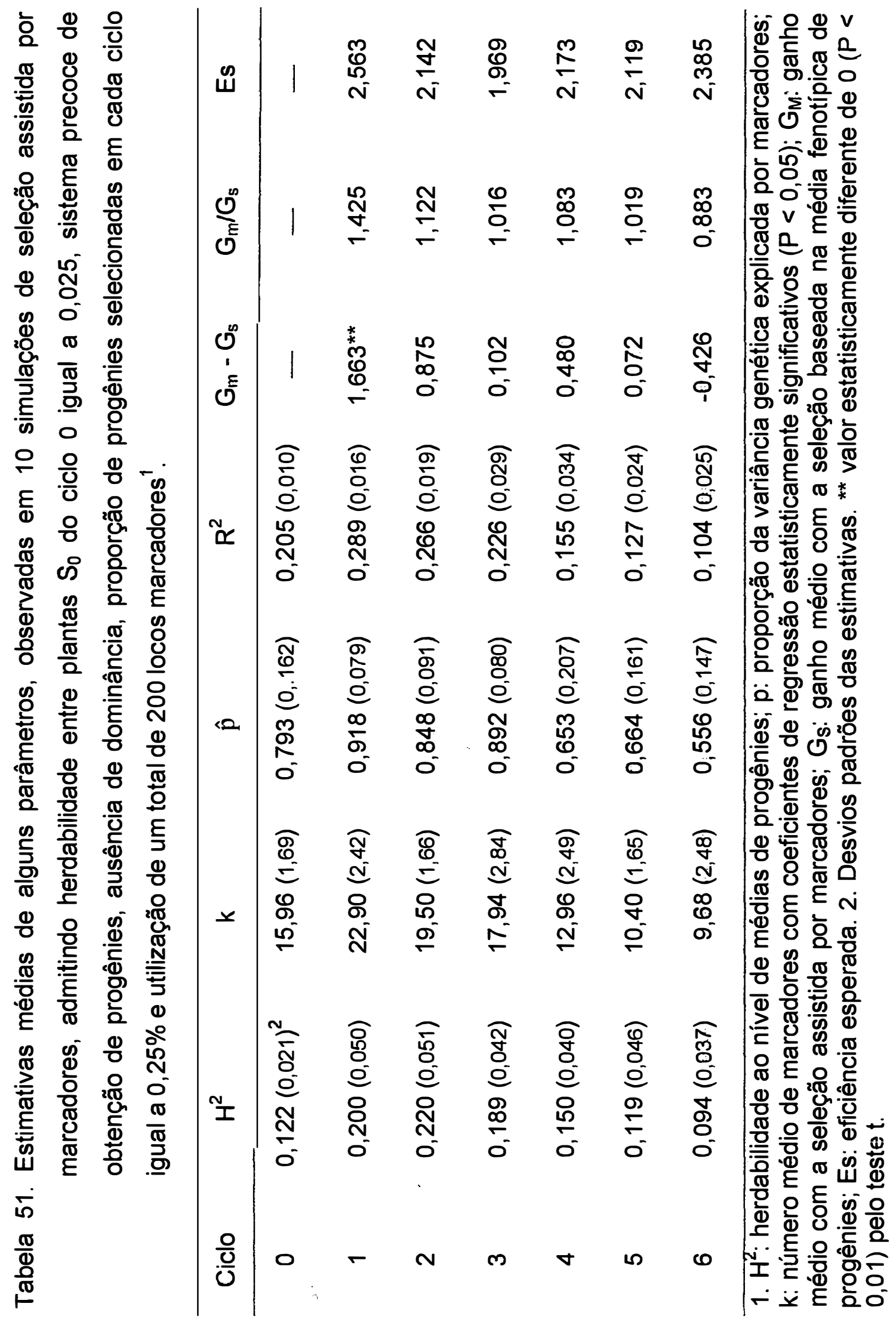




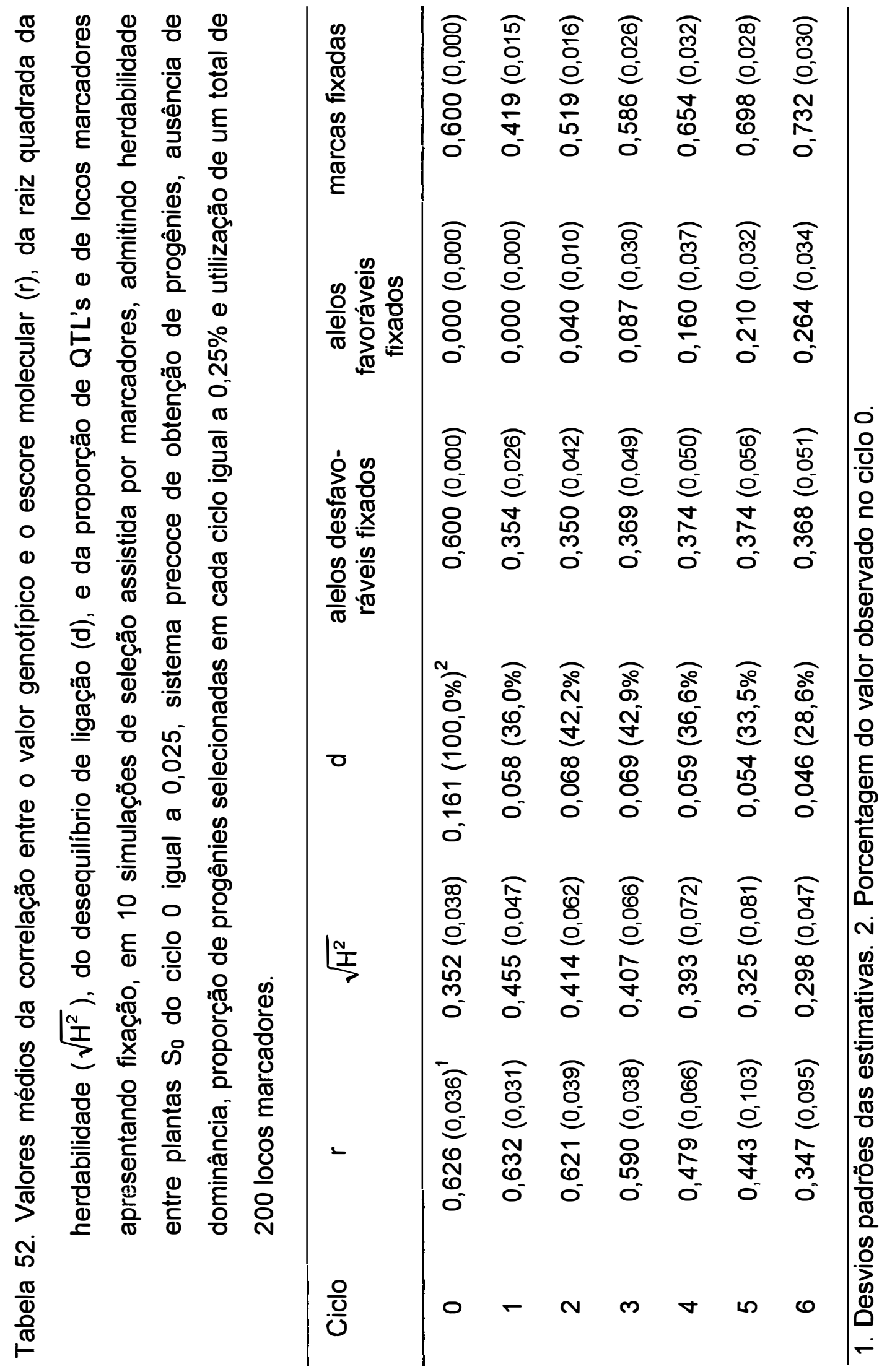




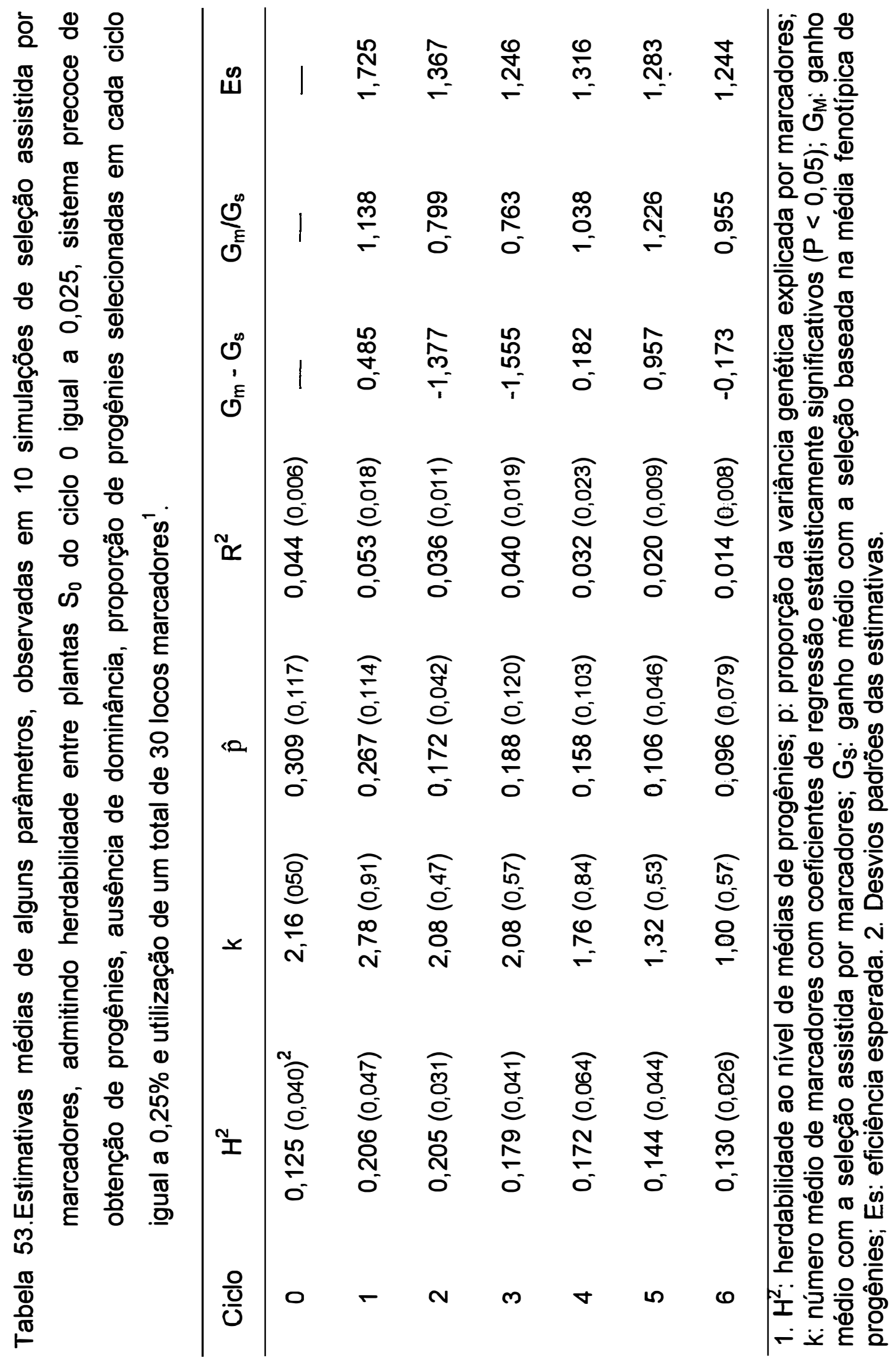




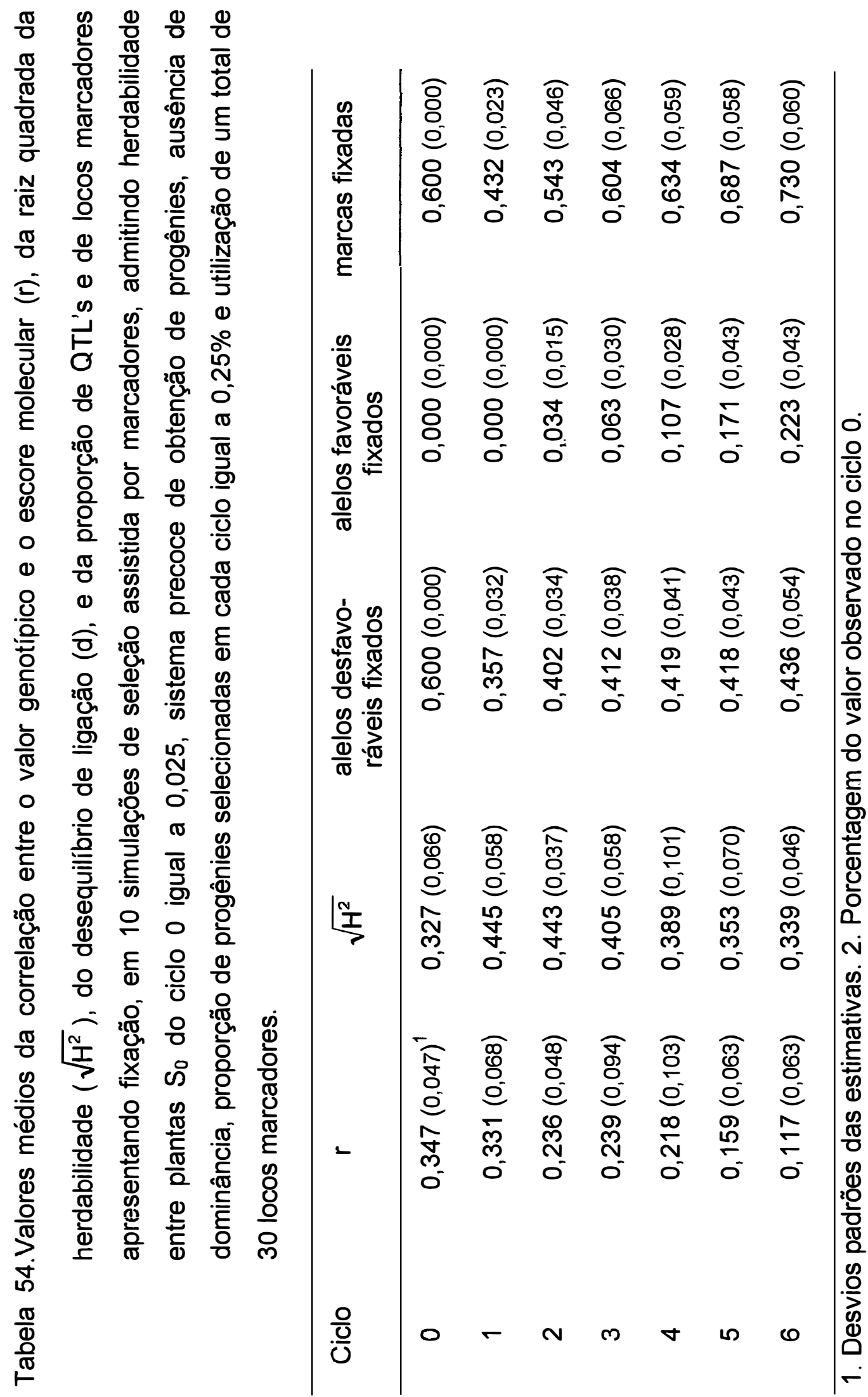




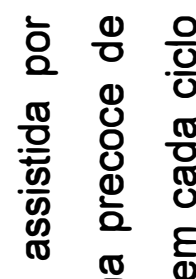

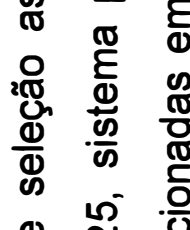

ข

a 0 㐫

.

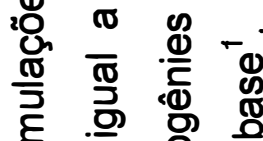

트 क응

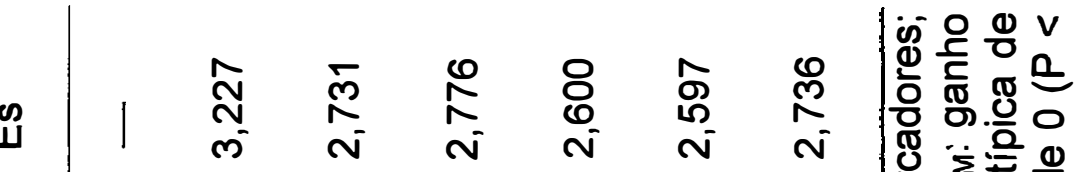

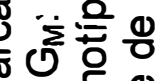
है. ๙

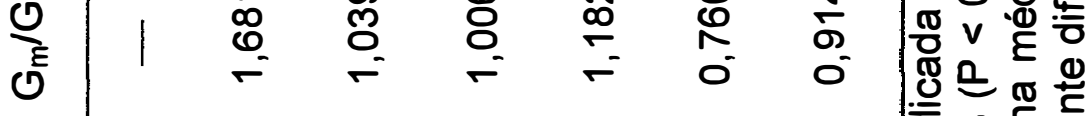
\%

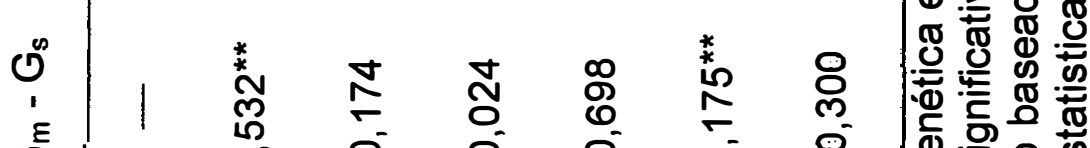
OE

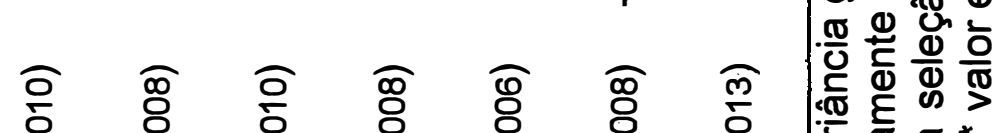
으 은 윰

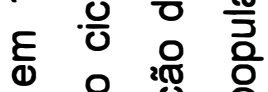
응 तั क 응

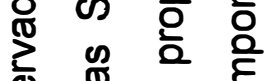
蛋

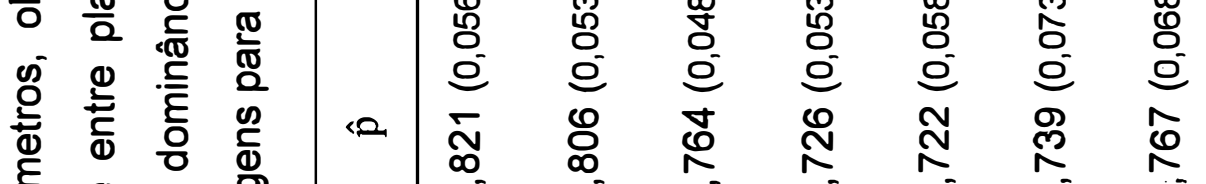

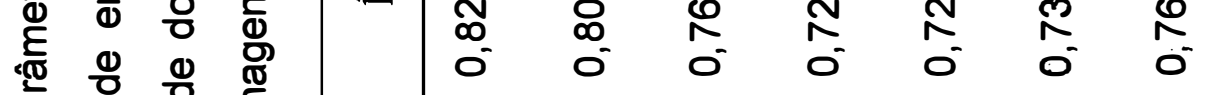
范 吾高要 का

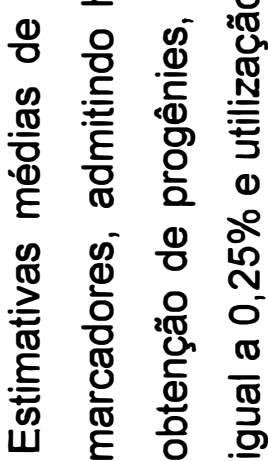
出

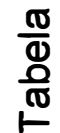

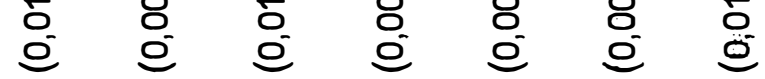

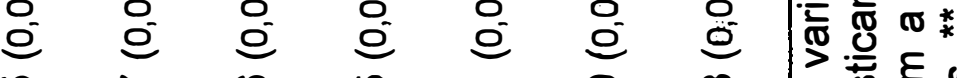
응 응 응 $\begin{array}{lllllll}0 & 0 & 0 & 0 & 0 & 0 & 0\end{array}$ 每

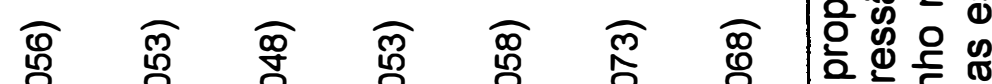
更 a is 0 i

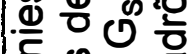
(1)

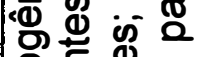
ह

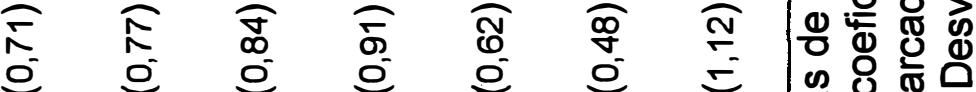

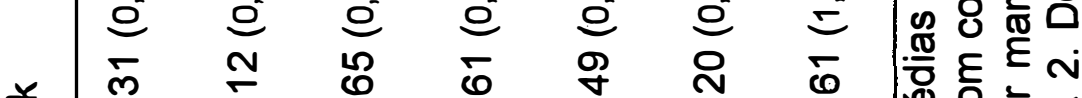

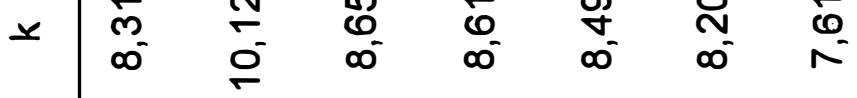
送 \% I

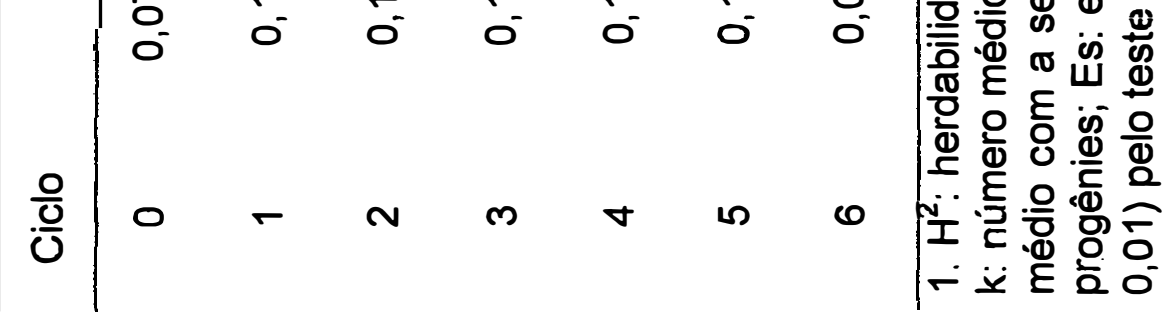




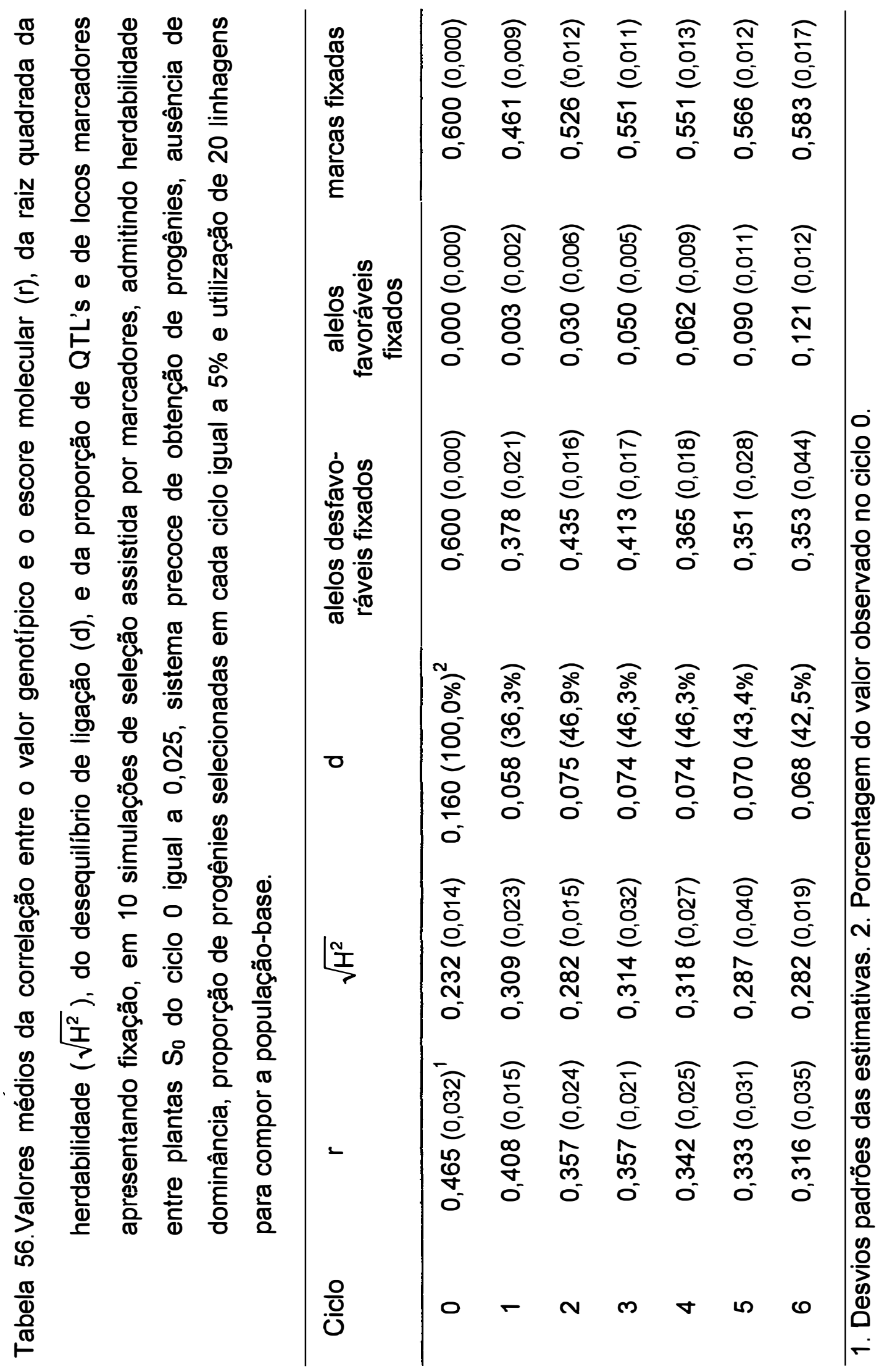


APÊNDICE 2

(FIGURAS) 

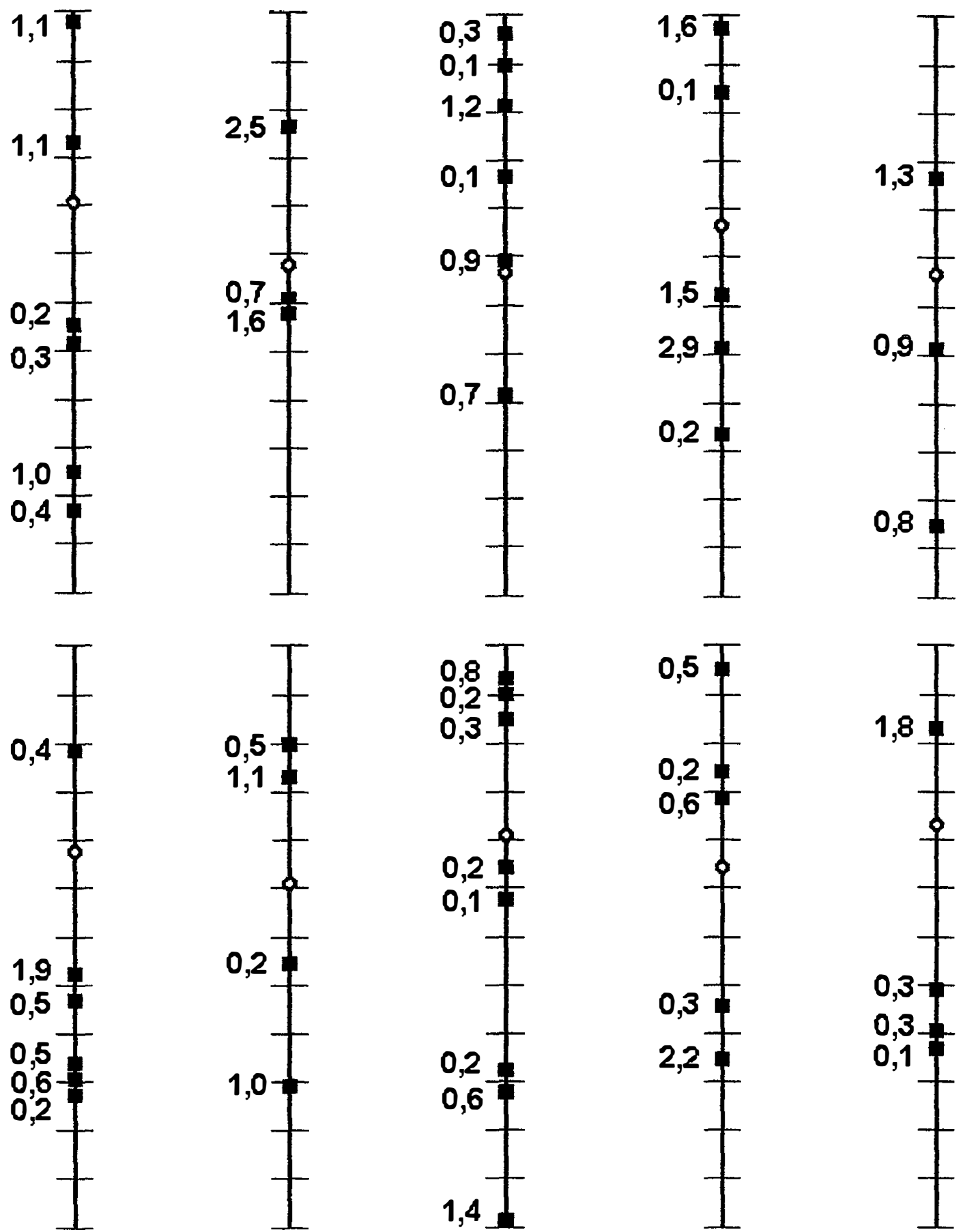

Figura 1. Mapa genético de um genoma simulado, com a posição (ఉ) e o efeito aditivo de 50 QTL's distribuídos aleatoriamente ao longo de 10 cromossomas, bem como a disposição sistemática de 130 locos marcadores $(-)$, e a localização de centrômeros $(0)$. Cada cromossomo possui $1 \mathrm{M}$ de comprimento. 


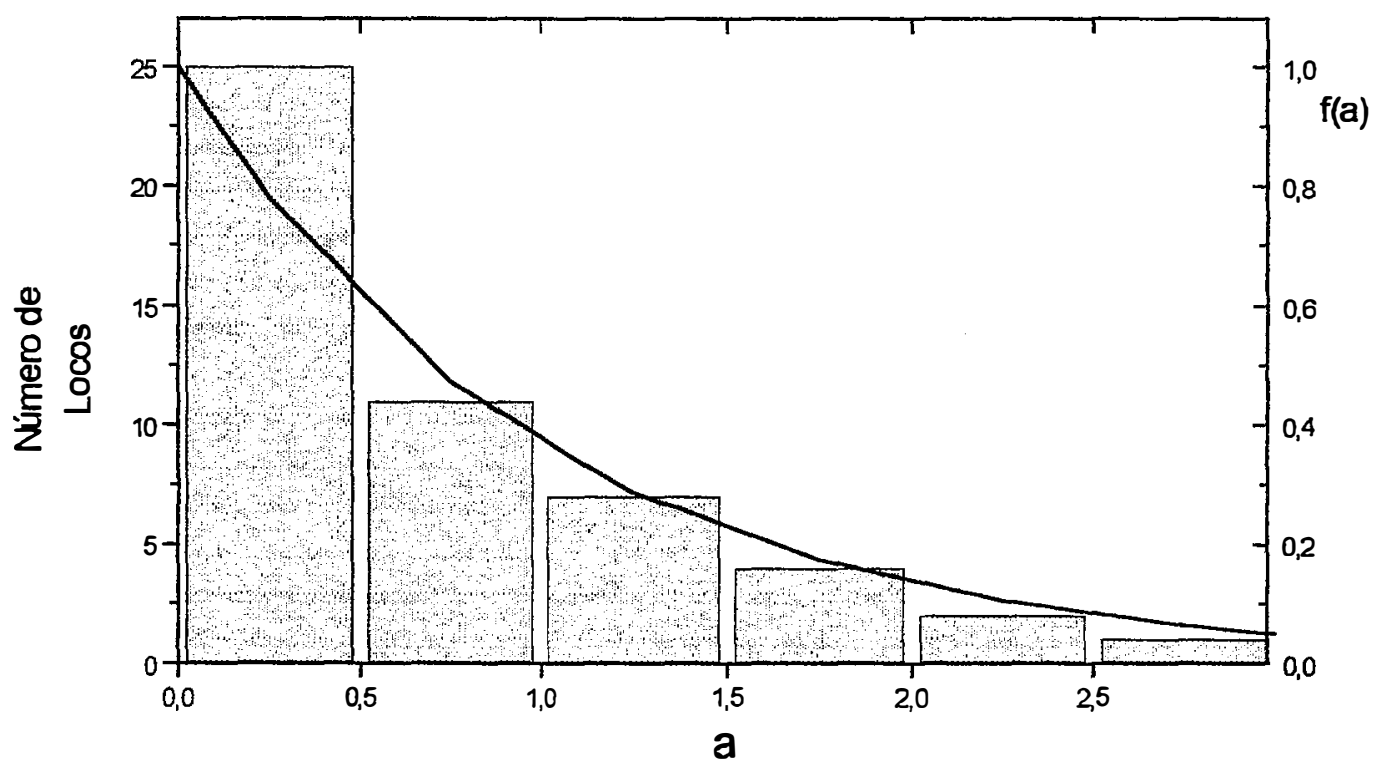

Figura 2. Função densidade de probabilidade exponencial com parâmetro igual a 1, e distribuição de frequência absoluta de efeitos aditivos (a) gerados aleatoriamente, conforme essa função. 


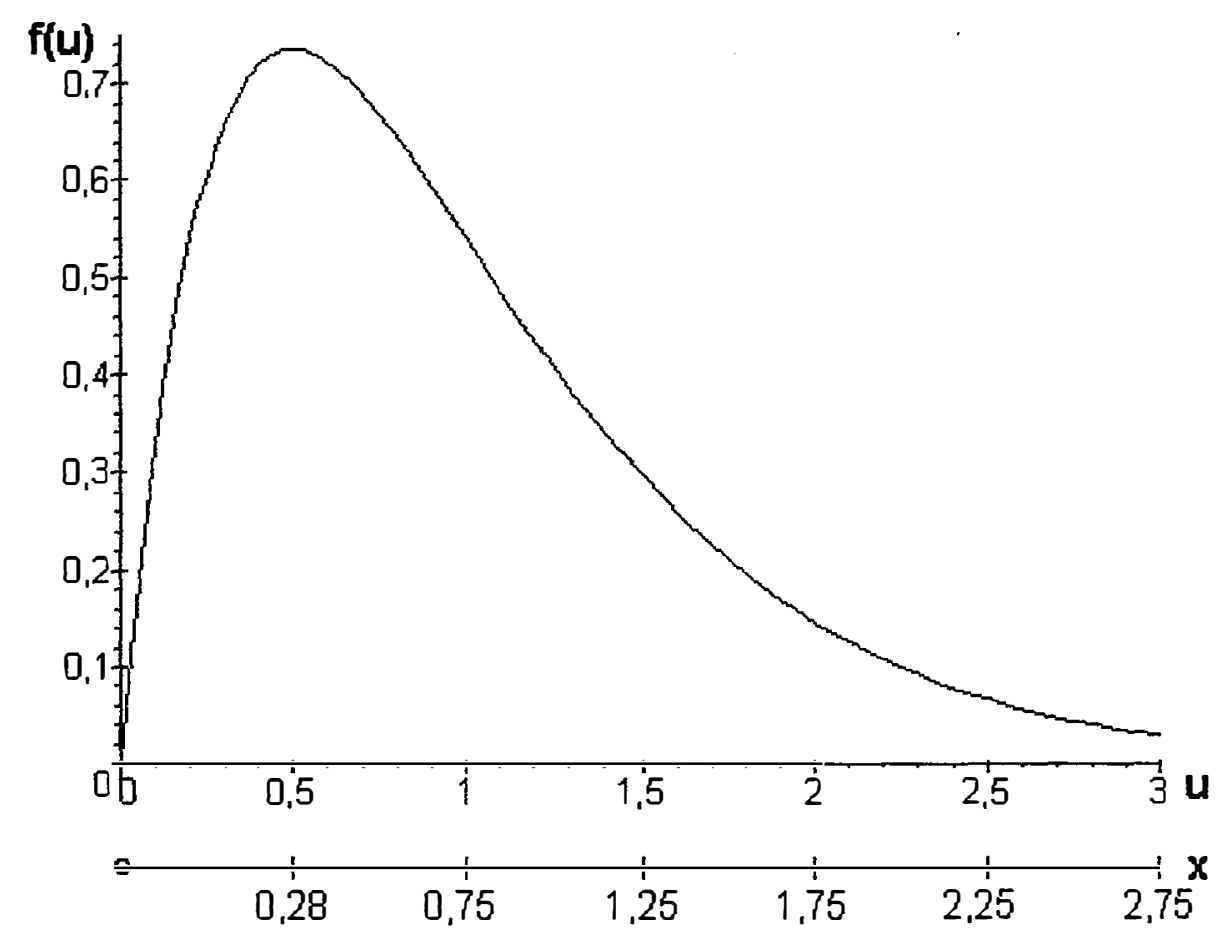

Figura 3. llustração da função de mapeamento proposta por Owen (1949) e sua correspondência com a escala expressa em Morgans ( $\mathrm{x}$ ). A origem de ambas corresponde à posição do centrômero, ou à do último ponto de permuta genética. 

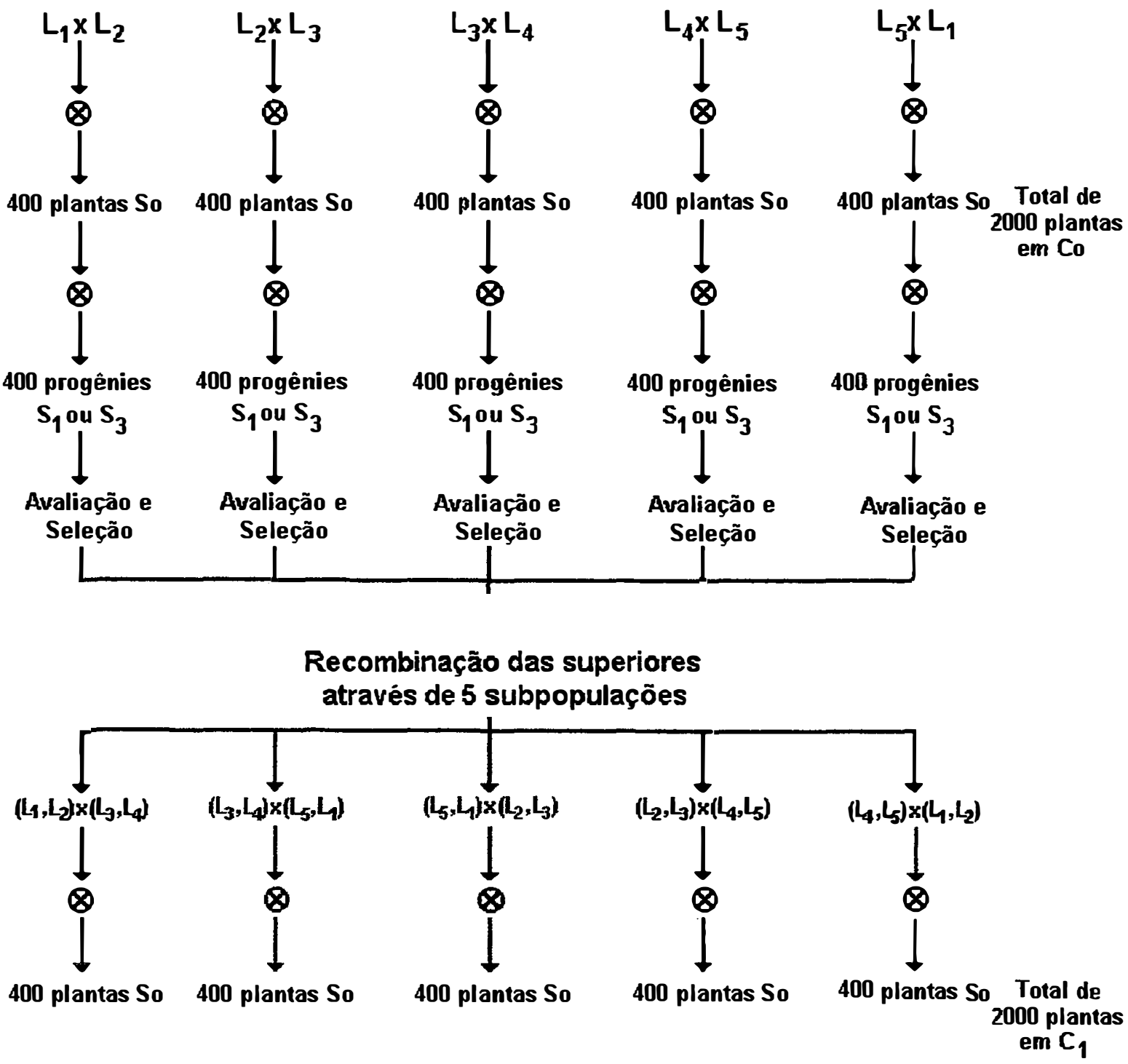

Figura 4. Representação do procedimento de formação da população base $\left(\mathrm{C}_{0}\right)$ para simular programas de seleção recorrente, a partir de 5 linhagens endogâmicas $L_{1}, L_{2}, L_{3}, L_{4}$ e $L_{5}$, compondo, em cruzamento, 5 subpopulações, e ilustração do procedimento para a realização de um ciclo seletivo ( $\otimes$ : autofecundação). 


$$
p=0,1
$$
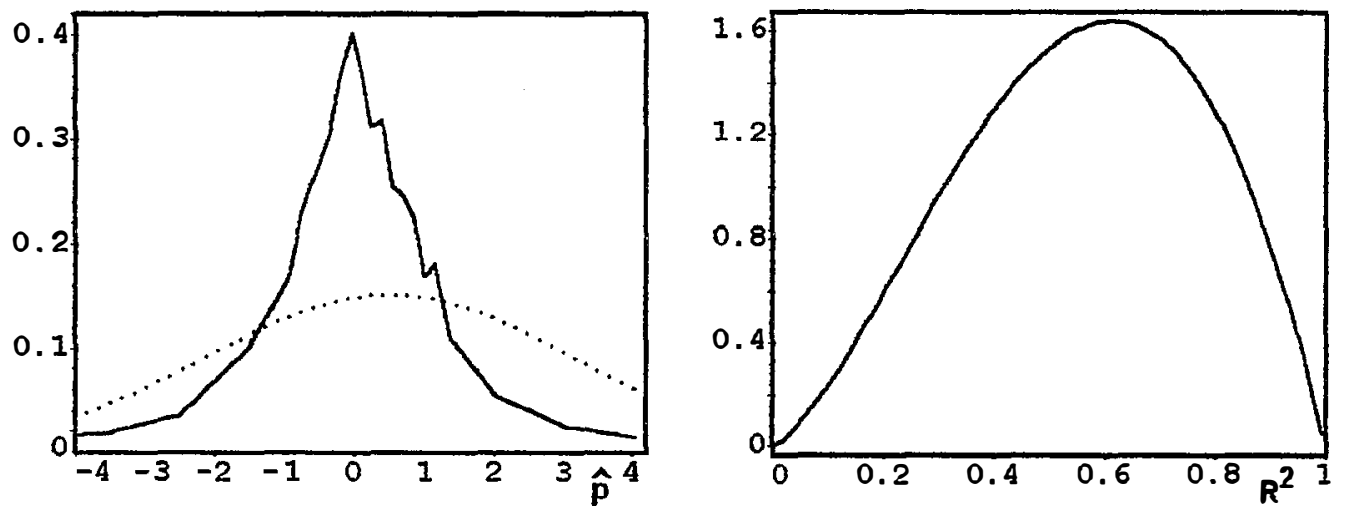

$$
p=0,9
$$
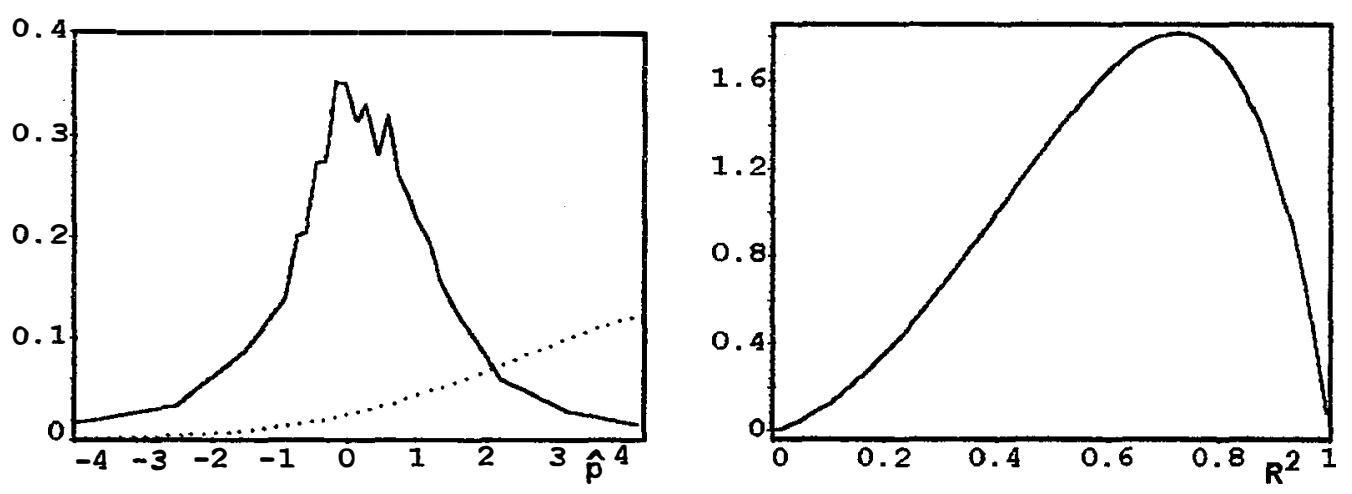

Figura 5. Distribuições de amostragem de $\hat{\mathrm{p}}$, obtidas a partir de simulações de Monte Carlo (linhas solidas), e da estatística $\mathrm{R}^{2}$, (linhas pontilhadas), considerando $t=10$ progênies, $k=5$ marcadores, $r=2$ repetições, $h^{2}=$ 0,2 , e diferentes valores de $p$. 


$$
p=0,1
$$
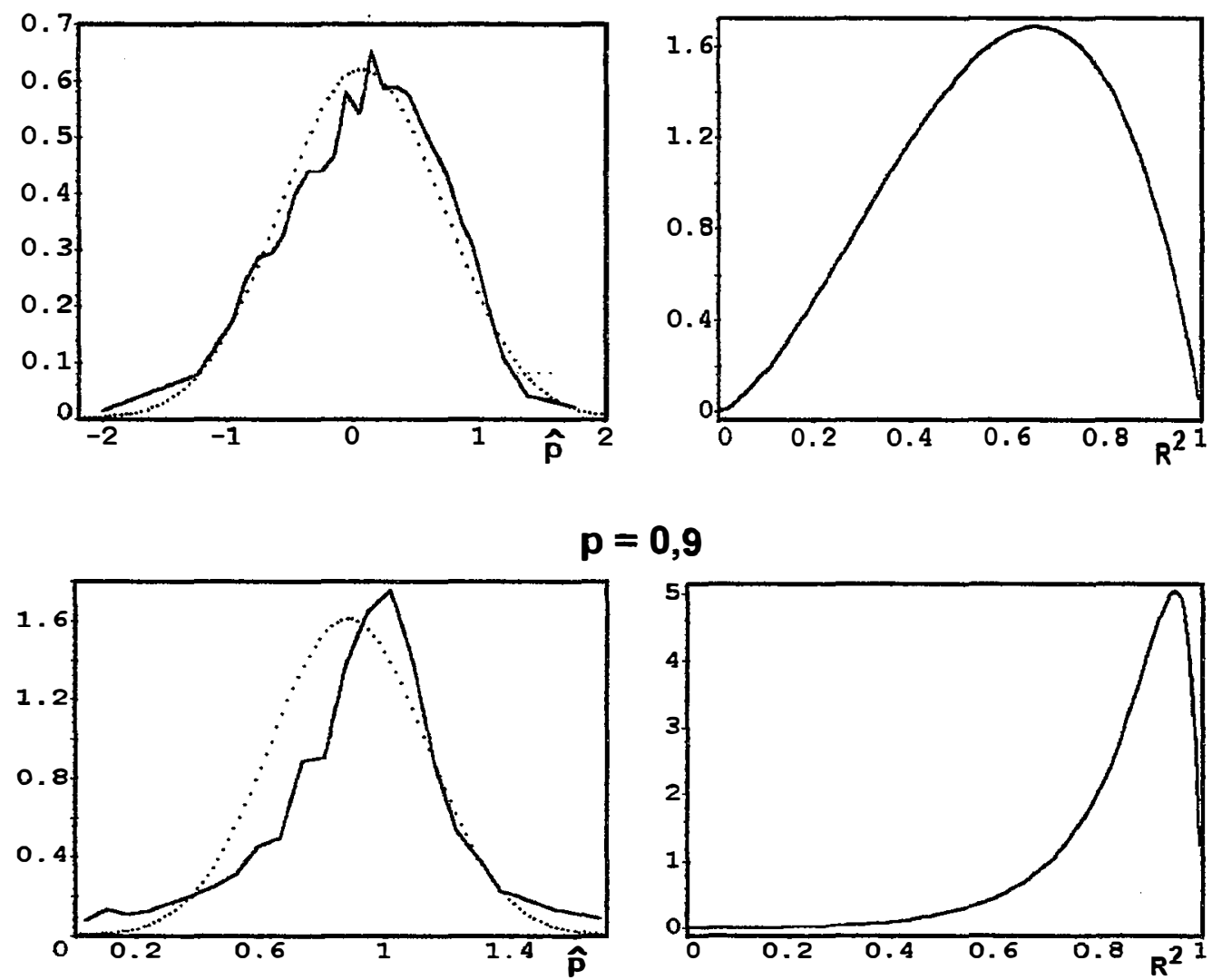

$p=0,9$

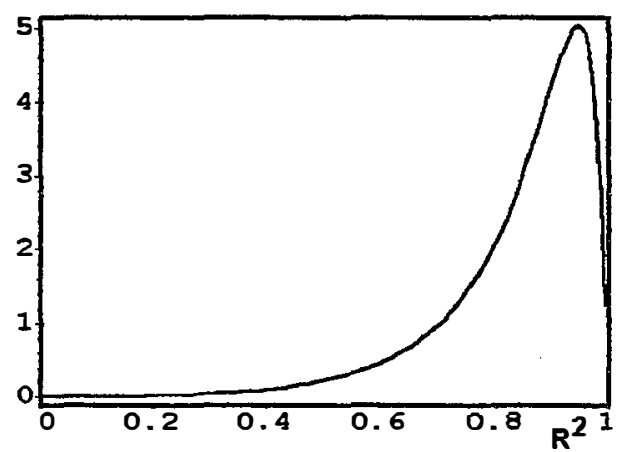

Figura 6. Distribuições de amostragem de $\hat{\mathrm{p}}$, obtidas a partir de simulações de Monte Carlo (linhas solidas), e da estatística $R^{2}$, (linhas pontilhadas), considerando $t=10$ progênies, $k=5$ marcadores, $r=2$ repetições, $h^{2}=$ 0,8 , e diferentes valores de $p$. 


$$
p=0,1
$$
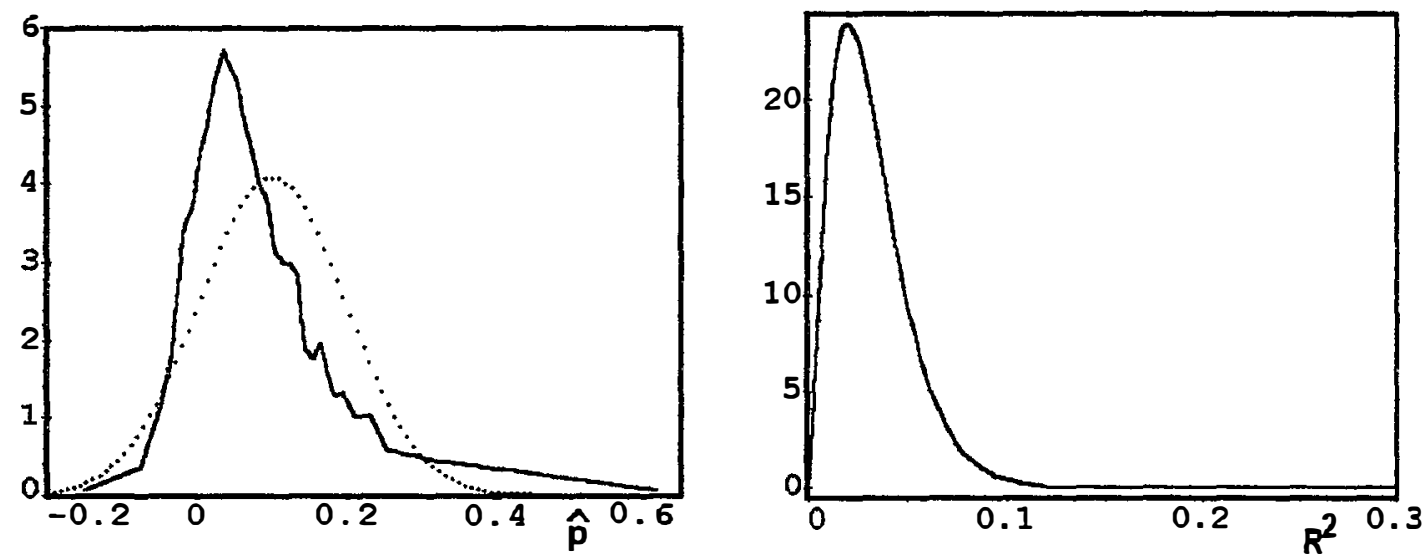

$$
p=0,9
$$
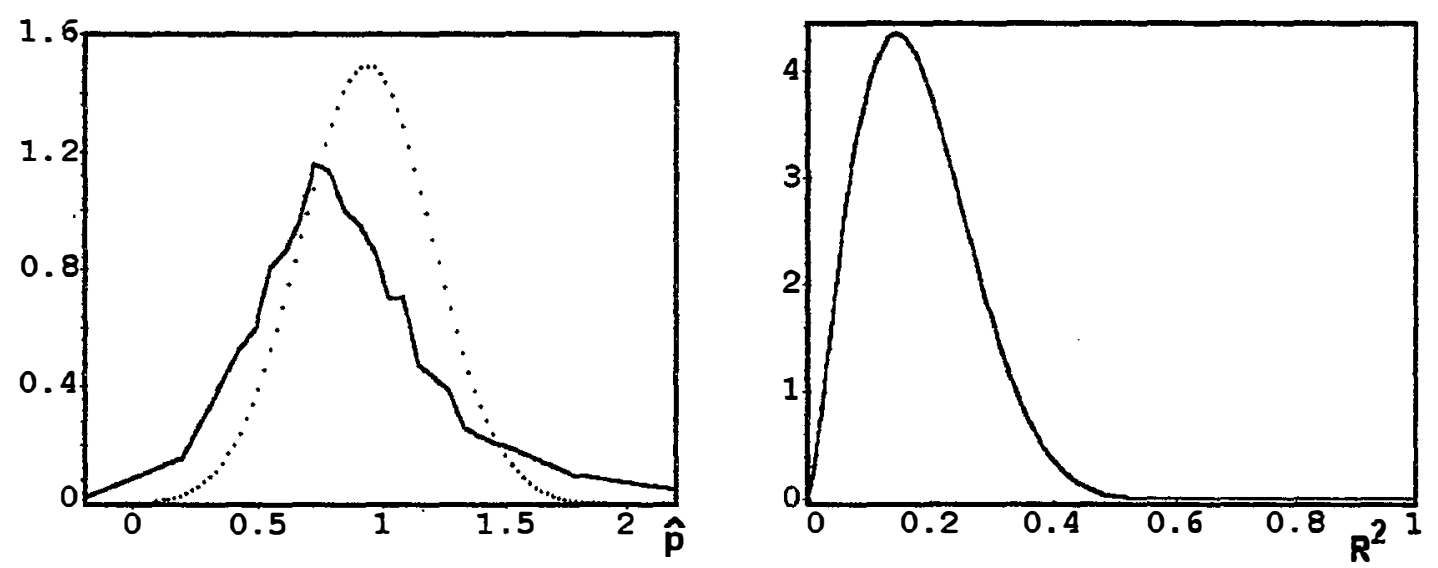

Figura 7. Distribuições de amostragem de $\hat{\mathrm{p}}$, obtidas a partir de simulações de Monte Carlo (linhas solidas), e da estatística $\mathrm{R}^{2}$, (linhas pontilhadas), considerando $t=400$ progênies, $k=5$ marcadores, $r=2$ repetiçöes, $h^{2}=0,2$, e diferentes valores de $p$. 
$b_{m}=40$
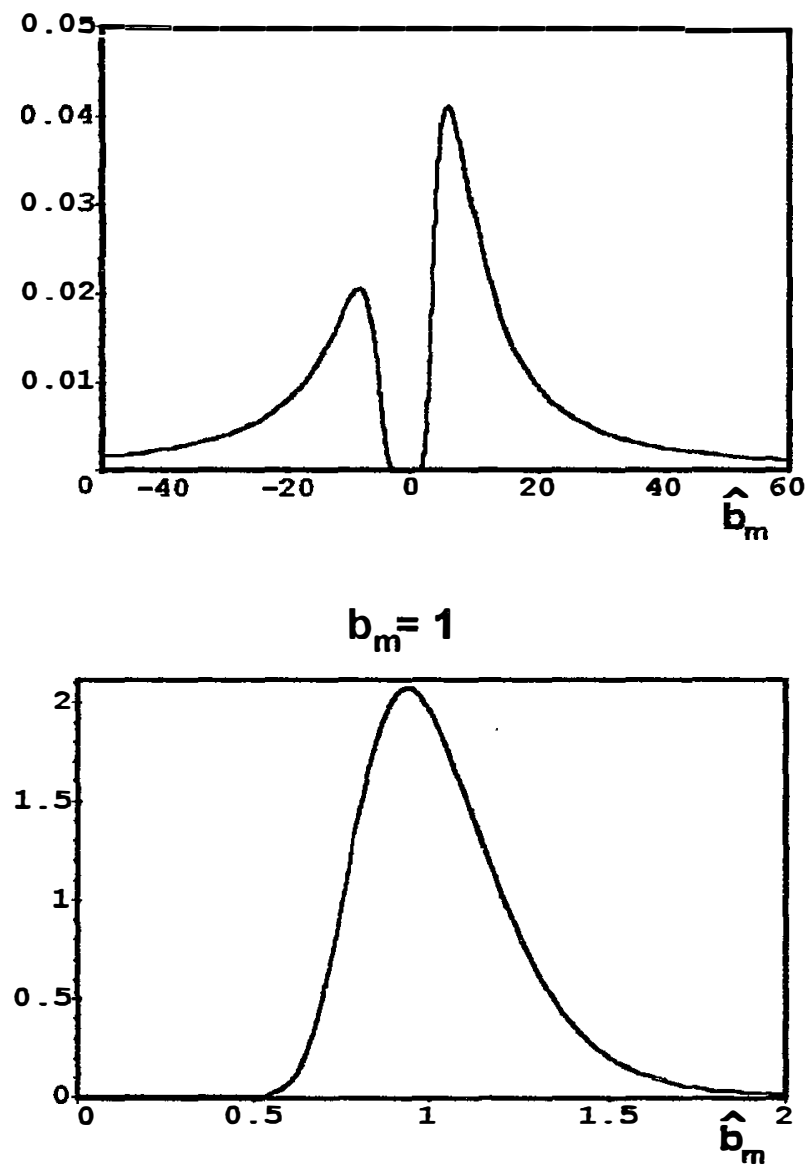

Figura 8. Distribuições de amostragem de $\hat{b}_{M}$, considerando um alto (40) e um baixo (1) valores de $b_{M}$. 


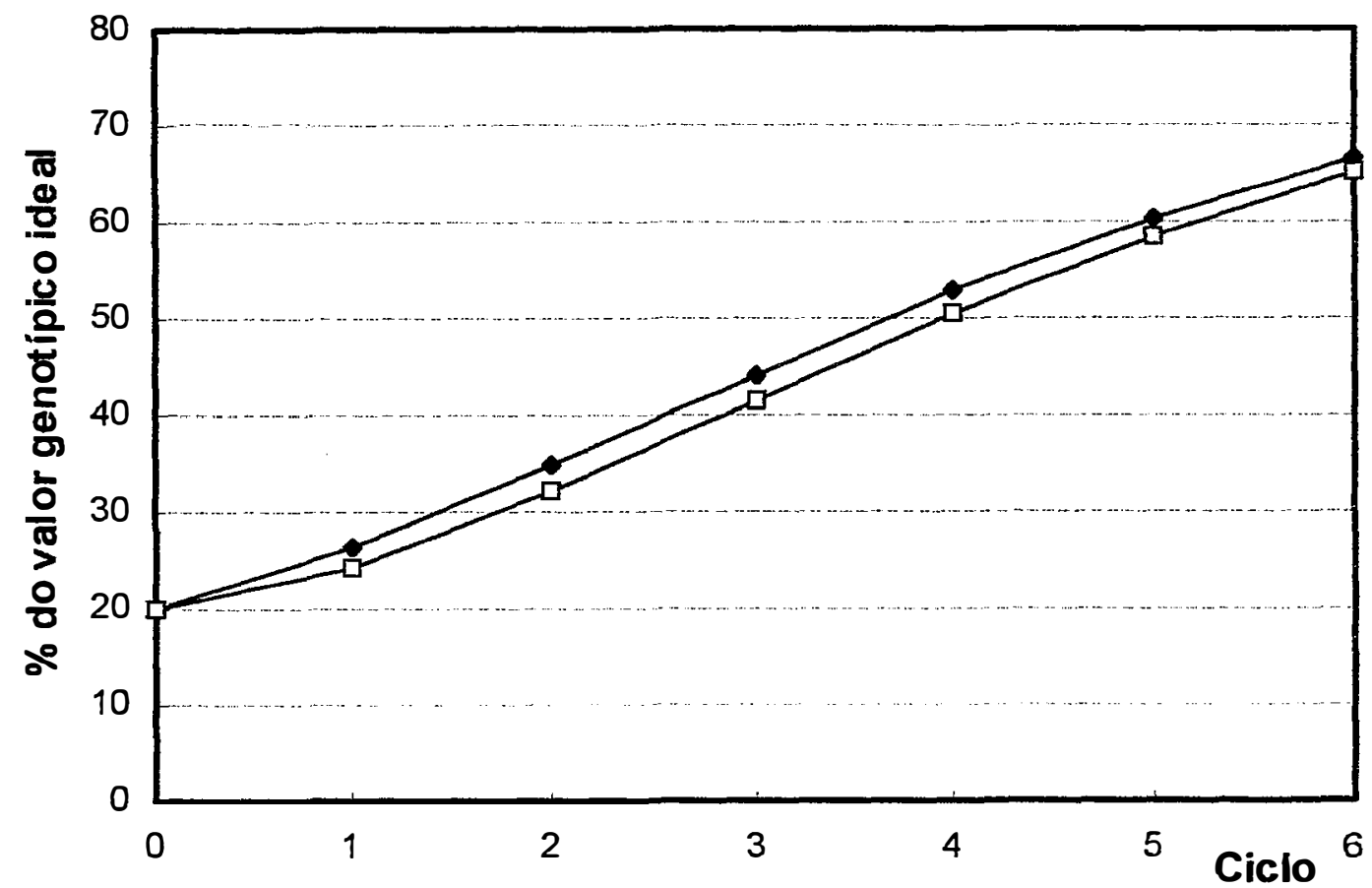

Figura 9. Respostas com a seleção assistida por marcadores ( $)$ e com a seleção baseada na média fenotípica de progênies $(\square)$, expressas em porcentagem do valor genotípico ideal (alelos favoráveis fixados em todos os locos), na simulação de 6 ciclos seletivos em computador, admitindo herdabilidade entre plantas $S_{0}$ igual a 0,050 , sistema precoce de obtenção de progênies, ausência de dominância, e proporção de progênies selecionadas por ciclo igual a $5 \%$. 


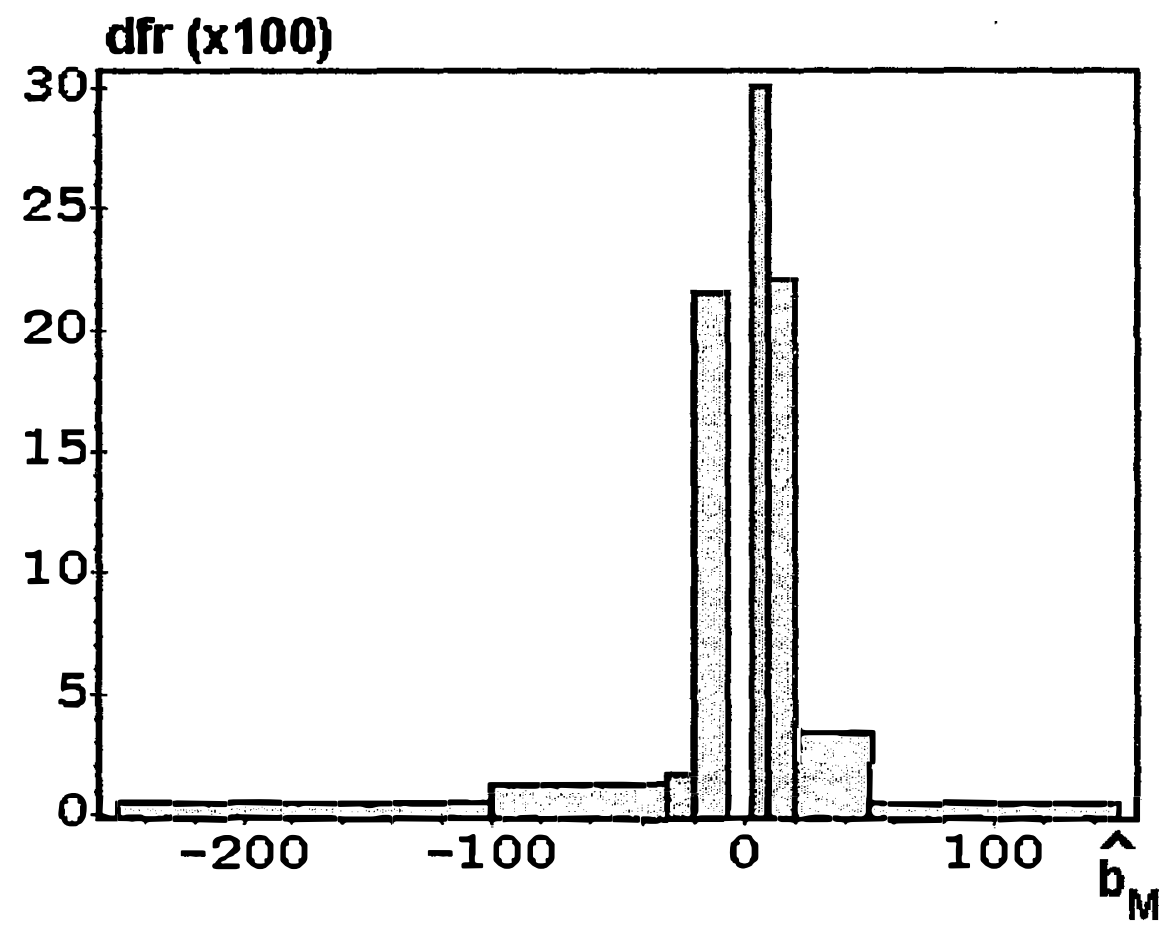

Figura 10. Distribuição de amostragem de $\hat{b}_{M}$, observada no ciclo 0 de 10 simulações de seleção assistida por marcadores, admitindo herdabilidade entre plantas $S_{0}$ igual a 0,05 e sistema precoce de obtenção de progênies (dfr $=$ densidade de frequência relativa). 


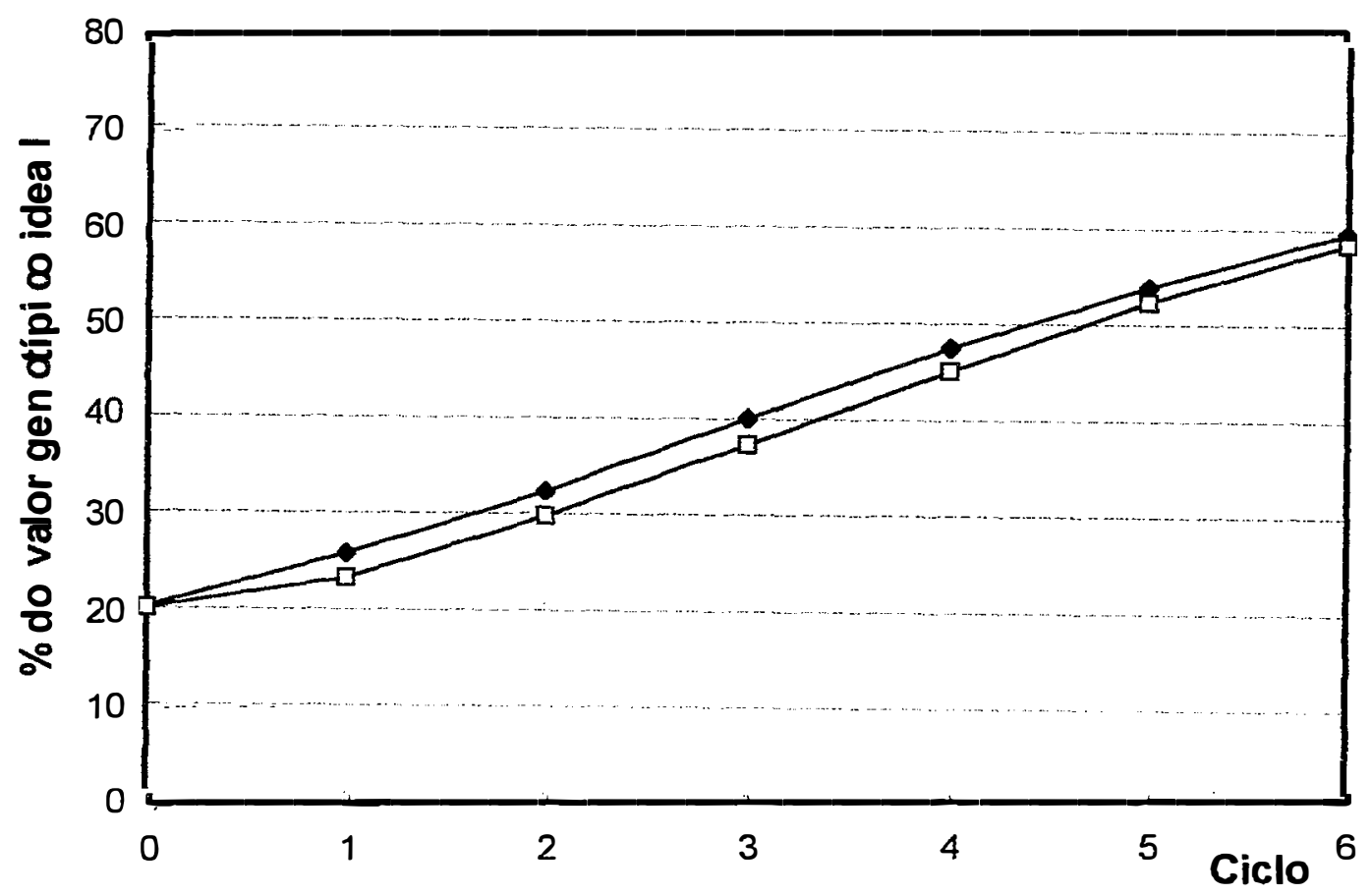

Figura 11. Respostas com a seleção assistida por marcadores $(\nabla)$ e com a seleção baseada na média fenotípica de progênies $(\square)$, expressas em porcentagem do valor genotípico ideal (alelos favoráveis fixados em todos os locos), na simulação de 6 ciclos seletivos em computador, admitindo herdabilidade entre plantas $S_{0}$ igual a 0,025 , sistema precoce de obtenção de progênies, ausência de dominância, e proporção de progênies selecionadas por ciclo igual a $5 \%$. 


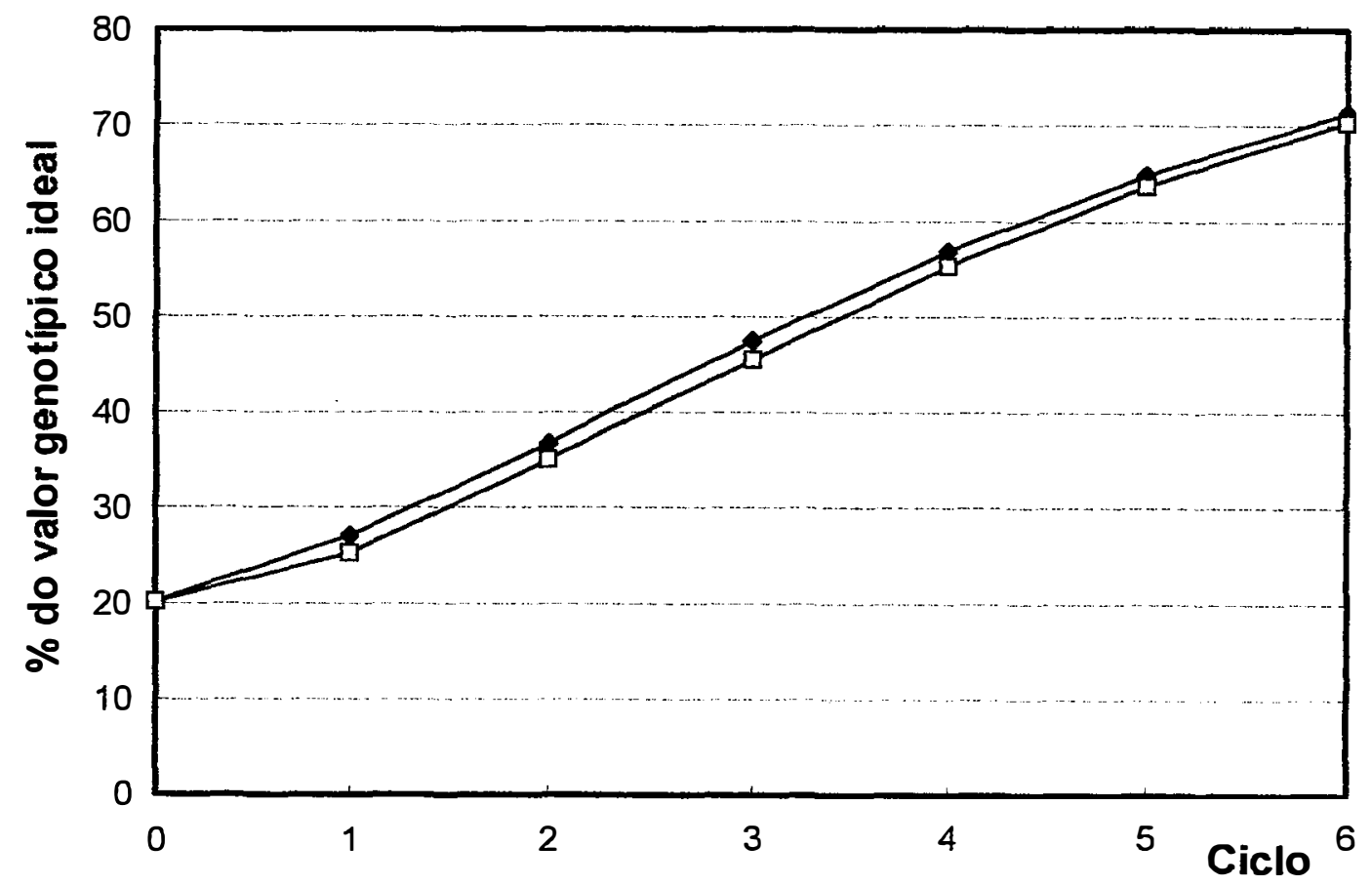

Figura 12. Respostas com a seleção assistida por marcadores ( $)$ e com a seleção baseada na média fenotípica de progênies ( $\square$ ), expressas em porcentagem do valor genotípico ideal (alelos favoráveis fixados em todos os locos), na simulação de 6 ciclos seletivos em computador, admitindo herdabilidade entre plantas $S_{0}$ igual a 0,1 , sistema precoce de obtenção de progênies, ausência de dominância, e proporção de progênies selecionadas por ciclo igual a $5 \%$. 


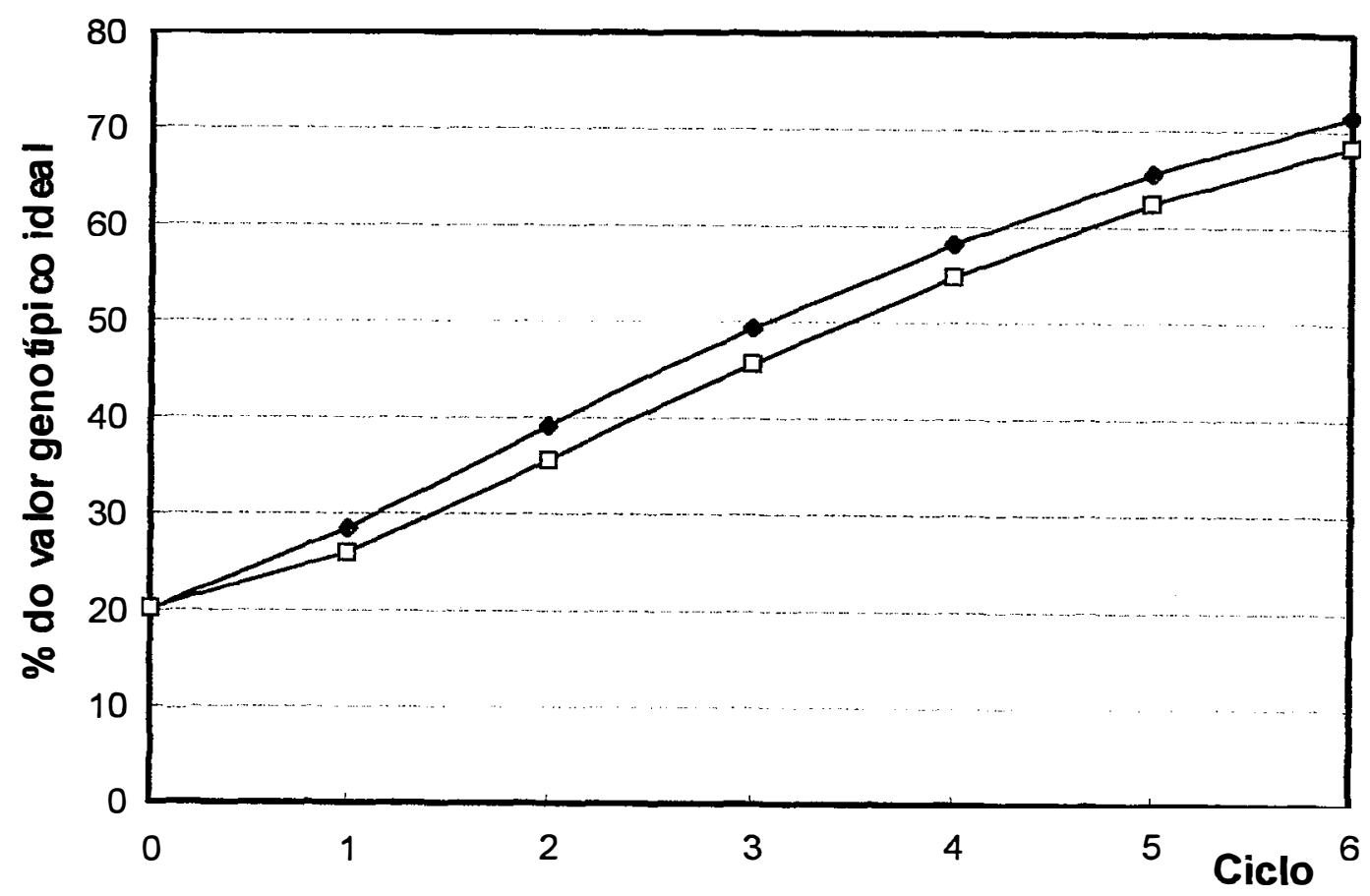

Figura 13. Respostas com a seleção assistida por marcadores $(\nabla)$ e com a seleção baseada na média fenotípica de progênies $(\square)$, expressas em porcentagem do valor genotípico ideal (alelos favoráveis fixados em todos os locos), na simulação de 6 ciclos seletivos em computador, admitindo herdabilidade entre plantas $S_{0}$ igual a 0,025, sistema avançado de obtenção de progênies, ausência de dominância, e proporção de progênies selecionadas por ciclo igual a $5 \%$. 


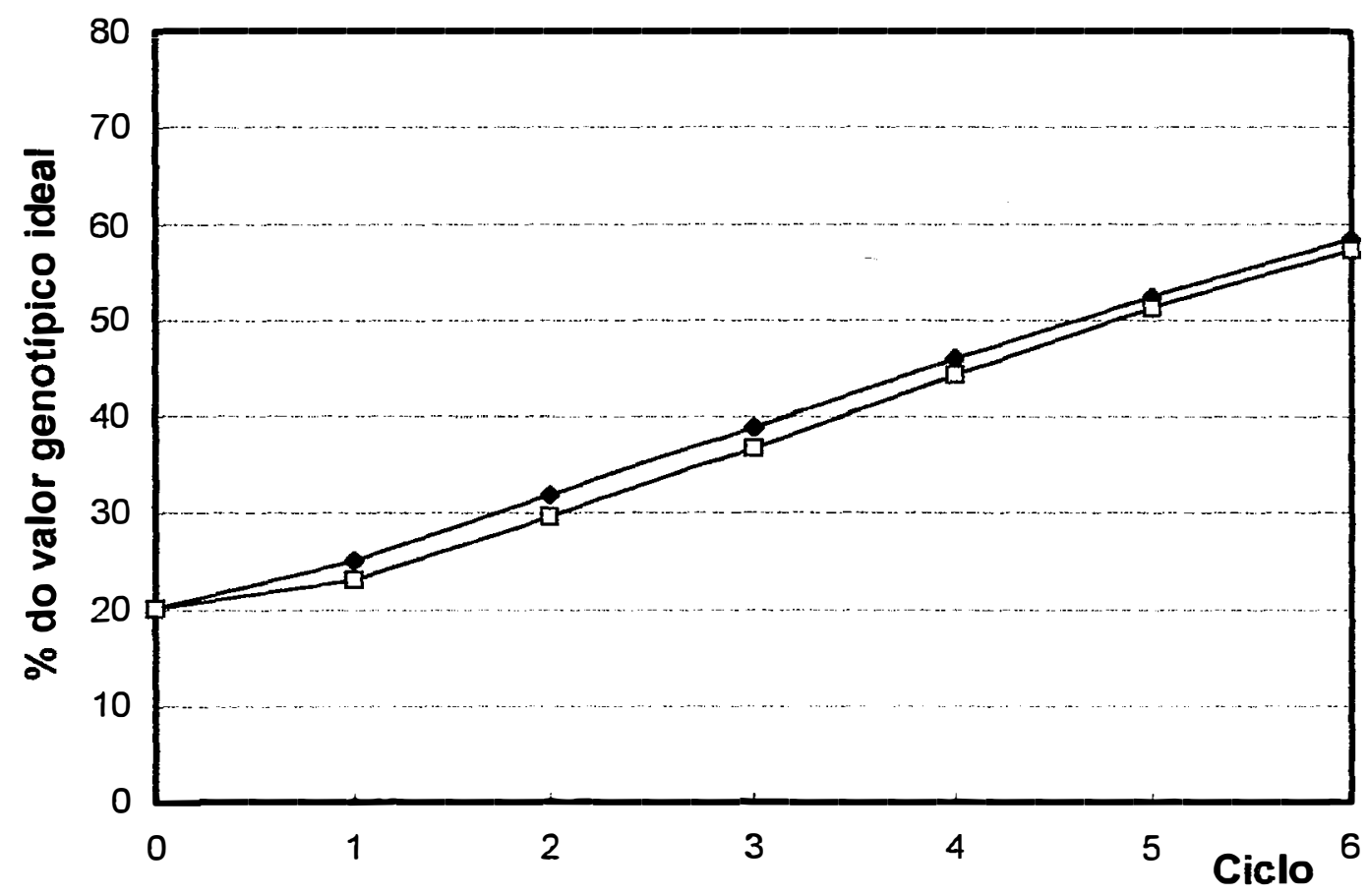

Figura 14. Respostas com a seleção assistida por marcadores $(\nabla)$ e com a seleção baseada na média fenotípica de progênies ( $\square$ ), expressas em porcentagem do valor genotípico ideal (alelos favoráveis fixados em todos os locos), na simulação de 6 ciclos seletivos em computador, admitindo herdabilidade entre plantas $S_{0}$ igual a 0,025, sistema precoce de obtenção de progênies, ausência de dominância, proporção de progênies selecionadas por ciclo igual a $5 \%$ e um total de 300 progênies avaliadas por cruzamento em cada ciclo. 


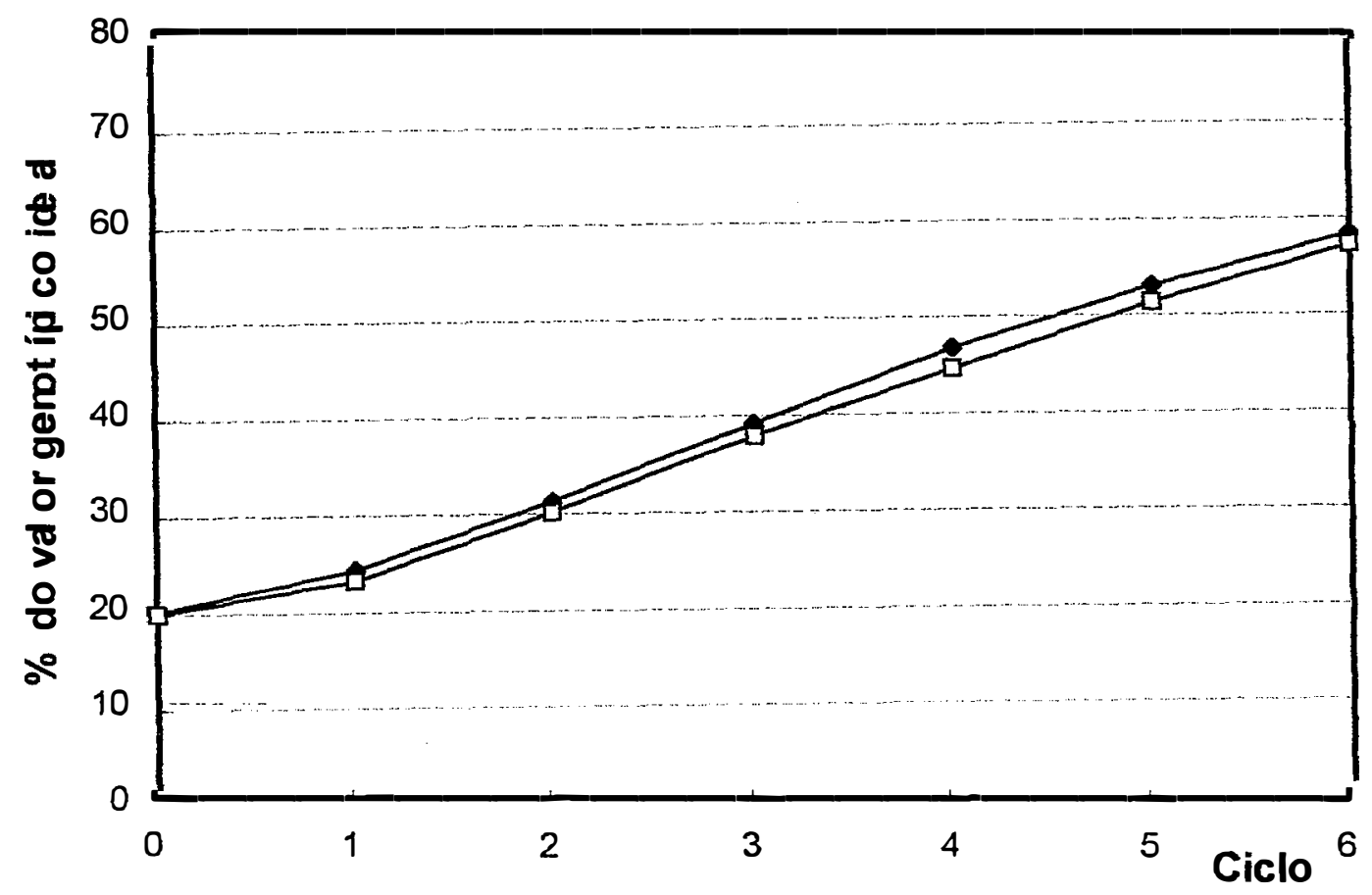

Figura 15. Respostas com a seleção assistida por marcadores $(\nabla)$ e com a seleção baseada na média fenotípica de progênies ( $\square)$, expressas em porcentagem do valor genotípico ideal (alelos favoráveis fixados em todos os locos), na simulação de 6 ciclos seletivos em computador, admitindo herdabilidade entre plantas $S_{0}$ igual a 0,025 , sistema precoce de obtenção de progênies, ausência de dominância, proporção de progênies selecionadas por ciclo igual a $5 \%$ e um total de 160 progênies avaliadas por cruzamento em cada ciclo. 


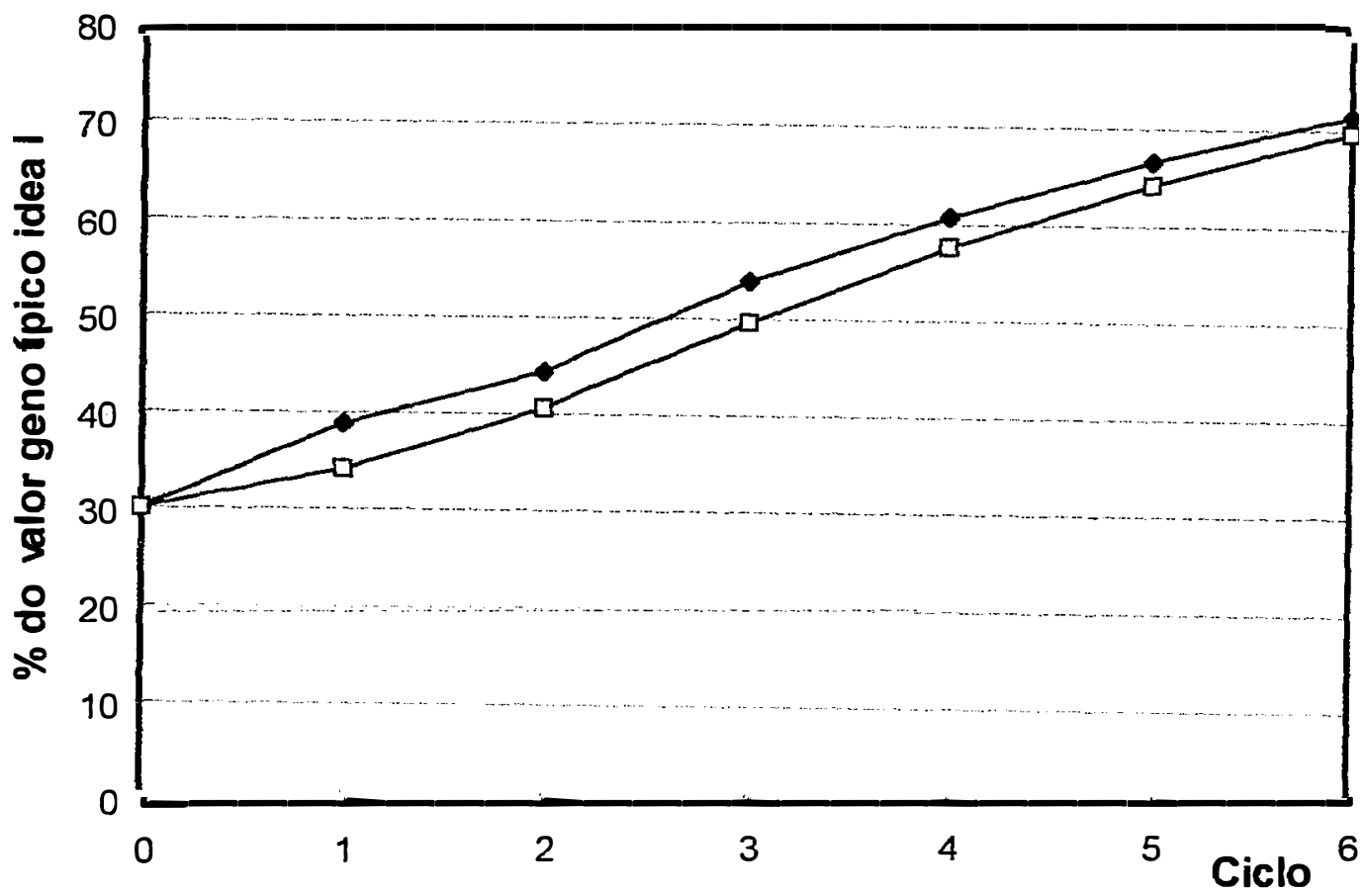

Figura 16. Respostas com a seleção assistida por marcadores ( $)$ e com a seleção baseada na média fenotípica de progênies $(\square)$, expressas em porcentagem do valor genotípico ideal (alelos favoráveis fixados em todos os locos), na simulação de 6 ciclos śeletivos em computador, admitindo herdabilidade entre plantas $S_{0}$ igual a 0,05 , sistema precoce de obtenção de progênies, presença de dominância positiva completa, e proporção de progênies selecionadas por ciclo igual a $5 \%$. 


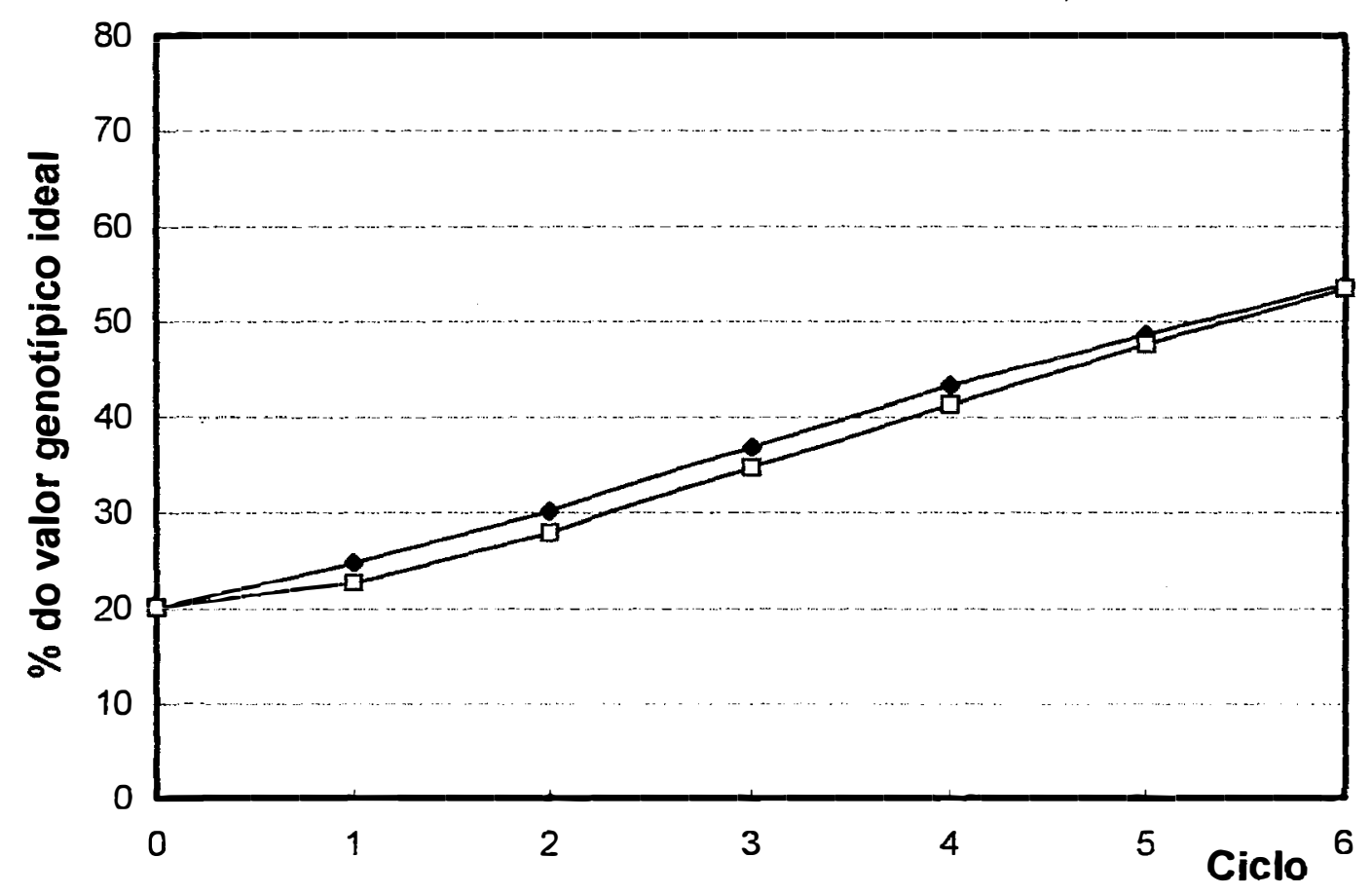

Figura 17. Respostas com a seleção assistida por marcadores ( $\bullet$ ) e com a seleção baseada na média fenotípica de progênies ( $\square$ ), expressas em porcentagem do valor genotípico ideal (alelos favoráveis fixados em todos os locos), na simulação de 6 ciclos seletivos em computador, admitindo herdabilidade entre plantas $S_{0}$ igual a 0,025 , sistema precoce de obtenção de progênies, ausência de dominância, e proporção de progênies selecionadas por ciclo igual a $10 \%$. 


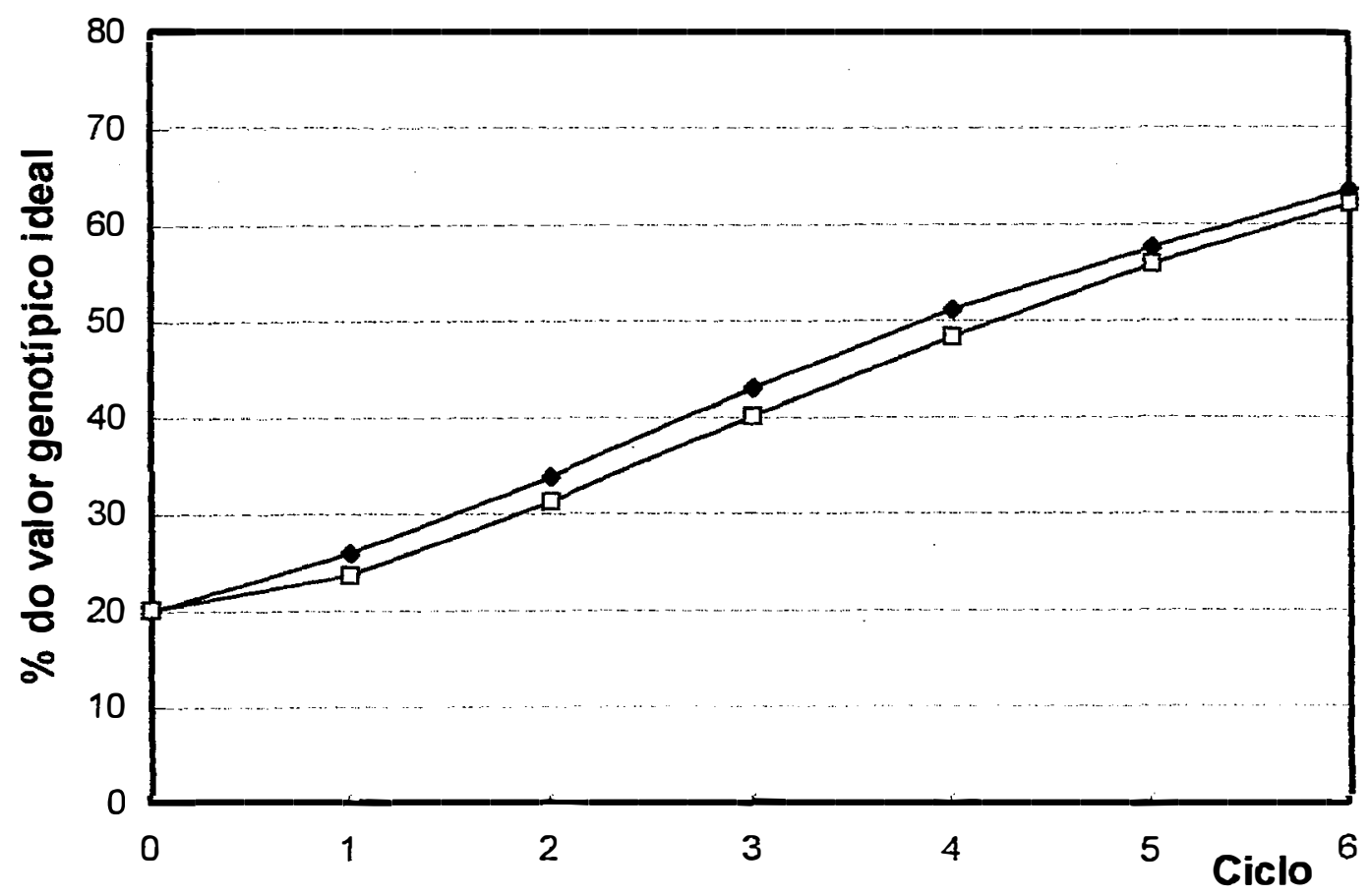

Figura 18. Respostas com a seleção assistida por marcadores $(\nabla)$ e com a seleção baseada na média fenotípica de progênies ( $\square$ ), expressas em porcentagem do valor genotípico ideal (alelos favoráveis fixados em todos os locos), na simulação de 6 ciclos seletivos em computador, admitindo herdabilidade entre plantas $S_{0}$ igual a 0,025 , sistema precoce de obtenção de progênies, ausência de dominância, e proporção de progênies selecionadas por ciclo igual a $2,5 \%$. 


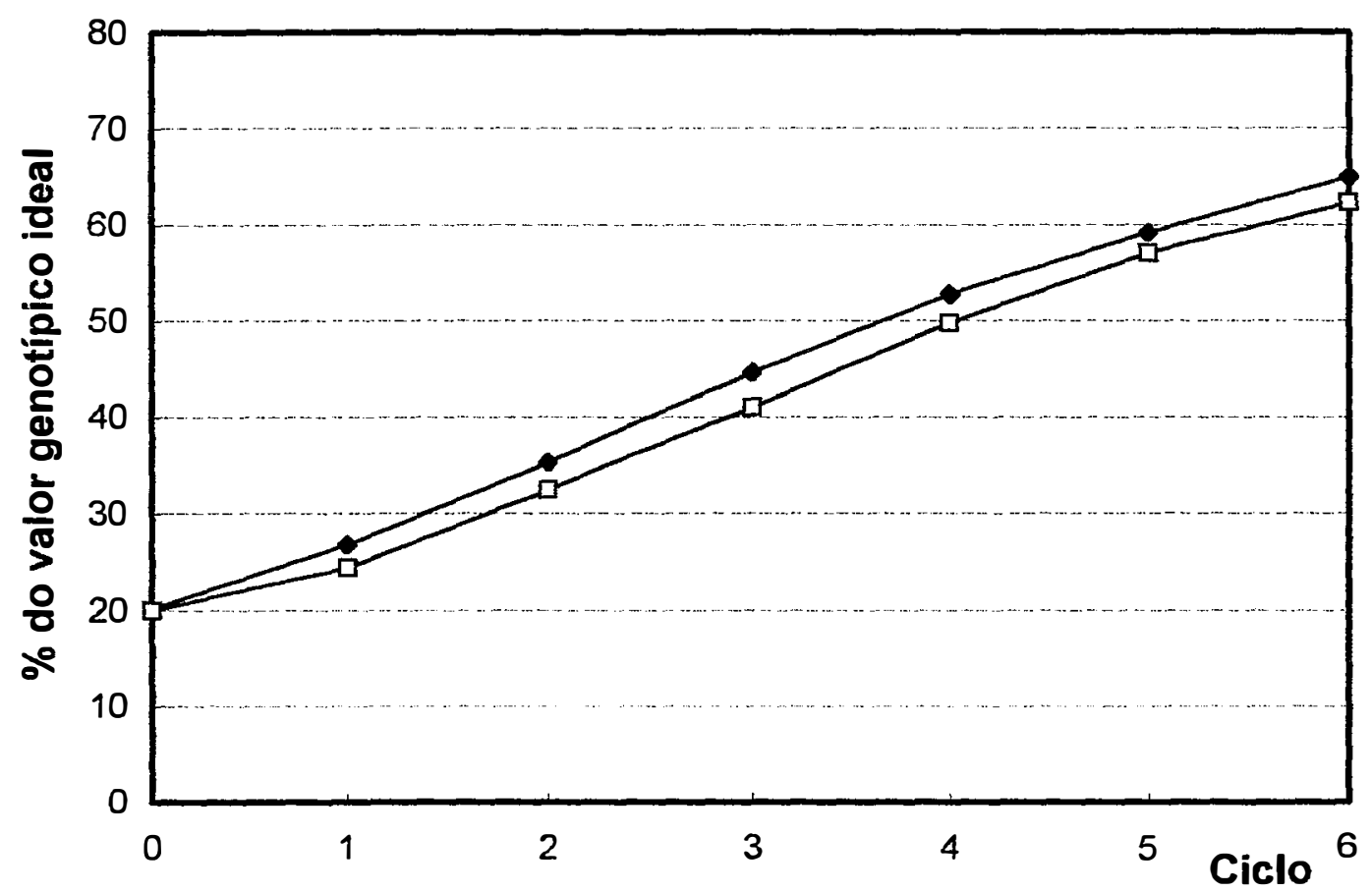

Figura 19. Respostas com a seleção assistida por marcadores $(\nabla)$ e com a seleção baseada na média fenotípica de progênies ( $\square$ ), expressas em porcentagem do valor genotípico ideal (alelos favoráveis fixados em todos os locos), na simulação de 6 ciclos seletivos em computador, admitindo herdabilidade entre plantas $S_{0}$ igual a 0,025 , sistema precoce de obtenção de progênies, ausência de dominância, e proporção de progênies selecionadas por ciclo igual a $1 \%$. 


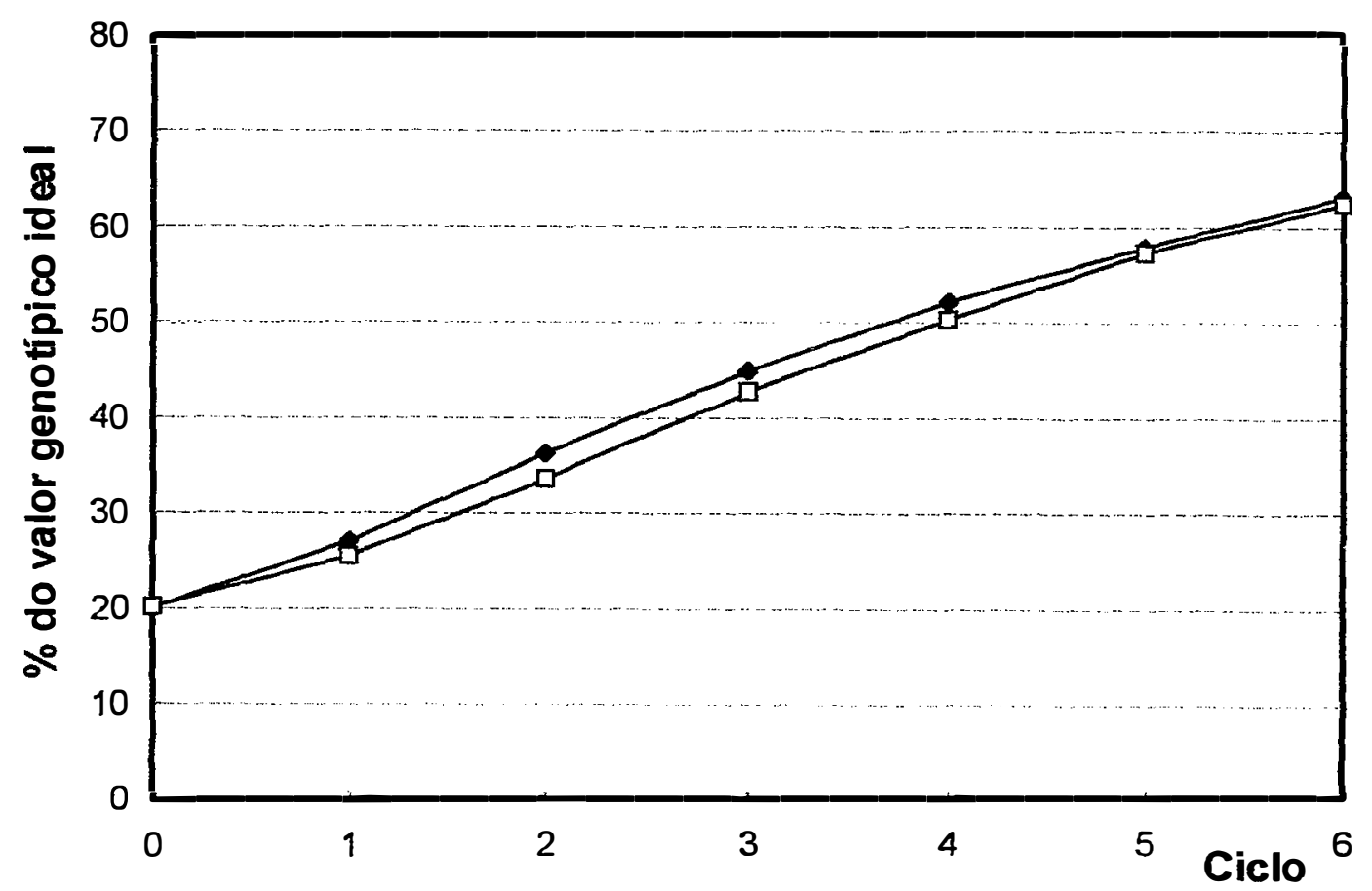

Figura 20. Respostas com a seleção assistida por marcadores $(\nabla)$ e com a seleção baseada na média fenotípica de progênies ( $\square$ ), expressas em porcentagem do valor genotípico ideal (alelos favoráveis fixados em todos os locos), na simulação de 6 ciclos seletivos em computador, admitindo herdabilidade entre plantas $S_{0}$ igual a 0,025 , sistema precoce de obtenção de progênies, ausência de dominância, e proporção de progênies selecionadas por ciclo igual a $0,25 \%$. 


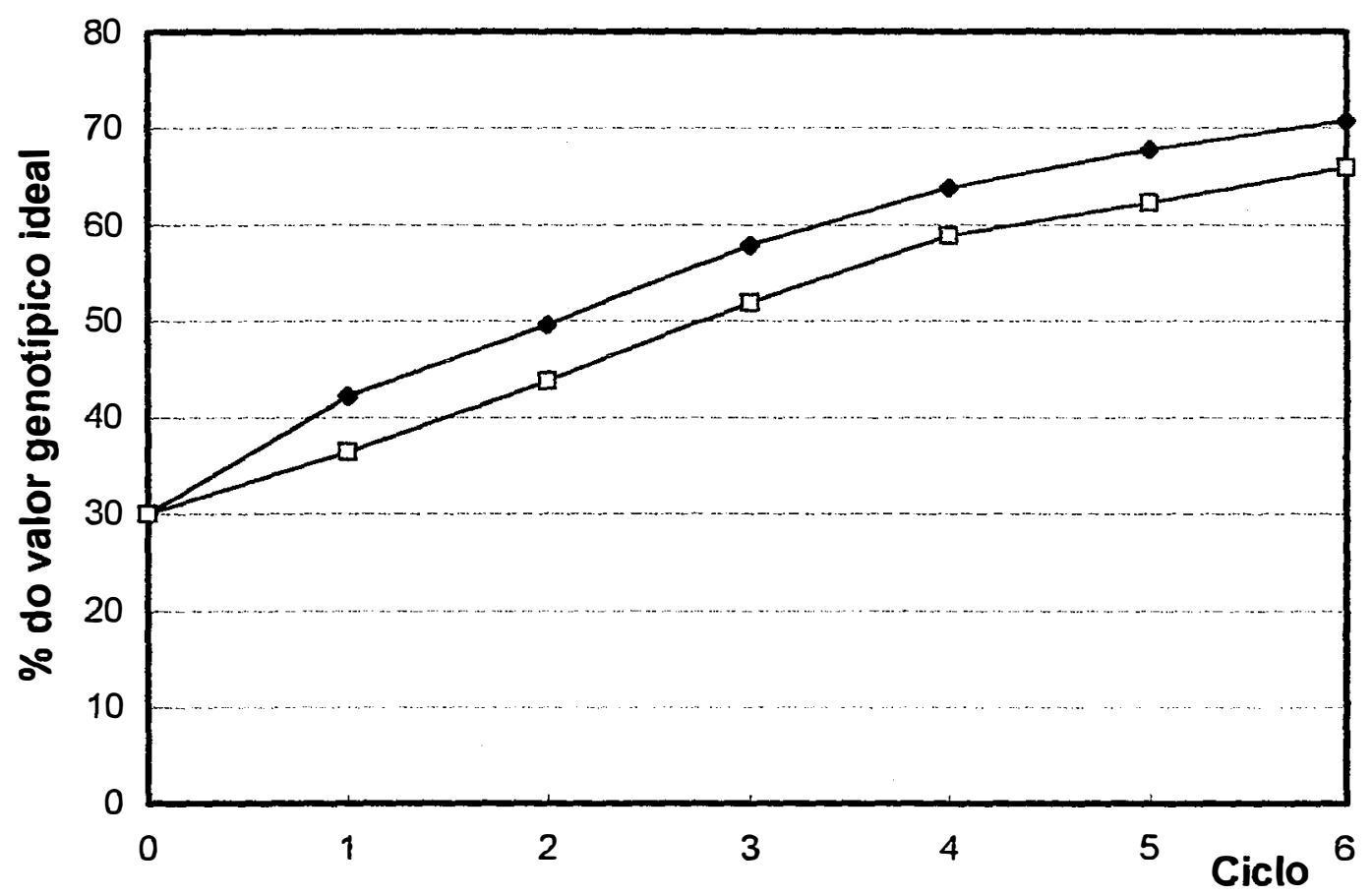

Figura 21. Respostas com a seleção assistida por marcadores ( ) e com a seleção baseada na média fenotípica de progênies ( $\square$ ), expressas em porcentagem do valor genotípico ideal (alelos favoráveis fixados em todos os locos), na simulação de 6 ciclos seletivos em computador, admitindo herdabilidade entre plantas $S_{0}$ igual a 0,05 , sistema precoce de obtenção de progênies, presença de dominância positiva completa, e proporção de progênies selecionadas por ciclo igual a $0,25 \%$. 


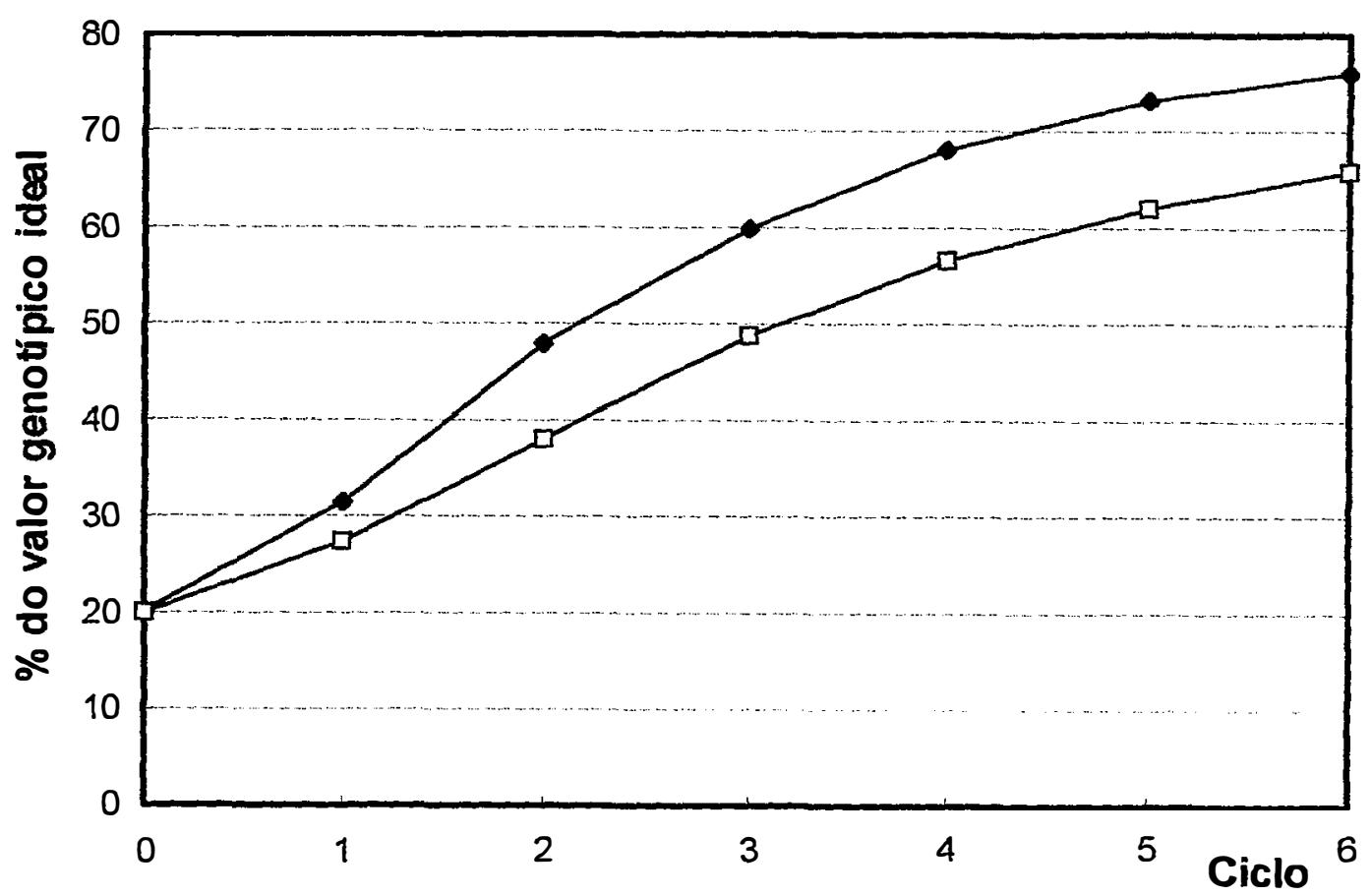

Figura 22. Respostas com a seleção assistida por marcadores ( $\downarrow$ ) e com a seleção baseada na média fenotípica de progênies ( $\square$ ), expressas em porcentagem do valor genotípico ideal (alelos favoráveis fixados em todos os locos), na simulação de 6 ciclos seletivos em computador, admitindo herdabilidade entre plantas $S_{0}$ igual a 0,025 , sistema avançado de obtenção de progênies, ausência de dominância, e proporção de progênies selecionadas por ciclo igual a $0,25 \%$. 


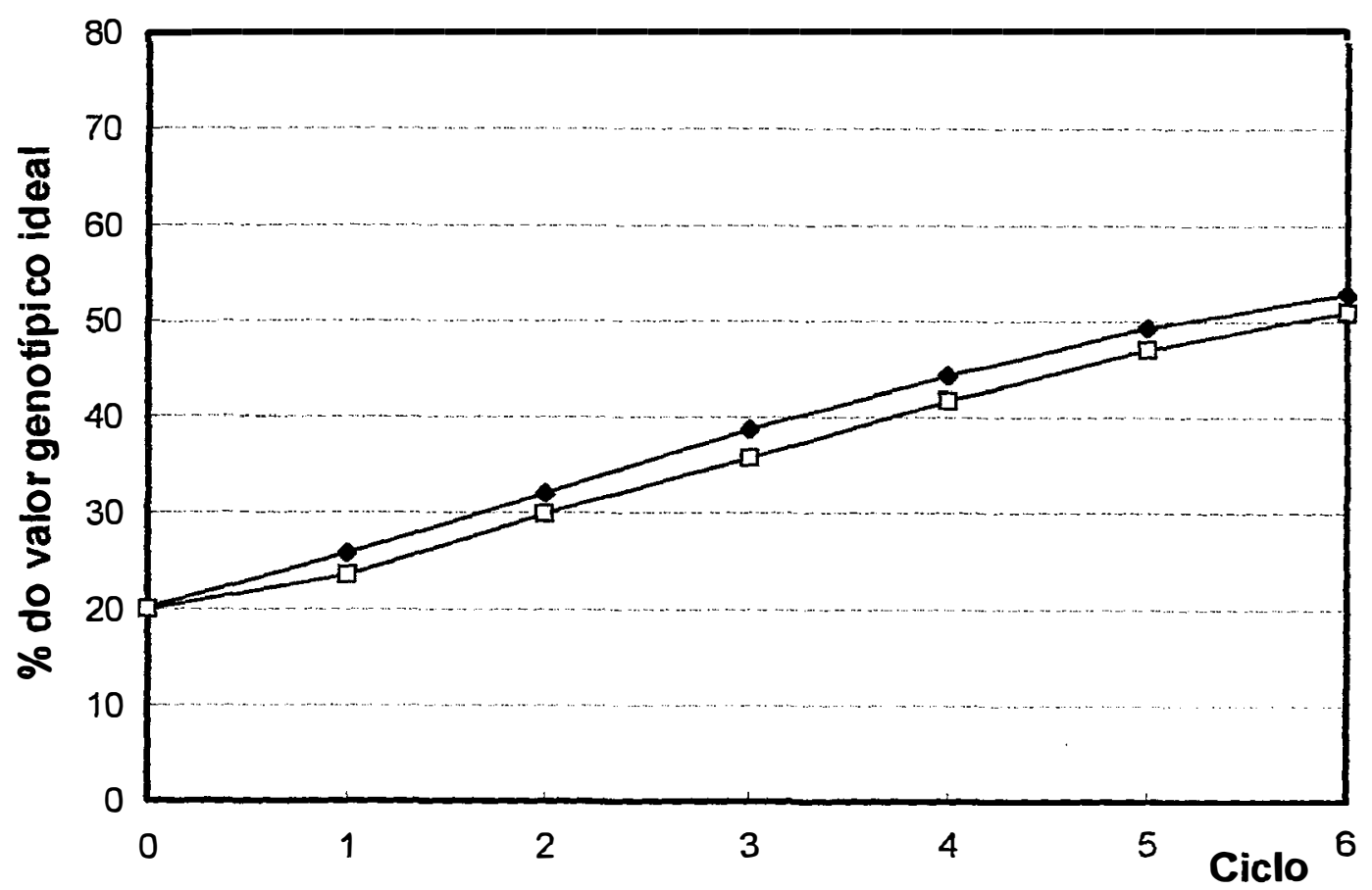

Figura 23. Respostas com a seleção assistida por marcadores $(\nabla)$ e com a seleção baseada na média fenotípica de progênies ( $\square$ ), expressas em porcentagem do valor genotípico ideal (alelos favoráveis fixados em todos os locos), na simulação de 6 ciclos seletivos em computador, admitindo herdabilidade entre plantas $S_{0}$ igual a 0,025 , sistema precoce de obtenção de progênies, ausência de dominância, proporção de progênies selecionadas por ciclo igual a $0,25 \%$ e com o coeficiente de heterogeneidade de solo de Smith (1938) igual a 0,2. 


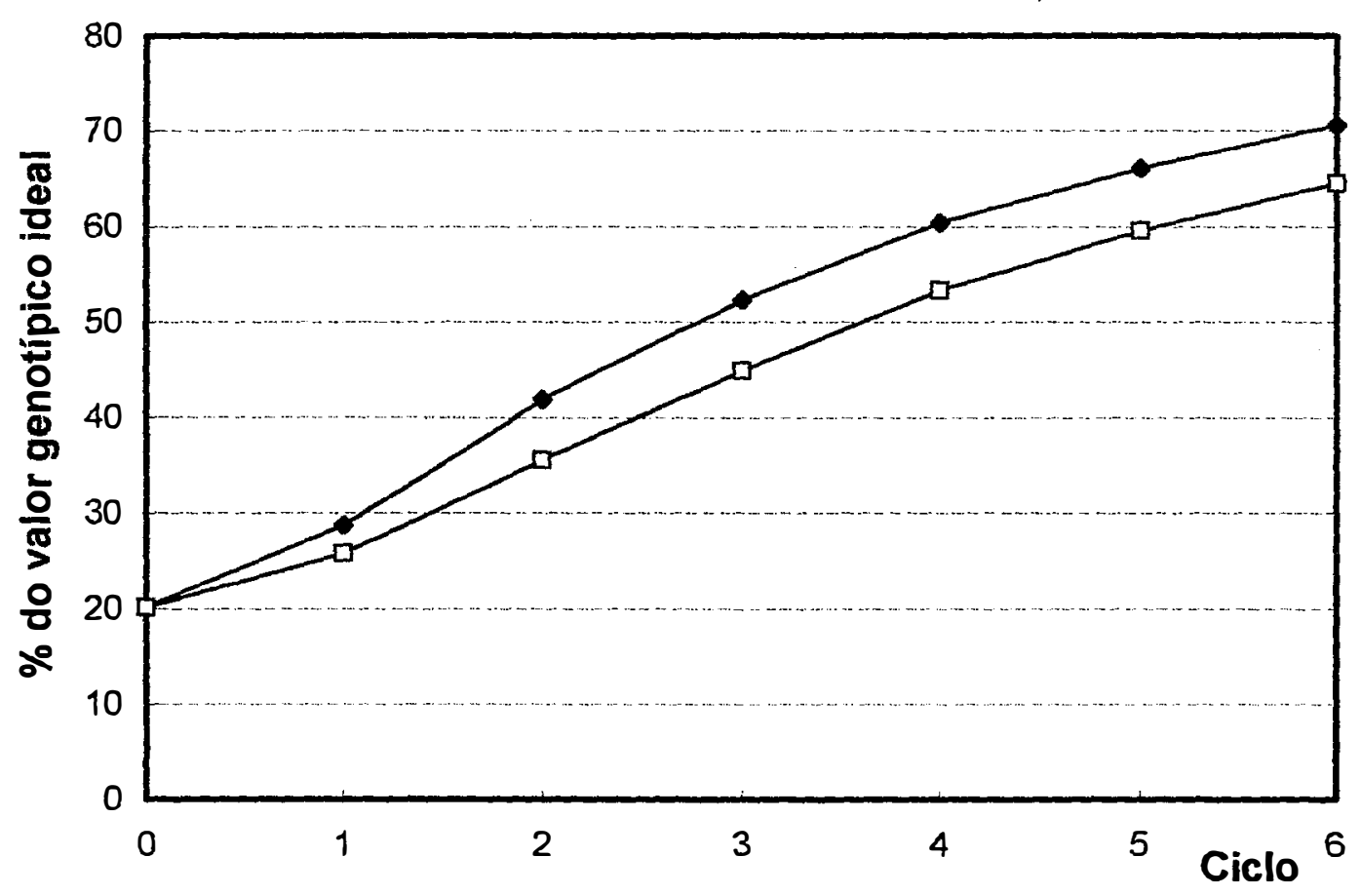

Figura 24. Respostas com a seleção assistida por marcadores $(\bullet)$ e com a seleção baseada na média fenotípica de progênies ( $\square$ ), expressas em porcentagem do valor genotípico ideal (alelos favoráveis fixados em todos os locos), na simulação de 6 ciclos seletivos em computador, admitindo herdabilidade entre plantas $S_{0}$ igual a 0,025 , sistema precoce de obtenção de progênies, ausência de dominância, proporção de progênies selecionadas por ciclo igual a 0,25\% e com o coeficiente de heterogeneidade de solo de Smith (1938) igual a 0,8. 


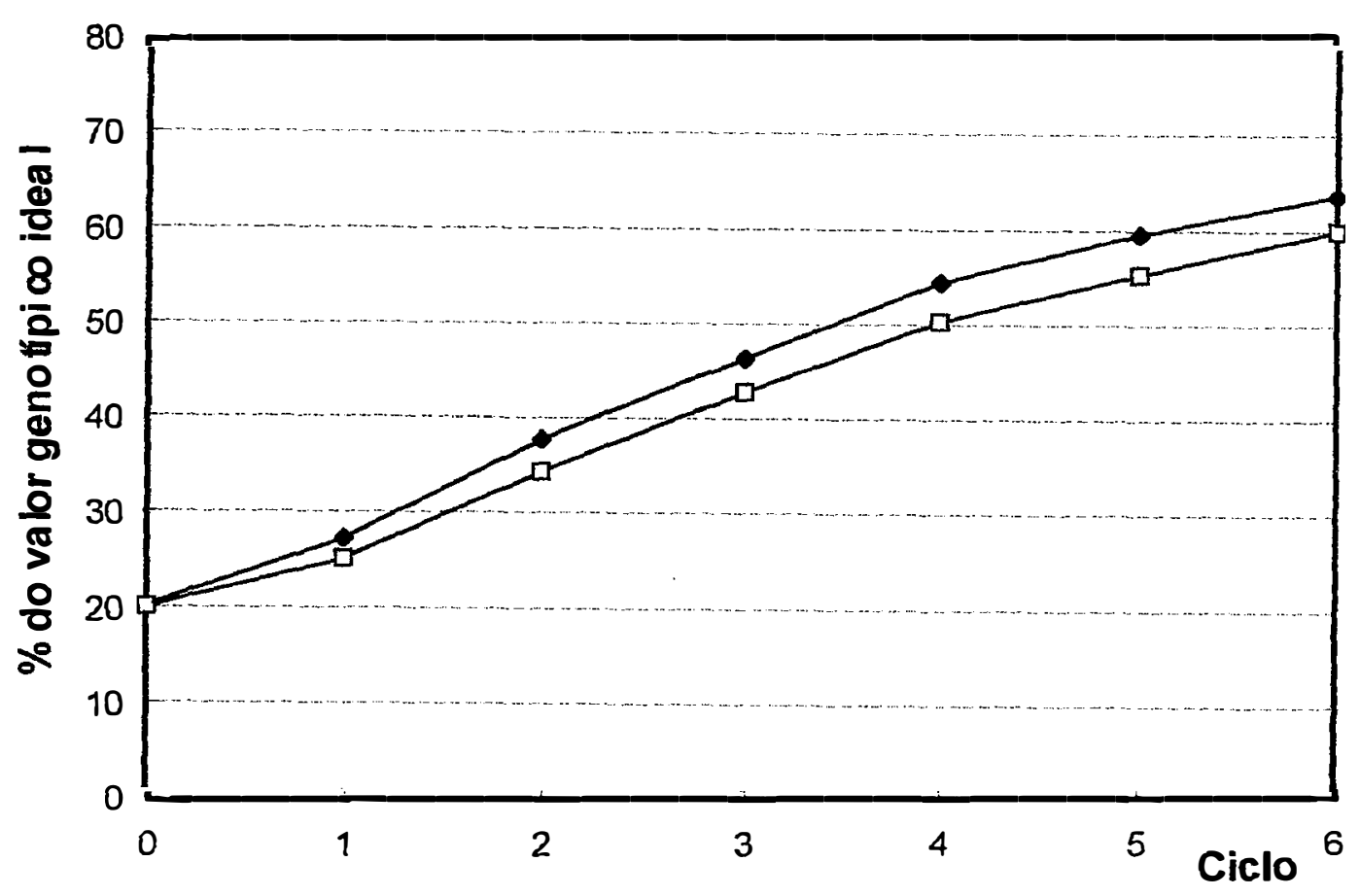

Figura 25. Respostas com a seleção assistida por marcadores $(\nabla)$ e com a seleção baseada na média fenotípica de progênies ( $\square$ ), expressas em porcentagem do valor genotípico ideal (alelos favoráveis fixados em todos os locos), na simulação de 6 ciclos seletivos em computador, admitindo herdabilidade entre plantas $S_{0}$ igual a 0,025 , sistema precoce de obtenção de progênies, ausência de dominância, proporção de progênies selecionadas por ciclo igual a 0,25\% e com um total de locos marcadores igual a 200. 


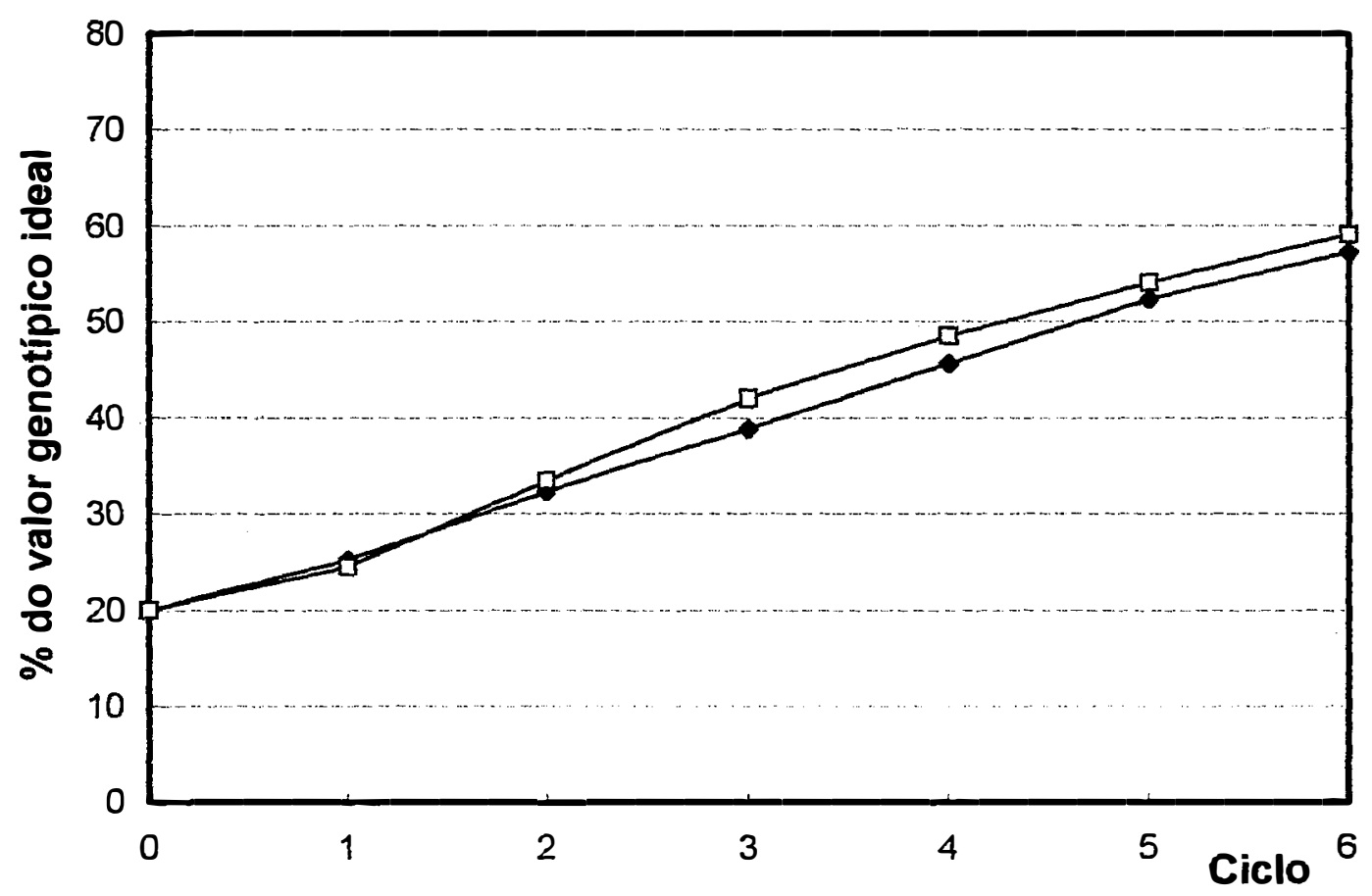

Figura 26. 'Respostas com a seleção assistida por marcadores ( ) e com a seleção baseada na média fenotípica de progênies ( $\square$ ), expressas em porcentagem do valor genotípico ideal (alelos favoráveis fixados em todos os locos), na simulação de 6 ciclos seletivos em computador, admitindo herdabilidade entre plantas $S_{0}$ igual a 0,025 , sistema precoce de obtenção de progênies, ausência de dominância, proporção de progênies selecionadas por ciclo igual a 0,25\% e com um total de locos marcadores igual a 30. 


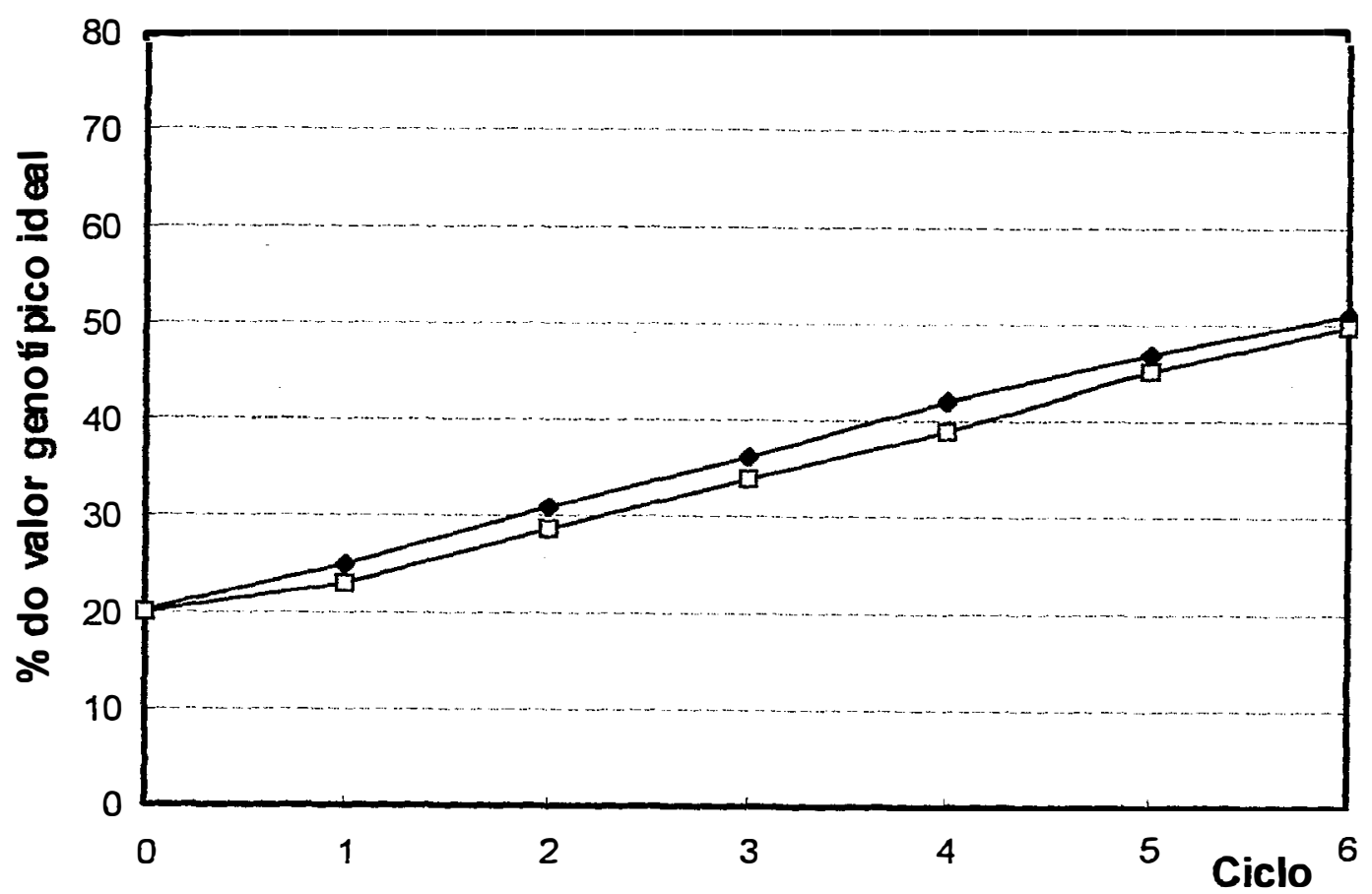

Figura 27. Respostas com a seleção assistida por marcadores ( $)$ e com a seleção baseada na média fenotípica de progênies ( $\square$ ), expressas em porcentagem do valor genotípico ideal (alelos favoráveis fixados em todos os locos), na simulação de 6 ciclos seletivos em computador, admitindo herdabilidade entre plantas $S_{0}$ igual a 0,025 , sistema precoce de obtenção de progênies, ausência de dominância, proporçảo de progênies selecionadas por ciclo igual a 0,25\% e com a utilização de 20 linhagens para formar a população-base. 